Andrews University

Digital Commons @ Andrews University

1983

\title{
An Assessment of the Perceived Inservice Needs of K-12 Teachers of the Lake Union Conference of Seventh-day Adventists
}

Hazel R. Wright

Andrews University

Follow this and additional works at: https://digitalcommons.andrews.edu/dissertations

Part of the Teacher Education and Professional Development Commons

\section{Recommended Citation}

Wright, Hazel R., "An Assessment of the Perceived Inservice Needs of K-12 Teachers of the Lake Union Conference of Seventh-day Adventists" (1983). Dissertations. 1563.

https://digitalcommons.andrews.edu/dissertations/1563

https://dx.doi.org/10.32597/dissertations/1563

This Dissertation is brought to you for free and open access by the Graduate Research at Digital Commons @ Andrews University. It has been accepted for inclusion in Dissertations by an authorized administrator of Digital Commons@ Andrews University. For more information, please contact repository@andrews.edu. 


\section{Andrews \$university}

Seek Knowledge. Affirm Faith. Change the World.

Thank you for your interest in the

\section{Andrews University Digital Library of Dissertations and Theses.}

Please honor the copyright of this document by not duplicating or distributing additional copies in any form without the author's express written permission. Thanks for your cooperation. 


\section{INFORMATION TO USERS}

This reproduction was made from a copy of a document sent to us for microtilming. While the most advanced technology has been used to photograph and reproduce this document. the quality of the reproduction is heavily dependent upon the quality of the material submitted.

The following explanation of techniques is provided to help clarify markings or notations which may appear on this reproduction.

1. The sign or "target" for pages apparently lacking from the documer : photographed is "Missing Page(s)". If it was possible to obtain the missing page(s) or section, they are spliced in to the film alnng witi، adjacent pages. This may have necessitated cutting through an image and duplicating adjacent pages to assure complete continuity.

2. When an image on the film is obliterated with a round black mark, it is an indication of either blurred copy because of movement during exposure. duplicate copy. or copyrighted materials that should not have been rilmed. For blurred pages. a good image of the page can be found in the adjacent frame. If copyrighted materials were deleted. a target note will appear listing the pages in the adjacent frame.

3. When a map, drawing or chart. etc., is part of the material being photographed. a detinite method of "sectioning" the material has been followed. It is customary to begin filming at the upper ieft hand comer of a large sheet and to continue from left to right in equal sections with small overlaps. If necessary. sectioning is continued again-beginning below the first row and continuing on until complete.

4. For illustrations that cannot be satisfactorily reproduced by xerographic means. photographic prints can be purchased at additional cost and inserted in to your xerographic copy. These prints are available upon request from the Dissertations Customer Services Department.

5. Some pages in any document may have indistinct print. In all cases the best available copy has been filmed.

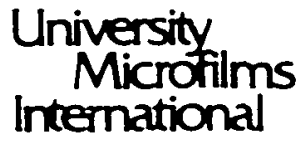

300 N. Zeeo Road

Ann Arbor. MI 48106 
Reproduced with permission of the copyright owner. Further reproduction prohibited without permission. 
Wright, Hazel Ruth Garner

AN ASSESSMENT OF THE PERCEIVED INSERVICE NEEDS OF K-12 TEACHERS OF THE LAKE UNION CONFERENCE OF SEVENTH.DAY ADVENTISTS

Andrews University

ED.D. 1983

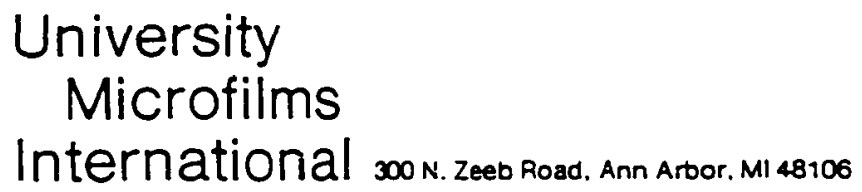

Copyright 1984

by

Wright, Hazel Ruth Garner

All Rights Reserved 
Reproduced with permission of the copyright owner. Further reproduction prohibited without permission. 
in all cases this material has been filmed in the best possible way from the availatle copy.

Problems encountered with this document have been identified here with a check mark

1. Glossy photographs or pages

2. Colored illustrations, paper or print

3. Photographs with dark background

4. Illustrations are poor copy

5. Pages with black marks, not original copy

6. Print shows through as there is text on both sides of page

7. Indistinct. broken or small print on several pages

8. Print exceeds margin requirements

9. Tightly bound copy with print lost in spine

10. Computer printout pages with indistinct print

11. Fage(s) lacking when material received, and not available from school or author.

12. Page(s) seem to be missing in numbering only as text follows.

13. Two pages numbered . Text follows.

14. Curling and wrinkled pages

15. Other

\section{University Microfilms International}


Reproduced with permission of the copyright owner. Further reproduction prohibited without permission. 


\begin{abstract}
Andrews University
School of Graduate Studies

AN ASSESSMENT OF THE PERCEIVED INSERVICE NEEDS

OF $\mathrm{K}-12$ TEACHERS OF THE LAKE UNION

CONFERENCE OF SEVENTH-DAY ADVENTISTS
\end{abstract}

\author{
A Dissertation \\ Presented in Partial Fulfillment \\ of the Requirements for the Degree \\ Doctor of Education
}

by

Hazel R. Garner Wright

August 1983 


\title{
AN ASSESSMENT OF THE PERCEIVED IN-SERVICE NEEDS OF $K-12$ TEACHERS OF THE LAKE UNION CONFERENCE OF SEVENTH-DAY ADVENTISTS
}

\author{
A dissertation \\ presented in partial fulfillment \\ of the requirements for the degree \\ Doctor of Education
}

by

Hazel R. Garner Wright

APPROVAL BY THE COMMITTEE:

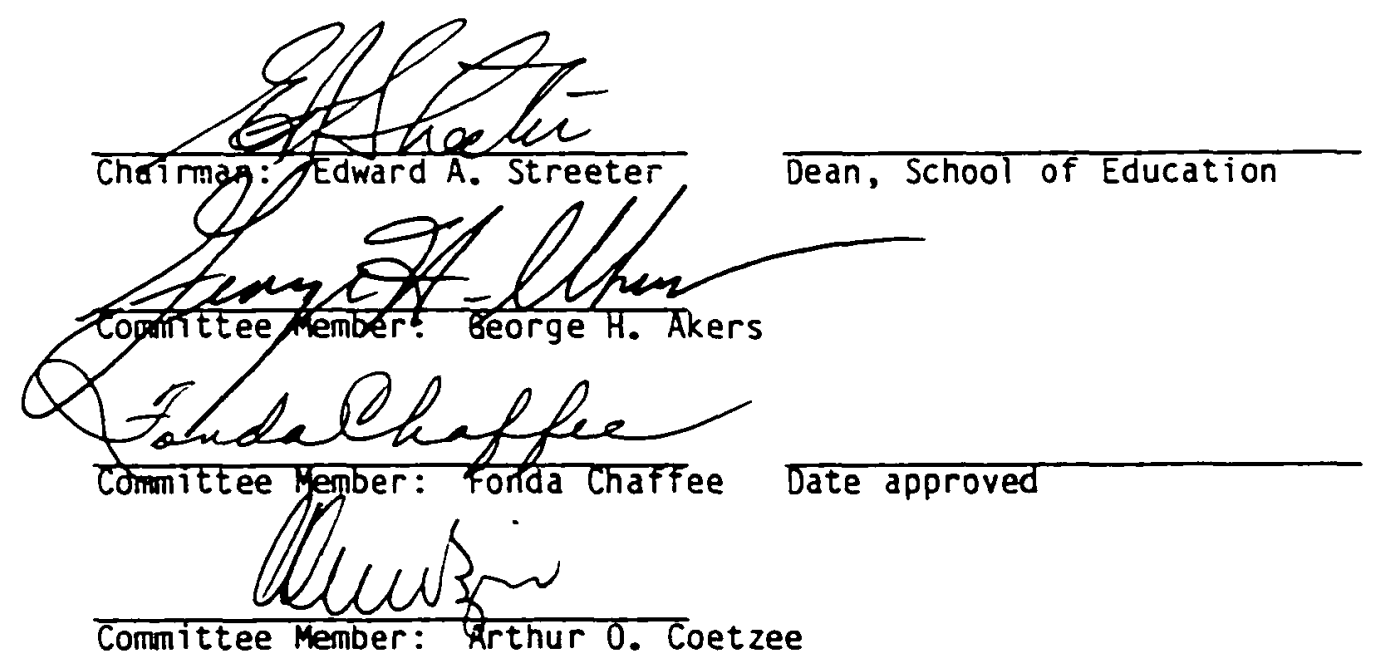

External Examiner: Frederick R. Stephan 
TABLE OF CONTENTS

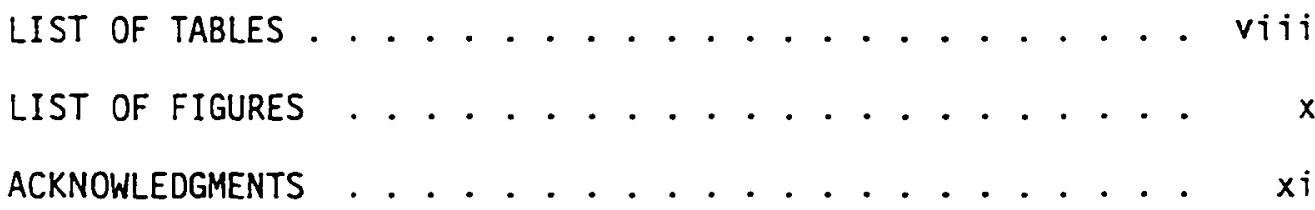

Chapter

I. INTRODUCTION ............................ I

Background--Inservice Education ......... 1

Statement of the Problem ........... . 7

Purpose of the Study . . . . . . . . . . . . 7

Importance of the Study ............. . 8

Basic Assumptions ................ . . 10

Delimitations of the Study. . . . . . . . . . 11

Limitations of the Study............ 11

Definition of Terms ............... 11

Organization of the Study .......... 12

II. REVIEW OF THE RELATED LITERATURE . . . . . . . . . . . 14

Introduction .................. 14

Historical Overview on Inservice Education..... 14

Substitutions for College Education . . . . . 15

Degree Completion and Sumer Schools...... 15

Certification ................ . . 15

Sputnik Era--Science and Mathematics Emphasis . . 16

The Seventies and Reexamination of

Inservice Training............. 16

Purposes of Inservice Education ... . . . . . . . 17

Updating, Continuation, and

Completion of Formal Education ........ . 17

Student Performance and Teaching Improvement . . . 18

Problem-Solving Orientation .......... . 19

Salary Improvement . . . . . . . . . . . 20

Morale Building . . . . . . . . . . . . 20

Socialization ............ . . . 20

Characteristics of Successful and

Unsuccessful Inservice Programs . . . . . . . 21

Successful Programs ............... . 21

Inservice for both Teachers and Administrators . 22

Needs Assessment of Community, Curriculum,

and Staff ............. 23 
Chapter

II. (Continued)

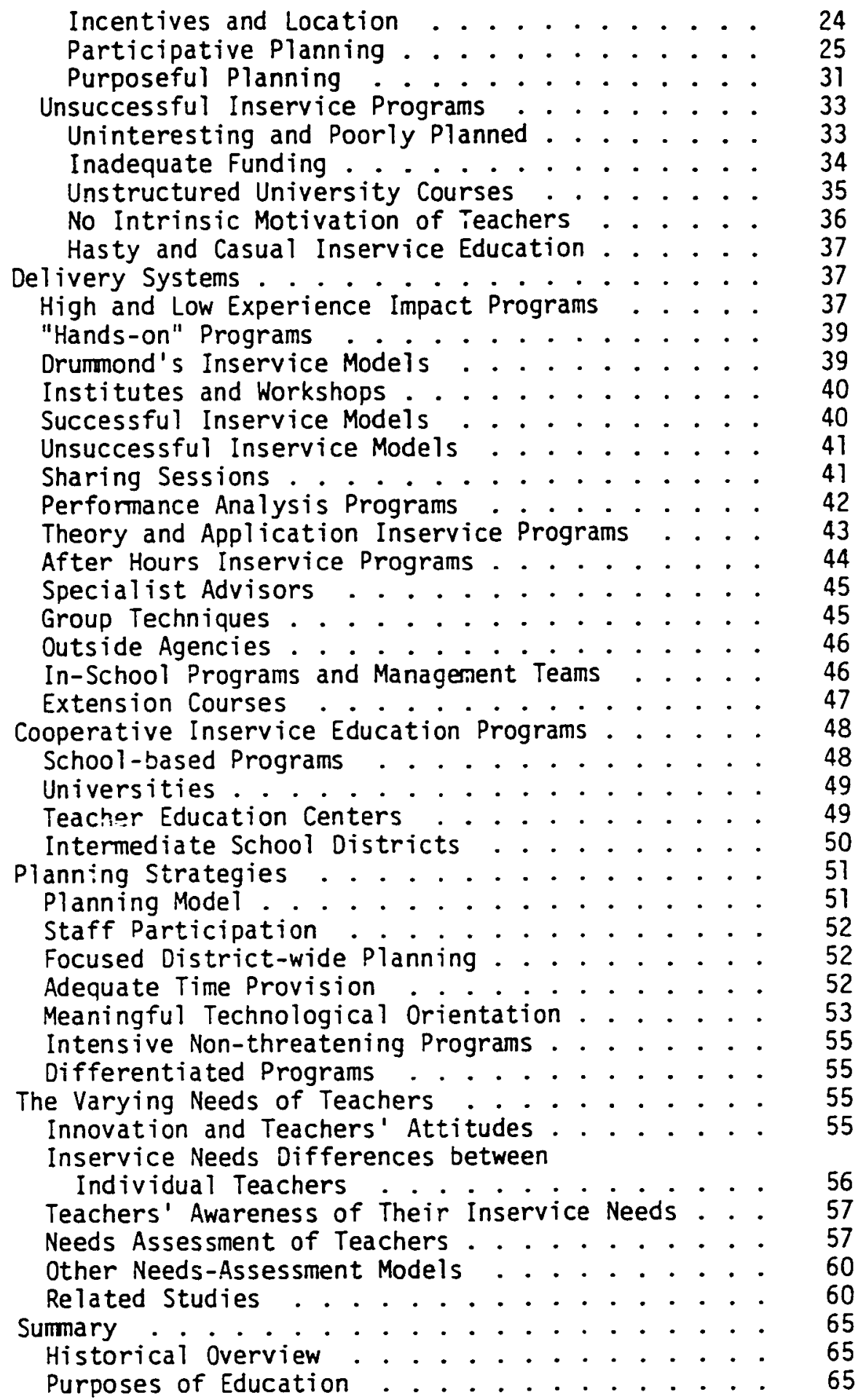


Chapter

II. (Continued)

Characteristics of Successful and Unsuccessful Inservice Programs ....... 65

Delivery Systems ............... 66

Cooperative Inservice Programs . . . . . . . 66

Planning Strategies ............ . 67

Varying Needs of Teachers ......... 67

III. RESEARCH DESIGN AND METHODOLOGY OF THE STUDY . . . . 68

The Sample................. 68

Description of the Instrument ......... 70

The Lake Union Conference Inservice

Assessment (LUCIA) . . . . . . . . . 70

Validation of the Lake Union Inservice

Assessment (LUCIA) . . . . . . . . . 76

Data Gathering Procedures . . . . . . . . 78

Data Analysis ............. . . 79

IV. PRESENTATION AND ANALYSIS OF THE DATA . . . . . . 82

The Findings . . . . . . . . . . . . 82

Description of the Data .......... 83

Item and Ranked Categories for All $\mathrm{K}-12$

Elementary and Secondary Teachers . . . . . 83

Ranked Items--k-12 Teachers .......... 83

Ranked Categories-All K-12 Teachers....... 90

Ranked Items--Elementary Teachers . . . . . . 98

Ranked Categories--Elementary Teachers . . . . 105

Ranked Items--Secondary Teachers ........ . 114

Ranked Categories--Secondary Teachers . . . . . 121

Summary--K-12, Elementary and Secondary

Teachers Perceived Needs....... . . . 129

Ranked Categories of Elementary Teachers

by Teaching Assignment . . . . . . . . . 130

Ranked Categories of K-2 Elementary Teachers... 130

Ranked Categories of 3-5 Elementary Teachers . . . 137

Ranked Categories of 6-8 Elementary Teachers . . . 143

Summary--Elementary Teachers by Teaching

Ass ignment . . . . . . . . . . . . . 149

Elementary Teachers by Years of Experience . . . . 151

Ranked Categories of Elementary Teachers

with $0-5$ Years of Experience........ 151

Ranked Categories of Elementary Teachers with 6-10 Years of Experience . . . . . . 157

Ranked Categories of El ementary Teachers

with 11-15 Years of Experience........ 163

Ranked Categories of Elementary Teachers

with 16-20 Years of Experience ........ 169 
Chapter

IV. (Continued)

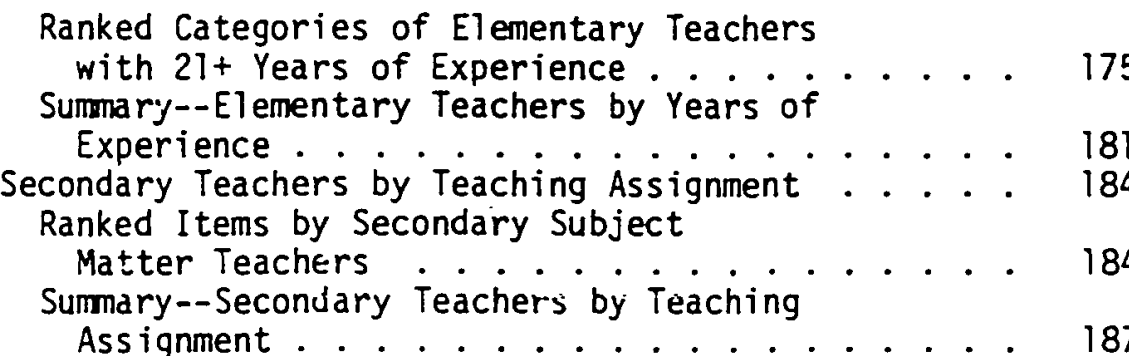

Ranked Categories of Secondary Teachers

by Years of Experience ... . . . . . . . . 189

Ranked Categories of Secondary Teachers with $0-5$ Years of Experience ........ . 189

Ranked Categories of Secondary Teachers with 6-10 Years of Experience ........ . 195

Ranked Categories of Secondary Teachers with 11-15 Years of Experience . . . . . . . . . 201

Ranked Categories of Secondary Teachers with 16-20 Years of Experience . . . . . . . . 207

Ranked Categories of Secondary Teachers with $21+$ Years of Experience . . . . . . . 213

Summary of Secondary Teachers by Years of Experience .............. . 219

Combination of Teaching Assignments . . . . . . 221

Ranked Categories of Elementary Teachers Who Had Taught Three of Fewer Grades . . . . . . 221

Ranked Categories of Elementary Teachers Who Had Taught More than Three Grades . . . . . 227

Ranked Categories of Teachers who Taught Both Elementary and Secondary ....... . 233

Ranked Categories of Principals Who Also Served as Teachers ........... 238

Summary--Perceived Needs of Teachers with a
Combination of Teaching Assignments . . . . 243
..

Summary--Perceived Needs of Teachers with a
Combination of Teaching Assignments . . . . . . . . . . . . . . 243
Summary . . . . . . . . .

V. SUMMARY, CONCLUSIONS, AND RECOMMENDATIONS . . . . 248

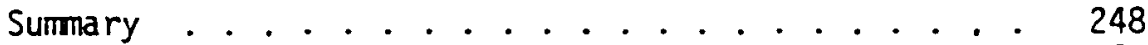

Conclusions .. . . . . . . . . . . . . . 259

Recommendations ............ . . 266

APPENDICES .......................... 269

A. Lake Union Conference Inservice Assessment Instrument 270

B. Permission Letter from Lake Union Conference

Education Department ............. . 275

C. Introductory Letter for A1I Elementary Teachers . . . 277

vi 
APPENDICES (Continued)

D. Introductory Letter to Lake Region

Conference Teachers . . . . . . . . . . . . . . 279

E. Letter to Educational Superintendent of

the Lake Region Conference . . . . . . . . . . 281

F. Reminder Letter to Lake Region Conference Teachers . . 283

G. Raw Data Responses from K-12 Teachers . . . . . . 285

BIBLIOGRAPHY . . . . . . . . . . . . . . . . 290

vii 


\section{LIST OF TABLES}

1. Experience Impact of Activities . . . . . . . . . . 38

2. Ranked Items for AII K-12 Teachers . . . . . . . . . 84

3. Ranked Categories for $\mathrm{All} \mathrm{K}-12$ Lake Union

Conference Teachers . . . . . . . . . . . . 91

4. A Summary of the Ranked Categories for $A 11 \mathrm{~K}-12$ :

5. Ranked Items for All Elementary Lake Union Conference Teachers . . . . . . . . . . . . . 99

6. Ranked Categories for All Elementary Lake Union Conference Teachers . . . . . . . . . . 106

7. A Summary of the Ranked Categories for All Elementary Lake Uilion Conference Teachers . . . . . 110

8. Ranked Items for All Secondary Lake Union Conference Teachers . . . . . . . . . . . 115

9. Ranked Categories of All Secondary Lake Union Conference Teachers . . . . . . . . . . 122

10. A Summary of Ranked Categories for All Secondary Lake Union Conference Teachers . . . . . . 126

11. A Comparison of Ranked Categories for All K-12, Elementary, and Secondary Teachers . . . . . . 130

12. A Summary of Ranked Categories of K-2 Elementary Lake Union Conference Teachers ......... 132

13. A Summary of Ranked Categories of 3-5 Elementary Lake Union Conference Teachers . . . . . . . . 138

14. A Summary of Ranked Categories of 6-8 Elementary Lake Union Conference Teachers .. . . . . . . . 144

15. A Comparison of Ranked Categories of $k-2,3-5$, 6-8 Teachers and AlI El ementary Teachers by Teaching Assignment . . . . . . . . . . 151

16. A Summary of the Ranked Categories of Elementary Teachers with $0-5$ Years of Experience....... 152

17. A Summary of Ranked Categories of Lake Union Conference Elementary Teachers with 6-10 Years of Experience . . . . . . . . . . . 158

18. A Summary of Ranked Categories of Lake Union Conference Elementary Teachers with $11-15$ Years of Experience............... 164

19. A Sumary of Ranked Categories of Lake Union Conference Elementary Teachers with 16-20 Years of Experience . . . . . . . . . . . . 170

20. A Sumary of the Ranked Categories of Elementary Teachers with $21+$ Years of Experience...... 176 
21. A Comparison of Ranked Categories of All

Elementary Teachers and Elementary Teachers

Who Had Taught $0-5,6-10,11-15,16-20$, and

$21+$ Years ................. 183

22. Top Six Items as Ranked by Secondary Subject

Teachers ................. 186

23. A Comparison of Ranked Categories of Secondarv

Subject Matter Teachers . . . . . . . . . . . . . 188

24. A Summary of Ranked Categories of Secondary

Teachers Who Had Taught 0-5 Years . . . . . . . . 190

25. A Summary of Ranked Categories of the Lake Union

Conference Secondary Teachers Who Taught

6-10 Years ..............

26. A Summary of Ranked Categories of Lake Union

Conference Secondary Teachers Who Had

Taught 11-15 Years .............. 202

27. A Summary of Ranked Categories of Lake Union

Conference Secondary Teachers Who Had

Taught 16-20 Years . . . . . . . . . . . 208

28. A Summary of Ranked Categories of Lake Union

Conference Secondary Teachers Who Had

Taught $21+$ Years - $\cdot \cdot \cdot \cdot \cdot \cdot \cdot \cdot \cdot i l$

29. A Comparison of Ranked Categories of All

Secondary and Secondary Teachers Who Had Taught $0-5,6-10,11-15,16-20$, and

$21+$ Years................. . .

30. A Summary of Ranked Categories of Lake Union

Conference Elementary Teachers Who Teach

Three or Less Grades . . . . . . . . . .

31. A Summary of Ranked Categories of Lake Union Conference Elementary Teachers Who Teach

More than Three Grades - $\cdot \cdot \cdot \cdot \cdot \cdot \cdot$

32. A Summary of Ranked Categories of Lake Union Conference Teachers Who Teach Both Elementary and Secondary Grades .............. 234

33. A Summary of Ranked Categories of Lake Union Conference Principals Who Also Serve as Teachers . . 239

34. A Comparison of Ranked Categories of All K-12 Teachers and Teachers with a Combination of

Teaching Assignments 


\section{LIST OF FIGURES}

1. The Geographical Area Referred to as the Lake Union Conference of Seventh-day Adventists ..... 69

2. Teachers Employed by Individual Conferences of the Lake Union Conference for the School Year 1982-83 .............. . 71

3. Comparison of the Ranked Categories for All K-12, Elementary, and Secondary Teachers....... 131

4. Comparison of the Ranked Categories of the $K-2,3-5,6-8$ Teachers, and All Elementary Teachers by Teaching Assignment .......... 150

5. Comparison of the Ranked Categories of All Elementary Teachers and Elementary Teachers Who Had Taught $0-5,6-10,11-15,16-20$, and $21+$ Years ............... 182

6. Comparison of the Ranked Categories of All Secondary Teachers and Secondary Teachers Who Had Taught $0-5,6-10,11-15,16-20$, and $21+$ Years ............... 220

7. Comparison of the Ranked Categories of Teachers Who Had a Combination of Teaching Assignments 


\section{ACKNOWLEDGEMENTS}

Any student who completes a doctoral program must have a patient, understanding, knowledgeable, and encouraging chairperson and committee. For the writer, Dr. Edward Streeter, Dr. George Akers, Dr. Fonda Chaffee, and Dr. Arthur Coetzee have admirably been the supporting cast that helped to bring the study and the total program to fruition. Their expertise and encouragement have been greatly appreciated.

Special accolades go to the Lake Union Conference, Warren Minder and his staff, and the conference educational superintendents for their cooperation and support during the study. A special note of appreciation goes to the teachers of the Lake Union Conference for their assistance in the survey.

The untiring and unending support of my husband, Wayne, has always been the catalyst that helped me to reach my goal. His patience and longsuffering is greatly appreciated and esteemed. I am eternally grateful for his support. A special note of thanks to my family for their encouragement and love.

For all who have contributed to bringing this dissertation to completion, I want to express my sincere appreciation. 


\section{ABSTRACT}

\section{AN ASSESSMENT OF THE PERCEIVED INSERVICE NEEDS \\ OF $K-12$ TEACHERS OF THE LAKE UNION \\ CONFERENCE OF SEVENTH-DAY \\ ADVENTISTS}

by

Hazel R. Garner Wright

Chairman: Edward A. Streeter, Ed.D. 


\section{ABSTRACT OF GRADUATE STUDENT RESEARCH \\ Dissertation}

Andrews University

Department of Education

Title: AN ASSESSMENT OF THE PERCEIVED INSERVICE NEEDS OF K-12 TEACHERS OF THE LAKE UNION CONFERENCE OF SEVENTH-DAY ADVENTISTS

Name of researcher: Hazel R. Garner Wright

Name and title of faculty advisor: Edward A. Streeter, Ed.D.

Date completed: June 1983

\section{Problem}

While an active and costly inservice program exists for teachers of the Lake Union Conference, there appears to be no data on the perceived inservice needs of these teachers. Consequently, there is a need to identify their perceived inservice educational needs for purpose of enhancement and strengthening the existing program. The present study attempts to identify the perceived inservice needs of the $k-12$ teachers of the lake Union Conference currently employed within its educational system. 


\section{Method}

Data was gathered by using the "Lake Union Conference Inservice Assessment" which was a modified version of Ingersoll's Teacher Needs Assessment Survey modified to incorporate the unique place of religion in the curriculum under study. Responses for each item on the Likert-type scale were weighted giving strongly disagree--1, disagree--2, undecided--3, agree--4, and strongly agree--5. Items were ranked using weighted scores. Nine categories were ranked according to the mean of the weighted score, while each item within the category was ranked. Teachers were analyzed as a $\mathrm{K}-12$ group, divided into elementary and secondary, further divided by years of experience and teaching assignment.

\section{Results}

Responses indicated similar perceived inservice needs, such as integrating the religious concepts into the curriculum, making it applicable to everyday life, motivating and instilling in the student the will to learn on his own. On the other hand, distinct differences were observed such as secondary teachers perceived a greater need for discipl ine and teaching techniques, whereas, the elementary teachers had a greater need for implementing and supervising individualizing instruction and developing better communication with parents and students.

\section{Conclusions}

The $K-12$ teachers of the Lake Union Conference were cognizant of their responsibility in the development of religious and moral values. It appears the teachers were more concerned about the 
development of the students in their classroom than their own personal development. Years of experience and teaching assignment had a direct affect on the teachers' perceived inservice needs. 
CHAPTER I

INTRODUCTION

\section{Background--Inservice Education}

The matter of inservice education for teachers should play

a central role in the thinking of educators generally and educa-

tional administrators in particular. An example of such thinking

is found in the following definition of inservice education as

given by the National Commission on Teacher Education and Profes-

sional Standards:

. . that growth which takes place after the teacher is

on the job. It is a continuation of the professional

development which was begun during the preservice period

of preparation. Inservice education is a process inherent

in any planned program designed to make the individual a

more effective teacher. (Edmonds, 1966, p. 8, Emphas is supplied)

One of the important commodities dealt with in education, ramely, factual information in both the learning process and the value of the course content to be taught, is continually undergoing updating and enlargement at an unbelievable rate, therefore, one can readily agree with a definition that places inservice education and updating at the heart of effective teaching.

While the centrality of the role of inservice education has seen limited alteration, the modes and foci of inservice education have seen considerable fluctuation. Prior to World War I, inservice 
education was held in the normal schools of that day during summer sessions. When the certification requirements of the 1930 s made it necessary for all teachers to hold bachelor's degrees, the focus of inservice education took on the form of remediation for making up degree deficits. Prall and Cushman conducted an extensive study of educational practices during 1944 and pointed up the need for inservice education to stretch beyond mere remediation to the development of teachers and the broadening of their understanding of the learning process itself.

During the period between World War II to the mid-1950s inservice education again made an effort to assist in certification requirements (Tyler, 1971). The increased birth rate called for additional certified personnel to teach the burgeoning school-age population.

The advent of Sputnik in 1957 shocked America into the realization that the Russian educational system had somehow yielded better space scientists than the American system. This realization in turn served as a stimulus to find ways and means of producing a superior educational product to what had previously originated in America. Scientists and educators alike collaborated to evaluate and imporve the educational scene. As a result of the research conducted, curriculum guidelines and frameworks were established to assist the teacher to teach the required facts. The advent of the new mathematics, science innovations, and audio-visual technology of the time pointed up the dire necessity for retraining teachers for the new content and methodology needed (Tyler, 1971). 
The post-Sputnik era provided renewal of both course content and teacher effectiveness.

The post-Sputnik era brought with it greater awareness for the value of inservice education and a popularizing of that prac.tice, educators of the 1970 s began with a fundamental review of: the nature, value purposes, planning strategies, and modes of inservice education. Sportsman (1981, p. 307) felt that traditiona)ly inservice education had been nothing more "than a hastily prepared, ineptly presented, and educationally stultifying" event. Others like Rubin (1978, p. 8) agreed that "the legacy of inser.. vice education was characterized by randomness and fragmentation, by programs that deferred to expediency rather than need, and methodologies that were largely outdated."

This was a continuation of the analysis started in the 1960 s when educators who noticed deficiencies in the inservice education process began to suggest new solutions. Moffit (1963) saw that schools were facing different kinds of issues than they had previously met strongly recommended that schools now become involved in the inservice educational process itself.

Up to this time the content and mode of inservice training had been determined by forces and considerations outside of the input of those who were directly involved in the actual teaching process. The need for teacher participation in all phases of inservice education was beginning to be recognized as of value. Mauth (1962) maintained that 
- . success of inservice program is directly proportionate to acceptance of its goals by participants. . . . Perhaps the surest way to avoid abuse of this principle of learning is to start an inservice education program with direct and immediate concerns of the staff. These concerns cannot be surmised but must be defined in direct consultation with the teachers themselves. ( $p .15$ )

Throughout the literature of the 1960 s, one could readily detect the growing emphasis on teacher participation in planning the inservice educational program. Teachers were not motivated by the programs which had been provided up to this time (Johnson \& Johnson, 1980). Roberts (1964, p. 17) surfaced the problem like this: "Too often, decisions in such matters as inservice education were made for teachers as though someone else knew best the problems with which teachers needed help." While the need for participative planning by teachers became obvious, no planning models existed, nor did there appear to be enough experimental data to support the growing notion that participative planning was to be preferred. Harris and Bessent (1969) voiced their concern over the limited research which was being conducted in the area of inservice education as well as the lack of case studies and objective descriptions of inservice programing. Gradually, educators began to fit the earlier findings of psychology into the framework of inservice training. The importance of "starting" an inservice program with perceived needs of teachers can be substantiated by basic learning theory. Bugelski (1956) wrote:

- . learning proceeds most effectively and tends to be most permanent when the learner is motivated that is, when he has a stake, as it were, in the activity being undertaken. (p. 452)

Bigge (1964) now concurred with Bugelski (1956) by stating 
- . that motivation to learn is produced if a person develops a state of tension resulting from unsatisfied needs. . . . The person's aims becomes a reduction of tension, which can occur only as the need is whole or partially satisfied. Therefore when an individual is expected to be motivated to the point of participating in an inservice program the person must feel that some need is being met. (p. 1891)

For any inservice program to be successful, it seems, then, the participating teacher should perceive and identify a need for a particular skill then motivation toward participation in an inservice program can take place. It was felt that this could best be achieved when a teacher participates in the inservice planning process. This call for teacher participation in planning inservice educational programs continued into the 1970s. Brimm and Tollett (1974) reflected the tone of the decade by the following:

. . . determination of the needs of the teachers within the school system seems prerequisite to the planning of meaningful inservice programs. Too often, the membership of inservice planning committees is composed largely of school administrators.

Finally, if teachers' professional growth is to be taken seriously, school administrators and teachers must pool their knowledge and resources and seek to make inservice education more responsive to the needs and interests of practicing classroom teachers. (p. 525)

Aaron (1965, p. 5), and Edmond (1963, p. 8) maintained that "the initial step in the inservice programing is to be the identification of the needs of the participants. Inservice activities should then be planned based upon those needs." Harris (1969) advocated inservice programs should be planned around the needs of the individuals participating in the activities. Moburg (1972) stated: 
Any successful program must be geared to the present needs of teachers. Research should be conducted which compares the self-perceived instructional needs of teachers with a needs assessment obtained through direct observation, personal interviews, unobtrusive or reactive measures. Research should be conducted which assesses the needs of teachers and bases the inservice program directly upon those needs. ( $p .36$ )

Moburg (1972) wrote about conducting inservice programs in reading based on needs assessment and on surveys conducted by Adams (1964), Austin and Morrison (1963), and Smith, Otto, and Harty (1970) were based on teachers' needs. Unfortunately, results of the surveys were not reported in the literature.

Adams (1964) stated that teachers should be involved "in decisions about the content of the inservice through some medium, and the programs should be based on the perceived needs of the teachers" (p. 32).

Mills (1962) examined inservice education programs, and determined that inservice, to be effective, "needs to be planned intelligently. This planning required a critical assessment of the personnel which were involved, determining the types of programs, means and method of providing for such" (p. 52).

Ingersoll, aware of this need to include the teacher in the decision-making process for effective inservice education, in the absence of an existing instrument, developed in 1975 an assessment instrument himself which "would provide reliable and convenient format through which a variety of school systems could gather data on perceived inservice needs, using that data to plan inservice programs" (1978, p. 1). Ingersoll successfully field-tested the instrument and concluded that the needs of elementary-and secondary-school teachers 
were different requiring differentiation in inservice education heretofore overlooked.

Differentiation of inservice training on the basis of needs assessments is logical from a variety of standpoints, including the fact that teacher training needs are not static. As teaching conditions change, concomitant changes are viewed in inservice training. (p. 2)

While the 1960s and 1970 s brought much information on the purposes of inservice education as well as information on the characteristics of successful inservice education and the best delivery modes for such, their great contribution was the highlighting of the importance of the teacher as a partner and determinant in successful inservice education.

\section{Statement of the Problem}

Inasmuch as there is an active and costly inservice program which exists for the $K-12$ teachers of the Lake Union Conference of Seventh-day Adventists, the question has been raised whether the teachers' perceived needs had been taken into consideration when planning inservice programs.

\section{Purpose of the Study}

The purpose of this study was to identify the perceived inservice needs of the $K-12$ teachers of the Lake Union Conference of Seventh-day Adventists currentiy employed within its educational system. In order to adequately address the problem as stated above the researcher studied several consequential auxiliary questions which include: 
1. Tracing what has been written and published on the major issues of inservice education including perceived inservice needs of teachers.

2. Analyzing the perceived inservice needs of the teachers of the Lake Union Conference of Seventh-day Adventists by years of experience and teaching assignment. Research questions (see page 80 and 811 . such as the following were posed:

a. What are the perceived inservice needs of all $\mathrm{K}-12$ Lake Union Conference teachers?

b. What are the perceived inservice needs of Lake Union Union Conference elementary teachers who teach grades K-8?

c. What are the perceived inservice needs of Lake Union Conference secondary teachers who teach grades 9-12?

3. Recommending specific ways for meeting the perceived needs of the teachers in this study.

\footnotetext{
Importance of the Study

Adequate inservice education has been recognized as an important part of the educational process of teachers (Moffitt, 1965). As such it is perceived to be at the heart of all education.

Proper education of the nation's teachers is and should be the concern of every citizen. It is the education of teachers that determines the quality of learning and therefore the quality of people of this country. . . It therefore appears safe to conclude that the quality of any school system may largely be determined by the quality of the inservice educational program involving the total professional staff. ( $p .7)$

Inservice education has traditionally aimed at addressing the problems of either getting undegreed or uncertified teachers degreed or certified or retraining teachers for an updated content
} 
and methodology. The 1980s, however, have brought new and unanticipated demands and purposes to inservice education. One can hardly depend only on the content of the past educational inservice programs. A cutback in the teacher corps because of decreasing enrollment has to a large extent eliminated undegreed and uncertified teachers. The question now is what the shape of inservice is to be for these remaining teachers and how should the content of inservice training for these teachers be determined in order to get the best returns on the dollar? If the answer to successful inservice education was previously seen to lie in teacher participation and in determining the perceived needs of the teachers involved, would not that same solution be of value again? The answers to these questions are seen to be of national interest, yet literature on experimental investigation of this is scarce.

How much has Seventh-day Adventist educational leaders made use of the teacher as a partner and determinant in inservice education? To this researcher's knowledge it appears no study has to date been conducted to determine the extent to which the educational leaders of the church have utilized the participative and needs assessment approach either nationally or in the geographical area of the Lake Union Conference of Seventh-day Adventists.

The extent to which current inservice programs meet the needs of their teachers is not known. If the answer to the above questions are of national importance to American education generally, it could also be of specific significance to the educational administration of the Lake Union Conference of Seventh-day Adventists. Furthermore, 
if Mauth (1962), Bugelski (1956), and Bigge (1964) are correct that inservice programs are more effective and greatly improved by greater teacher participation in their planning, then that factor ought to figure strongly in the development of any inservice programs that the Lake Union Conference of Seventh-day Adventists might develop in the future.

The findings of this dissertation appear to be the first published data on the perceived inservice needs of the teachers in the Lake Union Conference of Seventh-day Adventists. The data presented in this dissertation could give the educational leaders of the Lake Union Conference a knowledge base from which to plan future inservice education programs. The review of the related literature provides a concensus of the views of educators upon which to form a theoretical base for the development of successful inservice programs.

\section{Basic Assumptions}

It was assumed for the purpose of this study that:

1. Teachers have perceived needs for inservice which are not being met at the present time.

2. Teachers can adequateiy perceive and express their need for professional growth.

3. Inservice education based on the teacher's perceived need would provide a more highly desirable basis for successfui professional growth.

4. There is a difference in the perceived needs of teachers at different grade levels. 


\section{Del imitations of the Study}

This study was delimited to the teachers in the Lake Union Conference of Seventh-day Adventists which did not include nonteaching principals and supervisors.

\section{Limitations of the Study}

1. The study was limited to the concepts which relate to the regular educational program provided for by the Lake Union Conference of Seventh-day Adventists.

2. The study was limited to the extent to which teachers can articulate their needs.

\section{Definition of Terms}

For the purposes of this study, the following definitions are used:

Inservice Education is that portion of professional development which takes place during employment and which consists of systematically organized meetings conducted for a number of educators to increase their competencies, knowledge, skills, and attitudes needed by school personnel in the performance of their assigned responsibilities.

Teacher's Perceived Needs is the teachers' interpretation of an instructional activity or competency that is needed for them to perform more effectively in the classroom.

Combination elementary and secondary is when a teacher is involved on both the elementary and secondary level.

Multi-grade is a classroom where an elementary certified teacher teaches more than one elementary grade. 
Elementary is kindergarten through grade eight.

Secondary is ninth, tenth, eleventh, and twelfth grades.

Lake Union Conference is a geographical and administrative unit of the Seventh-day Adventist Church which is made up of five local conference encompassing the states of Michigan, Illinois, Wisconsin, and Indiana.

Conference is an adminsitrative unit of the Seventh-day Adventist Church which is made up of an area or one state, such as Michigan.

Supervisor is a person from each individual conference who assists the teachers in their teaching assignments.

Need is a gap in educational outcomes or results. It is the discrepancy between the current results (not procedures or processes) and the desired or required results (Kaufman \& English, 1975).

Needs Assessment is the formal process for identifying outcome gaps between current results and desired results placing those gaps in priority order and selecting the gaps of highest priority for closure. It is, then, an outcome gap analysis plus the placing of priorities among the needs (Kaufman \& English, 1975).

\section{Organization of the Study}

The organization of the study involves five chapters.

Chapter I includes the introduction, statement of the problem, purpose of the study, importance of the study, basic assumptions, delimitation, limitations, definition of terms, and organization of the study.

Chapter II gives a review of literature which contains an historical overview of inservice training development, purposes of 
inservice education, characteristics of successful and unsuccessful inservice programs, delivery systems, cooperative inservice education programs, varying needs of teachers, and planning strategies. Chapter III describes the research design, the methodology used for collection of data, the population, and the instrument tabulation used in the study. Chapter IV presents the data results and Chapter V summarizes the findings of the study, drawing conclusions and making recommendations. 
CHAPTER II

\section{REVIEW OF THE RELATED LITERATURE}

\section{Introduction}

This chapter reviews the relevant literature which surfaced as a result of this study relating to the inservice needs of teachers. The review of the related literature constitutes a theoretical framework for thinking about inservice education and for evaluating the effectiveness of inservice educational programs. As such, it forms both the background and basis for the evaluation of the findings of the perceived inservice needs of the teachers in the Lake Union Conference of Seventh-day Adventists as reported in chapter IV of this study.

The literature on inservice education is reviewed by first giving an historical overview of inservice education followed by a consensus discussion of the purposes of inservice education. Next is given an overview of what is considered by educators to be the characteristics of successful and unsuccessful inservice education, the inservice education perceptions of teachers, successful modes of delivery systems, and the preferred planning strategies.

\section{Historical Overview on Inservice Education}

Inservice education over the years passed through several modal stages, as revealed by the literature, but it also experienced a pluralization of purposes. 
Substitutions for College Education

Tyler (1971, p. 5) wrote that during the past 120 to 130

years the country was committed to the concept of universal elementary education. During the mid-1800s teachers did not have the benefit of a college education. Some had limited formal training in the art of teaching but were allowed to teach because most adults had little knowledge of reading or writing and even less knowledge of what should be taught in schools. Yearly institutes were held for new teachers to update their profession. The public accepted this as adequate preparation.

Degree Completion and Summer Schools

Tyler (1971, p. 8) continued that from 1889 until after World War I, the type of inservice education provided for teachers were summer courses offered by normal schools. After World War I until the Great Depression the main purpose of summer school was to enable teachers to complete their college degrees (p. 11). This meant that colleges and universities concentrated on filling the need for these courses.

\section{Certification}

The Great Depression, according to Tyler ( $p$. 12), forced a reexamination of the inservice education of teachers and school curriculum. A need to keep more students in school resulted in the universities and colleges introducing new courses and new methods of inservice education for teachers.

Tyler stated that after World War II the baby boom brought increased enroliments and with this a shortage of teachers. This 
changed the direction of inservice education in order to enable teachers to qualify for certification.

Sputnik Era--Science and

Mathematics Emphasis

During the 1960s inservice education focused on improving the science and mathematics curriculum (Tyler, 1971, p. 13). The primary impetus for this came from the space program and other technological advances. Inservice education concentrated on preparing teachers to cope with new trends.

The Seventies and Reexamination

of Inservice Training

During the 1970s inservice education turned to implementation and examination of the schools' goals and objectives (Tyler, 1971 , p. i5). Joint planning of inservice education by teachers and administrators was another step forward in some districts. It did not seem proper for administrators to dictate any longer the content of inservice education. Teachers were well educated and felt they could successfully contribute to joint planning sessions. This trend in turn brought an emphasis on determining the perceived need of teachers in order to plan effective inservice educational programs (Ingersol1, 1978, p. 1; Nigaiyaya \& Hanley, 1978, pp. 309-10). In fact the 1970s constituted a complete reevaluation of everything related to inservice education such as the nature, purpose, existing program modes, delivery systems, interest groups, and characteristics of successful inservice training programs.

For the highpoints of the results of the reexamination of inservice education one turns to the next sub-sections of this chapter. 
Purposes of Inservice Education

Naturally one of the first concerns of educational researchers

was to determine why inservice training programs should exist.

Updating, Continuation, and Com-

pletion of Formal Education

The purpose of inservice education, according to Hass (1957,

p. 211), Smith and others (1961, p. 173) was stated as follows:

. . The major purpose for inservice education is to promote

the continuous improvement of the total professional staff of

the school system. All teachers, administrators, and supervisors must study constantly in order to keep up with advances in subject matter and in theory and practice of teaching. Continuous inservice education is needed to keep the profession abreast of new knowledge and to release creative abilities.

Frandson (1980, p. 63) stated that a complete rethinking had taken place defining what is an adequate preparation for today's professions. It is no longer considered necessary to try to cram all of the professional preparation into undergraduate and graduate programs. These programs have become "the gate of entry into a lifetime of challenge in the broader realms of learning and accomplishments." Professionally trained teachers have an obligation to continue to enhance and to develop their abilities. Teachers should prepare the citizens of tomorrow and feel at home with technical advances. If teachers were not prepared to work in the world of expanding knowledge and advancing technology, they would be holding back students' development.

McManana (1972, p. 61) concurred with Broudy (1978, p. 59) that inservice education programs should help teachers keep up to date or latest developments in new content, teaching materials, tecinniques, and innovations that have taken place in the field of 
education. Researching, observations, visitation, meetings, college courses, and professional conferences could help toward this goal. The teacher would continue to have high morale and interest in teaching if administration allowed teachers to take advantage of these types of inservice programs.

Student Performance and Teaching Improvement

Bush (1971, p. 38) maintained the following was the purpose of inservice education:

The only true "index of the programs" quality lies in the teacher's classroom performance and ultimately in the students" learning. Surely the ultimate objective and purpose is to improve the student's learning but there are intermediate objectives at which inservice education can be aimed. The alternation of teacher behavior can be considered as a legitimate objective in and of itself. It is essential, in the final analysis to link teacher behavior to changes in pupil behavior, but there are intermediate stages in which it is not necessary to apply this full link.

The real purpose of inservice education was to improve the total learning environment for children and youth, advocated Zeran (1953, p. 257), and Smith and Others (1961, p. 173). The most important part of this learning environment was the teacher and their involvement.

The improved preservice education of school employees, wrote Yeager (1959, p. 77), does not always decrease the need for continued inservice education. It was expected that employees would grow professionally because of performed assigned tasks without an awareness of advances that may have taken place. The purpose of inservice education was to acquaint teachers with new methods, skills, and social changes that had occurred. 


\section{Problem-Solving Orientation}

According to Tyler (1978, p. 152) the individuals who had the responsibility for inservice education should be held accountable for helping teachers to become professional problem solvers guided by concepts and principles. Tyler pointed out four purposes of inservice:

1. Remediation

2. Developing the competence necessary to deal with specific problems

3. Assisting the teacher in learning what is necessary to attain professional goals

4. Giving stimulation and educational opportunities to counteract boredom and lowered professional performance.

Tyler's purposes could be accomplished if the people who have the responsibility for inservice education ensu:e that well-defined goals are attained. Tyler continued that enthusiasm, initiative, intelligence, and energy of the teachers can help to make the inservice education a meaningful program that will help to develop the individuality of the teachers rather than pressing them all into the same conformity (p. 153).

Stone (1969, p. 189) found inservice education activities attempted to cover four primary objectives. These were:

1. To change attitudes toward the problems encountered in teaching

2. To increase personal knowledge, understanding, and appreciation of pupils

3. To improve professional knowledge and skills and to 
increase effectiveness in providing instruction to meet the special needs of pupils

4. To modify personal and professional behaviors in the classroom and school (Stone, 1969, p. 190).

A variety of workshops, scholarly presentations, small group discussions and interactions, and practicums used to implement inservice programs to meet these objectives, according to Stone (1969, p. 191).

\section{Salary Improvement}

Houston and Freiberg $(1979$, p. 7) indicated that the major incentive for teachers to continue their education was to gain an increase in salary. This was true of typical inservice programs.

\section{Morale Building}

Harrison and Gowin (1958, p. 251) contended that because of the large number of teachers that became discouraged and left the profession, raising teachers' morale should be one of the goals of inservice, one reason for encouraging teachers to participate in any part of the inservice education.

\section{Socialization}

Mackie and Gervais (1979, p. 9) indicated that once inservice education had provided for teacher's basic needs, another function should take place, namely, the need for socialization. Every inservice program should provide adequate time for social interaction of participants. During these periods of socialization many ideas and experiences could be exchanged which could be valuable to teachers. One factor which would encourage a social discourse would be the 
seating arrangement. This would encourage questioning and practical answers could be shared. Inservice workshops would not only serve as a center for dissemination of knowledge but for exchanging ideas.

\section{Characteristics of Successful and Unsuccessful Inservice Programs}

Successful Programs

The effective inservice programs described by Berman and Friederwitzer (1980, p. 51) and those preferred by teachers possessed common elements for planning, implementation, and evaluation. Inservice should involve a continuous theme over a period of time, interspersed with classroom tryouts. According to Berman and Friederwitzer successful inservice should possess the following characteristics based on teachers' expressed needs.

1. Include teacher input early in the program, deal with curriculum change and innovation, providing teacher training prior to the onset of a new program.

2. Have immediate application to the classroom.

3. Combine subject-matter content with teaching methodology.

4. Include construction of teacher-made materials.

5. Employ activities for teachers that paralleled those to be used with children, thus creating a model for classroom application.

6. Provide teachers with a knowledge of subject matter before and after their particular grade level.

7. Include supervisory personnel as well as teachers in the same program.

8. Hold inservice education at the school building or building level.

9. Conduct inservice education during the school day with released time for participants.

10. Provide for ongoing, continuous evaluation of the process, the participants and the effects of the program on the student achievement. (Berman \& Friederwitzer, p. 51) 
Inservice for both teachers and administrators. Stoops, Rafferty, and Johnson (1981, p. 375) pointed out the necessity of inservice education for both teachers and administrators. This has resulted because of rapid changes in environment and technology.

It is the responsibility of each individual, stated Stoops, Rafferty, and Johnson ( $p .376$ ), to seek self-improvement and the responsibility of the school to provide opportunities for this to take place. Inservice should be based on the need assessment of school individuals.

Nine basic facts of inservice education according to. Stoops, Rafferty, and Johnson were:

1. Inservice programs have emerged from recognized needs of school and community.

2. School personnel need inservice education.

3. Proper supervision is an effective means of accelerating the inservice professional growth of personnel.

4. The quality of instruction is the immediate and long range goal of inservice education.

5. Inservice education leads to a continuous process of reexamination and revision of the educational program.

6. A concern of state agencies, colleges and universities, school boards, school administrators, and teachers has been inservice education.

7. Supervisors should create an atmosphere that stimulates a desire on the part of teachers for inservice.growth.

8. Inservice education should provide for keeping teachers abreast of important research and advances in education. 
9. Inservice education is most effective when cooperatively initiated and planned (p. 375).

Needs assessment of community, curriculum, and staff. Stoops, Rafferty, and Johnson (1981, p. 377) further maintained that inservice education must be flexible and adapt to the changing needs of community, curriculum, and staff. The principal was the key person in observing, consulting with, and advising and.helping teachers select inservice programs that would make them proficient.

Guidelines for improved inservice efforts were reported by 01 iva (1976, p. 395) and Hutson (1980, p. 6). They maintained that it was important to involve inservice clients in planning their own programs. This meant that data on teacher's. interests, needs, concerns, and problems should be assessed and made the important part of planning inservice activities.

According to Dull (1981, p. 112), inservice education programs were influenced by many factors, and to be effective they should include the following:

1. Relate to the district's goals

2. Evolve from a diagnosis of district, building, and individual's needs followed by programs to meet these individual needs in reference to district goais

3. Provide for continuous inservice education for all levels

4. Relate to goal setting by individual staff members with evaluation done in terms of these goals

5. Concentrate on changes in both subject matter and methodology

6. Utilize multiplication principles of recognizing staff 
members who are competent in specific skills so that they can train others

7. Relate theory and application in such a way that changes in staff behavior can be measured

8. Provide continuation of preservice training as the beginning of a continued development which is the responsibility of the local district and universities

9. Provide activities which are well planned and carried out for the mutual benefits of staff members and students

10. Initiate effective change within the school or school district (Dul1, 1981, p. 112).

Dull concluded (p. 113) that inservice education should leave an impact on teachers. Theoretically, this would make learning more exciting and significant for students. Teachers should have developed new teaching strategies and have new up-to-date knowledge to use in their teaching as a result of their inservice education.

Incentives and location. Hutson also stated that incentives for participation in inservice programs should emphasize intrinsic professional rewards. There should be limited dis-incentives, inconvenient times or locations or other factors that would penalize participation. Research literature did not support the concept that extrinsic rewards such as extra pay induced teachers to work harder planning or participating in inservice programs if professional motivation was absent. He also advocated that "the school site" was where inservice activities should be conducted.

of course, the exact nature of planned activities should be the determinant of location, but for the most purposes the school site has the distinct advantage of being "job-embedded." 
Inservice education should follow the developmental, not a deficit model. Teachers are not seen as needing inservice education because they lack the necessary skills to do an effective job. The developmental assumption is that teachers need not be weak in order to become stronger. (Hutson, p. 6)

Participative planning. Hutson and Silvernail (1980, p. 9) believed the best planners of inservice were people who participate in inservice programs. Equally important, the best planners were school personnel working together to assess and meet their professional needs. Hutson and Silvernail stated that the best providers of inservice were master teachers and administrators within local systems or those recognized by their fellow colleagues as having credibility and expertise within the inservice topic area. Outside consultants were acceptable as good providers if they were knowlegeable in the topic areas and were available for follow-up activities. The authors maintained that the time for inservice activities was during regular school hours and participation in inservice programs was necessary for professional development and self-fulfillment. The ultimate results of an inservice program were improvements in the instructional program for students. An additional benefit for the participants was better cooperation and communication among staff and administrators as well as improved morale, concluded Hutson (p. 6$)$. Houston and Freiberg $(1979$, p. 8$)$ contended that poorly planned inservice programs could be remedied by a conceptual model wherein teachers could participate. As educators, professional teachers should assume some responsibility for continued growth ( $p .10)$. This meant teachers should have a voice in the inservice programs that attempted to keep abreast with new trends and innovations in the field of education. 
Drumond (1979, p. 39) believed that inservice education should be managed by people who worked in the buildings and should deal with the individual, group problems, and concerns found there. The motives of those involved in inservice education needed to be apparent. A five-step technical assistance process approach to inservice education was advocated by Trohaus and Jackson (1980, p. 386). They maintained that an effective and efficient inservice program required an overall framework to guide its implementation employing the following steps:

1. Examining objectives

2. Assessing the client's needs

3. Preparing an agent-client agreement

4. Coordinating and delivering assistance

5. Evaluating the technical assistance.

In the event that additional assistance was needed, the individual might ask for another assessment and the cycle would be repeated (Trohaus \& Jackson, 1980, p. 386).

The distinguishing characteristics of a good inservice program presented by Alexander (1960, p. 152) contained the following points:

1. Relationship of the inservice program to the experimental background of the people

2. Cooperation of school systems, state departments of education, and universities

3. Well-organized conferences and workshops

4. Experimentation and action research

5. Work experiences of various kinds 
6. Participation in various studies by teachers and administrators, principles, and supervisors.

Al exander (1960, p. 156) thought growth would result for both leader and staff members when all cooperated and had as their common goal the improvement of the classroom atmosphere. There would be value in active participation of studying the problems which were of mutual concern and a policy would evolve democratically.

Chamberlain, Kindred, and Mickelson (1969, p. 359) and Kent (1979, p. 247) reported that local school administrators should give careful attention to establishing inservice procedures that allow "an on-going and response" of classroom-teachers' needs. If teachers were going to implement change, time should be given to plan, revise curriculum, discuss problems, try out new techniques, and to rethink instructional practices. At the same time, Kent maintained, the school administrators should realize that time was money and should have a workable plan before allowing teachers to fritter away valuable time. Both teachers and administrators have the responsibility to plan inservice programs and follow-up in such a way that the community would realize that results were being utilized in the classroom.

There should be active participation by teachers and other staff members in inservice, stated Harris, Bessent, and McIntyre (1969, p. 16). Inservice should be planned with individual needs as the central theme. However, the following practices still vioiated this basic idea in many ways.

1. Inservice planned for teachers by administrators

2. Plans based on superficial surveys of teachers' interests or needs 
3. Individual differences generally ignored

4. Programs in process rarely evaluated carefully when completed.

Harris, Bessent, and McIntyre (p. 17) were not aware of any plan that would eliminate all of these problems, but they felt inservice education should be planned with active participation of those who were to be the benefactors. Inservice programs should be designed with enough freedom to accommodate each individual, such as having a variety of activities that would meet the need of individual teachers.

Bush (1971, p. 66) maintained education should use experienced teachers to help inexperienced or beginning teachers. From their experience, these teachers could aid in the process of encouraging and helping new teachers cope with classroom joys and difficulties. Bush felt the change that was needed was to have "fewer global and so-called inspirational meetings." Efforts should be concentrated in building a repertoire of technical skills which would give teachers a different alternative when confronted with educational problems. This could be accomplished by tailoring inservice education to meet needs of specific groups of teachers or individual teachers. Bush also recognized (p. 67) different teachers have different abilities and students learn more effectively from different teaching methods. To implement this Bush felt teachers and their style of teaching should be matched to learning styles of students which could require a refinement of inservice education. 01 ivero (1977, p. 195) believed something could be done to 
eliminate negative feelings toward inservice programs. His beliefs were:

1. Deal with attitudes of the educationists. Teachers were expected to individualize instruction, diagnose, establish learning profiles, create learning centers and other instructional aides but had never been taught procedures or techniques in setting up the classroom for these concepts.

2. Gather information by assessing personal and professional needs.

3. Improve human relations and school climate. Personnel in some schools had sought ways to make the schools more productive and enjoyable for staff and students and positive solutions resulted.

4. Strive for personal growth. This was possible when teachers added to their professional growth.

5. Arrange time for inservice education. Time certainly must be made available if staff development was to take place (01ivero, 1977, p. 195).

01 ivero concluded by stating that successful inservice should be based on developmental theories of learning and should involve teachers in activity-oriented experiences with peer interaction encouraged to enhance learning of reievant iniormation ip. is5;.

Changes in knowledge and practice were beginning to make inservice relevant, maintained Cole (1982, p. 370). In addition there should be collaboration among people involved in the educational process. Teachers, administrators, and community--and even students--should be heard. Attention should be given to the participants' needs. Cooperation among schools, state departments, universities, 
and professional organizations should be taking place. In conclusion he stressed, "Collaboration, always collaboration."

Knowles (1970, p. 173) found people would accept responsibility for their own learning if they were honestly given the opporturity and a facility that would provide a chance for them to implement their newly learned knowledge. Knowles (p. 173) also observed that individuals of ten learned from each other and this exceeded what they learned from an outside authority.

Ihe emotions of the participants were not considered when an inservice presenter tried to teach new skills and concepts.

Furey $(1978$, p. 198) felt that the vehicle used in inservice education which gave personal growth and increased self-awareness was not the most important. The important factor was that educators should work together in an atmosphere of mutual concern so that the effects of a comprehensive inservice could be channeled into behavior that had a direct, positive impact on the growth of students in the schools.

There should be more attention given to teachers' competencies, noted Corno and Clark (1978, p. 172), which was the core of the daily classroom life of the average teacher, namely; (1) teacher planning, (2) decision making of the classroom, (3) analysis of classroom transactions, and (4) other maintenance procedures. Each teacher should be given tools to effectively measure the competency of teaching. Teachers should be encouraged to investigate new ways of teaching and to try their own ideas. Inservice education should provide the techniques by which these experiments could be conducted. Corno and Clark (1978, p. 173) 
further stated that such a program would take advantage of the concept that inservice teachers know what their teachers' needs and what their interests were and would make use of that knowledge to create training suitable for similar groups of teachers.

Purposeful planning. Cruichshank, Lorish, and Thompson (1979, p. 28) pointed out that inservice education does not give clear directions for individuals planning inservice for professional educators. There was not a consensus of opinion as to what the concepts were that made up inservice education. There was even a limited consensus about the definition of the term "inservice education." From research on the subject, there had emerged the following information about inservice programs.

1. School-based and college-based inservice education were equally successful in improving teachers' knowledge, but schoolbased programs were slightly more successful in improving teaching skills.

2. Teacher attitudes were improved more often in schoolbased than college-based programs

3. Mini-courses emphasizing development and application of teaching skills had a high rate of success in both college and school setting.

4. No medium of instruction--e.g., lecture/discussion, reading material, observations system--was clearly superior to others.

5. School-based programs in which teachers participated as helpers and planners of inservice activities tended to be more frequently successful than programs planned and conducted without teachers' assistance. 
6. Programs in which teachers engaged in self-instruction by using prepared materials, objectives, and planned guidance were successful.

7. Programs with conceptual or informational objectives were more successful in meting those objectives while programs with teaching objectives were less successful.

8. Programs that attempted to change teacher behavior only were more successful over programs that attempted to change teacher behavior and, consequentiy, pupil behavior.

9. Inservice programs that had different or individual training experiences for different teachers were more successful over programs that had common activities for all subjects.

10. Inservice programs that required teachers to construct and generate ideas, materials, and behaviors were more successful over programs in which teachers accepted ideas and behaviors from instructional agents.

11. Programs that emphasized demonstrations, supervised trials, and allowed feedback were more successful over programs in which teachers were expected to make unsupervised applications at some future time.

12. Programs in which teachers shared ideas and provided material assistance to each other were more successful over programs in which teachers did not.

13. Teachers were likely to benefit from inservice programs that were part of a long-term systematic staff development plan than they were from "single shot" short-term programs.

14. Teachers were likely to benefit from programs in which 
they chose their own goals and activities than from programs in which goals and activities were prepared.

15. Teacher self-initiated and self-directed activities were seldom used in inservice educational programs; but were highly successful in accomplishing objectives (Cruicshank, Lorish, \& Thompson, 1979, p. 28).

Unsuccessful Inservice Programs

Uninteresting and poorly planned. Teachers surveyed by Harris, Bessent, and McIntyre (1969, p. 15) agreed there was a need for inservice education but that most programs did not meet the teachers' needs. Criticisms centered around the fact that programs were dull and useless because they were generally planned, poorly timed, or devoted to administrative housekeeping. The following were areas where mistakes frequently occurred:

1. Not relating inservice education programs to genuine needs of the staff

2. Not selecting appropriate activities for implementing program plans

3. Not implementing inservice program activities with sufficient staff and other resources to assure effectiveness (Harris, Bessent, \& McIntyre, 1969, p. 15).

Another weakness was the priority placed on the inservice programs. They were limited in resources, money, and directions, stated Houston and Frieburg (1979, p. 7).

The people who were training teachers were not always well prepared. It appeared that additional time was needed for the development 
of a iogical framework in which the inservice programs could exist.

Inadequate funding. The history of education revealed that there had been inadequate provision made for inservice education of teachers in the past. Rubin (1978, p. 4) stated there were two main reasons for this:

1. Inservice was treated so casually that programs were clumsy and inept

2. Very little was known about the mechanics of teacher improvement.

At times, there was little incentive to improve programs. Rubin (p. 8) concluded that the legacy of inservice education was characterized by randomness and fragmentation, by programs that deferred to expediency rather than need, and by methodologies that were largely outdated.

Corrigan (1978, p. 255) was critical of education because he felt there was not a significant effort to provide a continuing education program for teachers. He stated other professions spent a certain percentage of their income on inservice education for members. Few school districts even provided the funds for further graduate work that all teachers were expected to have. Teachers were required to do this on their own time in the evenings, weekends, or during the summer. Teachers' salaries did not permit expenditure of large sums on professional literature that would benefit them. During the 1970s information was provided about the delivery of inservice education to teachers. Now the problem lay with the fact there were not enough funds to make these newly acquired practices a reality (Corrigan, 1978, p. 255). 
Unstructured university courses. Tracey (1971, p. 33)

observed that public and private enterprises encouraged personnel to study at colleges and universities, but self-study did not always relate to the goals and objectives or even the successful day-to-day operations of the enterprise. Encouragement offered to the professionals took the form of increased salary, time off to study, tuition payments, and a promise of a better position. The benefits of this type of study could be questioned, but enterprises had confidence in the results. University coursework was often something that the enterprise wished the individual to accomplish without the individual really wanting to. Such requirements could diminish the value that the individual received from an advanced degree. University education paid greater dividends if the individual had a desire to undertake advanced study.

School systems tried to improve their staff, wrote Wiles and Lovell (1975, p. 169), but the results did not satisfy anyone. Courses were chosen because of convenient scheduling or they were easily accessible. These sessions or courses were mandatory and the presentations were made to people who were not especially interested in the contents.

Chamberlain, Kindred, and Michelson (1966, p. 125) maintained that teachers did not cease to take college classes once they had graduated because they were required to take classes to maintain certification. Teachers were required to take additional study to obtain salary increases. Therefore teachers often took professional education courses that had little to do with their teaching assignment or the betterment of classroom skills. Inservice education that 
merely consisted of taking an additional college course had been open to criticism. Courses were made up of meaningless content, were uninteresting and were unrelated to the real world of teaching. According to Chamberlain, Kindred, and Mickelson (p. 126), professional courses taught by colleges had relied on state departments of education to dictate course content and had not involved teachers in planning the courses. Teachers could tell colleges where their professional weaknesses lay, but they needed help in solving or improving professional competencies.

No intrinsic motivation of teachers. Inservice education could serve to increase intrinsic rewards of teaching, advocated Palmer (1978, p. 218), while increasing teaching effectiveness of participants. Teachers valued success, and if inservice was structured to increase success of teachers, inservice education would increase the satisfaction the teacher derived from teaching. Inservice education would do this if it were designed to fulfill unmet needs of teachers and also provided tools that would make them effective in teaching. To accomplish this, programs should be conducted in a nonthreatening atmosphere. Materials should be presented in segments that would be assimilated by teachers. After these presentations, ample opportunity should be provided for the concepts to be implemented. It could be assumed that if teachers' chances of success were increased they would be more receptive to inservice.

Palmer (1978, p. 219) continued that this did not mean extrinsic rewards could not be an incentive for inservice education. However, this had been the standard type of motivation that was used in most inservice education. After years of ignoring the intrinsic 
motivation by inservice educators, extrinsic motivation had lost its influence on teachers.

Hasty and casual inservice education. Sportsman (1981, p. 307) stated: "Traditionally, inservice has been a hastily prepared, ineptly presented, an educationally stultifying event." He felt teachers had left the profession to escape from boredom of routine and lack of professional growth. These were the very concerns that inservice education was supposed to address. Typically, a consultant came to the district, tried to explain new concepts or methods in one or two sessions, and left--hoping teachers had absorbed the techniques.

\section{Delivery Systems}

High and Low Experience Impact Programs

Differences in inservice education delivery systems indicated a wide diversity of programs used by schools. Harris and Bessent (1969) designed a way to analyze the different delivery systems through analyzing the activities based on the "experience impact" of the teacher.

Activities may be arrayed from those with low experience impact to those with high experience impact on the learner. By experience impact we mean that the learner is more likely to interact with the learning situation in such a way that the experience will have some impact that will affect his later behavior. ( $p .34)$

The authors related the experience impact to three characteristics of the learning situation.

The first of these is the extent to which he can control the content of the experience. If he has some influence on the content of what is being presented, there is a greater chance that it can be made relevant to this past experience--an 
important principle in learning. The second characteristic is whether or not the learing experience is multisensory. Use of multisensory stimuli increases the probability that the learner will become involved in the learning situation.

Finally, whether communication is one-way or two-way will influence the accuracy of perception and affect confidence in what has been communicated. ( $p .34)$

The following diagram suggests several basic types of activities whichwere delivery systems and illustrates the order in which they were placed according to their "experience impact" (Harris \& Bessent, 1969, p. 35).

TABLE 1

EXPERIENCE IMPACT OF ACTIVITIES

\begin{tabular}{|c|c|c|c|c|}
\hline Activities & $\begin{array}{c}\text { Control of } \\
\text { Content }\end{array}$ & $\begin{array}{l}\text { Multi- } \\
\text { Sensory }\end{array}$ & $\begin{array}{c}\text { Two-Way } \\
\text { Communication }\end{array}$ & \\
\hline \multicolumn{5}{|l|}{ Lecture } \\
\hline Illustrated lecture & & $x$ & & $\begin{array}{l}\text { Low } \\
\text { Experience }\end{array}$ \\
\hline Demonstration & & $x$ & & Impact \\
\hline Observation & & $x$ & & $\uparrow$ \\
\hline Interviewing & $x$ & & $x$ & \\
\hline Brainstorming & $x$ & & $x$ & \\
\hline Group discussions & $x$ & & $x$ & \\
\hline Buzz sessions & $x$ & & $x$ & $\begin{array}{c}\text { High } \\
\text { Experience }\end{array}$ \\
\hline Role-playing & $x$ & $x$ & $x$ & Impact \\
\hline Guided practice & $x$ & $x$ & $x$ & \\
\hline
\end{tabular}

Inservice activities reflected "low experience activities impact" (p. 36). However, teacher involvement encouraged models which were based on "high experience impact" for 
teachers. The models of inservice education being advocated by teachers indicated Bloom's educational theory could aid in bringing about the following situations:

1. Increasing the number of inservice activity options to meet the individual needs of teachers

2. Providing opportunities for teachers to teach teachers

3. Allowing freedom to experiment and for self-evaluation (p. 36).

"Hands-on" Programs

Harris and Bessent (1969, p. 35) continued by describing the laboratory approach which utilized the "hands on" activities. One model which was based on this approach was the teacher center concept. A teacher center was a physical space where teachers developed programs for the training and improvement of education. It could be located within the district or school. At the teacher center participants were actively involved in problem solving which was as realistically portrayed as possible. Quantifiable data were then produced and recorded so participants had immediate feedback, allowing comparison with other members. Data were then discussed and analyzed so as to lead to ideas and solutions.

\section{Orummond's Inservice Models}

Drummond (1979, p. 39) classified inservice models into the following groups:

1. Provision-of-Service Model: People outside the faculty have services or ideas that would help the faculty. They would provide this service at a reasonable price. 
2. Job-Maintenance Model: Individuals in charge have mandated or strongly suggested teachers submit to remediation, update knowledge and skills, or take a required course or courses.

3. Personal-Development Model: The teacher feels that a new lease on life was needed to break out of the routine, to feel more in charge, and to restore one's energy and faith in people.

4. Problem-Solving Model: Teachers are dissatisfied with ridssroom happenings. Things could be better. They desire to have an inservice that attacks a specific weakness that all or just one seems to have (Drummond, 1979, p. 39).

Institutes and Workshops

Zeran (1953, p. 257), Stone (1969, p. 191), and Stoops, Rafferty, and Johnson (1981, p. 378) believed that within a school system there were a number of methods that could be used to make inservice meaningful. These included institutes and workshops, university work, travel, teacher's meetings, teacher visitation, professional publications, lectures and forums, and teacher centers.

\section{Successful Inservice Models}

A survey reported by Betz, Jensen, and Zigarmi (1978, pp. 491-93) assessed 1,239 South Dakota teachers' attitudes toward inservice education. The assessment indicated the following as most useful but least used.

1. Current trends in education workshop

2. In-classroom assistance from another teacher

3. Workshops on a college or university campus

4. Observations of teachers in other school system 
5. Special college courses conducted at the local school by a college or university staff member.

Unsuccessful Inservice Models

Continuing, the assessment determined the inservice activities that were used most but were the least helpful:

1. Reading bulletins, newsletters, brochures, and periodicals

2. Presentations by educational sales representatives

3. One hour to a ful1-day program conducted by outside consultants or other experts

4. Workshops held during the school year for intensive study of a local school problem (Betz, Jensen, \& Zigarmi, 1978, pp. 491-93).

Sharing Sessions

It was discovered through Ngaiyaye and Hanley's research (1978, p. 309) that teachers learned more from meetings organized for teachers of similar grades, subject fields, or programs. Another discovery, namely, the sharing of ideas among teachers, was often more important and informative for changing classroom instruction than great lectures. They also found it was beneficial when practice was emphasized rather than theory. Length of time for inservice education should be determined by subject matter and type of meeting. From the research ( $p .310$ ), Ngaiyaye and Hanley made the following recommendations.

1. Teachers should be actively involved pianning topics that pertain to their interests. 
2. Teachers do make a difference in what happens in the classroom.

Administrators must provide inservice programs to stimulate, challenge, and enhance teachers' professional growth (Ngaiyaye \& Hanley, p. 310).

\section{Performance Analys is Programs}

Fischier (1971, p. 185) found that teachers felt threatened by the principal sitting in the back of the room taking notes about the lesson being taught or the written lesson plans. For a change, Fischier suggested an observational record could be made by technology which would be less threatening. Afterwards, principal and teacher could focus on analysis of performance and center their discussion on alternative utilization of skills, goals, methods, and interpersonal relationships. Such a discussion could provide an opportunity for "a give and take" that would explore the availability of the alternate methods of teaching, therefore putting the principal in a helping role.

Seldin (1979, p. 266) believed school personnel wanted their inservice ( 1 ) to be conducted in their district, preferably during or immediately after school, rather than during vacations, evenings, or weekends; (2) involve concentrated one-day or one-afternoon meetings; (3) to incorporate small group sessions taught by outside consultants and/or university professors.

Wiles and Lovell (1975, p. 161) thought that an important influence over teachers in a school would be their peers. People in the central office would have less influence on teachers. 
Because of this it would appear money should be spent for the following inservice activities:

1. Opportunities for staff members to visit, observe, and participate in outstanding educational programs

2. Seminars built around the study of research on a given topic

3. Experiments that are an outgrowth of seminars

4. Seminars which consider evidence obtained from experiments

5. Demonstrations of practices that have been perfected

6. Clinics held as adjuncts to demonstrations

7. Classes to develop skills and concepts

8. Large group presentations.

Theory and Application Inservice Programs

For inservice education to be effective, theory, demonstration, practice, feedback, and classroom application must be included, observed Joyce and Showers (1981, p. 166). Through their studies, Joyce and Showers discovered that teachers were good listeners and could acquire new skills that improved their teaching competence. In order to learn these skills teachers needed some conditions that were not available in inservice sessions. Inservice education sessions should be planned to include the following:

1. Presentation of theory or description of skill or strategy

2. Modeling or demonstration or models of teaching

3. Practice in simulated and classroom settings 
4. Structured and open-ended feedback (provision of information about performance)

5. Coaching for application (hands-on, in classroom assistance with transfer of skills and strategies to the classroom) (p. 168).

Hencley, McCleary, and McGrath (p. 239) felt that certain minimal considerations were necessary for any inservice program to succeed. These were:

1. A primary goal should be the improvement of the teachers' competencies.

2. The atmosphere of sessions should be conducive to inquiry and research. Teachers' evaluations and other programs should be a meaningful part of inservice. If research data were used properly, new directions, changes, and methodology could take on meaning.

3. Group and individual teacher projects should be encouraged and planned.

\section{After Hours Inservice Programs}

Providing time to carry on inservice activities was an extremely important function maintained Sergiovanni and Elliott (1975, p. 254). Some teachers used time after school and even evenings and weekends to prepare for instruction and to work on selfimprovement. Over a period of time this could not be expected of teachers and provision for these activities should be scheduled as a part of the regular school year (p. 152). Time should be allotted for activities by using the following methods:

1. Dismiss school early or begin late to give staff members time to work together, with parents, or other adults. 
2. Provide special teachers, student teachers, parents, and volunteers to take over classrooms or groups of students in order to free teachers for periods of an hour or more.

3. Budget money that might be allocated for the salaries of central office supervisors and other nonclassroom personnal into salaries for additional classroom teachers and could rotate thus freeing a regular teacher (Sergiovanni \& Elliott, p. 152).

Specialist Advisors

It was Sergiovanni and Elliott's contention (p. 254) that a reallocation of funds should be used to provide specialists from different disciplines to heip teachers' effectiveness. This would permit teachers to become involved in kinds of work they do rather than following the practice of just accumulating more credits from college courses. Specialists would enhance teaching ability and enable teachers to deal effectively with classroom problems.

\section{Group Techniques}

Promising practices for inservice education should make use of protocol materials and brainstorming, wrote Neagley and Evans (1980, p. 276). These techniques should be evaluated to determine their effectiveness. The use of carefully planned group techniques could increase the chance of improving instruction. Neagley and Evans (p. 270) further stated that activities designed to enhance job performance of teachers, supervisors, and administrators could be labeled inservice education. However, if inservice education programs were to be received, they should be cooperatively planned and professionally executed. 


\section{Outside Agencies}

Another concept of Bush (p. 68) was that inservice education should be moved from administrative jurisdiction into "the hands of the teachers." Studies inferred that inservice education had been directed by administration and conducted for administrative purposes in many cases. Perhaps teachers could determine their needs and employ an outside agency which could present effective programs, designed to meet the teacher's needs. Bush (p. 67) suggested school systems should appropriate enough funds and resources for inservice education to insure quality results. Planning desirable conditions for inservice. and paying attention to the development of professional-quality materials were necessary to accomplish this task.

\section{In-School Programs and} Management Teams

Lippitt and Fox (1971, p. 161) developed a list of activities that should foster development and meaning to local inservice programs. These included:

1. School building meetings focused on professional problems

2. Principal-teacher consultation

3. Teacher consultation with university-based persons

4. School system supporting a particular action-research project

5. Utilization of a curriculum materials center for retrieval of basic research, innovations, and tools

6. Sessions for sharing practices

7. Clinic sessions with teachers from other systems

8. Internship with other projects on a released-time basis 
(curriculum projects, university-based development, or research activities)

9. Sensitivity training laboratory

10. College classes

11. Membership on an inside-outside team responsible for developing strategies for school or school system

12. Summer work sessions

13. Preschool workshops

Lippit and Fox (p. 166) concluded that the aforementioned could be accomplished by a management team consisting of teachers, supervisors, and administrators. A coordinator would help to facilitate team pians, thus improving the lines of communication between the various school groups.

\section{Extension Courses}

The extension course was a common form of inservice education, according to Hill and Potthoff (1959, p. 205). The opinion of college teachers was that quality of teaching in extension courses did not compare to courses taught on campus. In spite of this, extension classes were a growing and a valuable source of inservice education for the public. They provided a means of education that were available to people because classes could be located at different centers. Teachers that could not travel to a college or university could readily avail themselves of opportunities that extension courses provided.

Schaller (1975, p. 38) found graduate and continuing education through inservice education served to reinforce and update 
teachers. The role of inservice education was to compensate for deficiencies developed through current undergraduate programs. If a teacher were to remain effective, updating professional abilities was important. Being professional, according to Schaller, included the following:

1. Membership and participation in professional organizations

2. Extensive reading in professional journals

3. Provisions for interaction with fellow teachers

4. Involvement in the curriculum-planning process

5. Periodic attendance as relevant lectures, seminars, and workshops as well as work toward advanced degrees

6. Utilization of resource personnel and materials from public and private agencies ( $p .39)$.

The cooperative delivery systems are discussed in the next section of this chapter.

\section{Cooperative Inservice Education Programs}

Besides being handled state-wise, inservice education programs had also been cooperatively planned and administered with specific organizations. A review of the literature revealed the following models.

\section{School-based Programs}

Burnett (1979, p. 1) discussed a document written for administrators interested in establishing school-based competency inservice education. An alliance between a school system and a teacher training institution was outlined. It was recommended that common competencies 
be developed so teacher skills could be acquired. The project's main theme was the area of field-training, or on-the-job training, for teachers. The guide book covered the following topics:

1. Involving school administrators and teachers in learning activities

2. Improving attitudes in school systems

3. Conducting a needs assessment

4. Establishing competencies

5. Providing staff and financial resources

6. Suggesting time lines for activities, personal, and incurred costs.

Universities

Steps taken by a university to develop a meaningful inservice education were described by James (1979, p. 1). Faculty members were assigned by educational support teams to help schools identify needs, acquire resources, and work with individuals in intermediate school districts. The major emphasis was the active participation of teachers who would benefit from inservice courses designed.

\section{Teacher Education Centers}

Besides universities becoming involved in successful inservice programs, teachers' organizations had become involved putting forth their efforts for effective inservice education through Teacher Education Centers. Maloy and others (1980, p. 10) examined two separate programs in neighboring communities which approached developing teacher centers in two different ways. Both provided inservice education for staff and community. One program responded to teachers' 
needs by providing inservice education, staff development, community education, and materials for the high-school district it served. The other program originated as a comprehensive study of secondary education. It was based on concepts that people involved in a school system are also people best suited for establishing goals, identifying needs, and planning "the-on-going direction" of a school. Information was given on needs assessment, inservice programming, conducting research, and teacher centers.

Rationale, background information, fundamental theory and implementation strategy for a staff development model were outlined by Lhota (1976, p. 17). These focused on a teaching center which was designed to include part-time and full-time instructors. Lhota (p. 37) discussed the necessity of professional development for all faculty and using teacher-center facilities in providing inservice education.

Luke and others (1980, p. 10) gave steps for planning and developing inservice programs based on teacher centers. The emphasis was on ways to meet teacher inservice education needs in a teachercenter setting.

\section{Intermediate School Districts}

Intermediate school districts have become active in assuming leadership roles in inservice education, according to Edwards (1975, p. 70). The reason for this was the delegation of authority by state departments of education. Resources for manpower to administer the inservice education seemed to be available within intermediate school districts. Funding was also available within these districts. 
Several districts were involved in assessing their district with survey-type assessments.

\section{Planning Strategies}

\section{Planning Model}

Dull (1981, p. 130) pointed out ten factors vital to effective planning of inservice education. They were as follows:

1. Planning should begin with objectives of staff development.

2. Teachers should determine who would take part in inservice programs.

3. Time of the year and day of the week that programs are to take place should be established.

4. Types of inservice that would serve the needs of the group and resources of the district should be established.

5. Specific needs of the group should be determined.

6. Planners should organize a variety of activities.

7. Audiovisual materials should be prepared that enhance presentations.

8. Planners should give thought to location and facilities that wouid be needed

9. Inservice programs should be evaluated and summarized.

10. Appropriate incentives should be considered and used (Du11, 1981, p. 130).

Zeran (1953, p. 257) maintained group or cooperative planning was an important part that would help involve teachers and build competency. 


\section{Staff Participation}

Wiles and Lovell (p. 163) concluded that when courses and workshops held in a school system were structured to implement ideas the staff already accepted, meaningful courses and workshops resulted. People taking part in these activities would have to make application for these activities because participation indicated a willingness to accept and to put into practice those ideas gained from the presentations. Others who were slow to accept new ideas would then be influenced by leaders they accept and would make an effort to follow those individuals.

Focused District-wide Planning

It was postulated by Hencley, McCleary, and McGrath (1970, p. 238) that inservice education development of teachers and programs was a function of the personnel department, which could consist of district-wide activities as well as activities that occur within a given school or attendance area. However, a common goal must exist that would be enhanced by established priorities, welldeveloped schedules, meaningful participation, and a desire on the part of teachers to take part.

Bush (p. 68) thought educational estabiishments should not expect miracles from inservice education. "There should be improvements, but at times this may occur over a period of years and not be readily observable."

\section{Adequate Time Provision}

If teachers were expected to gain proficiency they should be given time and adequate inservice presentations which would allow 
them to absorb and implement new materials and knowledge ( $p .309$ ). To aid this process, Sportsman (1981, p. 310) suggested the following plan of action.

1. School districts should ally themselves closely to local universities.

2. Needs assessment should be conducted by representatives of the university, administration, and teachers in order to obtain balanced resources and to eliminate appearance of enforced results.

3. Inservice committees should be established to attack and resolve problems which needs assessment determined.

4. University classes on the new material should prove stimulating. Eventually these should be conducted by the local staff.

5. Development of a permanent information and retrieval system should be centrally located for teacher's use.

6. Classes should be started after the inservice program for the advanced degrees.

According to Sportsman (p. 311), the first three steps provided for foundation of the inservice; while the last thee areas dealt with positive significance of inservice education. The vital part of this program was the involvement at the three levels of participation.

Meaningful Technological Orientation

Inservice was unchanged over past years according to Howard, Test, and Cooke (1981, p. 16). The purpose of inservice education failed because newly discovered technologies were forced on teachers 
who lacked of understanding. Howard et al, gave the following steps to make inservice meaningful and new technologies more understandable:

1. Demonstrating hardware

2. Presenting instructional techniques

3. Producing software for teachers to use

4. Providing opportunities to teach in the visual response sys tem

Howard et al. (pp. 20-24) al so gave steps for planning, implementing, and evaluating inservice education. These were:

1. View the inservice as training, not as education

2. Use a systems approach to develop training programs

3. Employ a competency-based training model

4. Use technology in training

5. Practice new skills immediately following introduction

6. Require teachers to demonstrate and master use of technology with "real students"

7. Individualize the inservice program

8. Reduce as much as possible teachers' response cost for participation

9. Provide recognition and reinforcement for participating teachers

10. Conduct follow-up observations of teacher performance 11. Use continuous impact-based education 
Intensive Non-threatening Programs

It was the opinion of Goldhammer, Anderson, and Krajewski (1981, p. 8) that educational training and inservice education of the 1980 s would have to be more elaborate and intense than those of the 1960s and 1970s. The role of supervision would have to be expanded in helping teachers discover and remediate professional weaknesses. The programs should not be used to create an atmosphere of fear. If supervision would be properly used, rapport could be built between teacher and supervisor, resulting in a positive relationship. If properly used, supervision could help to detect weaknesses and would be a framework for improvement.

Differentiated Programs

Allen (1971, p. 112) realized that if inservice education was to be meaningful to educational professionals, a new boldness should be exhibited in educationai communities that would foster and capitalize upon multiplicity of educational tasks teachers performed. There must be a workable instructional form, the kind of distinctions among teachers' roles that makes educational sense. This could be accomplished by recognition of differentiated teaching staff. Different roles that were performed by teachers needed to be analyzed and criteria formulated which would allow for adequate judging of teachers' performances.

\section{The Varying Needs of Teachers}

Innovation and Teachers' Attitudes

Inservice education was a process which brought about change Postman and Weingarten (1969) maintained 
There can be no significant innovation in education that does not have at its center the attitudes of teachers, and it is an illusion to think otherwise. The beliefs, feelings, and assumptions of teachers are the air of a learning environment; they determine the quality of life within it. ( $p .30$ )

Rubin (1971) placed importance on "how the teacher felt about something, how strongly and in what order of importance." He felt these were tightly interwoven with his view of the educa-

tional process. He went on to say

the difference between routine teaching and inspired teaching depends to a large degree upon the teacher's own sense of motivation and commitment. The desire to change, if it is to be consequential, must come from within the individual teacher himself.

The way a teacher perceives of himself and his role, his attitude toward education, his belief in the children he teaches, and his basic commitments all influence the quality of his work. . . . Real learning causes the learner to alter his behavior. Inservice education, must offer a rich opportunity to acquire personal insights that lead to new ways of behaving in the classroom. (p. 251)

Combs, Avila, and Purkey (1971) looked at perceptions

and wrote the following:

All behavior of a person is the direct result of his field of perceptions at the moment of his behaving. More specifically, his behavior at any instant is the result of (1) how he sees himself, (2) how he sees the situation in which he is involved, and (3) the interrelations of these two. . . . To change another person's behavior it is necessary somehow to modify his beliefs or perceptions. When he sees things differently, he will behave differently. (p. 18)

Inservice Needs Differences between Individual Teachers

There appeared to be a difference in inservice needs of inexperienced teachers, observed Burlingman (1978, p. 158). The needs were as follows: 
1. More formal training in the area of college of education for local schools

2. Emphasis on the basic skills of teaching

3. Efforts to provide different sources of information for starting or inexperienced teachers

4. Development of prestige systems to enhance the status of inexperienced teachers.

\section{Teachers' Awareness of The ir} Inservice Needs

Inservice education critics concurred that inservice education could have immediate and long range effects on the improvements of professional training and classroom instruction, but there was still a question as to the format and content of the scheduled activities. Arena (1974, p. 43) discovered that the teachers knew as much if not more than the inservice speaker. This he found was evident by the "extremely intricate doodles that filled their notes, finishing overdue correspondence or expert demonstration of the eyes-openshallow-slumber techniques." However, reported Cruichshank, Kennedy, and Myers (1974, p. 154), the teachers still reported a desire for inservice education "if changes and improvements are made that make the procedures more responsive to their needs."

\section{Needs Assessment of Teachers}

Ingersoll's Teacher Needs Assessment Survey was developed at Indiana University by Gary Ingersoll. The purpose for developing the instrument was to provide a format which was reliabie and had a convenient form through which a variety of school systems 
could gather data on inservice needs using that data to plan inservice activities. The forty-three item instrument was developed and later revised in 1976 . The two primary resources used to generate the assessment were: (1) categories of teaching skills from existing catalogs of teacher ccmpetencies and (2) previous responses from prior attempts to categorize teachers' needs. Using these sources a series of forty-three items were chosen for use in the assessment. Five judges were asked to sort the items into seven clusters that shared a common concept. They were as follows:

1. Interpersonal Cormunication and Adninistration

2. Developing Pupil Self

3. Individualizing Instruction

4. Assessment

5. Discipline

6. Developing Personal Self

7. Classroom Management

8. Non-Factor Related Items

Using the Likert-type Scale, teachers were asked to indicate on a scale from one to five to what degree inservice education in a specific area or skill would be beneficial. Demographic data were also collected to indicate years of teaching experience, grade level of teaching, sex of teacher, and subject matter speciality.

The concepts of needs assessment to more effective inservice education was becoming a more useful and popular tool for decision making at all levels of education. Patterson and Czajkowski (1976) outlined the steps they felt were important for conducting such an assesiment. Included are the goals, the tools, performance indicators, data, and evaluation. 
Kaufman and English (1975) also outlined the steps involved in a needs assessment. These steps involved a simple model: "what is" and "what should be." The "need" was referred to as a "gap" which was first identified by Tyler (1975, p. 16) in his curriculum work at the University of Chicago.

Anderson (1980, p. 20) presented needs-assessment strategies for effective workshops. He outlined the advantages for this process in addition to formulating questions and applying this concept. A holistic approach to a needs assessment was advocated by Kaufman and Stakenas (1981). They felt that the basic "gaps" were those found in society's values, standards, and morals. They maintained that educators needed to think of these internal and external gaps when doing a needs assessment. They found that the holistic approach which goes beyond school boundaries provided a needed link between curriculum, instruction, and improvement.

Kaufman, Stakman, Wagner, and Moyer (1981, p. 19) differentiated among several different types of needs assessments. It was their desire upon completion of a paper that one would be able to describe the process of external and internal needs assessment relating to organizational efforts and results. They employed the various models and techniques to develop a program of intervention. based on perceived needs.

Needs assessment had been seen by Kuh, Hutson, Orbough, and Byers (1980, p. 16) as a "continuum of problem identification, negotiations, and resolutions." They pointed out that creativity, hardwork, and common sense had been under-emphasized, and these 
qualities were crucial in generating needed information for decision makers.

Other Needs-Assessment Models

Kimpston and Stockton (1981, p. 17) presented five needsassessment models which were representative of those employed by school districts throughout the United States. Each involved community and students as well as educational professionals. While needs assessment models existed, they did not prioritize or point educational planners to problems "where to begin (priorities) or where to end (goals)." They assisted readers in outlining approaches and techniques for setting priorities.

\section{Related Studies}

Borgealt (1969) investigated the problem of whether teachers with different professional backgrounds and experiences agreed on the degree of effectiveness of inservice education activities for improving their professional competency.

Data were gathered by means of a questionnaire designed for teachers which were sent to teachers in randomly selected buildings in randomly selected school districts of Iowa.

The following conclusions were made on the findings of the study:

1. In terms of effectiveness, the inservice activities were ranked in the following descending order: interclassroom vișitations, conferences and clinics, individual inservice conferences with specialists, directed professional reading, county and state workshops, local workshops, and faculty meetings. 
2. Beginning inexperienced and beginning experienced teachers agreed on the degree of effectiveness of all seven inservice activities.

3. Teachers within the elementary or secondary grade level from large, medium, and small school districts agreed on the degree of effectiveness of each of the seven activities except directed professional reading.

4. Elementary and secondary teachers agreed on the degree of effectiveness of only two activities: interclassroom visits and demonstrations and individual inservice conference with specialists. Elementary teachers saw the remaining inservice activities as more effective than did secondary teachers.

5. Teachers with one to seven years of teaching experience saw more inservice activities as less effective than do teachers with eighteen or more years of teaching experience.

6. Except for the activities of the local workshop and directed professional reading, teacher involvement in the planning stages of an activity was preferred by teachers at all levels of teaching experience.

7. For most inservice activities, elementary and secondary teachers favored teacher-planned activities over administrative planned activities.

Bigelow (1969) designed a study to establish guidelines for organizing and implementing a program of inservice education for professional staff members. The study attempted to obtain criteria for effective techniques of evaluating and for concepts of new innovations for inservice education. 
A questionnaire was prepared and submitted to 152 public schools with a student population $\mathrm{k}-12$ of 2,000 to 10,000 pupils in six midwestern states. Inservice coordinators were requested to (1) identify the technique currently utilized in their school district, (2) assert their opinion regarding the beneficial techniques, and (3) identify the three most effective inservice techniques and the three least effective techniques currently employed in their district.

Some of the findings were as follows:

1. Supervision of instruction and curriculum planning was being combined into one unit, the inservice program.

2. Many schools were implementing planned inservice programs executed on a year-around basis.

3. A need existed for more school time in which to plan and implement an inservice program.

4. There was a tendency for school systems to provide the teachers with an inservice curriculum.

5. The use of college consultants was becoming more prevalent in the public schools.

6. The building principal had a great responsibility in the inservice program.

7. There was a need for more systematic and objective evaluations of inservice education programs.

8. Professional growth for teachers was entering a new era and teacher involvement was becoming an important part of the professional growth program.

9. Money budgeted for inservice programs was far below that recomended in the literature. 
10. A written philosophy was a very important aspect of the inservice education program.

Pitts (1975) attempted to identify the perceived inservice needs of selected experienced elementary teachers and beginning elementary teachers in a selected urban school district. She sought to answer the following questions with a questionnaire:

Is there a relationship between teacher characteristics as perceived by teachers for inservice education?

Is there a relationship between student characteristics as perceived by their teachers and teacher-perceived needs for inservice education?

The following were Pitts' conclusions:

1. The school system should administer the inservice instrument to elementary teachers to ascertain their needs for inservice education.

2. Consideration should be given to providing inservice education to specific groups of teachers in the school system.

3. Further research should be conducted with beginning classroom teachers and experienced classroom teachers.

4. Additional research was needed to determine more effective ways of administering differentiated inservice programs.

5. A study should be conducted to identify the perceived needs of graduating seniors (enrolled in teacher preparatory training).

6. A study should be conducted to ascertain the needs of teachers who have not attended colleges, seminars, workshops, and other professional training in the last five years. 
Post (1975) investigated the perceptions of teachers and supervisory staff concerning inservice education as it was related to the skill needs of the individual teacher. An effort was made to determine the needs of teachers at various grade levels of the school system and to compare the teachers' stated needs with those that the supervisory staff at the same level perceived teachers as needing.

The conclusions of this study showed the following: (1) The majority of teachers and supervisory staff were not satisfied with present efforts at providing inservice. (2) The perceptions of the supervisory staff concerning teachers' skill needs and teachers' perceptions concerning their own skill needs were not always in agreement.

Bronson (1981) sought to determine if teachers and administrators in Seventh-day Adventist school systems differed in their perceptions regarding the appropriateness of inservice education programs.

The findings of Bronson's study indicated: (1) of the 120 comparisons that could be made between administrators and teachers as to the value of selected inservice programs, sixteen showed significant differences with administrators rating the inservice programs significantly higher than teachers. (2) In eighty-seven other comparisons, the administrators' ratings were equal to or higher than the teachers but not at significant levels. (3) Other significant differences were between male and female, various secondary teaching areas, and between elementary and secondary teachers. 
Summary

The review of the literature on inservice education discussed under the seven headings: Historical Overview, Purposes, Characteristics of Successful and Unsuccessful Programs, Delivery Systems, Cooperative Programs, Planning Strategies, and the Varying Needs of Teachers, revealed the following:

Historical Overview

Over the last 120 to 130 years inservice education has seen a shift from being an administratively planned program of remediation to a teacher-administrator program based on the assessed needs of the teachers involved. A fundamental questioning of all the aspects of inservice education was carried out during the 1970s and 1980s.

\section{Purposes of Education}

Inservice education was basically aimed at the improvement of pupil achievement to be achieved via the creative motivation of a skillful teacher whose knowledge of the course content and of student learning were updated in a contineous program of inservice education. As such the purposes of inservice training were varied by the completion of formal education, updating of knowledge and skills in the onward search of the knowledge explosion. Other purposes listed were salary improvement, certification, teacher morale, socialization, and problem solving.

Characteristics of Successful and Unsuccessful Inservice Programs

Successful programs were marked by teacher partnership in planning, were for both teachers and administrators, were purpose- 
ful, and were based on the assessed needs of a community, the curriculum, and the teacher. They were of a "high experience impact" kind and had immediate application to the classroom, combining subject matter with methodology and often including teacher-made materials. It was found in most cases that programs held at school giving released time worked well. Continuous and on-going programs worked best, particularly when scheduled at convenient times. The unsuccessful programs were such because of dullness, poor timing, poor funding, lack of structure, unrelatedness to the needs of the teacher (no intrinsic motivation), and inept presentation having little if any teacher involvement in the planning, implementation, and evaluation.

\section{Delivery Systems}

The suggested delivery modes ranged from workshops, institutues, seminars, university courses, extension courses, correspondence courses, lectures, forums, travel, conferences, teachers' meetings, teacher visitations, outside agencies, professional publications, clinics, and teacher centers. The desired length of time for any of these programs depended on the subject matter. The best time for these programs was after school with released time rather than weekends or over vacations. The kind of programs that modeled or provided skill development in a classroom setting worked best.

\section{Cooperative Inservice Programs}

Cooperative programs arose where schools, school districts, universities, or teacher centers provide both the revenue and the planning for the program. 
Planning Strategies

Planning strategies included teacher participation involved, where possible, other interested parties. Specific goals were kept in mind ensuring adequate, yet intensive, time provision for audiovisual aids, a variety of activities, a suitable location, adequate fundings, and provision for the varied needs of all the participants. The planning should be long range in scope.

\section{Varying Needs of Teachers}

The literature revealed that the needs of teachers varied depending on their actual teaching assignment and number of years of service. Findings indicated teachers should be canvassed for the ir opinions on teacher inservice needs. Several researchers had developed instruments for measuring these needs. Among these the recently developed Ingersoll Teacher Needs Assessment Survey proved promising. Studies to date indicated researchers had found quite different perceived needs between administrators and teachers. Differences were even found between teachers at various grade levels.

The review of the literature appeared to strongly support the concept of the teacher as a participative planner and determinant of the inservice education program at all levels. 
CHAPTER III

RESEARCH DESIGN AND METHODOLOGY

OF THE STUDY

This chapter contains information on the sample, the instruments used to gather data for this study, and the method employed in the analys is of the data.

\section{The Sample}

The present study was delimited to currently employed K-12 teachers in the geographical area in the United States known as the Lake Union Conference of Seventh-day Adventists. The Lake Union Conference in turn consists of the four geographical areas in the United States known as the states of Illinois, Indiana, Michigan, and Wisconsin. (See figure 1, p. 69.) For denominational administrative purposes, four conferences named after the states, and one conference known as the Lake Regional Conference of Seventh-day Adventists administered by a black church constituency and covering all four of the states make up the Lake Union Conference of Seventh-day Adventists.

The sample 289 of both black and white teachers studied consisted of 153 elementary school teachers, 63 secondary school teachers, 56 teachers who teach both elementary and secondary, and 17 principal/teachers. The latter were included because some 


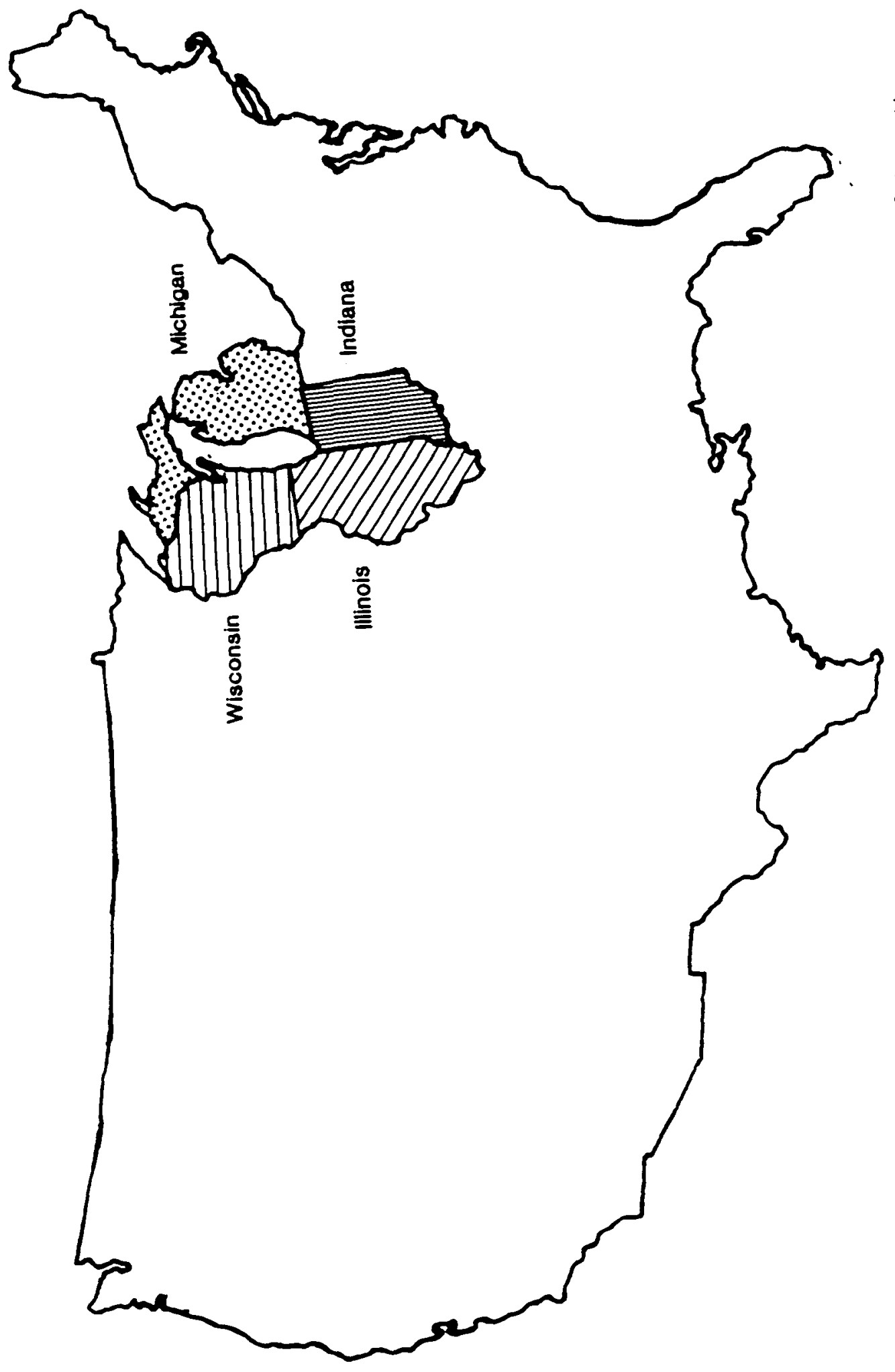

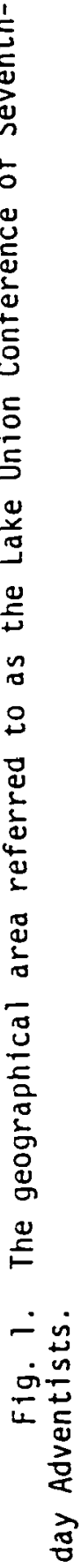


principals have the additional task of teaching. The distribution of teachers from the five administrative areas of the church were as follows: (see fig. 2, p. 71).

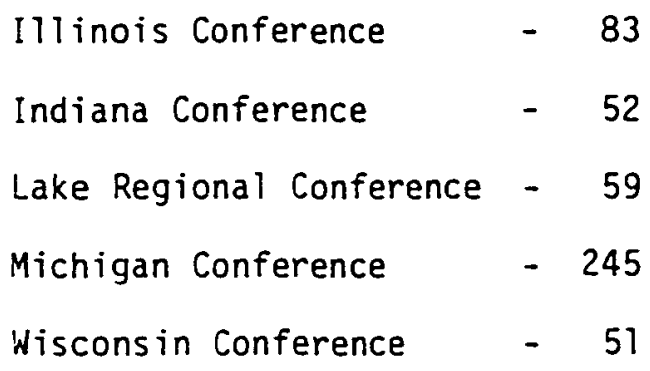

Since the sample of teachers studied comprised the total teacher population of the Lake Union Conference of Seventh-day Adventists, the teachers came from small schools and large schools located throughout the four states in rural, suburban, and metropolitan areas.

\section{Description of the Instrument}

The instrument used in this study was the Lake Union Conference Inservice Assessment (see appendix A). The instrument was initially authored by Gary Ingersoll of Indiana University, Bloomington, Indiana, and is known as Teacher Needs Assessment Survey. The researcher modified one section of the research instrument with the permission of the author in order to accommodate the religious aspect of the curriculum which is a natural component of the curriculum in Seventh-day Adventist schools.

The Lake Union Conference Inservice Assessment (LUCIA)

The LUCIA instrument spread over four pages consists of three sections. The first section on the front page gathers demographic 


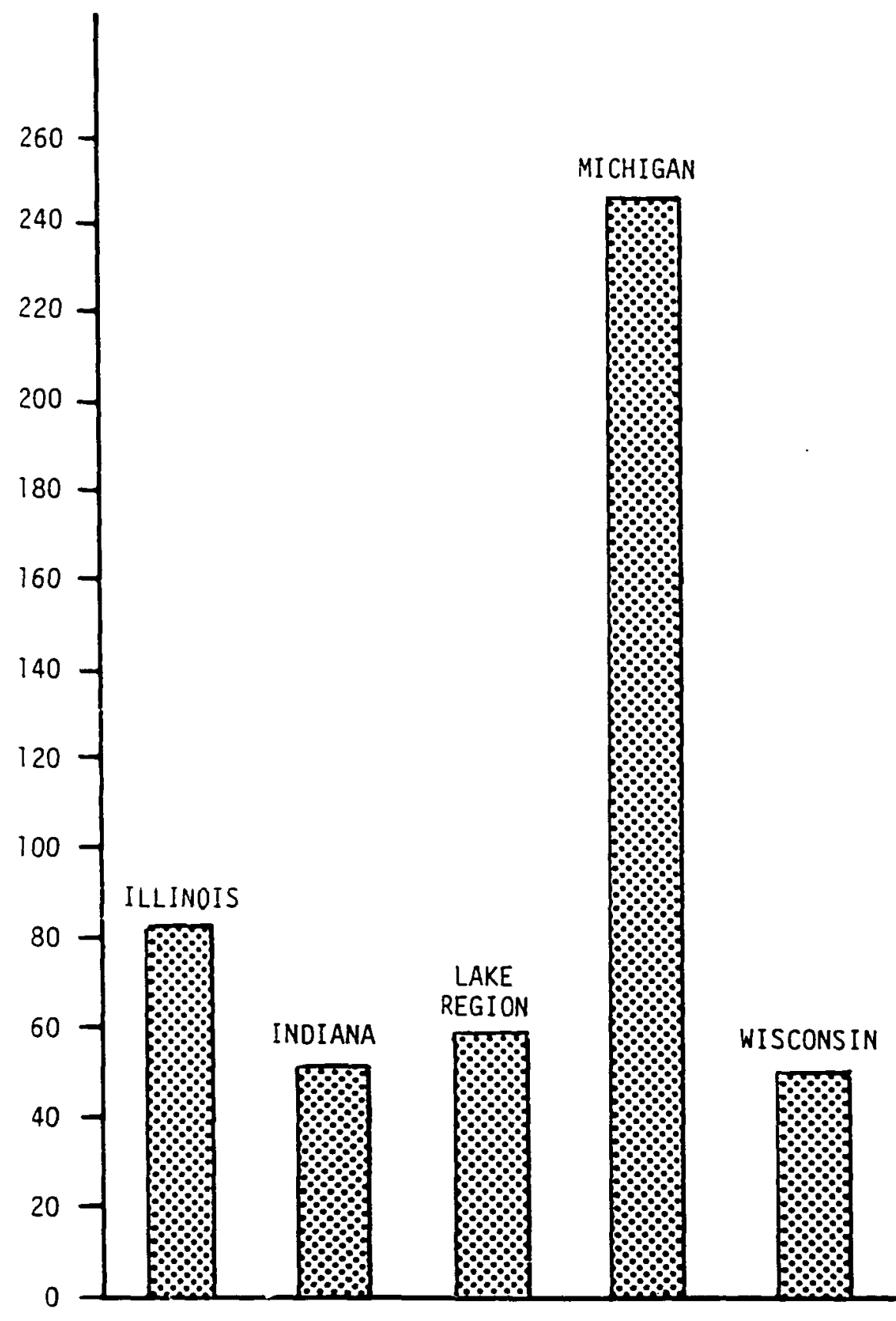

Fig. 2. Teachers employed by individual conferences of the Lake Union Conference for the school year 1982-83. 
information from the respondent. The second section (pp. 2,3) contained the actual needs-assessment survey. The third section on the back page provides space for the respondents' suggestions on additional inservice ideas.

A closer examination of the various sections of the survey instrument is as follows:

Section I, Demographic Data, was further subdivided into the following four parts:

1. "Years of Teaching Experience" asked the respondents to mark the appropriate years of experience on a grid.

2. "Teaching Assignment in the Elementary School (grade or combination of more than one)" presented the respondents with nine different grade levels from which to choose and mark accordingly.

3. "Teaching Assignment in the Secondary School (content area)" presented the respondent with twenty different subject or content areas and asked him/her to indicate the subject area(s) by marking the appropriate code.

4. "Conference" where teacher was employed presented the five different conferences of the Lake Union Conference of Seventhday Adventists and required each respondent to indicate the appropriate conference by marking the grid.

Section II contained forty-six questions grouped unevenly into nine categories. These questions constituted the actual needs-assessment survey. Each category contained from two to twelve questions. Each of the item statements was followed by the response categories of "strongly disagree," "disagree," 
"undecided," "agree," and "strongly disagree." The nine categories of questions were deemed by the instrument developer to cover the total spectrum of the educational experience. The nine categories of questions are:

1. Interpersonal Communication and Administration

2. Developing Pupil Self

3. Individualizing Instruction

4. Assessment (of students and teaching)

5. Discipline

6. Developing Personal Self

7. Classroom Management

8. Non-Factor Related Items

9. Integration of Faith, Learning, and Practice

The categories and the appropriate items are as follows:

I. Interpersonal Comunication and Administration

25. Knowing where to refer student problems beyond what can be handled by the teacher

28. Communicating and interacting with parents

29. Counselling and conferring with students

30. Involving others in the school program

II. Developing Pupil Self

35. Facilitating pupil self-concept and worth

36. Facilitating pupil social interaction

37. Facilitating development of pupil responsibility

38. Stimulating growth of pupil attitudes and values

39. Instilling in the students the will to learn on their own initiative 
13. Motivating students to learn on their own

III. Individualizing Instruction

9. Developing the use of computers in the classroom

11. Creating useful remedial material

15. Selecting and developing materials, activities appropriate for individualized instruction

16. Implementing and supervising individualized instruction

IV. Assessment

2. Constructing and using tests for evaluating academic progress

5. Establishing appropriate performance standards

6. Involving students in self-evaluation

12. Evaluating instruction/instructional design

33. Selecting and specifying performance goals and objectives

40. Developing or modifying instructional procedures to suit your own strengths

V. Discipline

26. Useful methods of classroom discipline and when to use it

27. Maintaining classroom control without appearing as an ogre to students

VI. Developing Personal Self

31. Developing a personal self-evaluation method

32. Developing a broad acceptance of self

34. Developing a capacity of accepting others' feelings 
VII. Classroom Management

7. Student-teacher verbal interaction

20. General presentation of information and direction

21. Deciding on appropriate pupil-grouping procedures for instruction

VIII. Non-factor Related Items

1. Diagnosing basic learning difficulties

3. Identifying student disabilities that need referral to special remedial work

4. Identifying student attitudes in order to better relate to problems

8. Deciding what teaching technique is best for a particular intended outcome

10. Planning teaching activities with other teachers or administrators

14. Keeping abreast of developments in your or. subject matter areas

?7. Using questioning procedures that promote discussion

18. Utilization of audiovisual equipment and other mechanical aids

19. Gearing instruction to problem solving

23. Constructively using evaluation in helping student progress

24. Managing classroom affairs in order to get maximum benefit from supervising, aids, tutors, etc.

41. Identifying the gifted and talented students 
IX. Integration of Faith, Learning and Practice

42. Developing better understanding of the theory of interpreting faith, learning, and practice and what makes it work

43. Knowing how to achieve faith, learning, and practice from the curriculum through written objectives and evaluating results

44. Constructing and implementing a Christian witness program for students and teachers together

45. Transforming faith into action by vicarious experience, developing Christian values and attitudes

46. Making Bible instruction more applicable to everyday life

The questionnaire which is self-administering requires only twenty to thirty minutes for completion and serves to indicate what areas of inservice education are perceived to be the respondent's specific needs.

Validation of the Lake Union Inservice Assessment (LUCIA)

After developing the initial Teacher Needs Assessment Survey, Ingersoll tried out the instrument on 745 teachers--364 elementary school teachers, 187 junior high-school teachers, and 188 highschool teachers. Of these 745 teachers, 204 had one to four years teaching experience, 195 teachers had five to nine years teaching experience, and 364 had ten or more years teaching experience. Ingersoll stated the following: 
Teachers were asked to respond to each item of the Assessment in two ways, indicating (1) how they saw each training area as a need of teachers in general, (2) how they saw each training area as a personal need. The purpose of this dual rating was to determine whether any major discrepancy existed between the two points of view. The teachers were asked to indicate on a Likerttype scale whether or not inservice training in a specific area or skill would be beneficial.

Estimates of internal consistency for the instrument were exceptionally high. The reliability estimate for ratings of training needs for "self" was .95 while the comparable estimate for perceived training needs of "others" was .97 for the needs assessment instrument. In spite of the high reliability coefficient for "others' needs," however certain statistical findings and conceptual problems led to a decision to remove that dimension of the questionnaire from further analysis. An inspection of the adjusted mean ratings for "selves" and "others" indicated that of the 43 identified training needs areas, ai $i$ ij were viewed as being needed more by "others" than by "self." Further, the correlation between the mean rating for "selves" and "others" over 43 skill areas was $r_{x y}=$ .96 suggesting that the differences in rating of "selves" and "others" reduce to a nearly perfect linear transformation. (Ingersoll, 1976, p. 169)

Teacher responses were submitted to factor analysis to identify clusters of perceived inservice needs. The resultant matrix of rotated factors yielded seven factors accounting for 95 percent of identifiable common variance, identification, and labeling of categories.

Subsequent to this the same instrument was successfully used by other researchers such as pitts (1975). For use in this study, the researcher constructed the items in Category IX with the aid of a classroom teacher, an elementary school principal, a university professor, and the researcher's committee chairman after reviewing the articles authored by Akers and Moon (1980), "Integration of Faith, Learning, and Practice," Journal of Adventist Education. This modification was done with the permission of the author of the instrument, Dr. Gary Ingersoll. Section III, Additional Inservice Ideas, asked the respondents 
to add any additional inservice ideas they may have which were not provided for in the forty-six. item statements contained in Section II.

\section{Data Gathering Procedures}

Initial permission from the superintendent of schools in the Lake Union Conference of Seventh-day Adventists opened the way for the researcher to explain the forthcoming survey and the purpose to the five conference superintendents of schools in the Lake Union Conference of Seventh-day Adventists. They gave their support.

In August 1982, the researcher sought and obtained the permission and cooperation of the administrators of the Lake Union Conference of Seventh-day Adventist via the Lake Union Conference Principals/Superintendents Council (appendix B).

Permission was then obtained to administer the survey to all of the secondary-school teachers of the Lake Union Conference of Seventh-day Adventists at a teachers' conference. Ouring one of the general sessions, time was allowed for introduction of the research and questionnaire. The questionnaire was distributed at that time and collected at the start of the next general session. The respondents were instructed to mark with a pencil the degree to which they agreed or disagreed to each inservice education need.

At the conclusion of the conference, each attending educational superintendent took the instrument to the elementary-school teachers of his conference for completion. An introductory letter accompanied each packet (appendix $C$ ). Due to the fact that one of the educational superintendents was not in attendance at the 
teachers' conference, the instrument was mailed to each teacher of that conference with a cover letter explaining the instrument and purpose of research (appendix 0 ). To insure proper return, a stamped self-addressed envelope accompanied each instrument. Three weeks later, a letter of reminder was sent to the educational superintendent of the conference asking for his additional support to have the survey instruments returned (appendix $E$ ). A letter of reminder was also sent to each teacher who had previously received an instrument for completion (appendix $F$ ).

By December 15, 1982 the researcher began to process and analyze the data that had come in via the Lake Union Conference Inservice Assessment.

\section{Data Analysis}

The response items were processed by the Xerox Sigma $V i$ used for educational research at the Andrews University Computer Center, Berrien Springs, Michigan. The responses for each item on the Likert-type scale were weighted giving strongly disagree - 1, disagree - 2, undecided - 3, agree - 4, and strongly agree - 5, which provided an indication of the degree to which respondents agreed or disagreed with the statement. This weight of 1 to 5 to the alternative answers gave the same numerical values to the responses that showed the greatest favorableness toward the concept. A computer summarization of each item gave to it a weighted score. The possible weighted score was derived by multiplying the number of respondents in that group times five. The responses to the items were divided into the following percentage groups: $89-90,79-70$, 
69-60, and 59-50. The percentage groups gave a clearer description of the different items and categories. The items were ranked using the weighted scores. The nine categories were ranked according to the mean score of each category, then using the weighted score, each item within the category was ranked. The ranking of the items in the category were described and tabulated in graphic form.

In analyzing the data the researcher sought answers to the following twenty-one research questions:

1. What are the perceived inservice needs of the $K-12$ Lake Union Conference teachers?

2. What are the perceived inservice needs of the Lake Union Conference elementary teachers who teach grades $\mathrm{K}-8$ ?

3. What are the perceived inservice needs of Lake Union Conference elementary teachers who teach grades $\mathrm{K}-2$ ?

4. What are the perceived inservice needs of Lake Union Conference elementary teachers who teach grades 3-5?

5. What are the perceived inservice needs of Lake Union Conference elementary teachers who teach grades 6-8?

6. What are the perceived inservice needs of Lake Union Conference secondary teachers who teach grades 9-12?

7. What are the perceived inservice needs of Lake Union Conference secondary teachers who teach the different disciplines (i.e., math, Bible, history)?

8. What are the perceived inservice needs of Lake Union Conference elementary teachers who have taught $0-5$ years?

9. What are the perceived inservice needs of Lake Union Conference elementary teachers who have taught 6-10 years? 
10. What are the perceived inservice needs of Lake Union Conference elementary teachers who have taught 11-15 years?

11. What are the perceived inservice needs of Lake Union Conference elementary teachers who have taught 16-20 years?

12. What are the perceived inservice needs of Lake Union Conference elementary teachers who have taught 21 + years?

13. What are the perceived inservice needs of Lake Union Conference secondary teachers who have taught $0-5$ years?

14. What are the perceived inservice needs of Lake Union Conference secondary teachers who have taught $6-10$ years?

15. What are the perceived inservice needs of Lake Union Conference secondary teachers who have taught $11-15$ years?

16. What are the perceived inservice needs of Lake Union Conference secondary teachers who have taught 16-20 years?

17. What are the perceived inservice needs of Lake Union Conference secondary teachers who have taught 21 + years?

18. What are the perceived inservice needs of Lake Union Conference el ementary teachers who teach three or fewer grades?

19. What are the perceived inservice needs of Lake Union Conference elementary teachers who teach more than three grades?

20. What are the perceived inservice needs of the Lake Union Conference teachers who teach elementary and secondary grades?

21. What are the perceived inservice needs of take Union Conference principals who also function as teachers?

Chapter IV contains the presentation and analysis of the data gathered by way of the Lake Union Conference Inservice Assessment. 
CHAPTER IV

PRESENTATION AND ANALYSIS OF THE DATA

The purpose of this study was to identify the perceived inservice educational needs of the $k-12$ teachers of the Lake Union Conference. In this chapter the data are presented according to the procedures outlined in chapter III. In the first section the findings are summarized with respect to the assessment instrument returns. The second section presents answers relative to the data collected for the twenty-one questions posed by the study in chapter III.

\section{The Findings}

Of the 490 teachers assessed in the Lake Union Conference of Seventh-day Adventists, a total of 289 teachers returned their completed assessment questionnaires. None of these questionnaires were discarded as spoiled or as incomplete. The net result reflects a 59 percent usable return of questionnaires. A calculation of the percentage returns from the various conferences in the Lake Union Conference of Seventh-day Adventists revealed the following:

Illinois Conference: $\quad 72.3$ percent (60 out of 83 teachers) Indiana Conference: $\quad 80.8$ percent (42 out of 52 teachers) Lake Region Conference: 23 percent (14 out of 59 teachers) Michigan Conference: 52.4 percent (133 out of 245 teachers) Wiscons in Conference: 78.4 percent (40 out of 51 teachers) 82 
Description of the Data

The following data are based upon the responses of the 289 K-12 Lake Union Conference teachers. The findings of the research are organized and presented in descriptive narrative, tables, and graphs. The returned raw data are displayed in appendix $G$ showing the total responses to each item, the ranking of the items, and the weighted score of the item.

\section{Item and Ranked Categories for All K-12 El ementary and Secondary Teachers}

Ranked Items--K-12 Teachers

The description of the items is presented in ranked order and put into percentage groups. By ranking the findings (table 2) it was found that of the 46 items on the assessment survey, there were 5 items which scored between the 89-80 percent level of the possible weighted score of 1445 (289 teachers $\times 5$ ). Item 46 , Making Bible Instruction More Applicable to Everyday Life, ranked the highest with a weighted score of 1215, which was 84 percent of the possible weighted score. The remaining 4 items in this percentage group had a range of weighted scores from 1183 to 1173 . Item 39, Instilling in the Student the Will to Learn on His Own, ranked second. Item 45, Transforming Faith into Action--By Vicarious Experience--Developing Christian Values and Attitudes, and item 13, Motivating Students to Learn on Their Own, had an equal number of totally agreed and strongly agreed responses (237). Of the 5 items in this group, 3 came from the category of Integration of Faith, Learning, and Practice, and 2 came from the category of Developing Pupil Self. 
TABLE 2

RANKED ITEMS FOR ALL. K-12 TEACHERS

\begin{tabular}{|c|c|c|c|c|c|c|c|c|}
\hline $\begin{array}{l}\text { Item } \\
\text { Number }\end{array}$ & Inservice Needs & $\begin{array}{r}\text { Rank } \\
\text { Order }\end{array}$ & $\begin{array}{l}\text { Weighted } \\
\text { Score }\end{array}$ & $\begin{array}{l}\text { Raw } \\
\text { SD-1 }\end{array}$ & $\begin{array}{l}\text { Scores } \\
\text { D-2 }\end{array}$ & $\begin{array}{l}\text { (Res } \\
U-3\end{array}$ & $\begin{array}{l}\text { Sponse } \\
\text { A-4 }\end{array}$ & $\begin{array}{l}\text { es) } \\
S A-5\end{array}$ \\
\hline 46 & Making Bible more applicable to everyday life & 1 & 1215 & 006 & 022 & 015 & 110 & 136 \\
\hline 39 & $\begin{array}{l}\text { Instilling in the student the will to learn } \\
\text { on his own initiative }\end{array}$ & 2 & 1183 & 008 & 022 & 020 & 124 & 115 \\
\hline 44 & $\begin{array}{l}\text { Constructing and implementing a Christian } \\
\text { witnessing program for students and } \\
\text { teachers together }\end{array}$ & 3 & 1179 & 006 & 019 & 030 & 125 & 109 \\
\hline 45 & $\begin{array}{l}\text { Transforming faith into action by vicarious } \\
\text { experience-developing Christian values } \\
\text { and attitudes }\end{array}$ & 4 & 1176 & 006 & 016 & 030 & 137 & 100 \\
\hline 13 & Motivating students to learn on their own & 5 & 1173 & 006 & 025 & 021 & 131 & 106 \\
\hline 38 & $\begin{array}{l}\text { Stimulating growth of pupil attitudes and } \\
\text { values }\end{array}$ & 6 & 1134 & 008 & 029 & 023 & 146 & 083 \\
\hline 42 & $\begin{array}{l}\text { Developing a better understanding of the theory } \\
\text { of IFLP and what makes it work }\end{array}$ & 7 & 1133 & 006 & 030 & 039 & 120 & 094 \\
\hline 09 & $\begin{array}{l}\text { Developing the use of the computer in the } \\
\text { classroom }\end{array}$ & 8 & 1128 & 011 & 023 & 058 & 088 & 109 \\
\hline 01 & Diagnosing basic learning difficulties & 9 & 1121 & 008 & 027 & 030 & 151 & 073 \\
\hline 14 & $\begin{array}{l}\text { Keeping abreast of developments in your own } \\
\text { subject area }\end{array}$ & 10 & 1105 & 006 & 044 & 033 & 118 & 088 \\
\hline 35 & Facilitating pupil self-concept and worth & 11 & 1098 & 009 & 039 & 022 & 150 & 069 \\
\hline 37 & Facilitating development of pupil responsibility & 12 & 1080 & 011 & 038 & 037 & 133 & 070 \\
\hline
\end{tabular}


TABLE 2--Cont inued

\begin{tabular}{|c|c|c|c|c|c|c|c|c|}
\hline $\begin{array}{l}\text { It tem } \\
\text { Number }\end{array}$ & Inservice Needs & $\begin{array}{l}\text { Rank } \\
\text { Order }\end{array}$ & $\begin{array}{l}\text { Weighted } \\
\text { Score }\end{array}$ & $\begin{array}{l}\text { Raw S } \\
\text { SD-1 }\end{array}$ & $\begin{array}{l}\text { cores } \\
D-2\end{array}$ & $\begin{array}{l}\text { (Res } \\
U-3\end{array}$ & $\begin{array}{l}\text { ponses } \\
A-4\end{array}$ & s) \\
\hline 03 & $\begin{array}{l}\text { Identifying student disabilities that need } \\
\text { referral or special remedial work }\end{array}$ & 13 & 1073 & 007 & 044 & 041 & 130 & 067 \\
\hline 15 & $\begin{array}{l}\text { Selecting and developing materials-activities } \\
\text { appropriate for individualized instruction }\end{array}$ & 14 & 1067 & 008 & 038 & 045 & 142 & 067 \\
\hline 43 & $\begin{array}{l}\text { Knowing how to achieve IFLP from the curriculum } \\
\text { through written objectives and evaluation }\end{array}$ & 15 & 1064 & 013 & 038 & 044 & 127 & 067 \\
\hline 26 & $\begin{array}{l}\text { Useful methods of classroom discipline and } \\
\text { when to use them }\end{array}$ & 16 & 1061 & 015 & 050 & 026 & 122 & 076 \\
\hline 11 & Creating useful remedial materials & 17 & 1056 & 009 & 048 & 042 & 125 & 056 \\
\hline 23 & $\begin{array}{l}\text { Constructively using evaluation in helping } \\
\text { student progress }\end{array}$ & 18 & 1049 & 006 & 039 & 054 & 147 & 043 \\
\hline 16 & $\begin{array}{l}\text { Implementing and supervising individualized } \\
\text { instruction }\end{array}$ & 19 & 1049 & 010 & 039 & 049 & 141 & 050 \\
\hline 19 & Gearing instruction to problell solving & 20 & 1040 & 006 & 045 & 045 & 156 & 037 \\
\hline 27 & Maintaining classroom control without. & 21 & 1019 & 017 & 061 & 031 & 106 & 074 \\
\hline 31 & Developing a personal self-evaluation method & 22 & 1019 & 009 & 051 & 056 & 125 & 048 \\
\hline 30 & Involving others in the school program & 23 & 1016 & 019 & 059 & 063 & 098 & 050 \\
\hline 29 & Counselling and conferring with students & 24 & 1016 & 013 & 063 & 029 & 130 & 054 \\
\hline 28 & Communicating and interacting with parents & 25 & 1016 & 016 & 063 & 029 & 118 & 063 \\
\hline 17 & $\begin{array}{l}\text { Using questioning procedures that promote } \\
\text { discussion }\end{array}$ & 26 & 1015 & 014 & 057 & 038 & 127 & 053 \\
\hline
\end{tabular}


TABLE 2--Continued

\begin{tabular}{|c|c|c|c|c|c|c|c|c|}
\hline $\begin{array}{l}\text { I tem } \\
\text { Number }\end{array}$ & Inservice Needs & $\begin{array}{l}\text { Rank } \\
\text { Order }\end{array}$ & $\begin{array}{l}\text { Weighted } \\
\text { Score }\end{array}$ & $\begin{array}{r}\text { Raw } \\
\text { SD-1 }\end{array}$ & $\begin{array}{l}\text { Score } \\
\text { D-2 }\end{array}$ & $\begin{array}{l}s(\operatorname{Re} \\
U-3\end{array}$ & $\begin{array}{l}\text { sponse } \\
\text { A-4 }\end{array}$ & $\begin{array}{l}\text { es) } \\
S A-5\end{array}$ \\
\hline 40 & $\begin{array}{l}\text { Developing or modifying instructional pro- } \\
\text { cedures to suit your own strengths }\end{array}$ & 27 & 1012 & 008 & 053 & 056 & 130 & 042 \\
\hline 04 & $\begin{array}{l}\text { Identifying student attitudes in order to } \\
\text { better relate to problems }\end{array}$ & 28 & 1010 & 012 & 055 & 046 & 130 & 046 \\
\hline 06 & Involving students in self-evaluation & 29 & 1004 & 012 & 049 & 051 & 144 & 033 \\
\hline 24 & $\begin{array}{l}\text { Managing classroom affairs in order to get } \\
\text { maximum benefit from supervising aides, } \\
\text { tutors, and etc. }\end{array}$ & 30 & 993 & 011 & 063 & 050 & 119 & 046 \\
\hline 10 & $\begin{array}{l}\text { Planning teaching activities with uther } \\
\text { teachers or administrators }\end{array}$ & 31 & 991 & 011 & 063 & 052 & 117 & 046 \\
\hline 25 & $\begin{array}{l}\text { Knowing where to refer student problems } \\
\text { beyond what can be handled by the teacher }\end{array}$ & 32 & 989 & 018 & 061 & 045 & 111 & 054 \\
\hline 36 & Facilitating pupil social interaction & 33 & 980 & 010 & 060 & 059 & 127 & 033 \\
\hline 12 & Evaluating instruction/instructional design & 34 & 978 & 006 & 055 & 077 & 124 & 027 \\
\hline 08 & $\begin{array}{l}\text { Deciding what teaching technique is best } \\
\text { for a particular intended outcome }\end{array}$ & 35 & 976 & 011 & 058 & 058 & 135 & 027 \\
\hline 32 & Developing a broad acceptance of self & 36 & 968 & 019 & 059 & 063 & 098 & 050 \\
\hline 02 & $\begin{array}{l}\text { Constructing and using tests for evaluating } \\
\text { academic progress }\end{array}$ & 37 & 956 & 015 & 074 & 039 & 129 & 032 \\
\hline 05 & Establishing appropriate performance standards & 38 & 954 & 010 & 067 & 065 & 120 & 027 \\
\hline 33 & $\begin{array}{l}\text { Selecting and specifying performance goals } \\
\text { and objectives }\end{array}$ & 39 & 949 & 016 & 061 & 065 & 119 & 028 \\
\hline
\end{tabular}


TABLE 2--Continued

\begin{tabular}{|c|c|c|c|c|c|c|c|c|}
\hline $\begin{array}{l}\text { Item } \\
\text { Number }\end{array}$ & Inservice Needs & $\begin{array}{l}\text { Rank } \\
\text { Order }\end{array}$ & $\begin{array}{l}\text { Weighted } \\
\text { Score }\end{array}$ & $\begin{array}{r}\text { Raw } \\
\text { SD-1 }\end{array}$ & $\begin{array}{l}\text { Scores } \\
D-2\end{array}$ & $\begin{array}{l}\operatorname{se} \\
U-3\end{array}$ & $\begin{array}{l}\text { sponse } \\
\text { A-4 }\end{array}$ & SA-5 \\
\hline 21 & Providing for reinforcenent & 40 & 948 & 014 & 069 & 061 & 112 & 033 \\
\hline 34 & $\begin{array}{l}\text { Developing a capacity of accepting others' } \\
\text { feelings }\end{array}$ & 41 & 941 & 019 & 073 & 050 & 109 & 038 \\
\hline 18 & $\begin{array}{l}\text { Utilization of audiovisual equipment and } \\
\text { other mechanical aids }\end{array}$ & 42 & 941 & 022 & 071 & 045 & 113 & 038 \\
\hline 41 & Identifying the gifted and talented student & 43 & 933 & 018 & 068 & 062 & 112 & 029 \\
\hline 07 & Teacher-pupil verbal interaction & 44 & 903 & 024 & 077 & 052 & 111 & 025 \\
\hline 22 & $\begin{array}{l}\text { Deciding on appropriate pupil grouping } \\
\text { procedures for instruction }\end{array}$ & 45 & 894 & 019 & 085 & 062 & 096 & 027 \\
\hline 20 & $\begin{array}{l}\text { General presentation of information and } \\
\text { directions }\end{array}$ & 46 & $79 \%$ & 034 & 106 & 059 & 076 & 014 \\
\hline
\end{tabular}


The next 22 items were between the 79-70 percent level of the possible weighted score of 1445, with weighted scores ranging from 1134 to 1012. Item 38, Stimulating Growth of Pupil's Attitudes and Values, ranked first. Item 42, Developing a Better Understanding of the Theory of IFLP and What Makes It Work, ranked second, and item 09, Developing the Use of Computers in the Classroom, ranked third in this percentage group. All three of the above items clustered together with only a 6-point range within the weighted scores. The range between the items was from 1 to 21 points. Item 30, Involving Others in School Programs; item 29, Counseling and Conferring with Parents; and item 28, Communicating and Interacting with Parents, each had the same weighted score of 1016. Two items, 27, Maintaining Classroom Control, and 31, Developing a Personal Self-Evaluation Method, had weighted scores of 1019. The 22 items in this percentage group came from all the categories except Classroom Management.

The third group which consisted of 18 items were in the 69-60 percent group and had weighted scores which ranged from 1010 to 894 . Items within this percentage group had a 2 to 30 point spread. Item 34, Developing a Capacity of Accepting Others' Feelings, and item 18, Utilizing A.V. Equipment, had the same weighted score of 941 . Within this group, item 22, deciding on Appropriate Pupil-Grouping Procedures for Instruction, had the largest number of disagreed with 85 responses, while item 12, Evaluating Instruction/Instructional Design, had the largest number of undecided responses (77). These perceived inservice needs came from six of the nine categories. 
The fourth group consisted of item 20, General Presentation of Information and Direction, which ranked 46 with a weighted score of 797 . This was below the 60 percent level of the possible weighted score of 1445. It had the largest number of disagree and strongly disagree with a total of 140 responses out of the possible total of $289 \mathrm{~K}-12$ teachers. This item came from the category of Classroom Management.

Of the 46 items on the assessment, 45 items were above the 60 percent level of the possible weighted score, 28 items were above 70 percent of the possible weighted score, and 5 items were above 80 percent of the possible weighted score of 1445 .

The top five perceived inservice needs of all the $k-12$ teachers of the Lake Union Conference were as follows:

1. Making Bible Instruction More Applicable to Everyday Life

2. Instilling in the Students the Desire to Learn on His Own Initiative

3. Construciing and Implementing a Christian Witnessing Program for Students and Teachers Together

4. Developing Christian Values and Attitudes through Vicarious Experience

5. Motivate Students to Learn on Their Own.

Three of the items, 1,3 , and 4 , were from Category IX, Integration of Faith, Learning, and Practice (see table 1). The other two items 2 and 5, were from Category II, Developing Pupil Self. 
Ranked Categories--All K-12 Teachers

The description of the categories is presented in ranked order (table 3). Likewise, the description of the items within the categories is also presented in ranked order, according to the responses (table 4 ).

Category IX, Integration of Faith, Learning, and Practice, ranked first among the nine categories. Item 46, Making Bible Instruction More Applicable to Everyday Life, ranked first in the category with 246 totalled agreed and strongly agreed responses. Item 44, Constructing and Implementing a Christian Witness Program for Students and Teachers Together, ranked second. Item 45, Transforming Faith into Action--by Vicarious Experience--Developing Christian Values and Attitudes, ranked third in the category with the highest number of agreed responses (137). Item 43, Knowing How to Achieve Faith, Learning, and Practice from the Curriculum through Written Objectives and Evaluating Results, ranked last with an 82 total of undecided and disagreed responses. Category IX consisted of 5 questionnaire items- $-42,43,44,45$, and 46 . The mean score of 1153 , shown in table 3 , was 80 percent of the possible weighted score of 1445 (289 teachers $\times 5$ ).

Category II, Developing Pupil Self, ranked second among the nine categories. Item 39 , Instilling in the Student the Will to Learn on His Own Initiative, ranked first in the category with a total of 239 agreed and strongly agreed responses. Item 13, Motivating Students to Learn On Their Own, ranked second. Item 35, Facilitating Pupil Self-Concept and Worth, ranked third in the category with the highest number agreed responses (150), whereas, 
TABLE 3

RANKED CATEGORIES FOR ALL $K$ - 12. LAKE UNION CONFERENCE TEACHERS

\begin{tabular}{|c|c|c|c|c|c|c|c|c|c|}
\hline Rank & Categories & 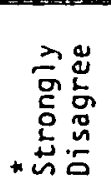 & 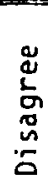 & $\begin{array}{l}. \\
0 \\
5 \\
5\end{array}$ & & 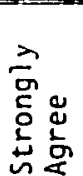 & 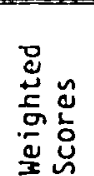 & 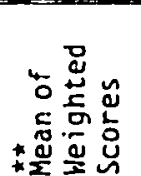 & 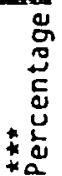 \\
\hline
\end{tabular}

1 IX Integration of Faith, Learning and Practice 115380 46 Making Bible instruction more applicable to everyday life

44 Constructing and implementing a Christian witness program for students and teachers together

45 Transforming faith into action--by vicarious experience--developing Christian values and attitudes

42 Developing a better understanding of the theory of integrating faith, learning and practice and what makes it work

43 knowing how to achieve faith, learning and practice from the curriculum through written objectives and evaluating results

$\begin{array}{llllll}006 & 022 & 015 & 110 & 136 & 1215\end{array}$

006

019030

25

91179

$\begin{array}{llllll}006 & 016 & 030 & 137 & 100 & 1176\end{array}$

$\begin{array}{llllll}006 & 030 & 039 & 120 & 094 & 1133\end{array}$

$\begin{array}{llllll}013 & 038 & 044 & 127 & 067 & 1064\end{array}$

II Developing Pupil Self

39 Instllling in the student the will to learn on his own initiative

13 Motivating students to learn on their own

38 Stimulating growth of pupil attitudes and values

35 Facilitating pupil self-concept and worth

37 Facilitating development of pupil responsibility

36 Facilitating pupil social interaction

$\begin{array}{llllll}008 & 022 & 020 & 124 & 115 & 1183 \\ 006 & 025 & 021 & 131 & 106 & 1173 \\ 008 & 029 & 023 & 146 & 083 & 1134 \\ 009 & 039 & 022 & 150 & 069 & 1098 \\ 011 & 038 & 037 & 133 & 070 & 1080 \\ 010 & 060 & 059 & 127 & 033 & 980\end{array}$


TABLE 3--Continued

\begin{tabular}{|c|c|c|c|c|c|c|c|c|}
\hline Rank & Categories & 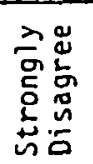 & 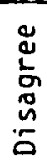 & 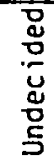 & 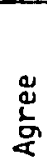 & 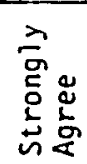 & 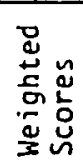 & 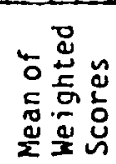 \\
\hline
\end{tabular}

3 III Individualized Instruction

09 Developing the use of the computer in the classroom

15 Selecting and developing materials activities appropriate for individualized instruction

11 Creating useful remedial materials

16 Implementing and supervising individualized instruction

1075

74

ipline

$\begin{array}{llllll}011 & 023 & 058 & 088 & 109 & 1128\end{array}$

$\begin{array}{llllll}008 & 038 & 045 & 142 & 056 & 1067 \\ 009 & 048 & 042 & 125 & 065 & 1056\end{array}$

$\begin{array}{llllll}010 & 039 & 049 & 141 & 050 & 1049\end{array}$

4

26 Useful methods of classroom discipline

27 Maintaining classroom control without appearing as an ogre to the students

$\begin{array}{llllll}015 & 050 & 026 & 122 & 076 & 1061\end{array}$

5 VIll Non-factor Related Items

01 Diagnosing basic learning difficulties

14 Keeping abreast of developments in your own subject matter area

03 Identifying student disabilities that need referral or special remedial work

23 Constructively using evaluation in helping student progress

19 Gearing instruction to problem solving

17 Using questioning procedures that

promote discussion

$\begin{array}{llllll}017 & 061 & 031 & 106 & 074 & 1026\end{array}$ 
TABLE 3--Continued

\begin{tabular}{|c|c|c|c|c|c|c|c|c|}
\hline Rank & Categories & 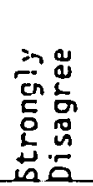 & 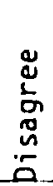 & 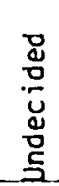 & 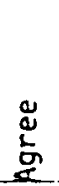 & 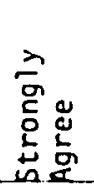 & 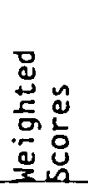 & 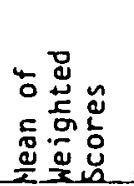 \\
\hline
\end{tabular}

04 Identifying student attitudes in order to better relate to problems

$\begin{array}{llllll}012 & 055 & 046 & 130 & 046 & 1010\end{array}$

24 Managing classroom affairs in order to get maximuin benefit from supervising, aids, tutors, etc.

10 Planning teaching activities with other teachers or adininistrators

08 Deciding what teaching technique is best for a particular intended outcome

18 Utilization of audio-visual equipment and other mechanical aids

41 Identifying the gifted and talented students

$\begin{array}{llllll}011 & 063 & 050 & 119 & 046 & 993 \\ 011 & 063 & 052 & 117 & 046 & 991 \\ 011 & 058 & 058 & 135 & 027 & 964 \\ & & & & & \\ 022 & 071 & 045 & 113 & 038 & 941 \\ 018 & 068 & 062 & 112 & 029 & 933\end{array}$

I Interpersonal Communication and Administration

28 Communicating and interdcting with parents

29 Counseling and conferring with students

30 involving others in the school program

25 knowing where to refer student problems

beyond what can be handled by the teacher

$\begin{array}{llllll}016 & 063 & 029 & 118 & 063 & 1016\end{array}$

$\begin{array}{llllll}013 & 063 & 029 & 130 & 054 & 1016\end{array}$

$\begin{array}{llllll}010 & 040 & 063 & 143 & 033 & 1016\end{array}$

sment

$\begin{array}{llllll}018 & 061 & 045 & 111 & 054 & 989\end{array}$

IV Assessment

40 Developing or modifying instructional procedures to suit your own strengths

06 Involving students in self-evaluation

12 Evaluating instruction/instructional design

$\begin{array}{llllll}008 & 053 & 056 & 130 & 042 & 1012\end{array}$

$\begin{array}{llllll}012 & 049 & 051 & 144 & 033 & 1004\end{array}$

$\begin{array}{llllll}006 & 055 & 077 & 124 & 027 & 978\end{array}$


TABLE 3-a Continued

\begin{tabular}{|c|c|c|c|c|c|c|c|c|c|c|c|}
\hline Rank & & & Categories & 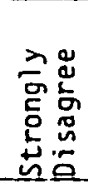 & 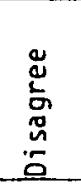 & 苔 & $\begin{array}{l}\text { د̃ } \\
\text { o. } \\
\text { ån }\end{array}$ & 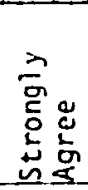 & 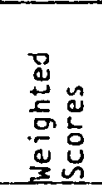 & 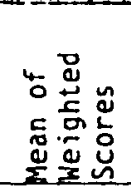 & 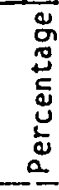 \\
\hline & & $\begin{array}{l}02 \\
05 \\
33\end{array}$ & $\begin{array}{l}\text { Constructing and using tests for } \\
\text { evaluating academic progress } \\
\text { Establishing appropriate performance standards } \\
\text { Selecting and specifying performance }\end{array}$ & $\begin{array}{l}015 \\
010\end{array}$ & $\begin{array}{l}074 \\
067\end{array}$ & $\begin{array}{l}039 \\
065\end{array}$ & $\begin{array}{l}129 \\
120\end{array}$ & $\begin{array}{l}032 \\
027\end{array}$ & $\begin{array}{l}956 \\
954\end{array}$ & \multirow{4}{*}{926} & \multirow[b]{3}{*}{68} \\
\hline & & & goals and objectives & 016 & 061 & 065 & 119 & 028 & 949 & & \\
\hline 8 & VI & $\begin{array}{l}\text { Dev } \\
31 \\
32 \\
34\end{array}$ & $\begin{array}{l}\text { eloping Personal Self } \\
\text { Developing a personal self-evaluation method } \\
\text { Developing a broad acceptance of self } \\
\text { Developing a capacity of accepting others. } \\
\text { feelings }\end{array}$ & $\begin{array}{l}009 \\
019 \\
019\end{array}$ & $\begin{array}{l}051 \\
059\end{array}$ & $\begin{array}{l}056 \\
063\end{array}$ & $\begin{array}{l}125 \\
098\end{array}$ & $\begin{array}{l}048 \\
050\end{array}$ & $\begin{array}{r}1019 \\
968\end{array}$ & & \\
\hline 9 & VII & $\begin{array}{l}\text { Cla } \\
21 \\
07 \\
22 \\
20\end{array}$ & $\begin{array}{l}\text { ssroom Management } \\
\text { Providing for reinforcement } \\
\text { Teacher-pupil verbal interaction } \\
\text { Deciding on appropriate pupil grouping } \\
\text { procedures for instruction } \\
\text { General presentation of information and directions }\end{array}$ & $\begin{array}{l}014 \\
024 \\
019 \\
034\end{array}$ & $\begin{array}{l}069 \\
077\end{array}$ & $\begin{array}{l}061 \\
052\end{array}$ & $\begin{array}{l}112 \\
111\end{array}$ & $\begin{array}{l}033 \\
025\end{array}$ & $\begin{array}{l}948 \\
903\end{array}$ & & 61 \\
\hline
\end{tabular}

* Raw Scores

* Mean of the weighted score for the category

$\star \star \star$ Percent of the possible weighted score 
TABLE 4

A SUMMARY OF THE RANKED CATEGORIES FOR ALL K-12 LAKE UNION CONFERENCE TEACHERS

\begin{tabular}{llcc}
\hline \multicolumn{1}{c}{ Categories } & $\begin{array}{c}\text { Mean of } \\
\text { Ranking } \\
\text { Order }\end{array}$ & $\begin{array}{c}\text { Percentage } \\
\text { of Possible } \\
\text { Weighted } \\
\text { Score* }\end{array}$ & $\begin{array}{c}\text { Score } \\
\text { Score }\end{array}$ \\
\hline IX Integration of Fafth, Learning, and Practice & 1 & 1153 & 80 \\
II Developing Pupil Self & 2 & 1108 & 77 \\
III Individualized Instruction & 3 & 1075 & 74 \\
V Discipline & 4 & 1044 & 72 \\
VIII Non-factor Related Items & 5 & 1021 & 71 \\
I Interpersonal Comimunication and Administration & 6 & 1009 & 70 \\
IV Assessment & 7 & 975 & 68 \\
VI Developing Personal Self & 8 & 926 & 68 \\
VII Classroom Managenient & 9 & 886 & 61 \\
\hline
\end{tabular}
in the group]. 
item 36, Facilitating Pupil Social Interaction, ranked last with the highest number of disagree and undecided responses. Category II consisted of 6 questionnaire items--13,35,36,37, and 39. The mean score of 1108, shown in table 3, was 77 percent of the possible weighted score of 1445 .

Category III, Individualized Instruction, ranked third among the nine categories. Item 9, Developing the Use of the Computer in the Classroom, ranked first in the category with 109 strongly agreed responses. Item 15, Selecting and Developing Materials Activities Appropriate for Individualized Instruction, ranked second with the highest number of agreed responses (142). Category III consisted of 4 questionnaire items--9, 11, 15 and 16 . The mean score of 1075, shown in table 3 , was 74 percent of the possible weighted score of 1445 .

Category $V$, Discipline, ranked fourth among the nine categories. Item 26, Useful Methods of Classroom Discipline and When to Use Them, ranked first with 198 totalled agreed and strongly agreed responses. Item 27, Maintaining Classroom Control Without Appearing as an Ogre to the Students, ranked last. Category $V$ consisted of 2 questionnaire items--26 and 27 . The mean score of 1044, shown in table 3, was 72 percent of the possible weighted score of 1445 .

Category VIII, Non-factor Related Item, ranked fifth among the nine categories. Item 1, Diagnosing Basic Learning Difficulties, ranked first in the category with 224 totaled agreed and strongly agreed responses. Item 14, Keeping Abreast of Developments in Your Own Subject Matter Area, ranked second with the highest number of 
strongly agreed responses (88). Item 41 , Identifying the Gifted and Talented Students, ranked last with the highest undecided responses (62). Category VIII consisted of 12 questionnaire items $-1,3,4,8,10,14,17,18,19,23,24$, and 41 . The mean score of 1021, shown in table 3 , was 71 percent of the possible weighted score of 1445 .

Category I, Interpersonal Communication and Administration, ranked sixth among the nine categories. Item 28 , Communicating and Interacting with Parents, ranked first with 63 strongly agreed responses. Item 29, Counselling and Conferring with Students, ranked second. Item 30, Involving Others in the School Program, ranked third. All three of the forementioned items--28, 29, and 30--had the same weighted score of 1016. Item 28 and item 29 each had 29 undecided responses. Likewise both items had 63 disagreed responses. Category I consisted of 4 questionnaire items--25, 28, 29, and 30 . The mean score of 1009 , shown in table 3 , was 70 percent of the possible weighted score of 1445 .

Category IV, Assessment, ranked seventh among the nine categories. Item 40, Developing or Modifying Instructional Procedures to Suit Your Own Strengths, ranked first with 42 strongly agreed responses. Item 6, Involving Students in Self-Evaluation, ranked second in the category with 144 agreed responses. Category IV consisted of 6 questionnaire items--2, 5, 6, 12, 33, and 40. The mean score of 975 , shown in table 3 , was 68 percent of the possible weighted score of 1445.

Category VI, Developing Personal Self, ranked eighth among the nine categories. Item 31, Developing a Personal Self- 
Evaluation Method, ranked first in the category with a total of 173 agreed and strongly agreed responses. Both item 32, Developing a Broad Acceptance of Self, and item 34, Developing a Capacity of Accepting Others' Feelings, had 19 strongly disagreed responses. Category VI consisted of 3 questionnaire items--31, 32, and 34 . The mean score of 926 , shown in table 3 , was 68 percent of the possible weighted score of 1445.

Category VII, Classroom Management, ranked last among the nine categories. Item 21, Providing for Reinforcement, ranked first in the category with 33 strongly agreed responses. Item 20, General Presentation of Information and Directions, ranked last with a total of 140 disagree and strongly disagree responses. Category VII consisted of 4 questionnaire items--7, 20, 21, and 22 . The mean score of 886 , shown in table 3 , was 61 percent of the possible weighted score of 1445 .

\section{Ranked Items--Elementary Teachers}

The description of the item is presented in ranked order and put into percentage groups. By ranking the items it was found there were 4 items which scored above 80 percent of the possible weighted score of 765 (153 teachers $\times 5$ ) (table 5). Item 46, Making Bible Instruction More Applicable to Everyday Life, ranked the highest with a weighted score of 640 which is 84 percent of the possible weighted score. The remaining 3 items in this group had a range of weighted scores from 631 to 613 . Item 13, Motivating Students to Learn on Their Own, and item 45, Transforming Faith into Action--by Vicarious Experience--Developing Christian Values 
TABLE 5

RANKED ITEMS FOR ALL ELEMENTARY LAKE UNION CONFERENCE TEACHERS

\begin{tabular}{|c|c|c|c|c|c|c|c|c|}
\hline $\begin{array}{l}\text { Item } \\
\text { Number }\end{array}$ & Inservice Needs & $\begin{array}{l}\text { Rank } \\
\text { Order }\end{array}$ & $\begin{array}{l}\text { Weighted } \\
\text { Score }\end{array}$ & $\begin{array}{r}\text { Raw } \\
\text { SD-1 }\end{array}$ & $\begin{array}{l}\text { Score } \\
\text { D-2 }\end{array}$ & S $(\operatorname{Re}$ & $\begin{array}{l}\text { spons } \\
\text { A-4 }\end{array}$ & $\begin{array}{l}\text { es) } \\
\text { SA-5 }\end{array}$ \\
\hline 46 & Making Bible more applicable to everyday life & 1 & 640 & 003 & 015 & 007 & 054 & 074 \\
\hline 39 & $\begin{array}{l}\text { Instilling in the student the will to learn } \\
\text { on his own initiative }\end{array}$ & 2 & 631 & 004 & 012 & 009 & 064 & 064 \\
\hline 13 & Motivating students to learn on their own & 3 & 613 & 003 & 014 & 015 & 068 & 053 \\
\hline 45 & $\begin{array}{l}\text { Transforming faith into action by vicarious } \\
\text { experience-developing Christian values } \\
\text { and attitudes }\end{array}$ & 4 & 613 & 003 & 011 & 019 & 069 & 051 \\
\hline 38 & Stimulating growth of pupil attitudes and values & 5 & 605 & 004 & 013 & 014 & 077 & 045 \\
\hline 44 & $\begin{array}{l}\text { Constructing and implementing a Christian } \\
\text { witnessing program for students and } \\
\text { teachers together }\end{array}$ & 6 & 604 & 004 & 014 & 019 & 065 & 051 \\
\hline 01 & Dlagnosing basic learning difficulttes & 7 & 599 & 004 & 015 & 013 & 079 & 042 \\
\hline 42 & $\begin{array}{l}\text { Developing a better understanding of the theory } \\
\text { of IFLP and what makes it work }\end{array}$ & 8 & 595 & 005 & 014 & 022 & 064 & 043 \\
\hline 09 & $\begin{array}{l}\text { Developing the use of the computer in the } \\
\text { classroom }\end{array}$ & 9 & 583 & 009 & 012 & 034 & 042 & 056 \\
\hline 35 & Facilitating pupil self-concept and worth & 10 & 581 & 003 & 020 & 014 & 084 & 032 \\
\hline 11 & Creating useful remedial materials & 11 & 579 & 003 & 024 & 017 & 068 & 041 \\
\hline 37 & Facilitating development of pupil responsibility & 12 & 577 & 004 & 018 & 021 & 076 & 034 \\
\hline 03 & $\begin{array}{l}\text { Identifying student disabilities that need } \\
\text { referral or special remedial work }\end{array}$ & 13 & 573 & 002 & 031 & 013 & 065 & 042 \\
\hline
\end{tabular}


TABLE 5--Continued

\begin{tabular}{|c|c|c|c|c|c|c|c|c|}
\hline $\begin{array}{l}\text { I tem } \\
\text { Number }\end{array}$ & Inservice Needs & $\begin{array}{r}\text { Rank } \\
\text { Order }\end{array}$ & $\begin{array}{l}\text { Weighted } \\
\text { Score }\end{array}$ & $\begin{array}{r}\text { Raw } \\
\text { SD-1 }\end{array}$ & $\begin{array}{l}\text { Scores } \\
0-2\end{array}$ & $\begin{array}{c}\text { S } \\
U-3\end{array}$ & $\begin{array}{l}\text { spons } \\
A-4\end{array}$ & es) \\
\hline 15 & $\begin{array}{l}\text { Selecting and developing materials-activities } \\
\text { appropriate for individualized instruction }\end{array}$ & 14 & 567 & 004 & 022 & 019 & 078 & 030 \\
\hline 26 & $\begin{array}{l}\text { Usizul methods of classroom discipline and } \\
\text { when to use them }\end{array}$ & 15 & 562 & 005 & 030 & 015 & 063 & 040 \\
\hline 16 & $\begin{array}{l}\text { Implementing and supervising individualized } \\
\text { instruction }\end{array}$ & 16 & 562 & 004 & 023 & 017 & 084 & 025 \\
\hline 14 & $\begin{array}{l}\text { Keeping abreast of developments in your own } \\
\text { subject area }\end{array}$ & 17 & 561 & 001 & 029 & 023 & 067 & 033 \\
\hline 43 & $\begin{array}{l}\text { Knowing how to achieve IFLP from the curriculum } \\
\text { through written objectives and evaluation }\end{array}$ & 18 & 560 & 009 & 018 & 025 & 065 & 036 \\
\hline 30 & Involving others in the school program & 19 & 548 & 003 & 021 & 031 & 080 & 018 \\
\hline 19 & Gearing instruction to problem solving & 20 & 543 & 003 & 026 & 029 & 074 & 021 \\
\hline 23 & $\begin{array}{l}\text { Constructively using evaluation in helping } \\
\text { student progress }\end{array}$ & 21 & 542 & 002 & 027 & 029 & 076 & 019 \\
\hline 28 & Communicating and interacting with parents & 22 & 541 & 007 & 033 & 013 & 071 & 029 \\
\hline 27 & Maintaining classroom control without... & 23 & 540 & 005 & 030 & 015 & 063 & 040 \\
\hline 24 & $\begin{array}{l}\text { Managing classroom affairs in order to get } \\
\text { maximum benefit from supervising aides, } \\
\text { tutors, and etc. }\end{array}$ & 24 & 540 & 004 & 032 & 025 & 063 & 029 \\
\hline 29 & Counseling and conferring with students & 25 & 539 & 005 & 033 & 017 & 073 & 025 \\
\hline 31 & Developing a persunal self-evaluation method & 26 & 537 & 004 & 028 & 030 & 068 & 023 \\
\hline 25 & $\begin{array}{l}\text { Knowing where to refer student problems } \\
\text { beyond what can be handled by the teacher }\end{array}$ & 27 & 533 & 007 & 035 & 021 & 057 & 033 \\
\hline
\end{tabular}


TABLE 5--Continued

\begin{tabular}{|c|c|c|c|c|c|c|c|c|}
\hline $\begin{array}{l}\text { Item } \\
\text { Number }\end{array}$ & Inservice Needs & $\begin{array}{l}\text { Rank } \\
\text { Order }\end{array}$ & $\begin{array}{l}\text { Weighted } \\
\text { Score }\end{array}$ & $\begin{array}{r}\text { Saw } \\
\text { SD-1 }\end{array}$ & $\begin{array}{l}\text { Scores } \\
\text { D-2 }\end{array}$ & $5(\operatorname{Re}$ & $\begin{array}{l}\text { spons } \\
\text { A-4 }\end{array}$ & SA-5 \\
\hline 36 & Facilitating pupil social interaction & 28 & 532 & 004 & 027 & 030 & 076 & 016 \\
\hline 40 & $\begin{array}{l}\text { Developing or modifying instructional pro- } \\
\text { cedures to suit your own strengths }\end{array}$ & 29 & 531 & 005 & 027 & 031 & 071 & 019 \\
\hline 04 & $\begin{array}{l}\text { Identifying student attitudes in order to } \\
\text { better relate to problems }\end{array}$ & 30 & 525 & 007 & 031 & 021 & 077 & 017 \\
\hline 10 & $\begin{array}{l}\text { Planning teaching activities with other } \\
\text { teachers or administrators }\end{array}$ & 31 & 522 & 005 & 037 & 027 & 058 & 026 \\
\hline 17 & $\begin{array}{l}\text { Using questioning procedures that promote } \\
\text { discussion }\end{array}$ & 32 & 521 & 010 & 034 & 017 & 068 & 024 \\
\hline 06 & Involving students in self evaluation & 33 & 518 & 006 & 031 & 028 & 074 & 014 \\
\hline 12 & Evaluating instruction/instructional design & 34 & 514 & 001 & 032 & 044 & 063 & 013 \\
\hline 32 & Developing a broad acceptance of self & 25 & 511 & 008 & 034 & 032 & 056 & 023 \\
\hline 21 & Providing for reinforcement & 36 & 509 & 006 & 036 & 030 & 064 & 017 \\
\hline 41 & Identifying the gifted and talented student & 37 & 504 & 007 & 036 & 031 & 063 & 016 \\
\hline 08 & $\begin{array}{l}\text { Deciding what teaching techniques is best } \\
\text { for a particular intended outcome }\end{array}$ & 38 & 501 & 005 & 036 & 030 & 076 & 006 \\
\hline 02 & $\begin{array}{l}\text { Constructing and using tests for evaluating } \\
\text { academic progress }\end{array}$ & 39 & 495 & 008 & 040 & 027 & 061 & 014 \\
\hline 34 & $\begin{array}{l}\text { Developing a capacity of accepting others' } \\
\text { feelings }\end{array}$ & 40 & 494 & 010 & 041 & 026 & 056 & 020 \\
\hline
\end{tabular}


TABLE 5--Continued

\begin{tabular}{|c|c|c|c|c|c|c|c|c|}
\hline $\begin{array}{l}\text { I tem } \\
\text { Number }\end{array}$ & Inservice Needs & $\begin{array}{r}\text { Rank } \\
\text { Order }\end{array}$ & $\begin{array}{l}\text { Weighted } \\
\text { Score }\end{array}$ & $\begin{array}{l}\text { Raw } \\
\text { SD-1 }\end{array}$ & $\begin{array}{c}\text { Score } \\
D-2\end{array}$ & $\begin{array}{l}\text { s } \\
U-3\end{array}$ & $\begin{array}{l}\text { sponse } \\
\text { A-4 }\end{array}$ & $\begin{array}{l}\text { es) } \\
\text { SA-5 }\end{array}$ \\
\hline 33 & $\begin{array}{l}\text { Selecting and specifying performance goals } \\
\text { and objectives }\end{array}$ & 41 & 494 & 006 & 040 & 034 & 059 & 014 \\
\hline 18 & $\begin{array}{l}\text { Utflization of audio-visual equipment and } \\
\text { other mechanical aids }\end{array}$ & 42 & 492 & 010 & 043 & 021 & 062 & 017 \\
\hline 06 & Involving students in self evaluation & 43 & 491 & 005 & 042 & 034 & 060 & 012 \\
\hline 22 & $\begin{array}{l}\text { Deciding on appropriate pupil grouping } \\
\text { procedures for instruction }\end{array}$ & 44 & 482 & 005 & 052 & 029 & 049 & 018 \\
\hline 07 & Teacher-pupil verbal interaction & 45 & 461 & 013 & 047 & 025 & 061 & 007 \\
\hline 20 & $\begin{array}{l}\text { General presentation of information and } \\
\text { directions }\end{array}$ & 46 & 433 & 015 & 058 & 026 & 046 & 008 \\
\hline
\end{tabular}


and Attitudes, had the same weighted score of 613 . Item 46 and item 39, Instilling in the Student the Will to Learn on His Own Initiative, had the same totalled agree and strongly agreed responses (128). Of the 4 items in this group, 2 were from category IX, Integration of Faith, Learning, and Practice, and 2 were from category II, Development of Personal Self.

The next group of 22 items was between the 79-70 percent level of the possible weighted score of 765 with the weighted scores ranging from 605 to 537. Item 38, Stimulating Growth of Pupil Attitudes and Values, ranked first in this percentage group with item 44, Constructing and Implementing a Christian Witness Program for Students and Teachers Together, ranked second with weighted scores differing by only 1 point. The range between the items was from 1 to 12 points. Items were clustered together with a 1 to 2 point spread while other items had the same scores. Item 26 , Useful Methods of Classroom Discipline and When to Use Them, and item 16, Implementing and Supervising Individualized Instruction, had the same weighted scores of 562 . Such was the same with item 27. Maintaining Classroom Control without Appearing as an Ogre to the Students, and item 24, Managing Classroom Affairs in Order to Get Maximum Benefit from Supervising, Aids, Tutors, etc. They each had weighted scores of 540 . Item 35, Facilitating Pupil Self-Concept and Worth, and item 16, Implementing and Supervising Individualized Instruction, both had 84 agreed responses. Item 9, Developing the Use of the Computer in the Classroom, had the highest strongly agreed with 56 responses in this percentage 
group, as well as the highest number of undecided responses (34). The items in this group fell into all the nine categories except Assessment and Classroom Management.

The next 19 items were between the 69 and 60 percentage level of the possible weighted score of 765 with weighted scores ranging from 533 to 461 . The range between the weighted scores was from 1 to 9 points except for a range of 21 points between the last 2 items. Several items had the same number of responses such as item 36, Facilitating Pupil Social Interaction, and item 40, Developing or Modifying Instructional Procedures to Suit Your Own Strengths, each had 27 disagreed responses. Item 17, Using Questioning Procedures that Promote Discussion, had 34 disagreed responses as did item 12, Evaluating Instruction/Instructional Design. Item 21 , Providing for Reinforcement, item 41, Identifying the Gifted and Talented Students, and item 8, Deciding What Teaching Technique is Best for a Particular Intended Outcome, rod 36 disagreed responses each. Item 2, Constructing and Using Tests for Evaluating Academic Progress, and item 33, Selecting and Specifying Performance Goals and Objectives, had the highest undecided with 44 responses. The responses in this group fell into all of the nine categories except category III, Individualized Instruction, and category $V$, Discipline.

The last and fourth group consisted of item 20, General Presentation of Information and Directions, ranking last with a weighted score of 433 . This score was below the 60 percent level of the possible weighted score of 765 . This item comes under the category of Classroom Management. 
Forty-five items of the questionnaire were above the 60 percent level of the possible weighted score. Twenty-six were above the 70 percent level, while four were above the 80 percent level of the possible weighted score of 765 .

The top four perceived inservice needs of the elementary teachers $(K-8)$ of the Lake Union Conference were as follows:

1. Making Bible Instruction More Applicable to Everyday Life

2. Instilling in the Student the will to Learn on His Own Initiative

3. Motivating the Students to Learn on Their Own

4. Transforming Faith Into Action--by Vicarious Experience-Developing Christian Values and Attitudes.

Items 1 and 4 were from Category IX, Integration of Faith, Learning, and Practice, while items 2 and 3 were from Category II, Developing Pupil Self.

Ranked Categories--El ementary Teachers

The description of the categories is presented in ranked order (table 6). Likewise, the description of the items within the categories is presented in ranked order, according to the responses (table 7 ).

Category IX, Integration of Faith, Learning, and Practice, ranked first among the nine categories. Item 46, Making Bible Instruction More Applicable to Everyday Life, ranked first in the category with 74 strongly agreed responses. Both items 45, Transforming Faith into Action--by Vicarious Experience--Developing Christian Values and Attitudes, and 44 , Constructing and Implementing a Christian Witnessing Program for Students and Teachers Together, had the same 
TABLE 6

RANKED CATEGORIES FOR ALL ELEMENTARY LAKE UNION CONFERENCE TEACHERS

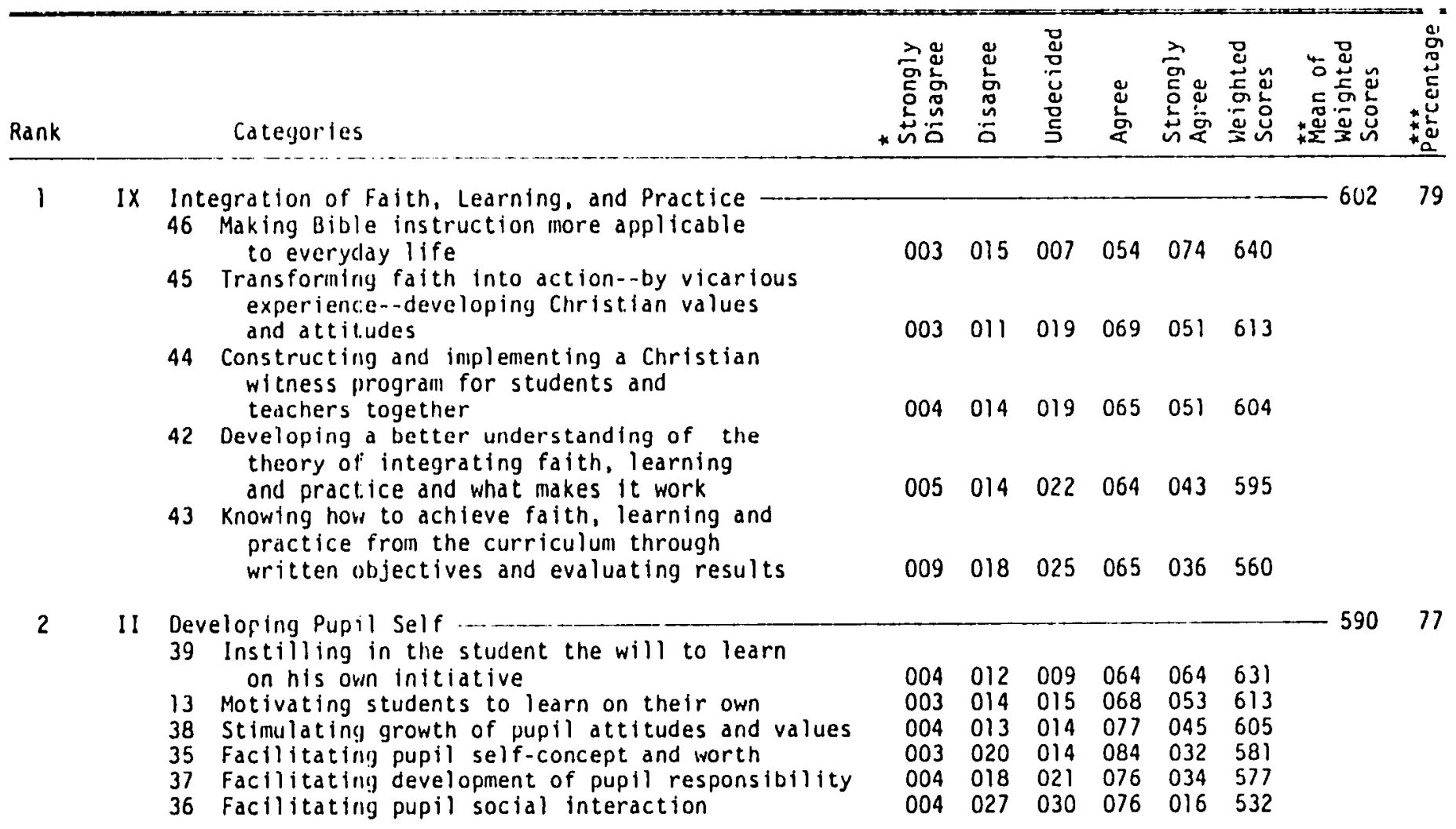


TABLE 6--Continued

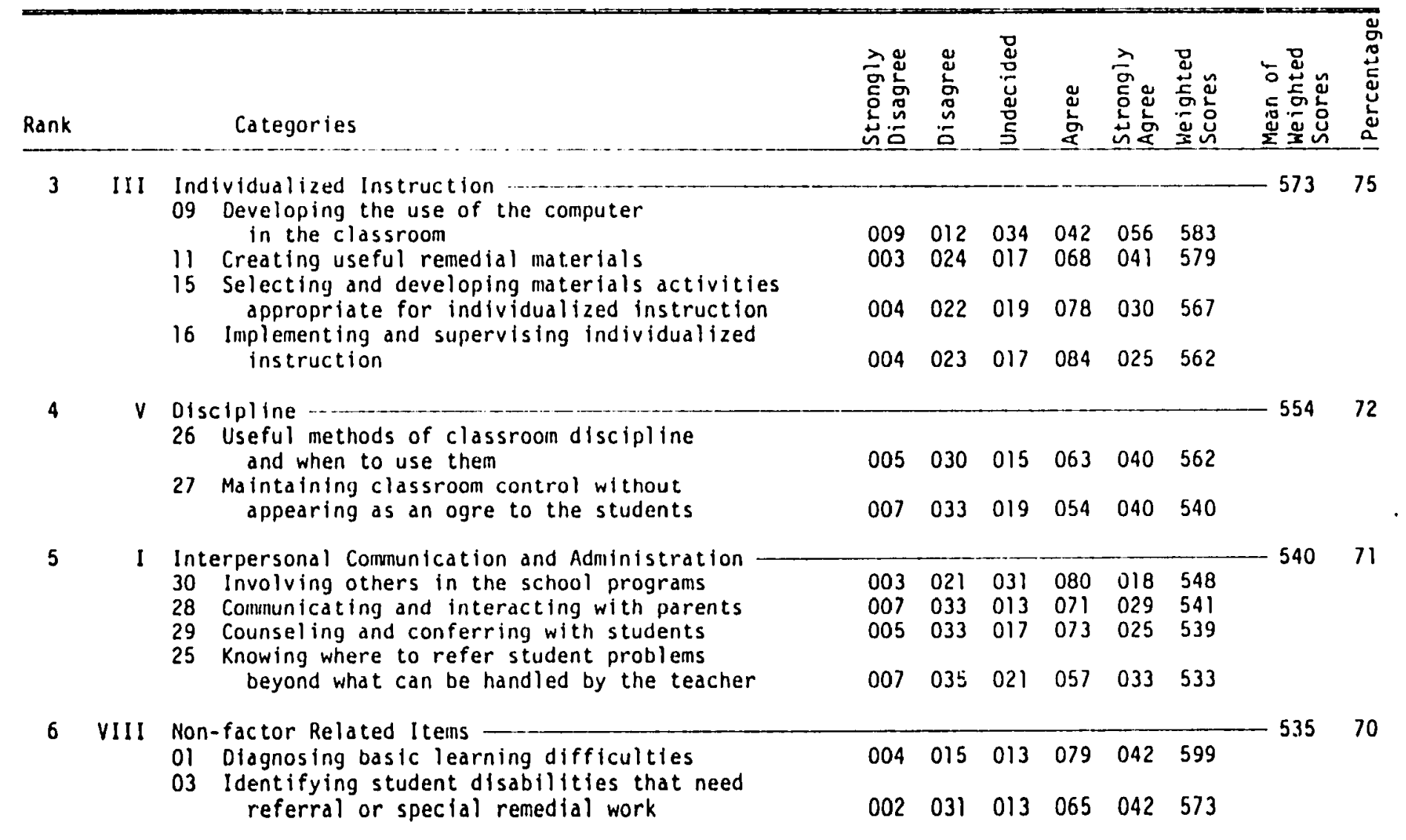


TABLE 6--Continued

\begin{tabular}{|c|c|c|c|c|c|c|c|c|c|}
\hline $\operatorname{Ran}:$ & Categories & 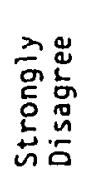 & $\begin{array}{l}\stackrel{0}{0} \\
\frac{1}{0} \\
0 \\
n \\
0 \\
0\end{array}$ & 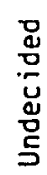 & 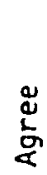 & 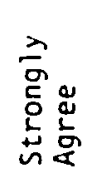 & 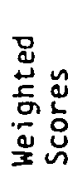 & 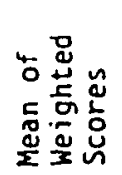 & 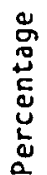 \\
\hline
\end{tabular}

14 Keeping abreast of developinents in your own subject matter area

19 Gearing instruction to problem solving

23 Constructively using evaluation in helping student progress

24 Managing'classroon affairs in order to get maximum benefit from supervising, aids.

$$
\text { tutors, etc. }
$$

04 Identifying student attitudes in order to better relate to problems

10 Planning teaching activities with other teachers or administrators

17 Using questioning procedures that

$$
\text { promote discussion }
$$

41 Identifying the gifted and talented students

08 Deciding what teaching technique is best for a particular intended outcome

18 Utilization of audio-visual equipment and other mechanical aids

$\begin{array}{llllll}001 & 029 & 023 & 067 & 033 & 561\end{array}$

$\begin{array}{llllll}003 & 026 & 029 & 074 & 021 & 543\end{array}$

$\begin{array}{llllll}002 & 027 & 029 & 076 & 019 & 542\end{array}$

$\begin{array}{llllll}004 & 032 & 025 & 063 & 029 & 540\end{array}$

$\begin{array}{llllll}007 & 031 & 021 & 077 & 017 & 525\end{array}$

$\begin{array}{llllll}005 & 037 & 027 & 058 & 026 & 522\end{array}$

$\begin{array}{llllll}010 & 034 & 017 & 068 & 024 & 521\end{array}$

$\begin{array}{llllll}007 & 036 & 03 ! & 063 & 016 & 504\end{array}$

$\begin{array}{llllll}005 & 036 & 030 & 076 & 006 & 501\end{array}$

$\begin{array}{llllll}010 & 043 & 021 & 062 & 017 & 492\end{array}$

$\begin{array}{llllll}004 & 028 & 030 & 068 & 023 & 537\end{array}$

$\begin{array}{llllll}008 & 034 & 032 & 056 & 023 & 511\end{array}$

31 Developing a personal self-evaluation method

32 Developing a broad acceptance of self

34 Developing a capacity of accepting others feelings

$\begin{array}{llllll}010 & 041 & 026 & 056 & 020 & 494\end{array}$ 
TABLE 6--Continued

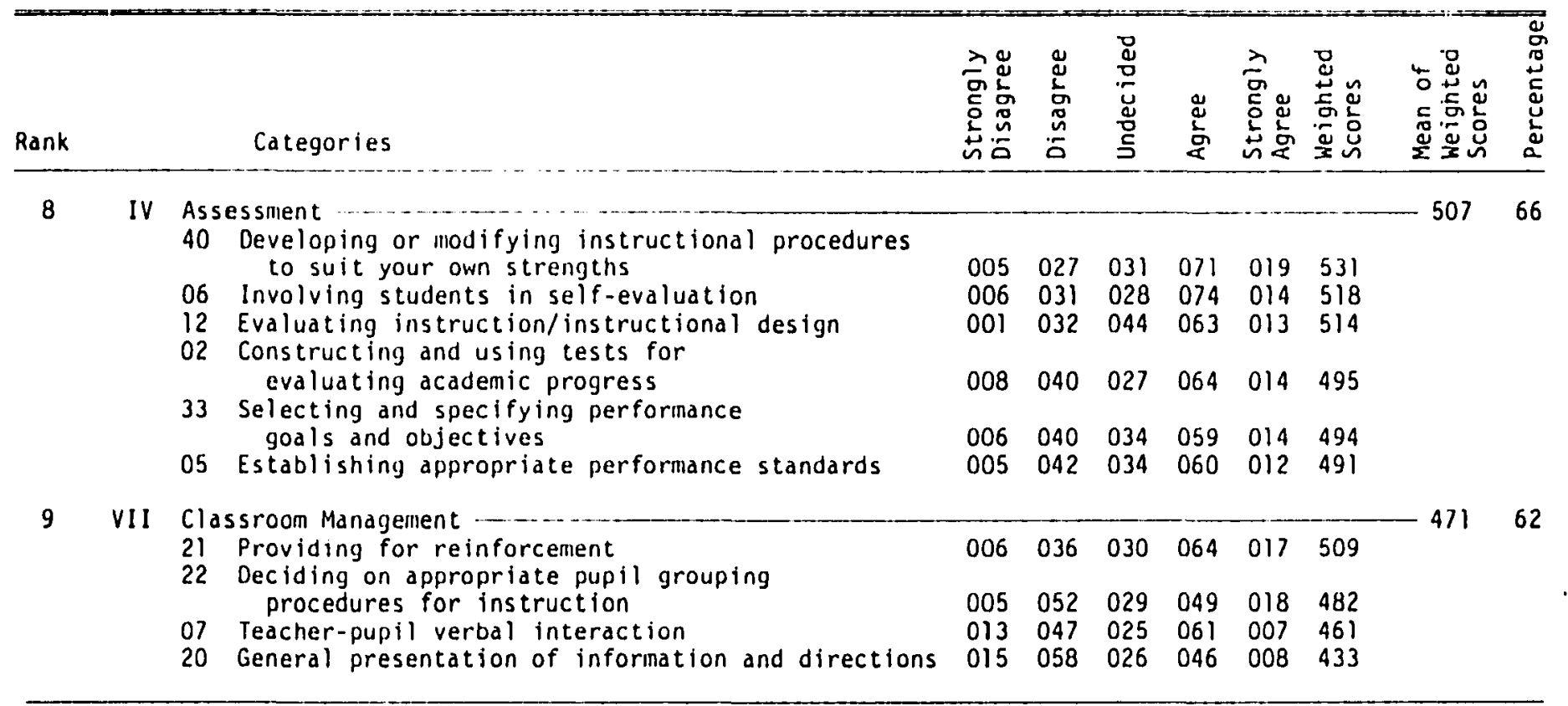

* Raw Scores

** Mean of the weighted score for the category

$\star \star \star *$ Percent of the possible weighted score 
TABLE 7

A SUMMARY OF THE RANKED CATEGORIES FOR ALL ELEMENTARY LAKE UNION CONFERENCE TEACHERS

\begin{tabular}{llll}
\hline \multicolumn{1}{c}{ Categories } & $\begin{array}{c}\text { Mean of } \\
\text { Ranking } \\
\text { Order }\end{array}$ & $\begin{array}{c}\text { Percentage } \\
\text { Weighted } \\
\text { Score* }\end{array}$ & $\begin{array}{c}\text { Weighted } \\
\text { Score }\end{array}$ \\
\hline IX Integration of Faith, Learning, and Prätice & 1 & 602 & 79 \\
II Developing Pupil Self & 2 & 590 & 77 \\
III Individualized Instruction & 3 & 573 & 75 \\
V Discipline & 4 & 554 & 72 \\
I Interpersonal Communication and Adininistration & 5 & 540 & 71 \\
VIII Non-factor Related Item & 6 & 535 & 67 \\
VI Developing Personal Self & 7 & 514 & 66 \\
IV Assessment & 8 & 507 & 62 \\
VII Classroom Mariagement & 9 & 471 \\
\hline
\end{tabular}

*Maximum weighted score for this table was 765 [five times the number of teachers in the group]. 
number of strongly agreed responses (51) and the same number of undecided responses (19). Item 44 and item 43, Knowing How to Achieve Faith, Learning and Practice from the Curriculum through Written Objectives and Evaluating Results, had the same number of 65 agreed responses. Category IX consisted of 5 questionnaire items--42, 43, 44, 45, and 46. The mean score of 602 , shown in table 7, was 79 percent of the possible weighted score of 765 . Category II, Developing Pupil Self, ranked second among the nine categories. Item 39, Instilling in the Student the will to Learn on His Own Initiative, ranked first in the category with both agree and strongly agree having 64 responses. Item 35, Facilitating Pupil Self-Concept and Worth had the highest number of agree with 84 responses. Item 36 , Facilitating Pupil Social the highest number of undecided responses (30). Category II consisted of 6 questionnaire items $--13,35,36,37,38$, and 39 . The mean score of 590, shown in table 7 , was 77 percent of the possible weighted score of 765 .

Category III, Individualized Instruction, ranked third among the nine categories. Item 9, Developing the Use of the Computer in the Classroom, ranked first in the category with 98 totally agreed and strongly agreed responses. However, item 11 , Creating Useful Remedial Materials, and item 16, Implementing and Supervising Individualized Instruction, both had 109 totally agreed and strongly agreed responses. Both items 11 and 16 also had the highest number of disagreed responses. Category III consisted of 4 questionnaire items--9, 11, 15, and 16. The mean score of 573, shown in table 7 , was 75 percent of the possible weighted score of 765 . 
Category V, Discipline, ranked fourth among the nine categories. Item 26, Useful Methods of Classroom Discipline and When to Use Them, ranked first in the category with 103 totalled agree and strongly agreed responses. Item 27 , Maintaining Classroom Control without Appearing as an Ogre to the Students, ranked second. However, both items had the same number of strongly agreed responses (40). Category $V$ consisted of 2 questionnaire items--26 and 27 . The mean score of 554, shown in table 7 , was 72 percent of the possible weighted score of 765 .

Category I, Interpersonal Communication and Administration, ranked fifth among the nine categories. Item 30, Involving Others in the School Program, ranked first in the category with 80 agreed responses. Item 28, Communicating and Interacting with Parents, ranked second. Item 25, Knowing Where to Refer Student Problems beyond What Can be Handled by the Teacher, ranked last in the category with the highest strongly agree responses (33) and disagree responses (35). Category I consisted of 4 questionnaire items- $-25,28,29$, and 30 . The mean score of 540 , shown in table 7 , was 71 percent of the possible weighted score of 765 .

Category VIII, Non-factor Related Items, ranked sixth among the nine categories. Item 1, Diagnosing Basic Learning Difficulties, ranked first in the category with 79 agreed responses. Item 3, Identifying Student Disabilities that Need Referral or Special Remedial Work, ranked second. Both items 1 and 3 had the same number of strongly agreed (42) and undecided (13) responses. Item 18, Utilization of Audio-Visual Equipment and Other Mechanical Aids, ranked last in the category with 43 disagree responses. Category VIII 
consisted of 12 questionnaire items--1, 3, 4, 8, 10, 14, 17, 18, $19,23,24$, and 41 . The mean score of 535 , shown in table 7 , was 70 percent of the possible weighted score of 765 .

Category VI, Developing Personal Self, ranked seventh among the nine categories. Item 31, Developing a Personal SelfEvaluation Method, ranked first in the category with 68 agreed responses. Item 32, Developing a Broad Acceptance of Self, ranked second. Both items 31 and 32 had the same number of strongly agreed responses (23). Likewise, item 32 and item 24, Developing a Capacity of Accepting Others' Feelings, had the same number of agreed responses (56). Item 34, ranked last in the category. Category VI consisted of 3 questionnaire items--31, 32, and 34 . The mean score of 514 , shown in table 7 , was 67 percent of the possible weighted score of 765 .

Category IV, Assessment, ranked seventh among the nine categories. Item 40, Developing or Modifying Instructional Procedures to Suit Your Own Strengths, ranked first in the category with a total of 90 agreed and strongly agreed responses. Item 6, Involvirig Students in Self-Evaluation, ranked second with 74 agreed responses. Item 2, Constructing and Using Tests for Evaluating Academic Progress, and item 33, Selecting and Specifying Performance Goals and objectives, had the same number of disagreed responses (40). Item 5 , Establishing Appropriate Performance Standards, raniked last with 42 disagreed responses. Category IV consisted of 6 questionnaire items--2, 5, 6, 12, 33, and 40. The mean score of 507 , shown in table 7, was 66 percent of the possible weighted score of 765 . 
Category VII, Classroom Management, ranked last out of the nine categories. Item 21, Providing for Reinforcement ranked highest in the category with 64 agreed responses. Item 22, Deciding on Appropriate Pupil Grouping Procedures for Instruction, ranked second. Item 20, General Presentation of Information and Directions ranked last in the category with 58 disagree responses. Category VII consisted of 4 questionnaire items, $7,20,21$, and 22 . The mean score of 471 , shown in table 7 , was 62 percent of the possible weighted score of 765 .

\section{Ranked Items--Secondary Teachers}

The description of the items is presented in ranked order and put into percentage groups. By ranking the items it was found there were 7 items which scored between 89-80 percent of the possible weighted score of 315 (63 teachers $\times 5)$ (table 8). Item 13, Motivating Students to Learn on Their Own, ranked the highest with a weighted score of 273 which was 87 percent of the possible weighted score. The remaining 6 items in this percentage group had a range of weighted scores from 269 to 253. Item 14, Keeping Abreast of Developments in Your Own Subject Matter Area, ranked second with the highest number of strongly agreed responses (36). There were 5 items in this percentage group which had the same totalled number of agreed and strongly agreed responses (53). They were: item 46, Making Bible Instruction More Applicable to Everyday Life; item 45, Transforming Faith into Action--by Vicarious Experience-Developing Christian Values and Attitudes; item 44, Constructing and Implementing a Christian Witness Program for Students and Teachers Together; item 39, Instilling in the Student the Will to Learn on His 
TABLE 8

RANKED ITEMS FOR ALL SECONDARY LAKE UNION CONFERENCE TEACHERS

\begin{tabular}{|c|c|c|c|c|c|c|c|c|}
\hline $\begin{array}{l}\text { Item } \\
\text { Number }\end{array}$ & Inservice Needs & $\begin{array}{l}\text { Rank } \\
\text { Order }\end{array}$ & $\begin{array}{l}\text { Weighted } \\
\text { Score }\end{array}$ & $\begin{array}{r}\text { Raw } \\
S D-1\end{array}$ & $\begin{array}{c}\text { Score } \\
0-2\end{array}$ & $5(\operatorname{Re}$ & $\begin{array}{c}\text { spons } \\
A-4\end{array}$ & SA-5 \\
\hline 13 & Notivating students to learn on their own & 1 & 273 & 000 & 003 & 003 & 027 & 030 \\
\hline 14 & $\begin{array}{l}\text { Keeping abreast of developments in your own } \\
\text { subject area }\end{array}$ & 2 & 269 & 003 & 005 & 000 & 019 & 036 \\
\hline 46 & Naking Bible more applicable to everyday life & 3 & 264 & 002 & 003 & 004 & 024 & 029 \\
\hline 45 & $\begin{array}{l}\text { "ransforming faith into action by vicarious } \\
\text { experience-developing Christian values } \\
\text { and attitudes }\end{array}$ & 4 & 259 & 002 & 005 & 003 & 027 & 026 \\
\hline 44 & $\begin{array}{l}\text { Constructing and implementing a Christian } \\
\text { witnessing program for students and } \\
\text { teachers together }\end{array}$ & 5 & 259 & 002 & 003 & 005 & 029 & 024 \\
\hline 39 & $\begin{array}{l}\text { Instilling in the student the will to learn } \\
\text { on his own initiative }\end{array}$ & 6 & 258 & 002 & 005 & 004 & 026 & 027 \\
\hline 38 & $\begin{array}{l}\text { Stimulating growth of pupil attitudes and } \\
\text { values }\end{array}$ & 7 & 253 & 002 & 005 & 003 & 033 & 020 \\
\hline 42 & $\begin{array}{l}\text { Developing a better understanding of the theory } \\
\text { of IFLP and what makes it work }\end{array}$ & 8 & 251 & 001 & 007 & 008 & 023 & 024 \\
\hline 35 & Factlitating pupil self-concept and worth & 9 & 247 & 002 & 008 & 004 & 028 & 021 \\
\hline 23 & $\begin{array}{l}\text { Constructively using evaluation in helping } \\
\text { student progress }\end{array}$ & 10 & 245 & 001 & 003 & 012 & 033 & 014 \\
\hline
\end{tabular}


TABLE 8--Continued

\begin{tabular}{|c|c|c|c|c|c|c|c|c|}
\hline $\begin{array}{l}\text { Item } \\
\text { Number }\end{array}$ & Inservice Needs & $\begin{array}{r}\text { Rank } \\
\text { Order }\end{array}$ & $\begin{array}{l}\text { Weighted } \\
\text { Score }\end{array}$ & $\begin{array}{r}\text { Raw } \\
S D-1\end{array}$ & $\begin{array}{l}\text { Scores } \\
0-2\end{array}$ & $S \underset{U-3}{(\operatorname{Re}}$ & $\begin{array}{l}\text { spons } \\
A-4\end{array}$ & $\begin{array}{l}\text { es) } \\
\text { SA-5 }\end{array}$ \\
\hline 09 & $\begin{array}{l}\text { lieveloping the use of the computer in the } \\
\text { classroom }\end{array}$ & 11 & 242 & 002 & 008 & 004 & 019 & 023 \\
\hline 19 & Ciearing instruction to problem solving & 12 & 241 & 001 & 007 & 006 & 037 & 012 \\
\hline 37 & Facilitating development of pupil responsibility & 13 & 240 & 003 & 008 & 008 & 023 & 021 \\
\hline 43 & $\begin{array}{l}\text { knowing how to achieve IFLP from the curriculum } \\
\text { through written objectives and evaluation }\end{array}$ & 14 & 239 & 002 & 008 & 008 & 028 & 017 \\
\hline 15 & $\begin{array}{l}\text { Selecting and developing materials-activities } \\
\text { appropriate for individualized instruction }\end{array}$ & 15 & 236 & 002 & 005 & 013 & 030 & 013 \\
\hline 01 & Diagnosing basic learning difficulties & 16 & 235 & 002 & 007 & 011 & 039 & 014 \\
\hline 26 & $\begin{array}{l}\text { Useful methods of classroom discipline and } \\
\text { when to use them }\end{array}$ & 17 & 235 & 005 & 005 & 005 & 035 & 013 \\
\hline 17 & $\begin{array}{l}\text { Using questioning procedures that promote } \\
\text { discussion }\end{array}$ & 18 & 233 & 002 & 007 & 013 & 027 & 014 \\
\hline 04 & $\begin{array}{l}\text { Identifying student attitudes in order to } \\
\text { better relate to problems }\end{array}$ & 19 & 232 & 002 & 011 & 011 & 020 & 019 \\
\hline 29 & Counseling and conferring with students & 20 & 231 & 004 & 010 & 005 & 028 & 016 \\
\hline 31 & Developing a personal self-evaluation method & 21 & 230 & 004 & 006 & 010 & 031 & 012 \\
\hline 06 & Involving students in self evaluation & 22 & 230 & 003 & 005 & 011 & 036 & 008 \\
\hline 40 & $\begin{array}{l}\text { Developing or modifying instructional pro- } \\
\text { cedures to suit your own strengths }\end{array}$ & 23 & 229 & 002 & 009 & 012 & 027 & 013 \\
\hline 27 & Maintaining classroom control without. & 24 & 228 & 004 & 010 & 004 & 029 & 015 \\
\hline
\end{tabular}


TABLE 8-- Continued

\begin{tabular}{|c|c|c|c|c|c|c|c|c|}
\hline $\begin{array}{l}\text { Item } \\
\text { Number }\end{array}$ & Inservice Needs & $\begin{array}{l}\text { Rank } \\
\text { Order }\end{array}$ & $\begin{array}{l}\text { Weighted } \\
\text { Score }\end{array}$ & $\begin{array}{l}\text { Raw } \\
\text { SD-1 }\end{array}$ & $\begin{array}{l}\text { Score } \\
\text { D-2 }\end{array}$ & $S(\operatorname{Re}$ & $\begin{array}{l}\text { spons } \\
\text { A-4 }\end{array}$ & $\begin{array}{l}\text { es) } \\
\text { SA-5 }\end{array}$ \\
\hline 03 & $\begin{array}{l}\text { Identifying student disabilities that need } \\
\text { referral of special remedial work }\end{array}$ & 25 & 227 & 001 & 009 & 014 & 029 & 010 \\
\hline 08 & $\begin{array}{l}\text { Deciding what teaching techniques is best } \\
\text { for a particular intended outcome }\end{array}$ & 26 & 22.5 & 003 & 011 & 008 & 029 & 012 \\
\hline 10 & $\begin{array}{l}\text { Planning teaching activities with other } \\
\text { teachers or administrators }\end{array}$ & 27 & 22.5 & 004 & 011 & 008 & 029 & 010 \\
\hline 11 & Creating useful remedial materials & 28 & 221 & 003 & 010 & 014 & 024 & 012 \\
\hline 32 & Developing a broad acceptance of self & 29 & 220 & 005 & 008 & 014 & 023 & 013 \\
\hline 16 & $\begin{array}{l}\text { Implementing and supervising individualized } \\
\text { instruction }\end{array}$ & 30 & 220 & 003 & 007 & 019 & 024 & 010 \\
\hline 28 & Communicating and interacting with parents & 31 & 215 & 005 & 015 & 006 & 023 & 014 \\
\hline 33 & $\begin{array}{l}\text { Selecting and specifying performance goals } \\
\text { and objectives }\end{array}$ & 32 & 215 & 004 & 006 & 018 & 030 & 005 \\
\hline 12 & Evaluating instruction/instructional design & 33 & 215 & 003 & 007 & 017 & 033 & 003 \\
\hline 07 & Teacher-pupil verbal interaction & 34 & 212 & 004 & 013 & 011 & 026 & 009 \\
\hline 30 & Involving others in the school program & 35 & 210 & 005 & 006 & 020 & 027 & 005 \\
\hline 34 & $\begin{array}{l}\text { Developing a capacity of accepting others' } \\
\text { feelings }\end{array}$ & 36 & 209 & 005 & 012 & 014 & 022 & 010 \\
\hline 05 & Establishing appropriate performance standards & 37 & 209 & 002 & 015 & 013 & 027 & 006 \\
\hline 21 & Providing for reinforcement & 38 & 206 & 005 & 012 & 017 & 019 & 010 \\
\hline
\end{tabular}


TABLE 8--Continued

\begin{tabular}{|c|c|c|c|c|c|c|c|c|}
\hline $\begin{array}{l}\text { Item } \\
\text { Number }\end{array}$ & Inservice Needs & $\begin{array}{r}\text { Rank } \\
\text { Order }\end{array}$ & $\begin{array}{l}\text { Weighted } \\
\text { Score }\end{array}$ & $\begin{array}{l}\text { Raw } \\
\text { SD-1 }\end{array}$ & $\begin{array}{l}\text { Scores } \\
D-2\end{array}$ & $5 \underset{U-3}{(\operatorname{Re}}$ & $\begin{array}{l}\text { sponse } \\
\text { A-4 }\end{array}$ & $\begin{array}{l}\text { es) } \\
\text { SA-5 }\end{array}$ \\
\hline 36 & Facilitating pupil social interaction & 39 & 206 & 003 & 015 & 014 & 024 & 007 \\
\hline 02 & $\begin{array}{l}\text { Constructing and using tests for evaluating } \\
\text { academic progress }\end{array}$ & 40 & 206 & 004 & 019 & 004 & 028 & 008 \\
\hline 25 & $\begin{array}{l}\text { Knowing where to refer student problems } \\
\text { beyond what can be handled by the teacher }\end{array}$ & 41 & 205 & 007 & 011 & 013 & 023 & 009 \\
\hline 18 & $\begin{array}{l}\text { Utilization of audio-visual equipment and } \\
\text { other mechanical aids }\end{array}$ & 42 & 200 & 009 & 011 & 012 & 022 & 009 \\
\hline 24 & $\begin{array}{l}\text { Managing classroom affairs in order to get } \\
\text { maximum benefit from supervising aides, } \\
\text { tutors, etc. }\end{array}$ & 43 & 194 & 005 & 016 & 016 & 021 & 005 \\
\hline 41 & Identifying the gifted and talented student & 44 & 194 & 006 & 013 & 017 & 024 & 003 \\
\hline 22 & $\begin{array}{l}\text { Deciding on appropriate pupil grouping } \\
\text { procedures for instruction }\end{array}$ & 45 & 189 & 007 & 014 & 018 & 020 & 004 \\
\hline 20 & $\begin{array}{l}\text { General presentation of information and } \\
\text { directions }\end{array}$ & 46 & 165 & 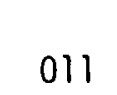 & 019 & 020 & 009 & 004 \\
\hline
\end{tabular}


Own Initiative; and item 38, Stimulating Growth of Pupil Attitudes and Values. Of the 7 items in this percentage group, 3 items--46, 45, and 44--came from Category IX, Integration of Faith, Learning, and Practice, 3 items--13, 39, and 38--came from category II, Developing Pupil Self and one item--14--was from category VIII, NonFactor Related Items.

The next 23 items were between the 79-70 percent level of the possible weighted score of 315 with weighted scores which ranged from 251 to 220. Item 42, Developing a Better Understanding of the Theory of Integrating Faith, Learning, and Practice and what Makes it Work, ranked first in this percentage group with 24 strongly agreed responses. There was a 31 point range between the 23 items in this percentage group. The items were clustered together with no more than a 4-point spread. Four sets of items which had the same weighted score were item 1, Diagnosing Basic Learning Difficulties, and item 26, Useful Methods of Classroom Discipline and When to Use Them (235). Item 31, Developing a Personal SelfEvaluation Method, and item 6, Involving Students in Self-Evaluation, had the same weighted score of 230 . Item 8 , Deciding What Teaching Technique $s$ Best for a Particular Intended Outcome, and item 19, Planning Teaching Activities with Other Teachers or Administrators, had the same weighted score of 225. Item 32, Developing a Broad Acceptance of Self, and item 16, Implementing and Supervising Individualized Instruction, had weighted scores of 220 . Four items which ranked seventeenth, eighteenth, nineteenth, and twentieth in this percentage group had equal numbers of 29 agreed responses. The 23 items in this percentage group came from all of the categories except Classroom Management, category VII. 
The third group which consisted of 15 items was in the 69 to 60 percent group and had weighted scores which ranged from 215 to $189, \bar{a}$ spread of 36 points. The items were clustered together with four sets of items having the same weighted score. Iter 28, Communicating and Interacting with Parents, item 33, Selecting and Specifying Performance Goals and Objectives, and iter 12, Evaluating Instruction/Instructional Design, ranked first, second, and third in this percentage group and had the same weighted score of 215. Others in the group that had the same weighted scores were items 34 and 5 with 209, items 21, 36, and 2 with 206, and items 24 and 41 with 194 . The 15 items came from six of the nine categories. The fourth group consisted of item 20, General Presentation of Information and Directions, which ranked 46 with a weighted score of 165. This was below the 60 percent level of the possible weighted score of 315 . It had the largest number of strongly disagreed with 11 responses. This item came from category VII, Classroom Management.

of the 46 items on the assessment, 45 were above the 60 percent level of the possible weighted score, 30 items were above the 70 percent level of the possible weighted score, and 7 items were above 80 percent of the possible weighted score of 315 .

The top 7 perceived inservice needs of the secondary teachers (9-12) of the Lake Union Conference were as follows:

1. Motivating Students to Learn on Their Own

2. Keeping Abreast of Developments in Your Own Subject Matter Area

3. Making Bible Instruction More Applicable to Everyday Life 
4. Transforming Faith into Action--By Vicarious Experience-Developing Christian Values and Attitutes

5. Constructing and Implenting a Christian Witnessing Program for Students and Teachers Together

6. Instilling in the Student the Will to Learn on His Own

7. Stimulating Growth of Pupil Attitudes and Values

Ranked Categories--Secondary Teachers

The description of the categories is presented in ranked order (table 9). Likewise, the description of the items within the categories is also presented in ranked order, according to the responses (table 10$)$.

Category IX, Integration of Faith, Learning, and Practice ranked first among the nine categories. Item 46, Making Bible Instruction More Applicable to Everyday Life, ranked first in the category with 29 strongly agreed responses. Item 45, Transforming Faith into Action--by Vicarious Experience--Developing Christian Values and Attitudes, ranked second. Items 44, Constructing and Implementing a Christian Witness Program for Students and Teachers Together, and item 42, Developing a Better Understanding of the Theory of Integrating Faith, Learning, and Practice and What Makes It Work, had 24 strongly agreed responses each. Category IX consisted of 5 questionnaire items--42, 43, 44, 45, and 46 . The mean score of 254 , shown in table 10, was 81 percent of the possible weighted score of 315 (63 teachers $\times 5)$.

Category II, Developing Pupil Self ranked second among the nine categories. Item 13, Motivating Students to Learn on Their Own, ranked first in the category with 30 strongly agree responses. 
TABLE 9

RANKED CATEGORIES OF ALL SECONOARY LAKE UNION CONFERENCE TEACHERS

\begin{tabular}{|c|c|c|c|c|c|c|c|c|}
\hline Rank & Categories & 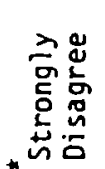 & 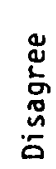 & 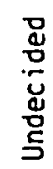 & 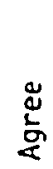 & 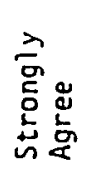 & 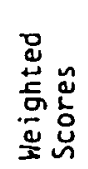 & 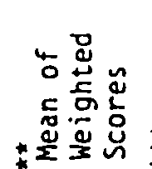 \\
\hline
\end{tabular}

1 IX Integration of Faith, Learning, and Practice 254 46 Making Bible instruction more applicable to everyday life

45 Transforming faith into action--by vicarious experience--developing Christian values and attitudes

44 Constructing and implementing a Christian witness program for students and teachers together

42 Developing a better understanding of the theory of integrating faith, learning

43 Knowing how to achieve faith, learning and practice from the curriculum through written objectives and evaluating results

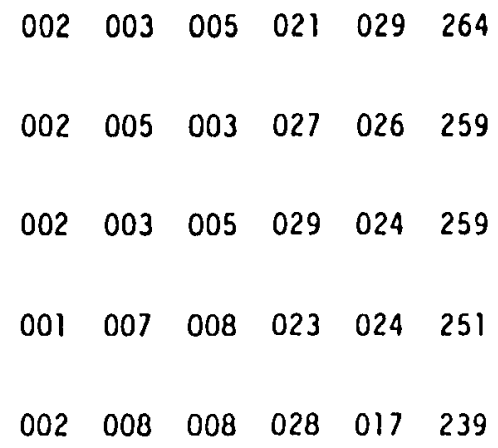

211 Developing Pupil Self

13 Motivating students to learn on their own

39 Instilling in the student the will to learn on his own initiative

38 Stimulating growth of pupil attitudes and values

35 Facilitatinj pupll self-concept and worth

37 Facilitating development of pupil responsibility

36 Facilitating pupil social interaction

$\begin{array}{llllll}000 & 003 & 003 & 027 & 030 & 273\end{array}$

$\begin{array}{llllll}002 & 005 & 004 & 026 & 027 & 258\end{array}$

$\begin{array}{llllll}002 & 005 & 003 & 033 & 020 & 253\end{array}$

$\begin{array}{llllll}002 & 008 & 004 & 028 & 021 & 240\end{array}$

$\begin{array}{llllll}003 & 008 & 008 & 023 & 021 & 240\end{array}$

$\begin{array}{llllll}003 & 015 & 014 & 024 & 007 & 206\end{array}$ 
TABLE 9--Continued

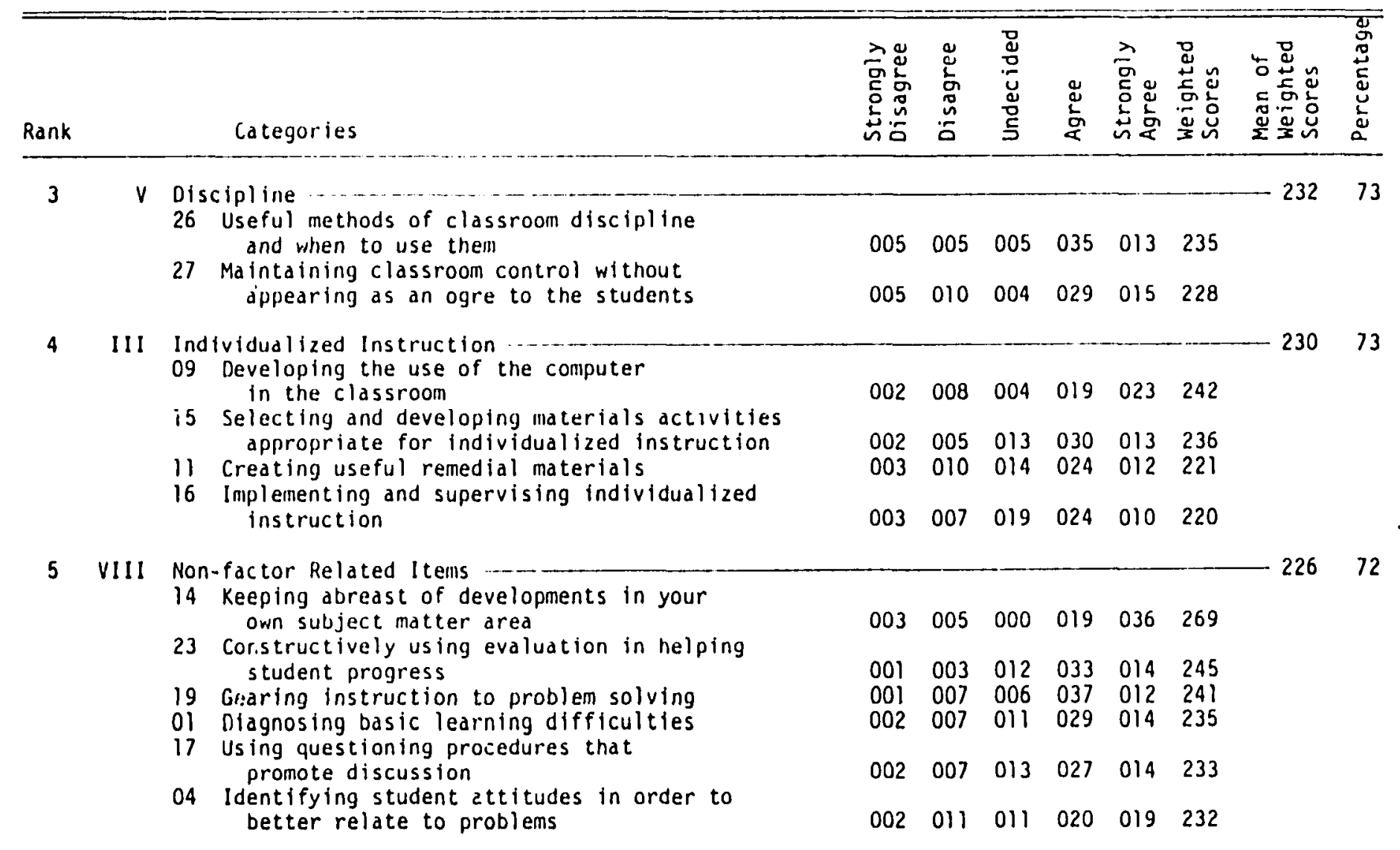


TABLE 9--Continued

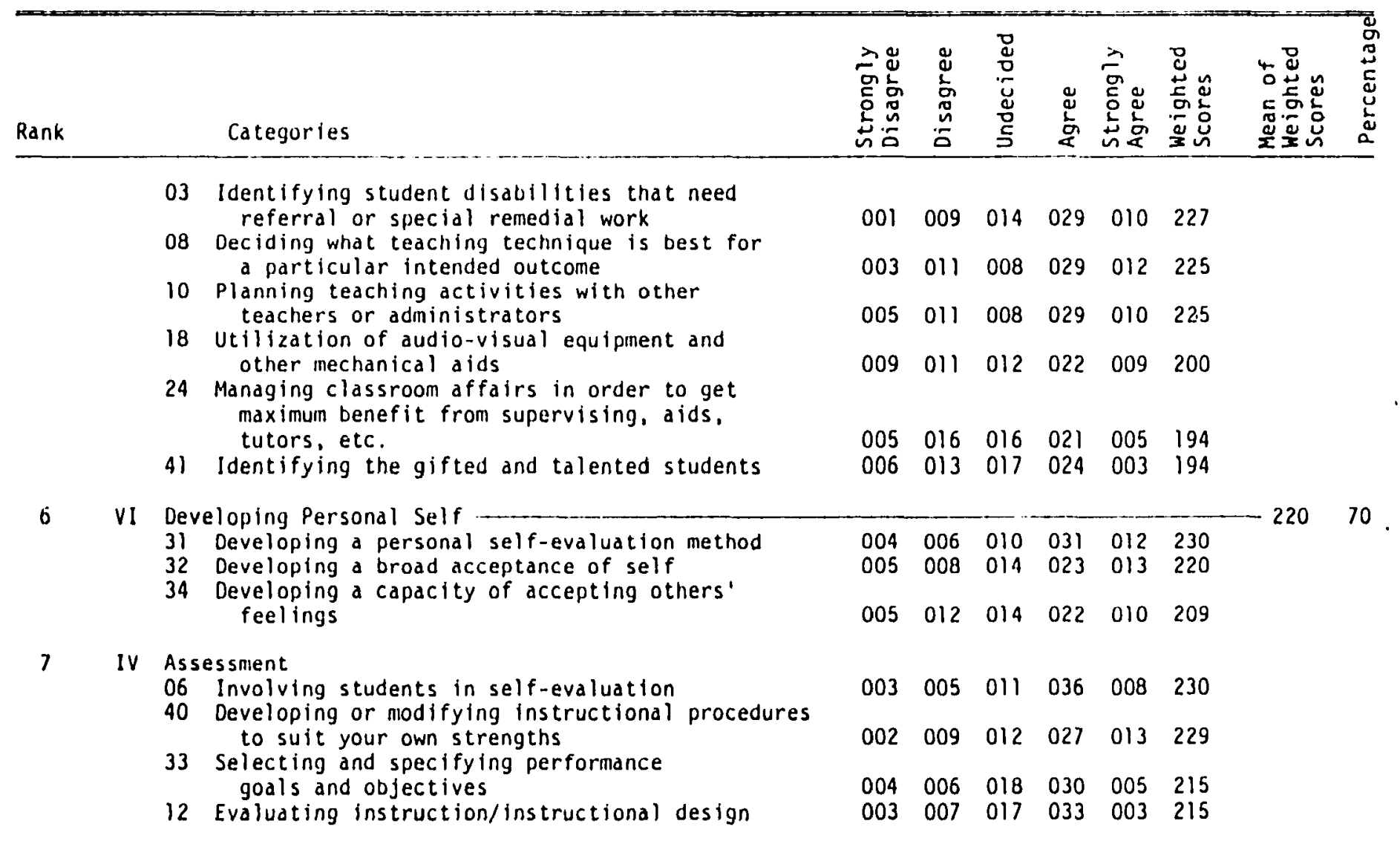


TABLE 9--Continued

\begin{tabular}{|c|c|c|c|c|c|c|c|c|c|c|c|}
\hline \multirow[t]{3}{*}{ Rank } & & & Categories & 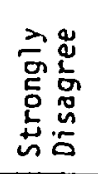 & 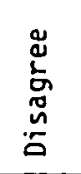 & 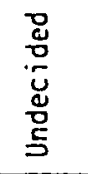 & 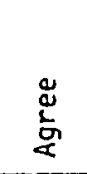 & 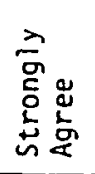 & 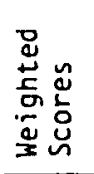 & 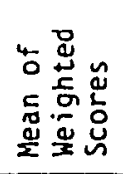 & 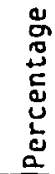 \\
\hline & & $\begin{array}{l}05 \\
02\end{array}$ & $\begin{array}{l}\text { Establishing appropriate performance standards } \\
\text { Constructing and using tests for }\end{array}$ & 002 & 015 & 013 & 027 & 006 & 209 & \multirow{7}{*}{-215} & \\
\hline & & & evaluating academic progress & 004 & 019 & 004 & 028 & 008 & 206 & & \\
\hline \multirow[t]{5}{*}{8} & I & Inte & erpersonal Comununication and Administration - & & & & & & & & 68 \\
\hline & & $\begin{array}{l}29 \\
28\end{array}$ & Counseling and conferring with students & 004 & 010 & 005 & 028 & 016 & 231 & & \\
\hline & & 30 & Involving others in the school programs & 005 & 006 & 020 & 027 & 005 & 210 & & \\
\hline & & & Knowing where to refer student problemis & & & & & & & & \\
\hline & & & Deyond what can be handled by the teacher & 007 & 011 & 013 & 023 & 009 & 205 & & \\
\hline \multirow[t]{5}{*}{9} & VII & Clas & ssroom Managenent - & & & & & & & 193 & 61 \\
\hline & & 07 & Teacher-pupil verbal interaction & 004 & 013 & 011 & 026 & 009 & 212 & & \\
\hline & & $\begin{array}{l}21 \\
22\end{array}$ & $\begin{array}{l}\text { Providing for reinforcement } \\
\text { Deciding on appropriate pupil grouping }\end{array}$ & 005 & 012 & 017 & 019 & 010 & 206 & & \\
\hline & & & procedures for instruction & 007 & 014 & 018 & 020 & 004 & 189 & & \\
\hline & & 20 & General presentation of information and directions & 011 & 019 & 020 & 009 & 004 & 165 & & \\
\hline
\end{tabular}

* Raw Scores

** Mean of the weighted score for the category

*** Percent of the possible weighted score 
TABLE 10

A SUMMARY OF RANKED CATEGORIES FOR ALL SECONDARY LAKE UNION CONFERENCE TEACHERS

\begin{tabular}{llcc}
\hline \multicolumn{1}{c}{ Categories } & $\begin{array}{c}\text { Ranking } \\
\text { Order }\end{array}$ & $\begin{array}{c}\text { Mean of } \\
\text { Weighted } \\
\text { Score* }\end{array}$ & $\begin{array}{c}\text { Percentage } \\
\text { of Possible } \\
\text { Weighted } \\
\text { Score }\end{array}$ \\
\hline IX Integration of Faith, Learning, and Practice & 1 & 254 & 81 \\
II Developing Pupil Self & 2 & 246 & 78 \\
V Discipline & 3 & 232 & 73 \\
III Individualized Instruction & 4 & 230 & 73 \\
VIII Non-factor Related Items & 5 & 226 & 72 \\
VI Developing Personal Self & 6 & 220 & 70 \\
IV Assessment & 7 & 217 & 69 \\
I Interpersonal Conmunication and Administration & 8 & 215 & 68 \\
VII Classroom Management & 9 & 193 & 61 \\
\hline
\end{tabular}
in the group]. 
Item 38, Stimulating Growth of Pupil Attitudes and Values, had the highest agreed responses (33) and ranked third in the category. Item 36, Facilitating Pupil Social Interaction, ranked last in the category with 15 disagreed responses. Category II consisted of 6 questionnaire items-- $13,35,36,37,38$, and 39 . The mean score of 246 , shown in table 10, was 78 percent of the possible weighted score of 315 .

Category $V$, Discipline, ranked third among the nine categories. Item 26, Useful Methods of Classroom Discipline and When to Use Them, ranked first in the category with 48 totalled agreed and strongly agreed responses. Item 27, Maintaining Classroom Control without Appearing as an Ogre to the Students, ranked last in the category. Category $V$ consisted of 2 questionnaire items- -26 and 27. The mean score of 232 , shown in table 10 , was 73 percent of the possible weighted score of 315.

Category III, Individualized Instruction, ranked third among the nine categories. Item 9, Developing the Use of the Computer in the Classroom, had 42 totalled agree and strongly agreed responses. Item 15, Selecting and Developing Materials Activities Appropriate for Individualized Instruction, ranked second in the category. Item 11, Creating Useful Remedial Materials, and item 16, Implementing and Supervising Individualized Instruction, ranked third and fourth in the category each with 24 agreed responses. Category III consisted of 4 questionnaire items--9, 11, 15, and 16 . The mean score of 230 , shown in table 10 , was 73 percent of the possible weighted score of 315 .

Category VIII, Non-factor Related Items, ranked fifth among 
the nine categories. Item 14, Keeping Abreast of Developments in Your Own Subject Matter Area, ranked first in the category with 36 strongly agreed responses. Item 19, Gearing Instruction to Problem Solving, ranked third with the highest number of agreed responses (37) in the category. Items in the category grouped together with the same number of agree, disagree and strongly disagree responses. Category VIII consisted of 12 questionnaire items--1, 3, 4, 8, 10 , $14,17,18,19,23,24$, and 41 . The mean score of 226 , shown in table 10, was 72 percent of the possible weighted score of 315 . Category VI, Developing Personal Self, ranked sixth among the nine categories. Item 31, Developing a Personal Self-Evaluation Method, ranked first in the category with 43 totalled agreed and strongly agreed responses. Item 32, Developing a Broad Acceptance of Self, and item 34, Developing a Capacity of Accepting Others' Feelings, ranked second and third with 14 undecided responses each. Category VI consisted of 3 questionnaire items--31, 32, and 34 . The mean score of 220 , shown in table 10 , was 70 percent of the possible weighted score of 315 .

Category IV, Assessment, ranked seventh among the nine categories. Item 6, Involving Students in Self-Evaluation, ranked first in the category with 36 agree responses. Item 40, Developing or Modifying Instructional Procedures to Suit Your Own Strengths, ranked second with 13 strongly agreed responses. Item 2, Constructing and Using Tests for Evaluating Academic Progress, ranked last with 19 disagreed responses. Category IV consisted of 6 questionnaire items--2, 5, $6,12,33$, and 40 . The mean score of 217, shown in table 10, was 69 percent of the possible weighted score of 315 . 
Category I, Interpersonal Communication and Administration, ranked eighth among the nine categories. Item 29, Counseling and Conferring with Students, ranked first in the category with the highest agreed (28) and strongly agreed (16) responses. Item 28, Communicating and Interacting with Parents, ranked second with the highest disagreed (15) responses. Category I consisted of 4 questionnaire items--25, 28, 29, and 30. The mean score of 215, shown in table 10 , was 68 percent of the possible weighted score of 315 .

Category VII, Classroom Management, ranked last among the nine categories. Item 7, Teacher-Pupil Verbal Interaction, ranked first in the category with 26 agreed responses. Item 21 , Providing for Reinforcement, ranked second with 10 strongly agree responses. Item 20, General Presentation of Information and Directions, ranked last in the category with a total of 30 disagree and strongly disagree responses. Category VII consisted of 4 questionnaire items--7, 20, 21, and 22. The mean score of 193, shown in table 10, was 61 percent of the possible weighted score of 315 .

Summary--K-12, El ementary and Secondary Teachers Perceived Needs

Research questions I (What are the perceived inservice needs of the $\mathrm{K}-12$ Lake Union Conference teachers?), 2 (What are the perceived inservice needs of the Lake Union Conference elementary teachers who teach grades $K-8$ ?), and 6 (What are the perceived inservice needs of the Lake Union Conference secondary teachers who teach grades 9-12?), as posed in chapter III, are addressed 
in the presentation of the responses of three groups; all K-12, elementary, and secondary teachers (table 11 and fig. 3 ).

TABLE 11

A COMPARISON OF RANKED CATEGORIES FOR ALL K-12, ELEMENTARY, AND SECONDARY TEACHERS

\begin{tabular}{lccccccccc}
\hline \hline & I & II & III & IV & V & VI & VII & VIII & IX \\
\hline A11 K-12 Teachers & 6 & 2 & 3 & 7 & 4 & 8 & 9 & 5 & 1 \\
All Secondary Teachers & 8 & 2 & 4 & 7 & 3 & 6 & 9 & 5 & 1 \\
All Elementary Teachers & 5 & 2 & 3 & 8 & 4 & 7 & 9 & 6 & 1 \\
\hline
\end{tabular}

Category IX, Integration of Faith, Learning, and Practice, was identified as the first perceived inservice need by all the K-12, el ementary and secondary teachers (fig. 3). Category II, Developing Pupil-Self, was ranked second by the three groups. Category III, Individualized Instruction, was ranked third by the K-12 and elementary teachers, whereas the secondary teachers ranked Category III, Individualized Instruction, fourth. Category V, Discipline, was ranked fourth by all the $k-12$ and elementary teachers and third by the secondary teachers. The remaining categories varied by one or two rankings except Category VII, Classroom Management, which was ranked last by all three groups.

\section{Ranked Categories of Elementary Teachers}

$$
\text { by Teaching Assignment }
$$

Ranked Categories of $\mathrm{K}-2$

Elementary Teachers

The description of the categories is presented in ranked order (table 12). Likewise, the description of the items within 


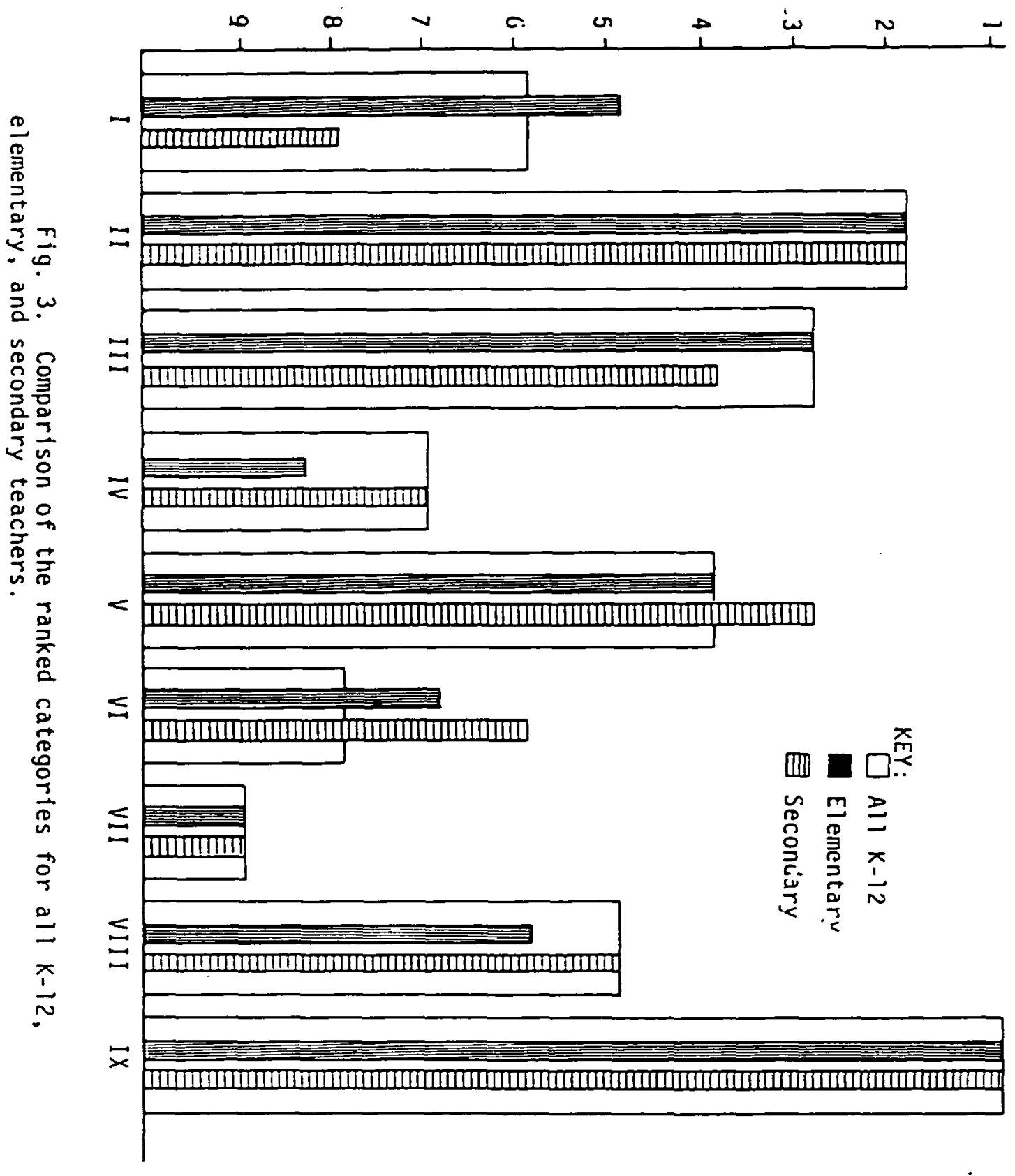


TABLE 12

A SUMMARY OF RANKED CATEGORIES OF K-2 ELEMENTARY LAKE UNION CONFERENCE TEACHERS

\begin{tabular}{lccc}
\hline \multicolumn{1}{c}{ Categories } & $\begin{array}{c}\text { Ranking } \\
\text { Order }\end{array}$ & $\begin{array}{c}\text { Mean of } \\
\text { Weighted } \\
\text { Score }\end{array}$ & $\begin{array}{c}\text { Percentage } \\
\text { of Pos ible } \\
\text { Weighted } \\
\text { Score }\end{array}$ \\
\hline IX Integration of Faith, Learning, and Practice & 1 & 111 & 79 \\
II Developing Pupil Self & 2 & 111 & 76 \\
III Individualized Instruction & 3 & 107 & 73 \\
V Discipline & 4 & 102 & 72 \\
I Interpersonal Communication and Administration & 5 & 101 & 72 \\
VIII Non-factor Related Items & 6 & 99 & 71 \\
IV Assessment & 7 & 95 & 68 \\
VI Developing Personal Self & 8 & 93 & 66 \\
VII Classroom Management & 9 & 87 & 62
\end{tabular}

*Maximum weighted score for this table was 140 [five times the number of teachers in the group]. 
the categories is also presented in ranked order, according to the responses.

Category IX, Integration of Faith, Learning, and Practice, ranked first among the nine categories. Item 46, Making Bible Instruction More Applicable to Everyday Life, ranked first in the category with 11 strongly agreed and 15 agreed responses. Item 42, Developing a Better Understanding of the Theory of Integrating Faith, Learning and Practice and What Makes It Work, ranked second in the category. Both item 45, Transforming Faith into Action--By Vicarious Experience--Developing Christian Values and Attitudes, and item 43, Knowing How to Achieve Faith, Learning and Practice from the Curriculum through Written Objectives and Evaluating Results, had 14 agreed responses. Item 45 ranked third while item 43 ranked last in the category. Items 46,42 , and 45 had no teacher who strongly disagreed with the item. Category IX consisted of 5 questionnaire items-- $42,43,44,45$, and 46 . The mean score of 111 , shown in table 12, was 79 percent of the possible weighted score of $140(28$ teachers $\times 5)$.

Category II, Developing Pupil Self, ranked second among the nine categories. Item 39, Instilling in the student the will to Learn on His Own Initiative, ranked first in the category with 12 agreed and 12 strongly agreed responses. Item 13, Motivating Students to Learn on Their Own, ranked second with 12 agreed and 11 strongly agreed responses. Both of the above items had weighted scores of 116. Item 35, Facilitating Pupil Self-Concept and Worth, ranked third with 18 agreed responses which was the highest number for the category. Two other items, 37, Facilitating Development 
of Pupil Responsibility, and 38, Stimulating Growth of Pupil

Attitudes and Values, also had 12 agreed responses as did the top

2 ranking items. Of the 6 items in the category no teacher strongly

disagreed with any of the items. Category II consisted of 6

questionnaire items-- $13,35,36,37,38$, and 39 . The mean score

of 111 , shown in table 12, was 76 percent of the possible weighted score of 140 .

Category III, Individualized Instruction, ranked third among the nine categories. Item 11, Creating Useful Remedial Materials, ranked first in the category with 12 agreed and 9 strongly agreed responses. Item 15, Selecting and Developing Materials Activities Appropriate for Individualized Instruction, ranked second with 20 agreed responses which was the highest number of responses in the category. Item 9, Developing the Use of the Computer in the Classroom, ranked last in the category with 7 undecided responses and 9 strongly agreed responses. The first and last ranking item had the same number of strongly agreed responses. Category III consisted of 5 questionnaire items--9, 11, 15, and 16. The mean score of 107, shown in table 12, was 73 percent of the possible weighted score of 140 .

Category V, Discipline, ranked fourth among the nine categories. Item 26, Useful Methods of Classroom Discipline and When to Use Them, ranked first with 12 agreed and 8 strongly agreed responses. Item 27, Maintaining Classroom Control without Appearing as an Ogre to the Students, ranked last with 6 undecided and a total of 6 disagree and strongly disagree responses. Category $V$ consisted of 2 questionnaire items--26 and 27 . The mean score of 102 , 
shown in table 12, was 72 percent of the possible weighted score of 140 .

Category I, Interpersonal Communication and Administration, ranked fifth among the nine categories. Item 25, Knowing where to Refer Student Problems beyond What Can Be Handled by the Teacher, ranked first in the category with a total of 20 agree and strongly agree responses. Item 30, Involving Others in the School Program, ranked second with the same totaled number of agreed and strongly agreed responses as item 25 which ranked first in the category. Only one teacher strongly disagreed with any of the items in this category. Category I consisted of 4 questionnaire items--25, 28, 29 , and 30 . The mean score of 101 , shown in table 12 , was 72 percent of the possible weighted score of 140 .

Category VIII, Non-factor Related Items, ranked sixth among the nine categories. Item 3, Identifying Student Disabilities that Need Referral or Special Remedial Work, ranked first in the category with 23 totaled agree and strongly agreed responses. Item 24, Managing Classroom Affairs in Order to Get Maximum Benefit from Supervising, Aids, Tutors, etc., ranked second in the category with the highest number of strongly agreed responses (9). Item 19, Gearing Instruction to Problem Solving, ranked fourth in the category with the highest number of agreed responses (18) in the category. Item 23, Constructively Using Evaluation in Helping Student Progress, item 41, Identifying the Gifted and Talented Students, and item 4, Identifying Student Attitudes in Order to Better Relate to Problems, all had 6 undecided responses which was the highest for the category. There were 6 of the 12 items with 
which no teacher strongly disagreed. Category VIII consisted of 12 questionnaire items $-1,3,4,8,10,14,17,18,19,23,24$, and 41 . The mean score of 99 , shown in table 12, was 71 percent of the possible weighted score of 140 .

Category IV, Assessment, ranked seventh among the nine categories. Item 40, Developing or Modifying Instructional Procedures to Suit Your Own Strengths, ranked first in the category with 7 strongly agreed and 7 disagreed responses. Item 12, Evaluating Instruction/Instructional Design, ranked second. Item 5, Establishing Appropriate Performance Standards, ranked third with the highest number of agreed responses (15). Item 2, Constructing and Using Tests for Evaluating Academic Progress, ranked fifth in the category and item 6, Involving Students in Self-Evaluation, ranked sixth in the category. Each had the same number of agreed responses (13) as did item 12 which ranked second. Category IV consisted of 5 questionnaire items--2, 5, 6, 12, 33, and 40 . The mean score of 95 , shown in table 12, was 68 percent of the possible weighted score of 140.

Category VI, Developing Personal Self, ranked eighth among the nine categories. Item 31, Developing a Personal Self-Evaluation Method, ranked first in the category with 4 strongly agreed responses and 11 agreed responses. Item 32, Developing a Broad Acceptance of Self, ranked second in the category with the highest number of undecided responses (9). Item 34, Developing a Capacity of Accepting Others' Feelings, ranked last in the category with the highest number of agreed responses (13). Category VI consisted of 3 
questionnaire items--31, 32, and 34. The mean score of 93 , shown in table 12, was 66 percent of the possible weighted score of 140 . Category VII, Classroom Management, ranked ninth among the nine categories. Item 22, Deciding on Appropriate Pupil Grouping Procedures for Instruction, ranked first in the category with 5 strongly agreed responses which was highest number for the strongly agreed responses. Item 21, Providing for Reinforcement, ranked second in the category with the highest number of agreed responses (12). Both item 22 and item 21 had 7 undecided responses while item 20, General Presentation of Information and Directions, and item 7, Teacher-Pupil Verbal Interaction, had the same number of disagreed responses (14). No teacher strongly disagreed with items 20 or 21 . Category VII consisted of 4 questionnaire items--7, 20, 21, and 22 . The mean score of 87 , shown in table 12, was 62 percent of the possible weighted score of 140 .

Ranked Categories of 3-5

Elementary Teachers

The description of the categories is presented in ranked order (table 13). Likewise, the description of the items within the categories is also presented in ranked order, according to the responses.

Category II, Developing Pupil Self, ranked first among the nine categories. Item 39, Instilling in the Student the will to Learn on His Own Initiative, ranked first in the category with 14 strongly agreed and 15 agreed responses. Item 38, Stimulating Growth of Pupi? Attitudes and Values, ranked second in the category with 13 strongly agreed responses. Item 36, Facilitating Pupil Social 
TABLE 13

A SUMMARY OF RANKED CATEGORIES OF 3-5 ELEMENTARY LAKE UNION CONFERENCE TEACHERS

\begin{tabular}{llll}
\multicolumn{1}{c}{ Categories } & $\begin{array}{c}\text { Mean of } \\
\text { Ranking } \\
\text { Order }\end{array}$ & $\begin{array}{c}\text { Weighted } \\
\text { Score }\end{array}$ & $\begin{array}{c}\text { Percentage } \\
\text { of Possible } \\
\text { Weighted } \\
\text { Score }\end{array}$ \\
\hline II Developing Pupil Self & 1 & 140 & 80 \\
III Individualized Instruction & 2 & 137 & 78 \\
IX Integration of Faith, Learning, and Practice & 3 & 131 & 75 \\
V Discipline & 4 & 130 & 75 \\
I Interpersonal Communication and Administration & 5 & 126 & 70 \\
VIII Non-factor Related Items & 6 & 122 & 67 \\
VI Developing Personal Self & 7 & 118 & 66 \\
IV Assessment & 8 & 116 & 61 \\
VII Classroom Management & 9 & 106 & 72 \\
\hline
\end{tabular}
in the group].

Maximum weighted score for this table was 175 [five times the number of teachers 
Interaction, ranked last in the category with the highest number of agreed responses (22). Of the 6 items in category III, item 37, Facilitating Development of Pupil Responsibility, item 35, Facilitating Pupil Self-Concept and Worth, and item 36, Facilitating Pupil Social Interaction, had no teacher strongly disagree with the concepts. The other 3 items, item 30, Instilling in the Student the Will to Learn on His Own Initiative, item 38, Stimulating Growth of Pupil Attitudes and Values, and item 13, Motivating Students to Learn on Their Own, had only one teacher strongly disagree with the item. Category II consisted of 6 questionnaire items--13, 35, 36, 37,38 , and 39 . The mean score of 140 , shown in table 13, was 80 percent of the possible weighted score of 175 (35 teachers $\times 5$ ). Category III, Individualized Instruction, ranked second among the nine categories. Item 9, Developing the Use of the Computer in the Classroom, ranked first in the category with 17 strongly agreed and 6 agreed responses. The item also had the highest number of undecided responses (9). Item 11, Creating Useful Remedial Materials, ranked second in the category with 17 agreed and 10 strongly agreed responses. Likewise item 15, Selecting and Developing Materials Activities Appropriate for Individualized Instruction, also had 17 agreed responses. Item 16, Imolementing and Supervising Individualized Instruction, ranked last in the category with the highest number of agreed responses (19). Category III consisted of 4 questionnaire items--9, 11, 15, and 16 . The mean score of 137 , shown in table 13, was 78 percent of the possible weighted score of 175.

Category IX, Integration of Faith, Learning, and Practice, 
ranked third among the nine cațegories. Item 46, Making Bible Instruction More Applicable to Everyday Life, ranked first in the category with 15 strongly agreed and 14 agreed responses. Item 45, Transforming Faith into Action--By Vicarious Experience--Developing Christian Values and Attitudes, ranked second in the category with the highest number of agreed responses (19). No teacher strongly disagreed with this item. Category IX consisted of 5 questionnaire items- $-42,43,44,45$, and 46 . The mean score of 131 , shown in table 13, was 75 percent of the possible weighted score of 175 . Category $V$, Discipline, ranked fourth among the nine categories. Item 27, Maintaining Classroom Control without Appearing as an Ogre to the Students, ranked first in the category with 12 strongly agreed and 12 agreed responses. Item 26, Useful Methods of Classroom Discipline and When to Use Them, ranked second in the category with 13 agreed responses which is the highest of the category. Both items mentioned above had 4 undecided responses and no teacher who strongly disagreed with the items. Category $V$ consisted of 2 questionnaire items--26 and 27. The mean score of 130 , shown in table 13, was 75 percent of the possible weighted score of 175 .

Category I, Interpersonal Communication and Administration, ranked fifth among the nine categories. Item 30, Involving Others in the School Program, ranked first in the category with 3 strongly agreed and 21 agreed responses. Item 29, Counseling and Conferring with Students, ranked second in the category. Item 28 ranked third in the category with 8 strongly agreed responses which was the highest number of strongly agreed responses for the category. 
Each of the above 3 items had one teacher who strongly disagreed. Category I consisted of 4 questionnaire items--25, 28, 29, and 30 . The mean score of 126, shown in table 13, was 72 percent of the possible weighted score of 175.

Category VIII, Non-Factor Related Items, ranked sixth among the nine categories. Item 1, Diagnosing Basic Learning Difficulties, ranked first in the category with 12 strongly agreed and 15 agreed responses. Item 3, Identifying Student Disabilities That Need Referral or Special Remedial Work, ranked second in the category. Four of the 12 items, item 4, Identifying Student Attitudes in Order to Better Relate to Problems, item 23, Constructively Using Evaluation in Helping Student Progress, item 19, Gearing Instruction to Problem Solving, and item 41, Identifying the Gifted and Talented Students, all had 19 agreed responses which was the highest number for the category. They ranked fourth, sixth, seventh, and eighth, respectively. Item 3, Identifying Student Disabilities That Need Referral or Special Remedial Work, item 24, Managing Classroom Affairs in Order to Get Maximum Benefit from Supervising, Aids, Tutors, etc., item 4, Identifying Student Attitudes in Order to Better Relate to Problems, item 14, Keeping Abreast of Developments in Your Own Subject Matter Area, item 23, Constructively Using Evaluation in Helping Student Progress, and item 19, Gearing Instruction to Problem Solving, had no teacher disagree with the items. Category VIII consisted of 12 questionnaire items-- 1, 3, 4, 8, 10, $14,17,18,19,23,24$, and 41 . The mean score of 122, shown in table 13, was 70 percent of the possible weighted score of 175 . Category VI, Developing Pupil Self, ranked seventh among 
the nine categories. Item 31, Developing a Personal Self-Evaluation Method, ranked first in the category with 4 strongly agreed and 18 agreed responses. Item 34, Developing a Capacity of Accepting Others' Feelings, ranked second in the category with 8 strongly agree responses which was the highest for the strongly agreed responses. Soth of the above items had 9 disagreed responses. Item 32, Developing a Broad Acceptance of Self, ranked last in the category. Category VI consisted of 3 questionnaire items-31,32 , and 34 . The mean score of 118 , shown in table 13, was 67 percent of the possible weighted score of 175 .

Category IV, Assessment, ranked eighth among the nine categories. Item 40, Developing or Modifying Instructional Procedures to Suit Your Own Strengths, ranked first in the category with 4 strongly agreed and 18 agreed responses. Item 12, Evaluating Instruction/Instructional Design, ranked second in the category. of the two top items, no teacher strongly disagreed. Both item 12, Evaluating Instruction/Instructional Design, and item 13, Motivating Students to Learn on Their Own, had 13 agreed and 4 strongly agree responses. Item 6 , Involving Students in Self-Evaluation, ranked last in the category with 18 agreed responses which was the same number of agreed responses on item 40 which ranked first. Category IV consisted of 6 questionnaire items--2, 5, 6, 12,33, and 40 . The mean score of 116, shown in table 13, was 66 percent of the possible weighted score of 175 .

Category VII, Classroom Management, ranked ninth among the nine categories. Item 22, Deciding on Appropriate Pupil-Grouping Procedures for Instruction, ranked first in the category with 4 
strongly agreed and 12 agreed responses. Item 21, Providing for Reinforcement, ranked second in the category with 17 agreed responses which was the highest for the category. Neither item 21 nor item 7, Teacher-Pupil Verbal Interaction, which ranked third in the category, had any teachers who strongly agreed with the item. Category VII consisted of 3 questionnaire items--31, 32, and 34 . The mean score of 106, shown in table 13, was 61 percent of the possible weighted score of 175 .

Ranked Categories of $6-8$

Elementary Teachers

The description of the categories is presented in ranked order (table 14). Likewise, the description of the items within the categories is also presented in ranked order, according to the responses.

Category IX, Integration of Faith, Learning, and Practice, ranked first among the nine categories. Item 46, Making Bible Instruction More Applicable to Everyday Life, ranked first in the category with 19 strongly agreed, 8 agreed, and 0 strongly disagree responses. Item 44 , Constructing and Implementing a Christian Witness Program for Students and Teachers Together, ranked second in the category with 15 strongly agree, 12 agree, and 0 strongly disagreed responses. Both item 45, Transforming Faith into Action-By Vicarious Experience--Developing Christian Values and Attitudes, and item 42, Developing a Better Understanding of the Theory of Integrating Faith, Learning, and Practice and What Makes It Work, ranked third and fourth, respectively, had 13 strongly agreed and 5 undecided responses. Item 43, Knowing How to Achieve Faith, 
TABLE 14

A SUMMARY OF RANKED CATEGORIES OF 6-8 ELEMENTARY LAKE UNION CONFERENCE TEACHERS

\begin{tabular}{llcc}
\hline \multicolumn{1}{c}{ Categories } & $\begin{array}{c}\text { Ranking } \\
\text { Order }\end{array}$ & $\begin{array}{r}\text { Mean of } \\
\text { Weighted } \\
\text { Score* }\end{array}$ & $\begin{array}{c}\text { Percentage } \\
\text { of Possible } \\
\text { Weighted } \\
\text { Score }\end{array}$ \\
\hline IX Integration of Faith, Learning, and Practice & 1 & 131 & 79 \\
III Individualized Instruction & 2 & 128 & 77 \\
II Developing Pupil Self & 3 & 127 & 77 \\
V Discipline & 4 & 119 & 72 \\
VIII Non-factor Related Item & 5 & 117 & 71 \\
VI Developing Personal Self & 6 & 116 & 71 \\
I Interpersonal Communication and Administration & 7 & 114 & 69 \\
IV Assessment & 8 & 112 & 68 \\
VII Classroom Management & 9 & 105 & 64
\end{tabular}
in the group]. 
Learning, and Practice from the Curriculum through Written Objectives and Evaluating Results, ranked last in the category. Category IX consisted of 5 questionnaire items- $-42,43,44,45$, and 46 . The mean score of 131 , shown in table 14, was 79 percent of the possible weighted score of 165 (37 teachers $\times 5$ ).

Category III, Individualized instruction, ranked second among the nine categories. Item 9, Developing the lise of the Computer in the Classroom, ranked first in the category with 14 strongly agreed and 13 agreed responses. Item 11, Creating Useful Remedial Materials, ranked second in the category with 14 agreed and no strongly disagreed responses. Item 16, Implementing and Supervising Individualized Instruction, had 20 agreed responses which was the highest number for the category. Both item 16 and item 15, Selecting and Developing Materials Activities Appropriate for Individualized Instruction, had 6 undecided responses. Category III consisted of 4 questionnaire items--9, 11, 15, and 16 . The mean score of 128, shown in table 14, was 77 percent of the possible weighted score of 165 .

Category II, Developing Pupil Self, ranked third among the nine categories. Item 39, Instilling in the Student the will to Learn on His Own Initiative, ranked first in the category with 16 strongly agreed and 12 agreed responses. Item 13, Motivating Students to Learn on Their Own, ranked second in the category with 16 strongly agreed responses which was the highest number for the strongly agreed responses. Both of the above items had 4 disagreed responses. Likewise, item 35, Facilitating Pupil SelfConcept and Worth, item 37, Facilitating Development of Pupil 
Responsibility, item 38, Stimulating Growth of Pupil Attitudes and Values, had the same number of disagreed responses (4), and items 13, 35, 37, and 38 all had 3 undecided responses. Item 37, Facilitating Development of Pupil Responsibility, and item 38, Stimulating Growth of Pupil Attitudes and Values, had the same number of responses in each cell of the Likert-type scale. Category II consisted of 6 questionnaire items--13,35,36,37,38, and 39. The mean score of 127 , shown in table 14, was 77 percent of the possible weighted score of 165 .

Category V, Discipline, ranked fourth among the nine categories. Item 26, Useful Methods of Classroom Discipline and When to Use Them, ranked first in the category with 10 strongly agreed and 13 agreed responses. Item 27, Maintaining Classroom Control without Appearing as an Ogre to the Students, ranked second in the category. Category $V$ consisted of 2 questionnaire items--26 and 27 . The mean score of 119 , shown in table 14, was 72 percent of the possible weighted score of 165 .

Category VIII, Non-Factor Related Items, ranked fifth among the nine categories. Item 1, Diagnosing Basic Learning Difficulties, ranked first in the category with 8 strongly agreed and 18 agreed responses. Item 14, Keeping Abreast of Developments in Your Own Subject Matter Area, ranked second in the category with 11 strongly agreed and 11 agreed responses. Neither of the above items had any teacher who strongly disagreed with them. Likewise as number one, item 23, Constructively Using Evaluation in Helping Student Progress, item 3, Identifying Student Disabilities that Need Referral or Special Remedial Work, and item 19, Gearing Instruction 
to Problem Solving, had the same number of strongly agreed responses (8) while items 3,19 , and 10, Planning Teaching Activities with Other Teachers or Administrators and item 8, Deciding What Teaching Technique Is Best for a Particular Intended Outcome, all had 8 disagreed responses. Category VIII consisted of 12 questionnaire items-- $1,3,4,8,10,14,17,18,19,23,24$, and 41 . The mean score of 117 , shown in table 14, was 71 percent of the possible weighted score of 165.

Category VI, Developing Personal Self, ranked sixth among the nine categories. Item 31, Developing a Personal Self-Evaluation Method, ranked first in the category with 7 strongly agreed and 14 agreed responses. Item 32, Developing a Broad Acceptance of Self, ranked second in the category with the highest number of strongly agreed response (9). The two items mentioned above and item 34, Developing a Capacity of Accepting Others' Feelings, all had 7 undecided responses. Likewise, both items 31 and 32 each had 2 strongly disagree responses, as did item 32 and item 34 which had 5 disagreed responses each. Category VI consisted of 3 questionnaire items--31, 32, and 34 . The mean score of 116 , shown in table 14, was 71 percent of the possible weighted score of 164 .

Category I, Interpersonal Communication and Administration, ranked seventh among the nine categories. Item 29, Counseling and Conferring with Students, ranked first in the category with 9 strongly agreed and 13 agreed responses. Item 30, Involving 0thers in the School Program, ranked second in the category with 17 agreed responses which was the highest for the category. Both of the above items had one teacher who strongly disagreed with each item. 
Item 25, Knowing Where to Refer Student Problems beyond What Can Be Handled by the Teacher, ranked last in the category with 10 agree and 10 disagree responses. Category I consisted of 4 questionnaire items--25, 28, 29, and 30 . The mean score of 114 , shown in table 14, was 60 percent of the possible weighted score of 165 .

Category IV, Assessment, ranked eighth among the nine categories. Item 6, Involving Students in Self-Evaluation, ranked first in the category with 7 strongly agreed and 15 agreed responses. Item 14, Keeping Abreast of Developments in Your Own Subject Matter Area, ranked second in the category. Both of the above $i$ tems had one teacher who strongly disagreed with each item. Item 2, Constructing and Using Tests for Evaluating Academic Progress, ranked last in the category with 18 agreed responses which was the highest for the category but also received a total of 10 disagree and strongly disagree responses. Category IV consisted of 6 questionnaire items--2, 5, 6, 12, 33, and 40 . The mean score of 112, shown in table 14, was 68 percent of the possible weighted score of 165 .

Category VII, Classroom Management, ranked ninth among the nine categories. Item 21, Providing for Reinforcement, ranked first in the category with 7 strongly agreed and 13 agreed responses. Item 7 , Teacher-Pupil Verbal Interaction, ranked second in the category with 14 agreed and 4 strongly agreed responses. The above item and item 22, Deciding on Appropriate Pupil Grouping Procedures for Instruction, which ranked third, all had 5 undecided responses with an equal number of strongly disagreed and disagreed 
as agreed and strongly agreed responses (14). Item 20, General Presentation of Information and Directions, also had a total of 14 disagreed and strongly disagreed responses. Category VII consisted of four questionnaire items--7, 20, 21, and 22. The mean score of 105, shown in table 14, was 64 percent of the possible weighted score of 165 .

Summary--El ementary Teachers by Teaching Assignment

Research questions 3 (What are the perceived inservice needs of Lake Union Conference elementary teachers who teach grades K-2?), 4 (What are the perceived inservice needs of Lake Union Conference elementary teachers who teach grades 3-5?), and 5 (What are the perceived inservice needs of Lake Union Conference elementary teachers who teach grades $6-8$ ?), as posed in chapter III are addressed in the presentation of the responses of three groups of elementary teachers who have taught grades $\mathrm{K}-2$, elementary teachers who have taught grades 3-5, and el ementary teachers who have taught grades 6-8. In addition, the above responses were compared to all the elementary teachers of the Lake Union Conference (fig. 4 and table 15).

Category IX, Integration of Faith, Learning, and Practice was identified as the first perceived inservice need by the $k-2$ and 6-8 teachers, but it was perceived as the third inservice need by the 3-5 teachers whereas the category was ranked first by all the elementary teachers.

Category II, Developing Pupil Self, was ranked second by the $\mathrm{K}-2$, first by the $3-5$, and third by the $6-8$ teachers, whereas 


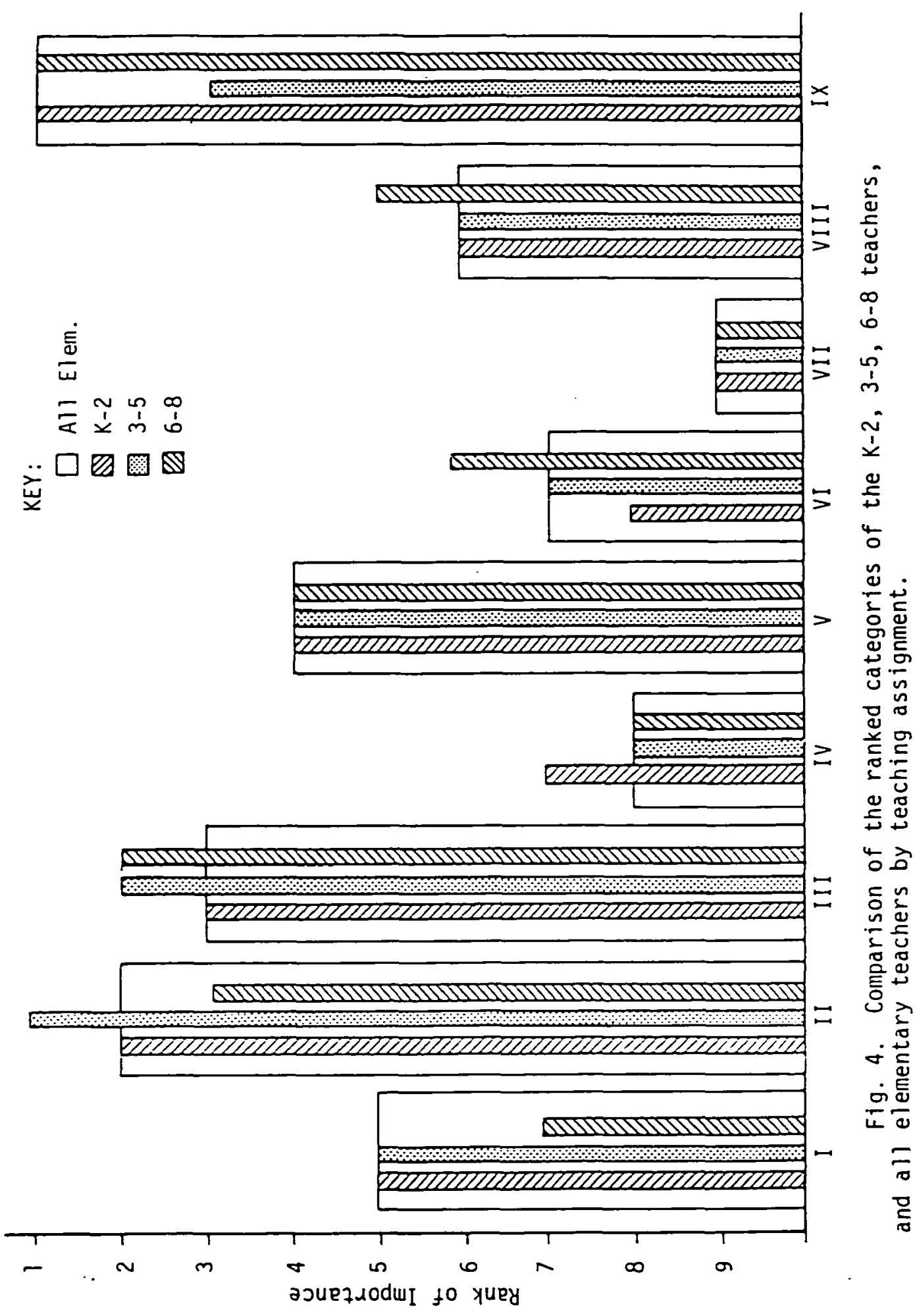


the category was ranked second by all the elementary teachers.

Category III, Individualized Instruction, was ranked third by the $\mathrm{K}-2$ teachers, but the $3-5$ and $6-8$ teachers ranked the category second whereas the category was ranked third by all the el ementary teachers.

Category $V$, Discipline, was ranked fourth by all groups.

The remaining categories varied by over two ranking except for category VII, Classroom Management which was ranked last by all three groups.

\section{Elementary Teachers by Years}

$$
\text { of Experience }
$$

Ranked Categories of Elementary Teachers with $0-5$ Years of Experience

The description of the categories is presented in ranked order (table 16). Likewise, the description of the items within the categories is also presented in ranked order, according to the responses (table 15 ).

TABLE 15

A COMPARISON OF RANKED CATEGORIES OF $K-2,3-5,6-8$ TEACHERS AND ALL ELEMENTARY TEACHERS BY TEACHING ASSIGNMENT

\begin{tabular}{lccccccccc}
\hline \hline $\begin{array}{l}\text { Teaching } \\
\text { Assignment }\end{array}$ & I & II & III & IV & V & VI & VII & VIII & IX \\
\hline AII Elementary & 5 & 2 & 3 & 8 & 4 & 7 & 9 & 6 & 1 \\
K-2 & 5 & 2 & 3 & 7 & 4 & 8 & 9 & 6 & 1 \\
$3-5$ & 5 & 1 & 2 & 8 & 4 & 7 & 9 & 6 & 3 \\
$6-8$ & 7 & 3 & 2 & 8 & 4 & 6 & 9 & 5 & 1 \\
\hline
\end{tabular}


A SUMMARY OF THE RANKED CATEGORIES OF ELEMENTARY TEACHERS WITH 0-5 YEARS OF EXPERIENCE

\begin{tabular}{lllc} 
Categories & $\begin{array}{c}\text { Mean of } \\
\text { Ranking } \\
\text { Order }\end{array}$ & $\begin{array}{c}\text { Percentage } \\
\text { Weighted } \\
\text { Score }\end{array}$ & $\begin{array}{c}\text { Weighted } \\
\text { Wossible } \\
\text { Score }\end{array}$ \\
\hline II Developing Pupil Self & 1 & 138 & 81 \\
IX Integration of Faith, Learning, and Practice & 2 & 135 & 79 \\
V Discipline & 3 & 134 & 79 \\
III Individualized Instruction & 4 & 130 & 73 \\
I Interpersonal Communication and Administration & 5 & 124 & 70 \\
VIII Non-factor Related Items & 6 & 119 & 69 \\
IV Assessment & 7 & 118 & 67 \\
VI Developing Personal Self & 3 & 113 & 65 \\
VII Classroom Management & 9 & 110 & 79
\end{tabular}

*Maximum weighted score for this table was 170 [five times the number of teachers in the group]. 
Category II, Developing Pupil Self, ranked first among the nine categories. Item 39; Instilling in the Student the Will to Learn on His Own Initiative, ranked first in the category with 16 strongly agreed and 14 agreed responses. Item 13, Motivating Students to Learn on Their Own, ranked second in the category. Item 36, Facilitating Pupil Social Interaction, ranked last in the category with 22 agreed responses which was the highest for the category. No teacher strongly disagreed with any one of the 6 items in the category. Category II consisted of 6 questionnaire items-$13,35,36,37,38$, and 39 . The mean score of 138 , shown in table 16, was 81 percent of the possible weighted score of 170 (34 teachers $\times 5)$.

Category IX, Integration of Faith, Learning, and Practice, ranked second among the nine categories. Item 46, Making Bible Instruction More Applicable to Everyday Life, ranked first in the category with 18 strongly agreed and 12 agreed responses. Item 44 , Constructing and Implementing a Christian Witness Program for Students and Teachers Together, ranked second in the category with 15 agreed responses which was the highest number of agreed responses. Item 45, Transforming Faith into Action--8y Vicarious Experience-Developing Christian Values and Attitudes, item 42, Developing a Better Understanding of the Theory of Integrating Faith, Learning and Practice and What Makes it Work, and item 43, Knowing How to Achieve Faith, Learning, and Practice from the Curriculum through Written Objectives and Evaluating Results, all had the same number of agreed responses (14). Only item 45 and item 43 had one teacher who strongly disagreed with each item. Category IX consisted 
of 5 questionnaire items-- $42,43,44,45$, and 46 . The mean score of 135, shown in table 16, was 79 percent of the possible weighted score of 170 .

Category $V$, Discipline, ranked third among the nine categories. Item 26, Useful Methods of Classroom Discipline and When to Use Them, ranked first in the category with 13 strongly agreed and 14 agreed responses. Item 27, Maintaining Classroom Control without Appearing as an Ogre to the Students, ranked second in the category with 16 agreed responses which was the highest in the category. Neither of the above icems had a teacher who strongly disagreed with the items. Category $V$ consisted of 2 questionnaire items--26 and 27 . The mean score of 134, shown in cable 16, was 79 percent of the possible weighted score of 170 .

Category III, Individualized Instruction, ranked fourth among the nine categories. Item 11, Creating Useful Remedial Materials, ranked first in the category with 13 strongly agreed and 13 agreed responses. Item 2, Developing the Use of the Computer in the Classroom, ranked second in the category with 16 strongly agree responses. Item 16, Implementing and Supervising Individualized Instruction, ranked last in the category with 17 agreed responses which was the highest responses for the category. No teacher strongly disagreed with any of the 4 items in this category. Category III consisted of 4 questionnaire items--9, 11,15 , and 16 . The mean score of 130 , shown in table 16, was 77 percent of the possible weighted score of 170 .

Category I, Interpersonal Communication and Administration, ranked fifth among the nine categories. Item 30, Involving Others 
in the School Program, ranked first in the category with 6 strongly agreed and 17 agreed responses. Item 25, Knowing Where to Refer Student Problems beyond What Can Be Handled by the Teacher, ranked second in the category with 9 strongly agreed responses. Of the above 2 items, no teacher strongly disagreed with either item. Item 28, Communicating and Interacting with Parents, ranked third in the category with the highest number of agreed responses (18) and 2 strongly disagreed responses. Category I consisted of 4 questionnaire items- $-25,28,29$, and 30 . The mean score of 124 , shown in tabie 16, was 73 percent of the possible weighted score of 170 .

Category VIII, Non-Factor Related Items, ranked sixth among the nine categories. Item 1, Diagnosing Basic Learning Difficulties, ranked first in the category with 10 strongly agreed and 21 agreed responses. Item 24, Managing Classroom Affairs in Order to Get Maximum Benefit from Supervising, Aids, Tutors, etc., ranked second and third in the category with 8 strongly agreed and 14 agreed responses each. Likewise, item 17, Using Questioning Procedures that Promote Discussion, item 19, Gearing Instruction to Problem Solving, item 41, Identifying the Gifted and Talented Students, and item 8, Deciding what Teaching Technique Is Best for a Particular Intended Outcome, all had 18 agreed responses. No teacher strongly disagreed with the following 7 (of 12) items: item 1, Diagnosing Basic Learning Difficulties, item 24, Managing Classroom Affairs in Order to Get Maximum Benefit from Supervising, Aids, Tutors, etc., item 3, Identifying Student Disabilities That Need Referral or Special Remedial Work, item 19, Gearing Instruction 
to Problem Solving, item 23, Constructively Using Evaluation in Helping Student Progress, item 14, Keeping Abreast of Developments in Your Own Subject Matter Area, and item 4, Identifying Student Attitudes in Order to Better Relate to Problems. Category VIII consisted of 12 questionnaire items-- $1,3,4,8,10,14,17,18$, $19,23,24$, and 41 . The mean score of 119 , shown in table 16 , was 70 percent of the possible weighted score of 170 .

Category IV, Assessment, ranked seventh among the nine categories. Item 2, Constructing and Using Tests for Evaluating Academic Progress, ranked first in the category with 4 strongly agreed, 19 agreed, and 0 strongly agreed responses. Item 33, Selecting and Specifying Performance Goals and Objectives, ranked second in the category with 6 strongly agreed responses which was the highest number for those responses. Both items 40, Developing or Modifying Instructional Procedures to Suit Your Own Strengths, and item 12, Evaluating Instruction/Instructional Design, had same number of strongly agreed responses (5), while item 33, Selecting and Specifying Performance Goals and Objectives, and item 40, Developing or Modifying Instructional Procedures to Suit Your Own Strengths, both had 8 undecided responses. Likewise, item 40, Developing or Modifying instructional Procedures to Suit Your Own Strengths, item 12, Evaluating Instruction/Instructional Design, item 6, Involving Students in Self-Evaluation, item 5, Establishing Appropriate Performance Standards, all had 7 disagreed responses. Category IV consisted of 6 questionnaire items--2, 5, 6, 12, 33, and 40 . The mean score of 118 , shown in table 16, was 69 percent of the possible weighted score of 170 . 
Category VI, Developing Personal Self, ranked eighth among the nine categories. Item 31, Developing a Personal SelfEvaluation Method, ranked first in the category with 7 strongly agreed and 14 agreed responses. Item 32, Developing a Broad Acceptance of Self, ranked second in the category. The above item had the same number of disagreed responses (10) as did item 34 , Developing a Capacity of Accepting Others' Feelings. Category VI consisted of 3 questionnaire items--31, 32, and 34 . The mean score of 113, shown in table 16, was 67 percent of the possible weighted score of 170 .

Category VII, Classroom Management, ranked ninth among the nine categories. Item 21, Providing for Reinforcement, ranked first in the category with 5 strongly agreed and 16 agreed responses. Item 22, Deciding on Appropriate Pupil Grouping Procedures for Instruction, ranked second in the category with 8 strongly agreed responses. Both items 20, General Presentation of Information and Directions, and item 7, Teacher-Pupil Verbal Interaction, which ranked last in the category, had 13 agreed responses. Item 7 , Teacher-Pupil Verbal Interaction, also had a total of 14 agreed and strongly agreed and 14 disagree and strongly disagree responses. Category VII consisted of 4 questionnaire items--7, 20, 21, and 22. The mean score of 110, shown in table 16, was 65 percent of the possible weighted score of 170 .

Ranked Categories of Elementary Teachers with $6-10$ Years of Experience

The description of the categories is presented in ranked order (table 17). Likewise, the description of the items within 
TABLE 17

A SUMMARY OF RANKED CATEGORIES OF LAKE UNION CONFERENCE ELEMENTARY TEACHERS WITH 6-10 YEARS OF EXPERIENCE

\begin{tabular}{llll}
\hline Categories & $\begin{array}{c}\text { Mean of } \\
\text { Ranking } \\
\text { Order }\end{array}$ & $\begin{array}{c}\text { Percentage } \\
\text { Weighted } \\
\text { Score }\end{array}$ & $\begin{array}{c}\text { of Possible } \\
\text { Whted } \\
\text { Score }\end{array}$ \\
\hline IX Integration of Faith, Learning, and Practice & 1 & 162 & 81 \\
II Developing of Pupil Self & 2 & 152 & 76 \\
III Individualized Instruction & 3 & 146 & 73 \\
I Interpersonal Communication and Administration & 4 & 145 & 73 \\
VIII Non-factor Related Item & 5 & 141 & 70 \\
V Discipline & 6 & 141 & 68 \\
VI Developing Personal Self & 7 & 135 & 66 \\
IV Assessment & 8 & 133 & 60 \\
\hline
\end{tabular}

*Maximum weighted score for this table was 200 [five times the number of teachers in the group]. 
the categories is also presented in ranked order, according to the responses.

Category IX, Integration of Faith, Learning, and Practice, ranked first among the nine categories. Item 46 , Making Bible Instruction More Applicable to Everyday Life, ranked first in the category with 21 strongly agreed and 14 agreed responses. Item 45, Transforming Faith into Action--By Vicarious Experience-Developing Christian Values and Attitudes, ranked second in the category with 19 agreed responses, which was the highest for the category. Of the above two items, no teacher strongly disagree with either item. Both item 44, Constructing and Implementing a Christian Witness Program for Students and Teachers Together, and item 42, Developing a Better Understanding of the Theory of Integrating Faith, Learning, and Practice and What Makes It Hork, had 16 agreed and one strongly agreed responses. Category IX consisted of 5 questionnaire items- $-42,43,44,45$, and 46 . The mean score of 162, shown in table 17, was 81 percent of the possible weighted score of 200 ( 40 teachers $\times 5$ ).

Category II, Developing Pupil Self, ranked second among the nine categories. Item 39, Instilling in the Student the Will to Learn on His Own Initiative, ranked first in the category with 13 strongly agreed and 21 agreed responses. Item 38, Stimulating Growth of Pupil Attitudes and Values, ranked second in the category with 22 agreed responses, which was the highest number of responses for the category. Of the two items mentioned above, no teacher strongly disagreed with the items. Item 35, Facilitating Pupil Self-Concept and Worth, which ranked fourth in the category, also 
had 22 agreed and 0 strongly disagreed responses. Item 36 , Facilitating Pupil Social Interaction, ranked last with the highest number of undecided responses (10). Category II consisted of 6 questionnaire items- $-13,35,36,37,38$, and 39 . The mean score of 152 , shown in table 17 , was 76 percent of the possible weighted score of 200.

Category III, Individualized Instruction, ranked third among the nine categories. Item 9, Developing the Use of the Computer in the Classroom, ranked first in the category with 15 strongly agreed and 12 agreed responses. The item also had 8 which was the highest for undecided responses. Item 11, Creating Useful Remedial Materials, ranked second in the category. Both item 16, Implementing and Supervising Individualized Instruction, and item 15, Selecting and Developing Materials Activities Appropriate for Individualized Instruction, had 6 undecided responses with item 15 ranking last in the category. Category III consisted of 4 questionnaire items-$9,11,15$, and 16 . The mean score of 146 , shown in table 17 , was 73 percent of the possible weighted score of 200 .

Category I, Interpersonal Communication and Administration, ranked fourth among the nine categories. Item 28, Communicating and Interacting with Parents, ranked first in the category with 9 strongly agreed and 19 agreed responses. Item 25, Knowing Where to Refer Student Problems beyond what Can Be Handled by the Teacher, ranked second in the category with the highest number of strongly agree responses (10). Both of the above items had 3 undecided responses. Item 29, Counseling and Conferring with Studnets, had 
the highest number of agreed responses (21), while ranking last in the category. Category I consisted of 4 questionnaire items--25, 28,29 , and 30 . The mean score of 145 , shown in table 17, was 73 percent of the possible weighted score of 200 .

Category VIII, Non-Factor Related Items, ranked fifth among the nine categories. Item 1, Diagnosing Basic Learning Difficulties, ranked first in the category with 14 strongly agreed and 19 agreed responses. Item 14, Keeping Abreast of Developments in Your Own Subject Matter Area, ranked second in the category. Item 3, Identifying Student Disabilities That Need Referral or Special Remediai Work, had the same number of agreed and strongly agreed responses (14) while ranking third in the category. Item 17, Using Questioning Procedures that Promote Discussion, ranked fourth and had the highest number of agreed responses (24). Both item 41, Identifying the Gifted and Talented Students, and item 8 , Deciding What Teaching Technique Is Best for a Particuiar Intended Outcome, had the highest number of undecided responses (10). Category VIII consisted of 12 questionnaire items--1, 3, 4, 8, 10, $14,17,18,19,23,24$, and 41 . The mean score of 141 , shown in table 17, was 71 percent of the possible weighted score of 200 . Category $V$, Discipline, ranked sixth among the nine categories. Item 26, Useful Methods of Classroom Discipline and When to Use Them, ranked first in the category with 9 strongly agreed and 19 agreed responses. Item 27, Maintaining Classroom Control without Appearing as an Ogre to the Students, ranked second in the category with equal number of strongly agreed responses as item 26 (9). Each of the items had 2 teachers who strongly disagreed. Category $V$ 
consisted of 2 questionnaire items--26 and 27 . The mean score of 141, shown in table 17, was 70 percent of the possible weighted score of 200.

Category VI, Developing Personal Self, ranked seventh among the nine categories. Item 32, Developing a Broad Acceptance of Self, ranked first in the category with 5 strongly agreed, 18 agreed, and 11 undecided responses. Item 31 , Developing a Personal SelfEvaluation Method, ranked second in the category with the same number of undecided, agreed, and strongly agreed as item 32 . Item 34, Developing a Capacity of Accepting Others' Feelings, ranked last in the category with 17 disagreed responses. Category VI consisted of 3 questionnaire items--31, 32, and 34 . The mean score of 135, shown in table 17, was 68 percent of the possible weighted score of 200 .

Category IV, Assessment, ranked eighth among the nine categories. Item 12, Evaluating Instruction/Instructional Design, ranked first in the category with 4 strongly agreed and 22 agreed responses. Item 40, Developing or Modifying Instructional Procedures to Suit Your Own Strengths, ranked second in the category with same number of strongly agreed responses as item 12 . Item 2, Constructing and Using Tests for Evaluating Academic Progress, and item 5, Establishing Appropriate Performance Standards, both had 17 agreed responses, while item 33, Selecting and Specifying Performance Goals and Objectives, had 13 agreed and 13 disagreed responses while ranking last in the category. Category IV consisted of 6 questionnaire items-- $2,5,6,12,33$, and 40 . The mean 
score of 133, shown in table 17, was 66 percent of the possible weighted score of 200 .

Category VII, Classroom Management, ranked ninth among the nine categories. Item 21, Providing for Reinforcement, ranked first in the category with 3 strongly agreed and 18 agreed responses. Item 7, Teacher-Pupil Verbal Interaction, ranked second in the category with 12 undecided responses and a total of 12 disagree and strongly disagree responses. Item 21, Providing for Reinforcement, item 20, General Presentation of Information and Directions, and item 22, Deciding on Appropriate Pupil Grouping Procedures for Instruction, all had 8 undecided responses while both item 20 and item 22 had 2 strongly disagreed responses. Category VII consisted of 4 questionnaire items--7, 20, 21, and 22 . The mean score of 121 , shown in table 17, was 61 percent of the possible weighted score of 200 .

\section{Ranked Categories of Elementary Teachers} with $17-15$ Years of Experience

The description of the categories is presented in ranked order (table 18). Likewise, the description of the items within the categories is also presented in ranked order, according to the responses.

Category II, Developing Pupil Self, ranked first among the nine categories. Item 39, Instilling in the Student the Will to Learn on His Own Initiative, ranked first in the category with 11 strongly agreed and 11 agreed responses. Item 13, Motivating Students to Learn on Their Own, ranked second in the category with 12 agreed responses. Item 37, Facilitating Development of Pupil Responsibility, 
TABLE 18

A SUMMARY OF RANKED CATEGORIES OF LAKE UNION CONFERENCE ELEMENTARY TEACHERS WITH 11-15 YEARS OF EXPERIENCE

\begin{tabular}{|c|c|c|c|c|}
\hline & Categories & $\begin{array}{l}\text { Ranking } \\
\text { Order }\end{array}$ & $\begin{array}{l}\text { Mean of } \\
\text { Weighted } \\
\text { Score }\end{array}$ & $\begin{array}{c}\text { Percentage } \\
\text { of Possible } \\
\text { Weighted } \\
\text { Score }\end{array}$ \\
\hline 11 & Developing Pupil Self & 1 & 108 & 77 \\
\hline III & Individualized Instruction & 2 & 102 & 73 \\
\hline v & Discipline & 3 & 102 & 72 \\
\hline IX & Integration of Faith, Learning, and Practice & 4 & 101 & 72 \\
\hline VIII & Non-factor Related Items & 5 & 98 & 70 \\
\hline I & Interpersonal Communication and Administration & 6 & 96 & 69 \\
\hline VI & Developing Personal Self & 7 & 88 & 63 \\
\hline IV & Assessment & 8 & 87 & 62 \\
\hline VII & Classroom Management & 9 & 82 & 59 \\
\hline
\end{tabular}

*Maximum weighted score for this table was 140 [five times the number of teachers in the group]. 
also had 12 agreed responses. The two items above and item 38, Stinulating Growth of Pupil Attitudes and Values, all had the same number of disagree (4) and undecided (2) responses. No teacher strongly disagreed with any item of the category. Category II consisted of 5 questionnaire items $--13,35,36,37,38$, and 39 . The mean score of 108 , shown in table 18 , was 77 percent of the possible weighted score of 140 (28 teachers $\times 5)$.

Category III, Individualized Instruction, ranked second among the nine categories. Item 15, Selecting and Developing Materials Activities Appropriate for Individualized Instruction, ranked first in the category with 4 strongly agreed and 19 agreed responses. Item 16, Implementing and Supervising Individualized Instruction, ranked second in the category with highest number of agreed responses (20). Item 9, Developing the Use of the Computer in the Classroom, ranked last in the category with the same number of agreed and undecided responses ( 8 ). The item also had 3 strongly disagreed and 3 disagreed responses. Category III consisted of 4 questionnaire items--9, 11, 15, and 16 . The mean score of 102, shown in Table 18, was 73 percent of the possible weighted score of 140 . Category $V$, Discipline, ranked third among the nine categories. Item 26, Useful Methods of Classroom Discipline and When to Use Them, ranked first in the category with 6 strongly agreed and 12 agreed responses. Item 27, Maintaining Classroom Control without Appearing as an Ogre to the Students, ranked second in the category with the highest number of strongly agree responses (10). Category $V$ consisted of 2 questionnaire items--26 and 27 . The mean score of 102, shown in table 18, was 72 percent of the possible weighted score of 140. 
Category IX, Integration of Faith, Learning, and Practice, ranked fourth among the nine categories. Item 46; Making Bible Instruction More Applicable to Everyday Life, ranked first in the category with 10 strongly agreed and 10 agreed responses. Item 42, Deveioping a Better Understanding of the Theory of Integrating Faith, Learning, and Practice and What Makes It Work, ranked second in the category with the highest number of undecided responses (7). Item 42 also had 2 strongly disagree and 2 disagreed responses. Item 44, Constructing and Implementing a Christian Witness Program for Students and Teachers Together, ranked last with the highest number of agreed responses (16). Category IX consisted of 5 questionnaire items- $-42,43,44,45$, and 46 . The mean score of 101 , shown in table 18, was 72 percent of the possible weighted score of 140 .

Category VIII, Non-Factor Related Items, ranked fifth among the nine categories. Item 1, Diagnosing Basic Learning Difficulties, ranked first in the category with 8 strongly agreed and 12 agreed responses. Item 3, Identifying Student Disabilities That Need Referral of Special Remedial Work, ranked second in the category with the same number of agreed and strongly agreed responses as item 1. Item 4, Identifying Student Attitudes in Order to Better Relate to Problems, ranked third with the highest number of agreed responses (16). Both item 23, Constructively Using Evaluation in Helping Student Progress, and item 19, Gearing Instruction to Problem Solving, had the same number of undecided (4), agreed (14), and strongly agreed (4) responses. Item 17, Using Questioning Procedures that Promote Discussion, had the highest number of dis- 
agreed responses (12). Item 8 , Deciding that Teaching Technique Is Best for a Particular Intended Outcome, had equal number of undecided and agreed responses (10). Category VIII consisted of 12 questionnaire items--1, 3, 4, 8, 10, 14, 17, 18, 19, 23, 24, and 41 . The mean score of 98 , shown in table 18, was 70 percent of the possible weighted score of 140 .

Category I, Interpersonal Comunication and Administration, ranked sixth among the nine categories. Item 25, knowing where to Refer Student Problems beyond what Can Be Handled by the Teacher, ranked first in the category with 6 strongly agreed and 11 agreed responses. Item 28 , Communicating and Interacting with Parents, ranked second in the category with the highest number of agreed responses (15). Items 25, 28, and 29, Counseling and Conferring with Students, had one teacher who strongly disagreed with each item. Likewise, items 28,29 , and 30 , Involving others in the Schooi Program, all have 3 strongly agree responses. Category I consisted of 4 questionnaire items-- $25,28,29$, and 30 . The mean score of 96 , shown in table 18, was 69 percent of the possible weighted score of 140 .

Category VI, Developing Personal Self, ranked seventh among the nine categories. Item 31, Developing a Personal SelfEvaluation Method, ranked first in the category with 3 strongiy agreed and 11 agreed responses. Item 34, Developing a Capacity of Accepting Others' Feelings, ranked second in the category with the highest number of strongly agreed responses (5). Both $i$ tem 34 and item 32, Developing a Broad Acceptance of Self, had 3 strongly disagree, 7 undecided, and 8 agreed responses. Category VI con- 
sisted of 3 questionnaire items--31, 32, and 34 . The mean score of 88 , shown in table 18, was 63 percent of the possible weighted score of 140 .

Category IV, Assessment, ranked eighth among the nine categories. Item 40, Developing or Modifying Instructional Procedures to Suit Your Own Strengths, ranked first in the category with 3 strongly agreed and 13 agreed responses. Item 6, Involving Students in Self-Evaluation, ranked second in the category with the same number of strongly agreed responses as item 40 . Item 12, Evaluating Instruction/Instructional Design, had the highest number of undecided of responses (11), while item 33, Selecting and Specifying Performance Goals and Objectives, ranked last in the category with the highest number of disagreed responses (13). Category IV consisted of 6 questionnaire items--2, 5, 6, 12,33, and 40 . The mean score of 87 , shown in table 18, was 62 percent of the possible weighted score of 140 .

Category VII, Classroom Management, ranked ninth among the nine categories. Item 21, Providing for Reinforcement, ranked first in the category with one strongly agreed and 11 agreed responses. Item 22, Deciding on Appropriate Pupil Grouping Procedures for instruction, ranked second in the category with a total of 10 agreed and strongly agreed responses. Both item 22 and item 20, General Presentation of Information and Directions, had 8 undecided responses. Item 7 , Teacher-Pudil Verbal Interaction, ranked third in the category with the highest number of disagreed responses (13). Category VII consisted of 4 questionnaire items--7, 20, 21, and 22. The mean score of 82 , shown in table 18, was 59 percent of the possible weighted score of 140 . 
Ranked Categories of Elementary

Teachers with 16-20 Years of

Experience

The description of the categories is presented in ranked order (table 19). Likewise, the description of the items within the categories is also presented in ranked order, according to the responses.

Category IX, Integration of Faith, Learning, and Practice, ranked first among the nine categories. Item 46, Making Bible Instruction More Applicable to Everyday Life, ranked first in the category with 9 strongly agreed and 5 agreed responses. Item 44 , Constructing and Implementing a Christian Witness Program for Students and Teachers Together, ranked second in the category with 9 strongly agreed, 4 agreed, and 2 undecided responses. Item 44 and item 45, Transforming Faith into Action--By Vicarious Experience-Developing Christian Values and Attitudes, had the same number of agreed (4) and undecided responses (2). Likewise item 42, Developing a Better Understanding of the Theory of Integrating Faith, Learning, and Practice and What Makes It Work, also had 2 undecided responses. Item 43, Knowing How to Achieve Faith, Learning, and Practice from the Curriculum through Written Objectives and Evaluating Results, ranked last with the highest number of agreed (6) and undecided (3) responses. No teacher strongly disagreed with any item in this category. Category IX consisted of 5 questionnaire items $-42,43,44,45$, and 46 . The mean score of 64, shown in table 19, was 86 percent of the possible weighted score of 75 (15 teachers $\times 5)$.

Category II, Developing Pupil Self, ranked second among the 
TABLE 19

A SUMMARY OF RANKED CATEGORIES OF LAKE UNION CONFERENCE ELEMENTARY TEACHERS WITH 16-20 YEARS OF EXPERIENCE

\begin{tabular}{|c|c|c|c|c|}
\hline & Categories & $\begin{array}{l}\text { Ranking } \\
\text { Order }\end{array}$ & $\begin{array}{l}\text { Mean of } \\
\text { Weighted } \\
\text { Score }\end{array}$ & $\begin{array}{c}\text { Percentage } \\
\text { of Possible } \\
\text { Weighted } \\
\text { Score }\end{array}$ \\
\hline$I X$ & Integration of Faith, Learning, and Practice & 1 & 64 & 86 \\
\hline II & Developing Pupil Self & 2 & 63 & 83 \\
\hline 111 & Individualized Instruction & 3 & 59 & 78 \\
\hline v & Discipline & 4 & 57 & 76 \\
\hline I & Interpersonal Communication and Administration & 5 & 55 & 73 \\
\hline VI & Developing Personal Self & 6 & 54 & 72 \\
\hline VIII & Non-factor Related Items & 7 & 53 & 71 \\
\hline IV & As ses sment & 8 & 50 & 66 \\
\hline VII & Classroom Management & 9 & 48 & 64 \\
\hline
\end{tabular}

* Maximum weighted score for this table was 75 [five times the number of teachers in the group]. 
nine categories. Item 30, Involving Others in the School Program, ranked first in the category with 10 strongly agreed and 5 agreed responses. Item 13, Motivating Students to Learn on Their Own, ranked second in the category with no strongly disagreed or disagreed responses. Item 38, Stimulating Growth of Pupil Attitudes and Values, item 37, Facilitating Development of Pupil Responsibility, and item 35, Facilitating Pupil Self-Concept and Worth, all had 8 agreed responses. Two of the above items, 13 and 38, both had 6 strongly agreed responses. Also item 35 and item 36, Facilitating Pupil Social Interaction, had 3 strongly agreed responses. No teacher strongly disagreed with any item of this category. Category II consisted of 6 questionnaire items--13,30, $35,36,37$, and 38 . The mean score of 63 , shown in table 19, was 83 percent of the possible weighted score of 75 .

Category III, Individual Instruction, ranked third among the nine categories. Item 9, Developing the Use of the Computer in the Classroom, ranked first in the category with 7 strongly agreed and 3 agreed responses. Item 11, Creating Useful Remedial Materials, ranked second in the category with 9 agreed and 4 strongly agreed responses. Both items 15, Selecting and Developing Materials Activities Appropriate for Individualized Instruction, which ranked third in the category, and 16, Implementing and Supervising Individualized Instruction, which ranked last in the category, had 13 strongly agreed, 2 disagreed, and 0 strongly agreed responses. Category III consisted of 4 questionnaire items--9, 11, 15, and 16 . The mean score of 59 , shown in table 19, was 78 percent of the possible weighted score of 75 . 
Category V, Discipline, ranked fourth among the nine categories. Item 26, Useful Methods of Classroom Discipline and When to Use Them, ranked first in the category with 7 strongly agreed and 4 agreed responses. Item 27, Maintaining Classroom Control without Appearing as an Ogre to the Students, ranked second in the category with the same number strongly agreed (4) and undecided responses (3). No teacher strongly disagreed with any item of this category. Category $V$ consisted of 2 questionnaire items--26 and 27 . The mean score of 57, shown in table 19, was 76 percent of the possible weighted score of 75 .

Category I, Interpersonal Communication and Administration, ranked fifth among the nine categories. Item 30, Invoiving others in the School Program, ranked first in the category with 2 strongly agreed and 10 agreed responses. Item 28 , Communicating and Interacting with Parents, ranked second in the category with the highest number of strongly agreed responses (5). Item 25, Knowing where to Refer Student Problems beyond What Can Be Handled by the Teacher, ranked third in the category with the same number of strongly agreed (4) and undecided (3) responses as item 29, Counseling and Conferring with Students, which ranked last in the category. Category I consisted of 4 questionnaire items--25, 28, 29, and 30 . The mean score of 55 , shown in table 19, was 73 percent of the possible weighted score of 75 .

Category VI, Developing Personal Self, ranked sixth among the nine categories. Item 31, Developing a Personal Self-Evaluation Method, ranked first in the category with 4 strongly agreed and 7 agreed responses. Item 32, Developing a Broad Acceptance of Self, 
ranked second in the category with 4 strongly agreed, agreed, and undecided responses each. Item 34, Developing a Capacity of Accepting Others' Feelings, ranked last with 3 strongly agreed, agreed, and disagreed responses each. Category VI consisted of 3 questionnaire items--31, 32, and 34 . The mean score of 54 , shown in table 19, was 72 percent of the possible weighted score of 75 . Category VIII, Non-Factor Related Items, ranked seventh among the nine categories. Item 23, Constructively Using Evaluation in Helping Student Progress, ranked first in the category with 3 strongly agreed and 7 agreed responses. Item 24, Managing Classroom Affairs in Order to Get Maximum Benefit from Supervising, Aids, Tutors, etc., ranked second in the category with the highest number of strongly agreed responses (5). Item 19, Gearing Instruction to Problem Solving, item 10, Planning Teaching Activities with Other Teachers or Administrators, item 4, Identifying Student Attitudes in Order to Better Relate to Problems, item 41, Identifying the Gifted and Talented Students, item 18, Utilization of Audiovisual Equipment and Other Mechanical Aids, ali had 6 agreed responses each. Whereas items 3, Identifying Student Disabilities That Need Referral or Special Remedial Work, item 10, Planning Teaching Activities with Other Teachers or Administrators, item 17, Using Questioning Procedures That Promote Discussion, item 1 , Diagnosing Basic Learning Difficulties, item 14, Keeping Abreast of Developments in Your Own Subject Matter Area, item 8, Deciding What Teaching Technique Is Best for a Particular Intended Outcome, all had one undecided response. No teacher strongly disagreed with any item in this category. Category VIII consisted of 12 
questionnaire items $--1,3,4,8,10,14,17,18,19,23,24$, and 41. The mean score of 53 , shown in table 19, was 71 percent of the possible weighted score of 75 .

Category IV, Assessment, ranked eighth among the nine categories. Item 40, Developing or Modifying Instructional Procedures to Suit Your Own Strengths, ranked first in the category with 3 strongly agreed and 6 agreed responses. Item 6 , Involving Students in Self-Evaluation, ranked second in the category with a total of 9 strongly agreed and agreed responses. Item 5, Establishing Appropriate Performance Standards, ranked fourth with the highest number of agreed responses (9). Item 12, Evaluating Instruction/ Instructional Design, ranked last in the category with 0 strongly agreed and 0 strongly disagreed responses, 7 agreed and 7 disagreed responses and one undecided response. Category IV consisted of 6 questionnaire items--2, 5, 6, 12,33, and 40. The mean score of 50, shown in table 19, was 66 percent of the possible weighted score of 75 .

Category VII, Classroom Management, ranked ninth among the nine categories. Item 21, Providing for Reinforcement, ranked first in the category with 2 strongly agreed, 6 agreed, and 0 strongiy disagreed resoonses. Item 22, Deciding on Appropriate Pupil Grouping Procedures for Instruction, ranked second in the category with the same number of agreed (6), strongly agreed (2), and strongly disagreed (0) responses as item 21 . Item 7, Teacher-Pupil Verbal Interaction, ranked third in the category with 9 agreed and the same number of strongly agreed as strongly disagreed responses (1). Likewise, item 20, General Presentation of Information and 
Directions, also had the same number of strongly agreed as strongly disagreed (1), with 3 agreed and 3 undecided responses. Category VII consisted of 4 questionnaire items--7,20, 21, and 22 . The mean score of 48 , shown in table 19, was 64 percent of the possible weighted score of 75 .

Ranked Categories of Elementary

Teachers with $21+$ Years of

Experience

The description of the categories is presented in ranked order (table 20). Likewise, the description of the items within the categories is also presented in ranked order, according to the responses.

Category IX, Integration of Faith, Learning, and Practice, ranked first among the nine categories. Item 45, Transforming Faith into Action--By Vicarious Experience--Developing Christian Values and Attitudes, ranked first in the category with 12 strongly agreed and 18 agreed responses. Item 46, Making Bible Instruction More Applicable to Everyday Life, ranked second in the category with the highest number of strongly agreed responses (16). Item 42 , Developing a Better Understanding of the Theory of Integrating Faith, Learning, and Practice and What Makes it Work, ranked third in the category with the same number of agreed responses (18) as item 45 , which ranked first in the category. Of the 5 items in category IX, 2 teachers strongly disagreed with item 46, Making Bible Instruction More Applicable to Everyday Life, item 42, Developing a Better Understanding of the Theory of Integrating Faith, Learning, and Practice and What Makes It Work, item 44, Constructing and Implementing a Christian Witness Program for Students and Teachers 
TABLE 20

A SUMMARY OF THE RANKED CATEGORIES OF ELEMENTARY TEACHERS WITH $21+$ YEARS OF EXPERIENCE

\begin{tabular}{llll}
\hline \multicolumn{1}{c}{ Categories } & $\begin{array}{c}\text { Mean of } \\
\text { Ranking } \\
\text { Order }\end{array}$ & $\begin{array}{c}\text { Peighted } \\
\text { Score }\end{array}$ & $\begin{array}{c}\text { Peighted } \\
\text { Possible } \\
\text { Score }\end{array}$ \\
\hline IX Integration of Faith, Learning, and Practice & 1 & 140 & 78 \\
II Developing Pupil Self & 2 & 137 & 76 \\
III Individualized Instruction & 3 & 136 & 76 \\
VIII Non-factor Related Items & 4 & 124 & 69 \\
VI Developing Personal Self & 5 & 123 & 68 \\
IV Assessment & 6 & 121 & 67 \\
I Interpersonal Communication and Administration & 7 & 120 & 67 \\
VII Discipline Classroom Management & 8 & 120 & 67 \\
\hline
\end{tabular}
in the group]. 
Together, and item 43, Knowing How to Achieve Faith, Learning, and Practice from the Curriculum through Written Objectives and

Evaluating Results. One teacher disagreed with item 45, Transforming Faith into Action--by Vicarious Experience--Developing Christian Values and Attitudes. Category IX consisted of 5 questionnaire items- $-42,43,44,45$, and 46 . The mean score of 140 , shown in table 20 , was 78 percent of the possible weighted score of 180 (36 teachers $\times 5)$.

Category II, Developing Pupil Self, ranked second among the nine categories. Item.13, Motivating Students to Learn on Their Own, ranked first in the category with 14 strongly agreed and 12 agreed responses. Item 39, Instilling in the Student the Will to Learn on His Own Initiative, ranked second in the category with 14 strongly agreed responses. 8oth of the above items had 4 disagreed responses. Item 35, Facilitating Pupil Self-Concept and Worth, and item 38, Stimulating Growth of Pupil Attitudes and Values, each had 8 strongly agreed responses. Item 36, Facilitating Pupil Social Interaction, had 7 disagreed and 7 undecided responses. Category II consisted of 6 questionnaire items--13, $35,36,37,38$, and 39 . The mean score of 137, shown in table 20, was 76 percent of the possible weighted score of 180 .

Category III, Individualized Instruction, ranked third among the nine categories. Item 11, Creating Useful Remedial Materials, ranked first in the category with 9 strongly agreed and 18 agreed responses. Item 9, Developing the Use of the Computer in the Classroom, ranked second in the category with the highest number of strongly agreed responses (12). Item 9, item 15, Selecting and 
Developing Materials Activities Appropriate for Individualized Instruction, and item 16, Implementing and Supervising Individualized Instruction, each had 3 strongly disagreed and 2 disagreed responses. Item 16 had 22 agreed responses which was the highest number of responses in the category. Category III consisted of 4 questionnaire items--9, 11, 15, and 16. The mean score of 136, shown in table 20, was 76 percent of the possible weighted score of 180 .

Category VIII, Non-Factor Related Items, ranked fourth among the nine categories. Item 1, Diagnosing Basic Learning Difficulties, ranked first in the category with 9 strongly agreed and 17 agreed responses. Item 3, Identifying Student Disabilities that Need Referral or Special Remedial Work, ranked second in the category with the same number of responses as item 1 which ranked first. Because the items had identical responses the two items were listed numerically. Item 14, Keeping Abreast of Developments in Your Own Subject Matter Area, ranked third in the category with the same number of strongly agreed responses (9) and strongly disagreed responses (1) as items 1 and 3. Item 19, Gearing Instruction to Problem Solving, and item 4, Identifying Student Attitudes in Order to Better Relate to Problems, ranked sixth and seventh with 19 agreed and 5 strongly agreed responses each. Item 17, Using Questioning Procedures That Promote Discussion, ranked last in the Category with 7 strongly disagreed and 7 disagreed responses each. Category VIII consisted of 12 questionnaire items--1, 3, $4,8,10,14,17,18,19,23,24$, and 41 . The mean score of 124 , shown in table 20, was 69 percent of the possible weighted score of 180 . 
Category VI, Developing Personal Self, ranked fifth among the nine categories. Item 34, Developing a Capacity of Accepting Others' Feelings, ranked first in the category with 7 strongly agreed and 16 agreed responses. Item 32, Developing a Broad Acceptance of Self, ranked second in the category with 7 strongly agreed and 7 disagreed responses. Item 31, Developing a Personal Self-Evaluation Method, ranked last in the category with the highest number of agreed responses. Both items 34 and 32 had 3 strongly disagreed and 4 undecided responses. Item 32 and item 31 each had 7 disagreed responses. Category VI consisted of 3 questionnaire items--31, 32, and 34. The mean score of 123, shown in table 20, was 68 percent of the possible weighted score of 180 .

Category IV, Assessment, ranked sixth among the nine categories. Item 40, Developing or Modifying Instructional Procedures to Suit Your Own Strengths, ranked first in the category with 4 strongly agreed and 20 agreed responses. Item 6 , Involving Students in Self-Evaluation, ranked second in the category with the same number of strongly agreed (4), disagreed (6), and strongly disagreed (2) responses as item 40 , which ranked first in the category. I tem 12, Evaluating Instruction/Instructional Design, ranked third in the category with no teacher who strongly disagreed with the item. Item 33, Selecting and Specifying Performance Goals and Objectives, had 3 strongly agreed and 3 strongly disagreed responses, while item 5, Establishing Appropriate Performance Standards, and item 2, Constructing and Using Tests for Evaluating Academic Progress, each had 15 agreed responses. Category IV consisted of 6 question- 
naire items- $-2,5,6,12,33$, and 40 . The mean score of 121 , shown in table 20 , was 67 percent of the possible weighted score of 180 .

Category I, Interpersonal Communication and Administration, ranked seventh among the nine categories. Item 29, Counseling and Conferring with Students, ranked first in the category with 8 strongly agreed and 18 agreed responses. Item 30, Involving Others in the School Program, ranked second in the category with 3 strongly agree and 3 strongly disagree responses each. The category al so had the highest number of agreed responses (19). Item 25, Knowing Where to Refer Student Problems beyond What Can Be Handled by the Teacher, had 11 agreed and disagreed responses each. Category I consisted of 4 questionnaire items--25, 28, 29, and 30 . The mean score of 120 , shown in table 20 , was 67 percent of the possible weighted score of 180 .

Category V, Discipline, ranked eighth among the nine categories. Item 27, Maintaining Classroom Control without Appearing as an Ogre to the Students, ranked first in the category with 7 strongly agreed and 13 agreed responses. Item 26, Useful Methods of Classroom Discipline and When to Use Them, ranked second in the category with the highest number of strongly agreed responses (8) in the category. Category $V$ consisted of 2 questionnaire items-26 and 27 . The mean score of 120 , shown in table 20 , was 67 percent of the possibie weighted score of 180 .

Category VII, Classroom Management, ranked ninth among the nine categories. Item 21, Providing for Reinforcement, ranked first in the category with 6 strongly agreed and 13 agreed responses. 
Item 22, Deciding on Appropriate Pupil Grouping Procedures for Instruction, ranked second in the category. Both item 7, TeacherPupil Verbal Interaction, and item 20, General Presentation of Information and Directions, had 2 strongly agreed and 4 strongly disagreed responses each. Category VII consisted of 4 questionnaire items $-7,20,21$, and 22 . The mean score of 110 , shown in table 20, was 61 percent of the possible weighted score of 180 .

Summary--Elementary Teachers by

Years of Experience

Research questions 8 (What are the perceived inservice needs of Lake Union Conference elementary teachers who have taught 0-5 years?), 9 (What are the perceived inservice needs of Lake Union Conference elementary teachers who have taught 6-10 years?), 10 (What are the perceived inservice needs of Lake Union Conference elementary teachers who have taught $11-15$ years?), 11 (What are the perceived inservice needs of Lake Union Conference elementary teachers who have taught $16-20$ years?), and 12 (What are the perceived inservice needs of Lake Union Conference elementary teachers who have taught $21+$ years?) as posed in chapter III are addressed in the presentation of the responses of 5 groups of Lake Union Conference elementary teachers; those who had taught 0-5 years, 6-10 years, 11-15 years, $16-20$ years, and $21+$ years. In addition, the above responses were compared to all the elementary teachers of the Lake Union Conference (fig. 5 and table 21).

Category IX, Integration of Faith, Learning, and Practice, was ideritified as the first perceived inservice need by elementary teachers who had taught $6-10,16-20$, and $21+$ years. Teachers with 


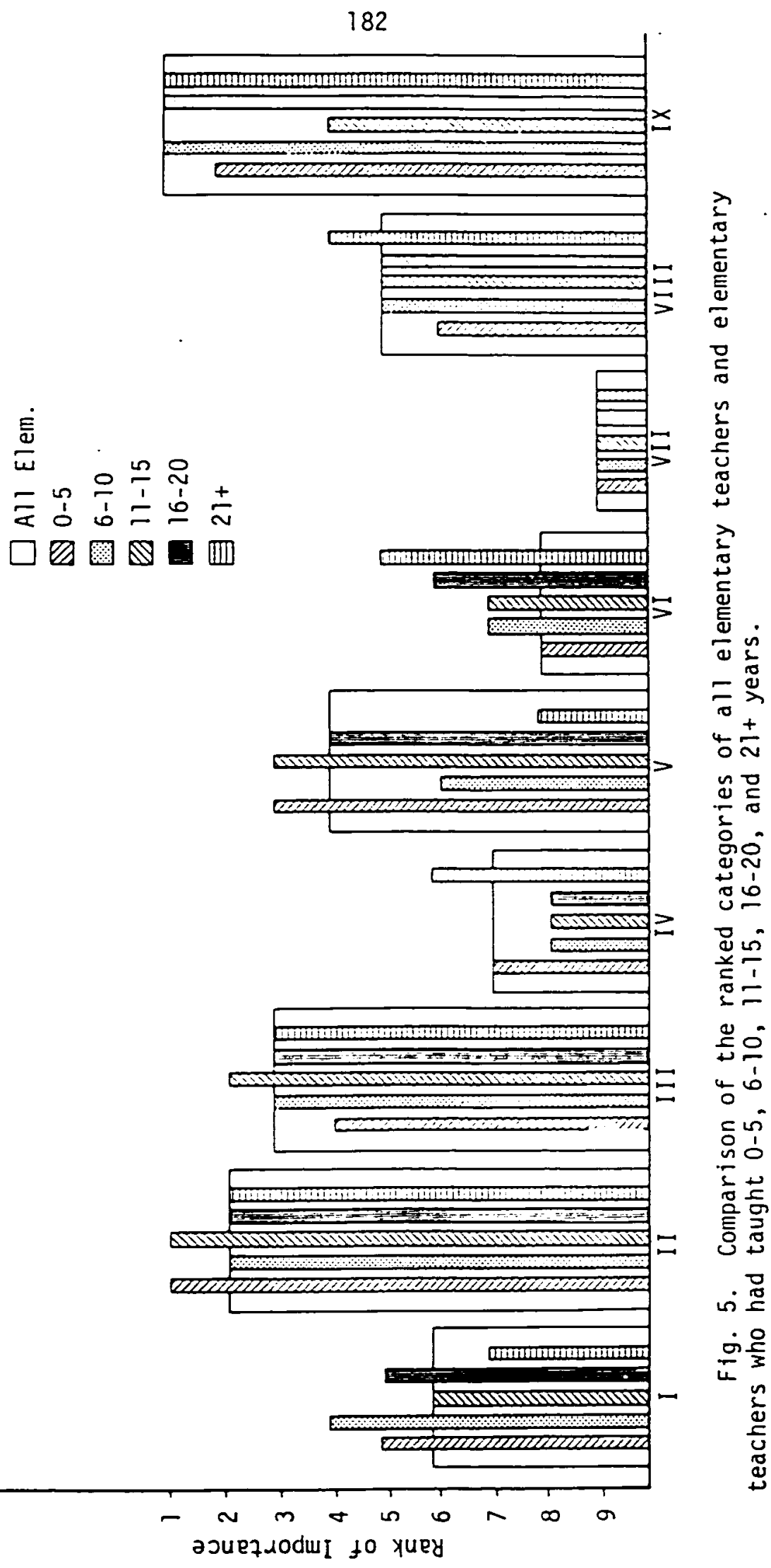


TABLE 21

A COMPARISON OF RANKED CATEGORIES OF ALL ELEMENTARY TEACHERS AND ELEMENTARY TEACHERS WHO HAD TAUGHT 0-5, 6-10, $11-15,16-20$, AND $21+$ YEARS

\begin{tabular}{lccccccccc}
\hline \hline $\begin{array}{c}\text { Years of } \\
\text { Experience }\end{array}$ & \multicolumn{10}{c}{ Categories } \\
\cline { 2 - 9 } AlI Elementary & I & II & III & IV & V & VI & VII & VIII & IX \\
$0-5$ & 6 & 2 & 3 & 7 & 4 & 8 & 9 & 5 & 1 \\
$6-10$ & 5 & 1 & 4 & 7 & 3 & 8 & 9 & 6 & 2 \\
$11-15$ & 4 & 2 & 3 & 8 & 6 & 7 & 9 & 5 & 1 \\
$16-20$ & 6 & 1 & 2 & 8 & 3 & 7 & 9 & 5 & 4 \\
$21+$ & 5 & 2 & 3 & 8 & 4 & 6 & 9 & 5 & 1 \\
\hline
\end{tabular}

0-5 years experience ranked it second, teachers with 11-15 years of experience ranked the category fourth, whereas all elementary teachers ranked it first.

Category II, Developing Pupil Self, was ranked second by teachers who had taught $6-10,16-20$, and $21+$ years. Elementary teachers who had taught $0-5$ and 11-15 years ranked the category first, whereas all elementary teachers ranked it second.

Category III, Individualized Instruction, was ranked third by teachers who had taught 6-10 years, 16-20 years, and 21+ years. The category was ranked fourth by teachers who had taught $0-5$ years and second by teachers who had taught 11-15 years, whereas all elementary teachers ranked it third. The remaining categories varied by one or two rankings except category VII, Classroom Management, was ranked last by all 
the elementary teachers with the different years of experience as well as all elementary teachers as a group.

\section{Secondary Teachers by Teaching \\ Assignment}

Ranked Items by Secondary Subject

Matter Teachers

Of the 142 secondary teachers employed by the Lake Union Conference, a total of 63 teachers returned their completed questionnaire. Three of the questionnaires were not used: one respondent who was the only respondent from that subject matter field "strongly agreed" with all items except eight and those were marked "agreed." The other two respondents indicated they taught in the social service area which does not exist in the Lake Union Conference secondary schools.

The secondary subjects are listed in alphabetical and numerical order. A breakdown of the returns subject matter is as follows:

\begin{tabular}{|c|c|c|}
\hline 1. & Art & - \\
\hline 2. & Bible & - \\
\hline 3. & Business Education & - \\
\hline 4. & Counsellors & - \\
\hline 5. & English & - \\
\hline 6. & Home Economics & - \\
\hline 7. & Industrial Arts & - \\
\hline 8. & Librarian & - \\
\hline 9. & Mathematics & - \\
\hline & Music & - \\
\hline
\end{tabular}




$$
\begin{array}{ll}
\text { 11. Physical Education } & -7 \\
\text { 12. Science } & -10 \\
\text { 13. Foreign Language } & -2 \\
\text { 14. Social Studies } & -9 \\
\text { 15. Vocational Education } & -2 \\
\text { 16. Other } & -2
\end{array}
$$

Identified as the first perceived inservice need, item 13, Motivating Students to Learn on Their Own, was ranked in the top six inservice needs by teachers in eleven of the sixteen disciplines (table 22). This item was also ranked as the first perceived inservice need by all the secondary teachers and as the second most important inservice need by all the $k-12$ teachers. Item 13 is from Category II, Developing Pupil Self.

Identified as the second perceived inservice need, item 14 , Keeping Abreast of Developments in Your Own Subject Matter Area, was ranked in the top six inservice needs by teachers in nine of the sixteen disciplines. This was two fewer disciplines than item 13 which ranked first. The item was also ranked second by the secondary teachers, but first by all the $k-12$ teachers. Item 14 , is from category VIII, Non-Factor Related Items.

Identified as the third perceived need were item 9, Developing the Use of Computers in the Classroom, item 29, Counseling and Conferring with Students, and item 44 , Constructing and Implementing a Christian Witnessing Program for Students and Teachers Together. The above three items tied for third place. Each item was ranked in the top six by teachers from five of the sixteen disciplines. item 9 was ranked seventh by all the $\mathrm{K}-12$ teachers and eleventh by the 
TABLE 22

TOP SIX ITEMS AS RANKED BY SECONDARY SUBJECT TEACHERS

\begin{tabular}{|c|c|c|c|c|c|c|c|c|c|c|c|c|c|c|c|c|}
\hline \multirow{2}{*}{ I tems } & \multicolumn{16}{|c|}{ Secondary Subject } \\
\hline & 1 & 2 & 3 & 4 & b & & & & & & & 12 & 13 & 14 & 15 & 16 \\
\hline 1 & & & & & & & & & & & & & 6 & & & \\
\hline $\begin{array}{l}2 \\
3\end{array}$ & & & & & 1 & & & & & & & & & & & \\
\hline 4 & 1 & 1 & & & & & & & & & & & 1 & & & 1 \\
\hline $\begin{array}{l}5 \\
6\end{array}$ & & & & & & & & & & & & & & & & \\
\hline $\begin{array}{l}6 \\
7\end{array}$ & 6 & 6 & & & & 4 & & & & 2 & & & & & & \\
\hline 8 & & & & & 2 & & & & 6 & & & & & & & \\
\hline 10 & & & & & & & 6 & 1 & 1 & & & 3 & & 3 & & \\
\hline $\begin{array}{l}10 \\
11\end{array}$ & & & & & & & & & & & & & & & & \\
\hline 12 & & & & & 5 & & 1 & & & & & & & 2 & & \\
\hline 13 & & 2 & 1 & 1 & 3 & 2 & & 2 & 2 & 3 & & 5 & 2 & 1 & & \\
\hline 14 & & 2 & 1 & 5 & & 1 & & 3 & & & & 1 & 3 & 4 & 1 & \\
\hline $\begin{array}{l}15 \\
16\end{array}$ & & & 2 & & & & 2 & & & & & & & 5 & & \\
\hline 17 & & & & & & & & & & & & & & & & \\
\hline $\begin{array}{l}18 \\
19\end{array}$ & & & & & & & & & & & & & & & 6 & \\
\hline $\begin{array}{l}19 \\
20\end{array}$ & & & & $\begin{array}{l}4 \\
1\end{array}$ & & & & & & & & & & & & \\
\hline $\begin{array}{l}21 \\
22\end{array}$ & & & & & & & & & & & & & & & & \\
\hline $\begin{array}{l}22 \\
23\end{array}$ & & & & & & & & & & & & & & & & \\
\hline $\begin{array}{l}23 \\
24\end{array}$ & & & & & 4 & & & & & 4 & & & & 6 & & \\
\hline $\begin{array}{l}25 \\
26\end{array}$ & & & & & & & & & & 5 & & & & & & \\
\hline $\begin{array}{l}26 \\
27\end{array}$ & & & 3 & & & & & & & & 6 & & 4 & & & \\
\hline 28 & 2 & & & & & & & & & 6 & & & 5 & & & 2 \\
\hline 29 & & 3 & & & 6 & 5 & & & & & 4 & & & & & 3 \\
\hline $\begin{array}{l}30 \\
31\end{array}$ & & & & & & & & & & & & & & & & \\
\hline $\begin{array}{l}31 \\
32\end{array}$ & & 4 & & & & & & & 3 & & & & & & & \\
\hline 33 & & & & & & & & & & & & & & & & \\
\hline 34 & & & & & & & & & & & & & & & & \\
\hline 35 & & & & & & 3 & 3 & & & & & & & & & \\
\hline 37 & 3 & & 4 & & & & 4 & 4 & & & & & & & & \\
\hline 38 & 4 & & & 6 & & & $i$ & & & & & 4 & & & & \\
\hline $\begin{array}{l}39 \\
40\end{array}$ & 5 & & & & & & & 5 & $\begin{array}{l}5 \\
4\end{array}$ & & & 2 & & & & \\
\hline 41 & & & 5 & & & & & & & & & & & & & \\
\hline 42 & & & & & & & 5 & 6 & & & 5 & 6 & & & & \\
\hline 43 & & & 6 & & & & & & & & & & & & 2 & 4 \\
\hline 44 & & & & 2 & & & & & & 1 & 3 & & & & 3 & 5 \\
\hline 45 & & 5 & & & & & & & & & & & & & 4 & 6 \\
\hline 46 & & & & 3 & & & & & & & 2 & & & & 5 & \\
\hline
\end{tabular}


secondary teachers, whereas, item 29 was ranked twentieth by the secondary teachers and twenty-fourth by the $K-12$ teachers. Item 44 was ranked fifth by the secondary teachers and sixth by the $k-12$ teachers. The above items are from category III, Individualized Instruction; category I, Interpersonal Communication and Administration; and category IX, Integration of Faith, Learning, and Practice.

Sumary--Secondary Teachers by Teaching Assignment

Research question number 7 (What are the perceived inservice needs of Lake Union Conference secondary teachers who teach the different disciplines [i.e., math, Bible, history]?), as posed in chapter III, is addressed in the presentation of the responses of the secondary teachers who teach different disciplines such as art, Bible, English, social studies, etc. (table 23).

Category IX, Integration of Faith, Learning, and Practice, was identified as the first perceived inservice need by the teachers who teach Bible, business education, English, and vocational education, and others (table 23). The category was also perceived as the first inservice need by counselors and librarians. Perceiving it as the second inservice need were the physical education, science, foreign language, and social studies teachers. Category III, Individualized Instruction, was identified as the first perceived inservice need by the industrial arts, math, and social studies teachers, whereas Category V, Discipline, was identified as the first perceived inservice need by the home economics, physical education, and foreign language teachers. 
TABLE 23

A COMPARISON OF RANKED CATEGORIES OF SECONDARY SUBJECT MATTER TEACHERS

\begin{tabular}{|c|c|c|c|c|c|c|c|c|c|}
\hline \multirow{2}{*}{$\begin{array}{r}\text { Secondary } \\
\text { Subjects }\end{array}$} & \multicolumn{9}{|c|}{ Categories } \\
\hline & I & II & III & IV & $V$ & VI & VII & VIII & IX \\
\hline A $11 \mathrm{~K}-12$ & 6 & 2 & 3 & 7 & 4 & 8 & 9 & 5 & \\
\hline All secondary & 8 & 2 & 4 & 7 & 3 & 6 & 9 & 5 & . \\
\hline 1. Art & 2 & 1 & 8 & 7 & 4 & 5 & 9 & 6 & 3 \\
\hline 2. Bible & 5 & 2 & 6 & 7 & 9 & 3 & 8 & 4 & \\
\hline 3. Business Education & 4 & 3 & 8 & 6 & 2 & 7 & 9 & 5 & \\
\hline 4. Counsellor & 6 & 3 & 7 & 8 & 2 & 4 & 9 & 5 & \\
\hline 5. English & 7 & 2 & 4 & 6 & 9 & 8 & 5 & 3 & \\
\hline 6. Home Economics & 7 & 2 & 9 & 5 & 1 & 3 & 8 & 6 & \\
\hline 7. Industrial Arts & 4 & 2 & 1 & 7 & 9 & 5 & 8 & 6 & \\
\hline 8. Librarian & 7 & 2 & 3 & 6 & 4 & 8 & 9 & 5 & \\
\hline 9. Mathematics & 8 & 3 & 1 & 7 & 4 & 2 & 9 & 6 & \\
\hline 10. Music & 1 & 5 & 7 & 4 & 2 & 9 & 8 & 6 & . \\
\hline 11. Physical Education & 4 & 9 & 3 & 8 & 1 & 5 & 7 & 6 & $a$ \\
\hline 12. Science & 8 & 1 & 4 & 6 & 3 & 7 & 9 & 5 & 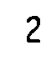 \\
\hline 13. Foreign Language & 9 & 4 & 5 & 6 & 1 & 7 & 8 & 3 & 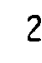 \\
\hline 14. Social Studies & 8 & 3 & 1 & 5 & 7 & 6 & 9 & 4 & 2 \\
\hline 15. Vocational Education & 7 & 5 & 8 & 6 & 2 & 3 & 9 & 4 & \\
\hline 16. Other & 2 & 3 & 9 & 7 & 5 & 4 & 6 & 8 & \\
\hline
\end{tabular}


Category II, Developing Pupil Self, was ranked second by Bible, English, home economics, industrial arts teachers, and librarians. The other rankings of the category varied with the art teachers ranking category II as the first perceived inservice need and the physical education teachers ranking the category last.

The remaining categories varied in perceived need rankings. Category VII, Classroom Management, was ranked eighth or ninth by teachers of all subjects except English teachers who ranked the category fifth, others who ranked it sixth, and physical education teachers who ranked it seventh.

\section{Ranked Categories of Secondary Teachers by Years of Experience}

Ranked Categories of Secondary Teachers with $0-5$ Years of Experience

The description of the categories is presented in ranked order (table 24). Likewise, the description of the items within the categories is also presented in ranked order, according to the responses.

Category IX, Integration of Faith, Learning, and Practice, ranked first among the nine categories. Item 46, Making Bible Instruction More Applicable to Everyday Life, ranked first in the category with 8 strongly agreed and 3 agreed responses. Item 45 , Transforming Faith into Action--by Vicarious Experience--Developing Christian Values and Attitudes, ranked second in the category with the same number of strongly agreed (8) and undecided responses (2) as the item which ranked first in the category. Item 42, Developing a Better Understanding of the Theory of Integrating Faith, Learning, 
TABLE 24

A SUMMARY OF RANKED CATEGORIES OF SECONDARY TEACHERS WHO HAD TAUGHT 0-5 YEARS

\begin{tabular}{lllc}
\hline \multicolumn{1}{c}{ Categories } & $\begin{array}{c}\text { Ranking } \\
\text { Order }\end{array}$ & $\begin{array}{c}\text { Mean of } \\
\text { Weighted } \\
\text { Score }\end{array}$ & $\begin{array}{c}\text { Percentage } \\
\text { of Possible } \\
\text { Weighted } \\
\text { Score }\end{array}$ \\
\hline IX Integration of Faith, Learning, and Practice & 1 & 77 & 85 \\
II Developing Pupil Self & 2 & 75 & 84 \\
VI Developing Personal Self & 3 & 70 & 78 \\
V Discipline & 4 & 69 & 77 \\
VIII Non-factor Related Items & 5 & 68 & 76 \\
III Individualized Instruction & 6 & 67 & 73 \\
I Interpersonal Communication and Administration & 7 & 66 & 73 \\
VII Assessinent & 8 & 65 & 68 \\
\hline
\end{tabular}

*Maximum weighted score for this table was 90 [five times the number of teachers in the group]. 
and Practice and What Makes It Work, ranked third in the category with the highest number of strongly agreed responses (9) in the category. The item also had 4 each of agreed and undecided responses. Item 43, Knowing How to Achieve Faith, Learning, and Practice from the Curriculum through Written Objectives and Evaluating Results, ranked last in the category with the highest number of agreed responses (11). Category IX consisted of 5 questionnaire items-$42,43,44,45$, and 46 . The mean score of 77 , shown in table 24 , was 85 percent of the possible weighted score of 90 (18 teachers $\times 5)$. Category II, Developing Pupil Self, ranked second among the nine categories. Item 13, Motivating Students to Learn on Their Own, ranked first in the category with 10 strongly agreed and 7 agreed responses. Item 35, Facilitating Pupil Self-Concept and Worth, ranked second in the category with 7 agreed and 9 strongly agreed responses. The above items had no teachers who were undecided or strongly disagreed with these items. Item 36 , Facilitating Pupil Social Interaction, ranked last in the category. Category II consisted of 6 questionnaire items--13, 35, 36, 37, 38, and 39. The mean score of 75 , shown in table 24 , was 84 percent of the possibie weighted score of 90 .

Category VI, Developing Personal Self, ranked third among the nine categories. Item 31, Developing a Personal Self-Evaluation Method, ranked first in the category with 3 strongly agreed and 11 agreed responses. Item 32, Developing a Broad Acceptance of Self, ranked second in the category with 4 strongly agreed responses. Both item 32 and item 34, Geveloping a Capacity of Accepting Others' Feelings, had 6 undecided responses. Category VI consisted of 
3 questionnaire items--31, 32, and 34 . The mean score of 70 , shown in table 24 , was 78 percent of the possible weighted score of 90 .

Category $V$, Discipline, ranked fourth among the nine categories. Item 27, Maintaining Classroom Control without Appearing as an Ogre to the Students, ranked first in the category with 4 strongly agreed and 10 agreed responses. Item 26, Useful Methods of Classroom Discipline and When to Use Them, ranked second in the category. Both items had 10 agreed, 2 undecided, and 2 disagreed responses. Category $V$ consisted of 2 questionnaire items--26 and 27 . The mean score of 69 , shown in table 24 , was 77 percent of the possible weighted score of 90 .

Category VIII, Non-Factor Related Items, ranked fifth among the nine categories. Item 14, Keeping Abreast of Developments in Your Own Subject Matter Area, ranked first in the category with 14 Strongly agreed and 4 agreed, 0 undecided, and 9 disagreed responses. Item 23, Constructively Using Evaluation in Helping Student Progress, ranked second in the category with the highest number of agreed responses (11) and 0 strongly disagreed responses. Six items, item 19, Gearing Instruction to Problem Solving, item 1, Diagnosing Basic Learning Difficulties, item 10, Planning Teaching Activities with Other Teachers or Administrators, item 3, Identifying Student Disabilities That Need Referral or Special Remedial Work, item 18, Utilization of Audiovisual Equipment and Other Mechanical Aids, and item 4, Identifying Student Attitudes in Order to Better Relate to Problems, which ranked fourth through ninth all had 4 strongly agreed responses. Category VIII consisted 
of 12 questionnaire items $--1,3,4,8,10,14,17,18,19,23,24$, and 41 . The mean score of 68 , shown in table 24 , was 76 percent of the possible weighted score of 90 .

Category III, Individualized Instruction, ranked sixth among the nine categories. Item 15, Selecting and Developing Materials Activities Appropriate for Individualized Instruction, ranked first in the category with 3 strongly agreed and 9 agreed responses. Item 9, Developing the Use of the Computer in the Classroom, ranked second in the category with the highest number of strongly agreed responses (7). Item 16, Implementing and Supervising Individualized Instruction, ranked third with 8 undecided, 2 strongly agreed, and a total of 2 strongly disagreed responses. Item 11 , Creating Usefui Remedial Materials, had 5 agreed, 5 undecided, and 5 disagreed responses and ranked last in the category. Category III consisted of 4 questionnaire items--9, 11, 15, and 16. The mean score of 67 , shown in table 24 , was 75 percent of the possible weighted score of 90 .

Category I, Interpersonal Communication and Administration, ranked seventh among the nine categories. Item 29, Counseling and Conferring with Students, ranked first in the category with 7 strongly agreed and 8 agreed responses. Item 28, Communicating and Interacting with Parents, ranked second in the category with 5 strongly agreed, 4 undecided, and 4 disagreed responses. Item 30, Involving Others in the School Program, and item 25, Knowing where to Refer Student Problems beyond What Can Be Handled by the Teacher, had 3 disagreed and 6 undecided responses each. Category I consisted of 4 questionnaire items--25, 28, 29, and 30 . The mean 
score of 66 , shown in table 24 , was 73 percent of the possible weighted score of 90 .

Category IV, Assessment, ranked eighth among the nine categories. Item 40, Developing or Modifying Instructional Procedures to Suit Your Own Strengths, ranked first in the category with 4 strongly agreed and 7 agreed responses. Item 6, Involving Students in Self-Evaluation, ranked second in the category with 3 strongly agreed, 3 undecided, and 3 disagreed responses. No teacher strongly disagreed with the above two items. Both item 12, Evaluating Instruction/Instructional Design, and item 2, Constructing and Using Tests for Evaluating Academic Progress, had 10 agreed responses. Item 2 also had 2 strongly agreed and 2 strongly disagreed items. Item 5, Establishing Appropriate Performance Standards, which ranked last had no teacher who strongly disagreed or strongly agreed with the item. Category IV consisted of 6 questionnaire items--2, 5, 6, 12, 33, and 40. The mean score of 65, shown in table 24, was 73 percent of the possible weighted score of 90 . Category VII, Classroom Management, ranked ninth among the nine categories. Item 7, Teacher-Pupil Verbal Interaction, ranked first in the category with 4 strongly agreed and 9 agreed responses. Item 21, Providing for Reinforcement, ranked second in the category with 3 strongly agreed and 3 disagreed responses. Item 22, Deciding on Appropriate Pupil Grouping Procedures for Instruction, had one strongly agreed and one strongly disagreed response. Item 20 , General Presentation of Information and Directions, ranked last with 10 undecided responses which was the highest for the category. Category VII consisted of 4 questionnaire items--7, 20, 21, and 22. 
The mean score of 61 , shown in table 24 , was 68 percent of the possible weighted score of 90 .

Ranked Categories of Secondary

Teachers with 6-10 Years of

Experience

The description of the categories is presented in ranked order (table 25). Likewise, the description of the items within the categories is also presented in ranked order, according to the responses.

Category IX, Integration of Faith, Learning, and Practice, ranked first among the nine categories. Item 44, Constructing and Implementing a Christian Witness Program for Students and Teachers Together, ranked first in the category with 7 strongly agreed and 6 agreed responses. Item 42, Developing a Better Understanding of the Theory of Integrating Faith, Learning, and Practice and What Makes It Work, ranked second in the category with the same number of strongly agreed (7) and agreed responses (6) as item 44 which ranked first in the category. Both item 45, Transforming Faith into Action--by Vicarious Experience--Developing Christian Values and Attitudes, and item 46, Making Bible Instruction More Applicable to Everyday Life, had the same number of strongly disagreed (0), disagreed (1), undecided (1), agreed (7), strongly agreed (6) responses. Item 43, Knowing How to Achieve Faith, Learning and Practice from the Curriculum through Written Objectives and Evaluating Results, ranking fifth in the category also had 6 strongly agreed responses. No teacher strongly disagreed with any item in the category. Category IX consisted of 5 questionnaire items-- 42,43 , 
TABLE 25

A SUMMARY OF RANKED CATEGORIES OF THE LAKE UNION CONFERENCE SECONDARY TEACHERS WHO TAUGHT 6-10 YEARS

\begin{tabular}{llll}
\hline \multicolumn{1}{c}{ Categories } & $\begin{array}{c}\text { Ranking } \\
\text { Order }\end{array}$ & $\begin{array}{c}\text { Mean of } \\
\text { Weighted } \\
\text { Score }\end{array}$ & $\begin{array}{c}\text { Percentage } \\
\text { of Possible } \\
\text { Weighted } \\
\text { Score }\end{array}$ \\
\hline IX Integration of Faith, Learning, and Practice & 1 & 63 & 84 \\
II Developing Pupil Self & 2 & 60 & 80 \\
IV Assessment & 3 & 56 & 74 \\
III Individualized Instruction & 4 & 55 & 74 \\
VIII Non-factor Related Items & 5 & 55 & 73 \\
V Discipline & 6 & 54 & 73 \\
I Interpersonal Communication and Administration & 7 & 54 & 72 \\
VI Developing Personal Self & 8 & 52 & 69 \\
VII Classroom Management & 9 & 46 & 61 \\
\hline
\end{tabular}

*Maximum weighted score for this table was 75 [five times the number of teachers in the group]. 
44,45 , and 46 . The mean score of 63 , shown in table 25 , was 84 percent of the possible weighted score of 75 ( 15 teachers $\times 5)$. Category II, Developing Pupil Self, ranked second among the nine categories. Item 39, Instilling in the Student the Will to Learn on His Own Initiative, ranked first in the category with 8 strongly agreed and 5 agreed responses. Item 13, Motivating Students to Learn on Their Own, ranked second in the category with the highest number of agreed responses (10). Item 37, facilitating Development of Pupil Responsibility, and item 38, Stimulating Growth of Pupil Attitudes and Values, had the same number of strongly disagreed ( 1 ), disagreed (1), undecided ( 0$)$, agreed (7), and strongly agreed (6) responses. Item 35, Facilitating Pupil Self-Concept and Worth, also had only one strongly disagreed, one disagreed, and 0 undecided responses as the above two items. Item 36, Facilitating Pupil Social Interaction, ranked last in the category with 5 agreed and 5 disagreed responses. Category II consisted of 6 questionnaire items- $-13,35,36,37,38$, and 39 . The mean score of 60 , shown in table 25 , was 80 percent of the possible weighted score of 75 .

Category IV, Assessment, ranked third among the nine categories. Item 40, Developing or Modifying Instructional Procedures to Suit Your Own Strengths, ranked first in the category with 3 strongly agreed and 10 agreed responses. Item 6 , Involving Students in Self-Evaluation, ranked second in the category with the same number of agreed (9) and strongly agreed (3) responses as item 33, Selecting and Specifying Performance Goals and Objectives, which ranked third in the category. Item 2, Constructing and Using Tests 
for Evaluating Academic Progress, had 2 strongly agreed and 2 undecided responses and ranked last in the category. Category IV consisted of 6 questionnaire items--2, 5, 6, 12,33, and 40. The mean score of 56 , shown in table 25 , was 74 percent of the possible weighted score of 75 .

Category III, Individualized Instruction, ranked fourth among the nine categories. Item 15, Selecting and Developing Materials Activities Appropriate for Individualized Instruction, ranked first in the category with 3 strongly agreed and 8 agreed responses. Item 11, Creating Useful Remedial Materials, ranked second in the category with 3 strongly agreed and 3 undecided responses each. Item 16, Implementing and Supervising Individualized Instruction, ranked third with the highest number of undecided responses (4). Item 9, Identifying Student Attitudes in Order to Better Relate to Problems, ranked last with 3 agreed and 3 undecided responses and the highest number of strongly agreed responses (5). Category III consisted of 4 questionnaire items- $-9,11,15$, and 16 . The mean score of 55 , shown in table 25 , was 74 percent of the possible weighted score of 75 .

Category VIII, Non-Factor Related Items, rünked fifth among the nine categories. Item 14, Keeping Abreast of Developments in Your Own Subject Matter Area, ranked first in the category with 7 strongly agreed and 6 agreed responses. Item 10, Planning Teaching Activities with Other Teachers or Administrators, ranked second in the category. Item 23 ranked third in the category with the highest number of agreed responses (9). Item 8 , Deciding What Teaching Technique Is Best for a Particular Intended Outcome, 
which ranked fourth in the category, and item 1, Diagnos ing Basic Learning Difficulties, which ranked sixth in the category, and item 4 , which ranked sixth in the category, all had 5 strongly agreed responses. Of the twelve items in this category there were 8 of the items with which no teacher strongly disagreed. They were items 14, Keeping Abreast of Developments in Your Own Subject Matter Area; item 23, Constructively Using Evaluation in Helping Student Progress; item 1, Diagnosing Basic Learning Difficulties; item 4, Identifying Student Attitudes in Order to Better Relate to Problems; item 19, Gearing Instruction to Problem Solving; item 17, Using Questioning Procedures That Promote Discussion; item 3, Identifying Student Disabilities That Need Referral or Special Remedial Work; and iten 41, Identifying the Gifted and Talented Students. Category VIII consisted of 12 questionnaire items-$1,3,4,8,10,14,17,18,19,23$, and 24 . The mean score of 55 , shown in table 25 , was 73 percent of the possible weighted score of 75 .

Category $V$, Discipline, ranked sixth among the nine categories. Item 26, Useful Methods of Classroom Discipline and When to Use Them, ranked first in the category with 2 strongly agreed and 10 agreed responses. Item 27, Maintaining Classroom Control without Appearing as an Ogre to the Students, ranked second in the category with 2 strongly agreed and 2 strongly disagreed responses. Category $V$ consisted of 2 questionnaire items-- 26 and 27. The mean score of 54 , shown in table 25 , was 73 percent of the possible weighted score of 75 .

Category I, Interpersonal Communication and Administration, 
ranked seventh among the nine categories. Item 29, Counseling and Conferring with Students, ranked first in the category with 4 strongly agreed and 6 agreed responses. Item 30, Involving 0thers in the School Program, ranked second in the category with 6 agreed and 3 strongly agreed responses. Both of the above had only one teacher who strongly disagreed with each item. Item 28, Communicating and Interacting with Parents, had the highest number of agreed responses ( 8 ). The item had 2 disagreed and 2 strongly disagreed responses each. Category I consisted of 4 questionnaire items-- $25,28,29$, and 30 . The mean score of 54 , shown in table 25, was 72 percent of the possible weighted score of 75 .

Category VI, Developing Personal Self, ranked eighth among the nine categories. Item 31, Developing a Personal Self-Evaluation Method, ranked first in the category with 3 strongly agreed and 7 agreed responses. Item 32, Developing a Broad Acceptance of Self, ranked second in the category with the highest number of strongly disagreed responses (4). Both of the above items had 3 undecided and disagreed responses. Item 34, Developing a Capacity of Accepting Others' Feelings, ranked last with 3 strongly agreed, 3 agreed, and 3 disagreed responses. Category VI consisted of 3 questionnaire items--31, 32, and 34 . The mean score of 52 , shown in table 25 , was 69 percent of the possible weighted score of 75 .

Category VII, Classroom Management, ranked ninth among the nine categories. Item 21, Providing. for Reinforcement, ranked first in the category with 3 strongly agreed and 3 agreed responses. Item 7, Teacher-Pupil Verbal Interaction, ranked second in the 
category with 6 agreed and one strongly agreed responses. Both of the above items had 4 undecided and one strongly disagreed response each. Items 22, Deciding on Appropriate Pupil Grouping Procedures for Instruction, and item 20, General Presentation of Inforamtion and Directions, had one strongly agreed response and 5 agreed responses each, while ranking fourth and fifth in the category. Category VII consisted of 4 questionnaire items--7, 20, 21 , and 22. The mean score of 46, shown in table 25, was 61 percent of the possible weighted score of 75 .

Ranked Categories of Secondary

Teachers with $11-15$ Years of

Experience

The description of the categories is presented in ranked order (table 26). Likewise, the description of the items within the categories is also presented in ranked order, according to the responses.

Category II, Developing Pupil Self, ranked first among the nine categories. Item 13, Motivating Students to Learn on Their Own, ranked first in the category with 7 strongly agreed and 3 agreed responses. Item 39, Instilling in the Student the will to Learn on His Own Initiative, ranked second in the category with 5 agreed and 6 strongly agreed responses. Both of the above items had one disagreed response each. Item 38, Stimulating Growth of Pupil Attitudes and Values, and item 37, Facilitating Development of Pupil Responsibility, ranking third and fourth had 4 agreed responses each. Item 36, Facilitating Pupil Social Interaction, ranked last in the category with 5 agreed and 5 disagreed responses each. No teacher strongly disagreed with any item in this 
TABLE 26

A SUMMARY OF RANKED CATEGORIES OF LAKE UNION CONFERENCE SECONDARY TEACHERS WHO HAVE TAUGHT $11-15$ YEARS

\begin{tabular}{llll}
\hline \multicolumn{1}{c}{ Categories } & $\begin{array}{c}\text { Ranking } \\
\text { Order }\end{array}$ & $\begin{array}{c}\text { Mean of } \\
\text { Weighted } \\
\text { Score }\end{array}$ & $\begin{array}{c}\text { Percentage } \\
\text { of Possible } \\
\text { Weighted } \\
\text { Score }\end{array}$ \\
\hline II Developing Pupil Self & 1 & 48 & 80 \\
III Individualized Instruction & 2 & 47 & 79 \\
IX Integration of Faith, Learning, and Practice & 3 & 47 & 78 \\
V Discipline & 4 & 44 & 73 \\
VI Developing Personal Self & 5 & 43 & 72 \\
I Interpersonal Communication and Administration & 6 & 43 & 71 \\
VIII Non-factor Related Items & 7 & 43 & 71 \\
IV Assessment & 8 & 40 & 60 \\
VII Classroom Management & 9 & 36 & 60
\end{tabular}

*Maximum weighted score for this table was 60 [five times the number of teachers in the group]. 
category. Category II consisted of 6 questionnaire items--13, 35, $36,37,38$, and 39 . The mean score of 48 , shown in table 26 , was 80 percent of the possible weighted score of 60 . (12 teachers $\times 5)$.

Category III, Individualized Instruction, ranked second among the nine categories. Item 15, Selecting and Developing Materials Activities Appropriate for Individualized Instruction, ranked first in the category with 6 strongly agreed and 5 agreed resfonses. Item 9, Developing the Use of the Computer in the Classroom, ranked second in the category with 5 strongly agree and 3 agreed and 3 undecided responses each. Item 11, Creating Useful Remedial Materials, ranked last with 3 agreed and disagreed responses each. Category III consisted of 4 questionnaire items--9, 11, 15, and 16 . The mean score of 47 , shown in table 26 , was 79 percent of the possible weighted score of 60 .

Category IX, Integration of Faith, Learning, and Practice, ranked third among the nine categories. Item 46, Making Bible Instruction More Applicable to Everyday Life, ranked first in the category with 7 strongly agreed and 2 agreed responses. I tem 44 , Constructing and Implementing a Christian Witness Program for Students and Teachers Together, ranked second in the category with 4 strongly agree and 7 agreed responses. Item 45, Transforming Faith into Action--by Vicarious Experience--Developing Christian Values and Attitudes, ranked third with 5 strongly agreed and 5 agreed responses. Both item 42, Developing a Better Understanding of the Theory of Integrating Faith, Learning and Practice and What Makes It Work, and item 43, Knowing How to Achieve Faith, Learning, and Practice from the Curriculum through Written Objectives 
and Evaluating Results, had 2 undecided and 2 disagreed responses. No teacher strongly disagreed with any of the items of this category. Category IX consisted of 5 questionnaire items--42, 43, 44,45 , and 46 . The mean score of 47 , shown in table 26 , was 78 percent of the possible weighted score of 60 .

Category V, Discipline, ranked fourth among the nine categories Item 26, Useful Methods of Classroom Discipline and When to Use Them, ranked first in the category with 3 strongly agreed and 6 agreed responses. Item 27, Maintaining Classroom Control without Appearing as an Ogre to the Students, ranked second in the category with 3 strongly agreed and 5 agreed responses. Both items of this category had no teacher who was undecided or who strongly disagreed with any item of this category. Category $V$ consisted of 2 questionnaire items- -26 and 27 . The mean score of 44 , shown in table 26, was 73 percent of the possible weighted score of 60 . Category VI, Developing Personal Self, ranked fifth among the nine categories. Item 31, Developing a Personal SelfEvaluation Method, ranked first in the category with 2 strongly agreed and 8 agreed responses. Item 32, Developing a Broad Acceptance of Self, ranked second in the category with 5 agreed and 3 strongly agreed responses. Item 34, Developing a Capacity of Accepting Others' Feelings, ranked last in the category. Category VI consisted of 3 questionnaire items-- 31, 32, and 33. The mean score of 43 , shown in table 26 , was 72 percent of the possible weighted score of 60 .

Category [, Interpersonal Communication and Administration, ranked sixth among the nine categories. Item 25, Knowing where to 
Refer Student Problems beyond What Can Be Handled by the Teacher, ranked first in the category with 2 strongly agreed and 7 agreed responses. Item 30, Involving Others in the School Program, ranked second in the category with 9 agreed, 0 strongly agreed, and 0 strongly disagreed responses. Neither item 29, Counseling and Conferring with Students, nor item 28, Communicating and Interacting with Parents, had any teacher who was undecided with the items. No teacher strongly disagreed with any item in this category. Category I consisted of 4 questionnaire items-- 25, 28, 29, and 30 . The mean score of 43 , shown in table 26 , was 71 percent of the possible weighted score of 60 .

Category VIII, Non-Factor Related Items, ranked seventh among the nine categories. Item 14, Keeping Abreast of Developments in Your Own Subject Matter Area, ranked first in the category with 6 strongly agreed and 4 agreed responses. Item 4 , Identifying Student Attitudes in Order to Better Relate to Problems, ranked second in the category with 5 strongly agreed, 3 agreed, and 3 undecided responses. Item 19, Gearing instruction to Problem Solving, ranked fifth in the category with the highest number of agreed responses (10). Item 18. Utilization of Audiovisual Equipment and Other Mechanical Aids, and item 41, Identifying the Gifted and Talented Students, which ranked tenth and eleventh in the category had the same number of strongly agreed (0), agreed (6), undecided (2), disagreed (3), and strongly disagreed (1) responses. Category VIII consisted of 12 questionnaire items--1, $3,4,8,10,14,17,18,19,23,24$, and 41 . The mean score of 
43, shown in table 26 , was 71 percent of the possible weighted score of 60 .

Category IV, Assessment, ranked eighth among the nine categories. Item 33, Selecting and Specifying Performance Goals and Objectives, ranked first in the category with 0 strongly agreed, 9 agreed, and 0 strongly disagreed responses. Item 40, Developing or Modifying Instructional Procedures to Suit Your Own Strengths, ranked second in the category with highest humber of strongly agreed responses (4). Item 6 , Involving Students in Self-Evaluation, which ranked third, had 0 teachers who strongly agree or strongly disagreed with this item. Item 2, Constructing and Using Tests for Evaluating Academic Progress, ranked third with one teacher who strongly agreed and one teacher who strongly disagreed. Category IV consisted of 6 questionnaire items--2, 5, 6, 12,33, and 40. The mean score of 40 , shown in table 26 , was 66 percent of the possible weighted score of 60 .

Category VII, Classroom Management, ranked ninth among the nine categories. Item 7 , Teacher-Pupil Yerbal interaction, ranked first in the category with 1 strongly agreed and 6 agreed responses. Item 22, Deciding on Appropriate Pupil Grouping Procedures for Instruction, ranked second in the category with 6 agreed responses. No teacher strongly agreed or strongly disagreed with this item. The above 2 items had six teachers who agreed, four teachers who disagreed, and no teachers who strongly disagreed. Item 20, General Presentation of Information and Directions, ranked last with one teacher who strongly disagreed and one teacher who strongly agreed with this item. Category VII consisted of 4 questionnaire items--7, 20, 21, and 22. The mean 
score of 36 , shown in table 26 , was 60 percent of the possible weighted score of 60 .

Ranked Categories of Secondary

Teachers with 16-20 Years of

Experience

The description of the categories is presented in ranked order (table 27). Likewise, the description of the items within the categories is also presented in ranked order, according to the responses.

Category VIII, Non-Factor Related Items, ranked first among the nine categories. Item 4, Identifying Student Attitudes in Order to Better Relate to Problems, ranked first in the category with 4 strongly agreed and 4 agreed responses. Item 8, Deciding What Teaching Technique Is Best for a Particular Intended Outcome, ranked second in the category with 4 strongly agreed and 3 agreed responses. Item 3, Identifying Student Disabilities that Need Referral or Special Remedial Work, also had 4 strongly agreed responses. Item 14, Keeping Abreast of Developments in Your Own Subject Matter Area, ranked fourth and had the highest number of strongly agreed responses (5). Item 19, Gearing Instruction to Problem Solving, ranked seventh in the category and had the highest agreed responses (6). Item 10, Planning Teaching Activities with Other Teachers or Administrators, item 18, Utilization of Audiovisual Equipment and Other Mechanical Aids, and item 41, Identifying the Gifted and Talented Students, which were the last 3 items of the category, all had 3 strongly disagreed responses and 0 disagreed responses each. Category VIII consisted of 12 questionnaire items-- 
TABLE 27

A SUMMARY OF RANKED CATEGORIES OF LAKE UNION CONFERENCE SECONDARY TEACHERS WHO HAD TAUGHT 16-20 YEARS

\begin{tabular}{|c|c|c|c|c|}
\hline & Categories & $\begin{array}{l}\text { Ranking } \\
\text { Order }\end{array}$ & $\begin{array}{l}\text { Mean of } \\
\text { Weighted } \\
\text { Score* }^{\star}\end{array}$ & $\begin{array}{c}\text { Percentage } \\
\text { of Possible } \\
\text { Weighted } \\
\text { Score }\end{array}$ \\
\hline VIII & Non-factor Related I tems & 1 & 29 & 72 \\
\hline IX & Integration of Faith, Learning, and Practice & 2 & 29 & 72 \\
\hline$v$ & Discipline & 3 & 29 & 71 \\
\hline II & Developing Pupil Self & 4 & 28 & 71 \\
\hline I I I & Individualized Instruction & 5 & 27 & 68 \\
\hline IV & Assessment & 6 & 25 & 62 \\
\hline VI & Developing Personal Self & 7 & 24 & 61 \\
\hline I & Interpersonal Communication and Administration & 8 & 24 & 59 \\
\hline VII & Classroom Management & 9 & 23 & 58 \\
\hline
\end{tabular}

*Maximum weighted score for this table was 40 [five times the number of teachers in the group]. 
$1,3,4,8,10,14,17,18,19,23,24$, and 41 . The mean score of 29 , shown in table 27 , was 72 percent of the possibie weighted score of 40 ( 8 teachers $\times 5)$.

Category IX, integration of Faith, Learning, and Practice, ranked second among the nine categories. Item 42, Developing a. Better Understanding of the Theory of Integrating Faith, Learning, and Practice and what Makes It Work, ranked first in the category with 3 strongly agreed, 3 agreed, 1 undecided, 1 strongly disagreed, and 0 disagreed responses. Item 46, Making Bible Instruction More Applicable to Everyday Life, ranked second in the category with the same number of responses as item 42 which ranked first in the category. Item 45, Transforming Faith into Action--by Vicatious Experience--Developing Christian Values and Attitudes, ranked third in the category. Item 44 , Constructing and Implementing a Christian Witness Program for Students and Teachers Together, ranked fourth with 2 strongly agreed and 2 strongly disagreed responses each. Iteri 43, knowing How to Achieve Faith, Learning and Practice from the Curriculum through Written Objectives and Evaluating Results, ranked last in the category with 3 strongly agreed and 3 strongly disagreed responses each. No teacher disagreed with any item in this category. Category IX consisted of 5 questionnaire items- $-42,43,44,45$, and 46 . The mean score of 29, shown in table 27 , was 72 percent of the possible weighted score of 40 .

Category V, Discipline, ranked third among the nine categories. Item 26, Useful Methods of Classroom Discipline and When to Use Them, ranked first in the category with 3 strongly agreed and 3 agreed 
responses. Item 27, Maintaining Classroom Control without Appearing as an Ogre to the Students, ranked second in the category with 4 strongly agreed and 1 agreed response. Both of the above items had two teachers who strongly disagreed with the items of the category. Category $v$ consisted of 2 questionnaire items-- 26 and 27. The mean score of 29 , shown in table 27 , was 71 percent of the possible weighted score of 40 .

Category II, Developing Pupil Self, ranked fourth among the nine categories. Item 13, Motivating Students to Learn on Their Own, ranked first in the category with 5 strongly agreed and 2 agreed responses. Item 39, Instilling in the Student the Will to Learn on His Own Initiative, ranked second in the category with 4 agreed, 1 agreed, and 1 undecided responses. Item 38, Stimulating Growth of Pupil Attitudes and Values, ranked third in the category with the highest number of agreed responses (7). Item 35, facilitating Pupil Self-Concept and Worth, and item 37, Facilitating Development of Pupil Responsibility, each had 2 strongly agreed, 3 agreed, and 1 undecided responses. These two items ranked fourth and fifth in the category. Item 36, Facilitating Pupil Social Interaction, ranked last in the category. Category II consisted of 6 questionnaire items- $-13,35,36,37,38$, and 39 . The mean score of 28 , shown in table 27 , was 71 percent of the possible weighted score of 40 .

Category III, Individualized Instruction, ranked fifth among the nine categories. Item 11, Creating Useful Remedial Materials, ranked first in the category with 2 strongly agreed and 4 agreed responses. Item 9, Developing the Use of the Computer in the 
Classroom, ranked second in the category with 4 strongly agreed, 2 agreed, 0 undecided, and a total of 2 disagreed and strongly disagreed responses. Items 15, Selecting and Developing Materials Activities Appropriate for Individualized Instruction, and item 16 , Implementing and Supervising Individualized Instruction, ranked third and fourth having 0 strongly agree and 2 strongly disagreed responses each. Item 16 also had 3 agreed and 3 undecided responses each. Category III consisted of 4 questionnaire items-$9,11,15$, and 16 . The mean score of 27 , shown in table 27 , was 68 percent of the possible weighted score of 40 .

Category IV, Assessment, ranked sixth among the nine categories. Item 2, Constructing and Using Tests for Evaluating Academic Progress, ranked first in the category with 3 strongly agreed and 3 agreed responses. Item 6 , Involving Students in Self-Evaluation, ranked second in the category with the highest number of agreed responses (5). Item 6, item 40, Developing or Modifying Instructional Procedures to Suit Your Own Strengths, item 12, Evaluating Instruction/Instructional Design, and item 5, Establishing Appropriate Performance Standards, all had I strongly agreed response and 2 strongly disagreed responses. Item 33, Selecting and Specifying Performance Goals and Objectives, ranked last with the highest number of strongly disagreed responses (3). Category IV consisted of 6 questionnaire items--2, 5, 6, 12, 33, and 40 . The mean score of 25, shown in table 27 , was 62 percent of the possible weighted score of 40 .

Category VI, Developing Personal Self, ranked seventh among the nine categories. Item 31, Developing a Personal Self- 
Evaluation Method, ranked first in the category with 3 strongly agreed and 3 strongly disagreed responses. Item 32, Developing a Broad Acceptance of Self, ranked second in the category with 1 strongly agreed, 3 agreed, 1 undecided, 1 disagreed, and 2 strongly disagreed responses. Item 34, Developing a Capacity of Accepting Others' Feelings, ranked third and last with the same number of responses as item 32, which ranked second in the category. Category VI consisted of 3 questionnaire items-- 31, 32, and 34 . The mean score of 24 , shown in table 27 , was 61 percent of the possible weighted score of 40 .

Category I, Interpersonal Communication and Administration, ranked eighth among the nine categories. Item 29, Counsel ing and Conferring with Students, ranked first in the category with 2 strongly agreed, 4 agreed, and 7 strongly disagreed responses. Item 25, Knowing Where to Refer Student Problems beyond What Can Be Handled by the Teacher, ranked second in the category with 2 agreed and 2 strongly agreed responses. Item 28, Communicating and Interacting with Parents, ranked third with 1 agreed, 1 undecided, and 1 disagreed response. Item 30, Involving Others in the School Program, ranked last with 3 agreed and 3 strongly disagreed responses. Category I consisted of 4 questionnaire items-$25,28,29$, and 30 . The mean score of 24 , shown in table 27 , was 59 percent of the possible weighted score of 40 .

Category VII, Classroom Management, ranked ninth among the nine categories. Item 7, Teacher-Pupil Verbal interaction, ranked first in the category with 3 strongly agreed and 2 agreed responses. Item 21, Providing for Reinforcement, ranked second in the category 
with 2 agreed, I strongly agreed, and the highest number of undecided responses (3). Item 22, Deciding on Appropriate Pupil Grouping Procedures for Instruction, ranked third in the category with 3 strongly disagreed and a total of 3 agreed and strongly disagreed responses. Item 20, General Presentation of Information and Directions, ranked last with 0 strongly agreed and the highest number of strongly disagreed (4) responses. Category VII consisted of 4 questionnaire items--7,20,21, and 22. The mean score of 23 , shown in table 27 , was 58 percent of the possible weighted score of 40 .

Ranked Categories of Secondary

Teachers with $27+$ Years of

Experience

The description of the categories is presented in ranked order (table 28). Likewise, the description of the items within the catcgorics is also presented in ranked order, according to the responses.

Category IX, Integration of Faith, Learning, and Practice, ranked first among the nine categories. Item 44, Constructing and Implementing a Christian Witness Program for Students and Teachers Together, ranked first in the category with 5 strongly agreed and 4 agreed responses. Item 46, Making Bible Instruction More Applicable to Everyday Life, ranked second in the category with the same number of strongly agreed (5), agreed (4), undecided (0), disagreed $(0)$, strongly disagreed $(0)$ responses. Item 45, Transforming Faith into Action--By Vicarious Experience--Developing Christian Values and Attitudes, ranked third and no teacher undecided, disagreed, or strongly disagreed with the item. No 
TABLE 28

A SUMMARY OF RANKED CATEGORIES OF LAKE UNION CONFERENCE SECONDARY TEACHERS WHO HAD TAUGHT 21+ YEARS

\begin{tabular}{llll}
\hline \multicolumn{1}{c}{ Categories } & $\begin{array}{c}\text { Ranking } \\
\text { Order }\end{array}$ & $\begin{array}{c}\text { Mean of } \\
\text { Weighted } \\
\text { Score }\end{array}$ & $\begin{array}{c}\text { Percentage } \\
\text { of Possible } \\
\text { Weighted } \\
\text { Score }\end{array}$ \\
\hline IX Integration of Faith, Learning, and Practice & 1 & 39 & 86 \\
V Discipline & 2 & 36 & 79 \\
II Developing Pupil Self & 3 & 35 & 78 \\
VIII Non-factor Related Items & 4 & 32 & 72 \\
III Individualized Instruction & 5 & 32 & 71 \\
IV Assessment & 6 & 32 & 70 \\
VI Developing Personal Self & 7 & 30 & 67 \\
I Interpersonal Communication and Administration & 8 & 29 & 64 \\
VII Classroom Management & 9 & 27 & 59 \\
\hline
\end{tabular}

in the group]. 
teacher strongly disagreed with any item of the category. Category IX consisted of 5 questionnaire items-- $42,43,44,45$, and 46 . The mean score of 39 , shown in table 28 , was 86 percent of the possible weighted score of 45 (9 teachers $\times 5$ ).

Category $V$, Discipline, ranked second among the nine categories. Item 26, Useful Methods of Classroom Discipline and When to Use Them, ranked first in the category with 2 strongly agreed and 6 agreed responses. Item 27, Maintaining Classroom Control without Appearing as an Ogre to the Students, ranked second in the category with 4 agreed and 2 strongly disagreed. No teacher strongly disagreed with either item of the category. Category $V$ consisted of 2 questionnaire items--26 and 27 . The mean score of 36 , shown in table 28, was 79 percent of the possible weighted score of 45 . Category II, Developing Pupil Self, ranked third among the nine categories. Item 13, Motivating Students to Learn on Their Own, ranked first in the category with 4 strongly agreed and 5 agreed responses. Item 38, Stimulating Growth of Pupil Attitudes and Values, ranked second in the category with 9 agreed responses. No teacher strongly agreed, was undecided, disagreed or strongly disagreed with this item. Item 35, Facilitating Pupil Self-Concept and Worth, and item 36, Facilitating Pupil Social Interaction, had 5 agreed responses and 3 undecided responses each. No teacher strongly disagreed with any item of this category. Category II consited of 6 questionnaire items-- 13,35, 36,37, 38, and 39. The mean score of 35 , shown in table 28 , was 78 percent of the possible weighted score of 45 .

Category VIII, Non-Factor Related Items, ranked fourth among 
the nine categories. Item 14, Keeping Abreast of Development in Your Own Subject Matter Area, ranked first in the category with 4 strongly agreed and 4 agreed responses. Item 19, Gearing Instruction to Problem Solving, ranked second in the category with 3 strongly agreed and 5 agreed responses. Item 1, Diagnosing Basic Learning Difficulties, ranked third in the category with 1 strongly agreed, 1 disagreed, 0 undecided, and 0 strongly agreed responses. Item 17 ranked fourth in the category and had the same number of strongly agreed (1), undecided (0), disagreed (1), and strongly disagreed (0) responses. Item 24 ranked last in the category with 0 strongly agreed and 0 agreed responses. Category VIII consisted of 12 questionnaire items--1, 3, 4, 8, 10, 14, 17. 18, 19, 23, 24, and 41 . The mean score of 32 , shown in table 28 , was 72 percent of the possible weighted score of 45 .

Category III, Individualized Instruction ranked fifth among the nine categories. Item 9, Developing the Use of the Computer in the Classroom, ranked first inthe category with 2 strongly agreed and 6 agreed responses. item 15, Selecting and Developing Materials Activities Appropriate for Individualized Instruction, ranked second in the category with 4 agreed and 1 strongly agreed response. Item 16, Implementing and Supervising Individualized Instruction, ranked third with 3 agreed and 3 undecided responses. No teacher strongly disagreed with any of the above three items. Item 11, Creating Useful Remedial Materials, ranked last in the category. Category III consisted of 4 questionnaire items--9, 11 , 15, and 16 . The mean score of 32 , shown in table 28 , was 71 percent of the possible weighted score of 45 . 
Category IV, Assessment, ranked sixth among the nine categories. Item 6, Involving Students in Self-Evaluation, ranked first in the category with 1 strongly agreed and 6 agreed responses. Item 40, Developing or Modifying Instructional Procedures to Suit Your Own Strengths, ranked second in the category. Item 5, Establishing Appropriate Performance Standards, ranked third in the category with 2 strongly agree, 2 undecided, and 2 disagree responses. Item 2, Constructing and Using Tests for Evaluating Academic Progress, ranked last in the category with 4 agree, 4 disagree, 1 undecided, 0 strongly agree, and 0 strongly disagree responses. No teacher strongly disagreed with any item of this category. Category IV consisted of 6 questionnaire items--2, 3, 6, 12, 33, and 40 . The mean score of 32 , shown in table 28 , was 70 percent of the possible weighted score of 45 .

Category VI, Developing Personal Self, ranked seventh among the nine categories. Item 31, Developing a Personal Self-Evaluation Method, ranked first in the category with 1 strongly agreed and 4 agreed responses. Item 34, Developing a Capacity of Accepting Others' Feelings, ranked second in the category with the same number of strongly agreed responses (1) and agreed responses (4) as item 31 which ranked first in the category. Both of the above items had 2 undecided responses each. Item 32, Developing a Broad Acceptance of Self, ranked last in the category with 3 agreed and 3 undecided responses each. Category VI consisted of 3 questionnaire items--31, 32, and 34. The mean score of 30 , shown in table 28 , was 67 percent of the possible weighted score of 45 . Category I, Interpersonal Communication and Administration, 
ranked eighth among the nine categories. Item 29, Counseling and Conferring with Students, ranked first in the category with 1 strongly agreed and 4 agreed responses. Item 28, Communicating and Interacting with Parents, ranked second in the category with the same number of strongly agreed (i) and agreed (4) responses as item 29 which ranked first in the category. Item 25, Knowing Where to Refer Student Problems beyond What Can Be Handled by the Teacher, ranked third in the category with 3 agreed, undecided, and disagreed responses each. Item 30, Involving Others in the School Program, ranked last in the category with 2 agreed, 2 disagreed, and 5 undecided responses. No teacher strongly disagreed with any item of this category. Category I consisted of 4 questionnaire items-$25,28,29$, and 30 . The mean score of 29 , shown in table 28 , was 64 percent of the possible weighted score of 45 . Category VII, Classroom Management, ranked ninth among the nine categories. Item 21, Providing for Reinforcement, ranked first in the category with 2 strongly agreed, 2 agreed, and 2 strongly disagreed responses. Item 20, General Presentation of Information and Directions, ranked second in the category with 2 strongly agreed, 1 agreed, and 2 undecided responses. Item 7, TeacherPupil Verbal Interaction, ranked last in the category with 3 agreed and 3 disagreed responses. For this category there were as many strongly disagreed as strongly agreed responses. Category VII consisted of 4 questionnaire items--7,20,21, and 22 . The mean score of 27 , shown in table 28 , was 59 percent of the possible weighted score of 45 . 
Summary of Secondary Teachers by

Years of Experience

Research questions 13 (What are the perceived inservice needs of Lake Union Conference secondary teachers who have taught 0-5 years?), 14 (What are the perceived inservice needs of Lake Union Conference secondary teachers who have taught 6-10 years?), 15 (What are the perceived inservice needs of Lake Union Conference secondary teachers who have taught $11-15$ years?), 16 (What are the perceived inservice needs of Lake Union Conference secondary teachers who nave taught 16-20 years?), and 17 (What are the perceived inservice needs of Lake Union Conference secondary teachers who have taught $21+$ years?), as posed in chapter 111, are addressed in the presentation of the responses of five groups: secondary teachers who had taught $0-5$ years, $6-10$ years, $11-15$ years, 16-20 years, and $21+$ years. In addition, the above responses were compared to all the secondary teachers of the Lake Union Conference (fig. 6, and table 29).

Category IX, Integration of Faith, Learning, and Practice was identified as the first perceived inservice need by the secondary teachers who had taught $0-5,6-10$, and $21+$ years. The category was perceived as the second inservice need by the secondary teachers who had taught $16-20$ years and as the third inservice need by the secondary teachers who had taught 11-15 years, whereas the category was ranked first by all secondary teachers as a group. Category II, Developing Pupil Self, was perceived as the first inservice need for the secondary teachers who had taught 11-15 years. Category VIII, Non-Factor Related Items, was ranked first by the secondary teachers 


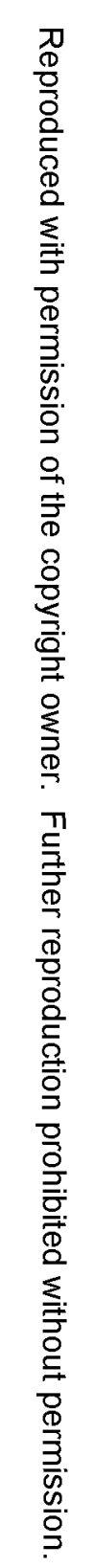

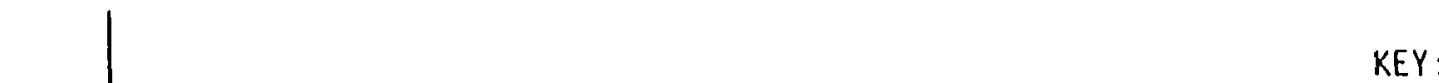

$\square$ All Sec.

Q $0-5$

$\begin{array}{ll} & \square 6-10 \\ & \square 11-15 \\ & \square 16-20\end{array}$

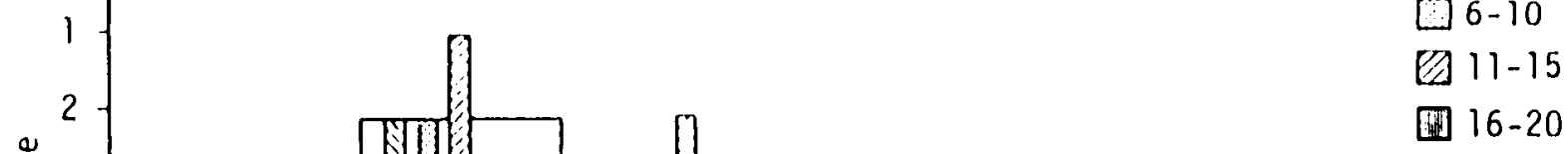

岕 $3-$ N

高 4

点 5

0

宸 6

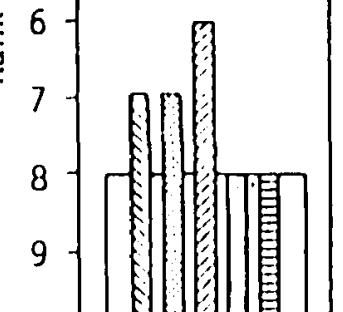

I

II

III

IV

$\mathrm{V}$

Fig. 6. Comparison of the ranked categories of who had taught $0-5,6-10,11-15,16-20$, and $21+$ years. 
TABLE 29

A COMPARISON OF RANKED CATEGORIES OF ALL SECONDARY AND

SECONDARY TEACHERS WHO HAD TAUGHT 0-5, 6-10, 11-15, $16-20$, AND $21+$ YEARS

\begin{tabular}{lccccccccc}
\hline \hline Years of Experience & I & II & III & IV & V & VI & VII & VIII & IX \\
\hline A11 Secondary & 8 & 2 & 4 & 7 & 3 & 6 & 9 & 5 & 1 \\
$0-5$ & 7 & 2 & 6 & 8 & 4 & 3 & 9 & 5 & 1 \\
$6-10$ & 7 & 2 & 4 & 3 & 6 & 8 & 9 & 5 & 1 \\
$11-15$ & 6 & 1 & 2 & 8 & 4 & 5 & 9 & 7 & 3 \\
$16-20$ & 8 & 4 & 5 & 6 & 3 & 7 & 9 & 1 & 2 \\
$21+$ & 8 & 3 & 5 & 6 & 2 & 7 & 9 & 4 & 1 \\
\hline
\end{tabular}

who had taught 16-20 years; likewise, Category II, Developing Pupil Self, was identified as the second perceived inservice need for the secondary teachers who had taught $0-5$ years and $6-10$ years; : hereas the category was ranked second by all secondary teachers and had other rankings for the secondary teachers who had taught $11-16$, $16-20$, and $21+$.

The remaining categories varied in rankings except category VIi. Classroom Management, which was ranked last by all five groups and all the secondary teachers.

\section{Combination of Teaching Assignments}

Ranked Categories of Elementary Teachers Who Had Taught Three or Fewer Grades

The description of the categories is presented in ranked order (table 30). Likewise, the description of the items within the categories is also presented in ranked order, according to the responses. 
TABLE 30

A SUMMARY OF RANKED CATEGORIES OF LAKE UNION CONFERENCE ELEMENTARY TEACHERS WHO TEACH THREE OR LESS GRADES

\begin{tabular}{|c|c|c|c|c|}
\hline & Categories & $\begin{array}{l}\text { Ranking } \\
\text { Order }\end{array}$ & $\begin{array}{l}\text { Mean of } \\
\text { Weighted } \\
\text { Score }\end{array}$ & $\begin{array}{c}\text { Percentage } \\
\text { of Possible } \\
\text { Weighted } \\
\text { Score }\end{array}$ \\
\hline II & Developing Pupil Self & 1 & 379 & 79 \\
\hline III & Individualized Instruction & 2 & 374 & 77 \\
\hline IX & Integration of Faith, Learning, and Practice & 3 & 372 & 77 \\
\hline v & Discipline & 4 & 351 & 73 \\
\hline I & Interpersonal Communication and Administration & 5 & 339 & 71 \\
\hline VIII & Non-factor Related Items & 6 & 338 & 70 \\
\hline VI & Developing Personal Self & 7 & 327 & 68 \\
\hline IV & Assessment & 8 & 323 & 67 \\
\hline VII & Classroom Management & 9 & 299 & 62 \\
\hline
\end{tabular}


Category II, Developing Pupil Self, ranked first among the nine categories. Item 13, Motivating Students to Learn on The ir Own, ranked first in tine category with 46 strongly agreed and 43 agreed responses. Item 39, Instilling in the Student the will to Learn on His Own Initiatve, ranked second in the category. Item 35, Facilitating Pupil Self-Concept and Worth, ranked fourth in the category with the highest number of agreed responses (50). I tem 36, Facilitating Pupil Social Interaction, ranked last in the category with the highest number of disagreed (17) and undecided responses (20). Category II consisted of 6 questionnaire items-$13,35,36,37,38$, and 39 . The mean score of 379 , shown in table 30 , was 79 percent of the possible weighted score of 480 (96 teachers $\times 5$ ). Categorj III, Individualized Instruction, ranked second among the nine categories. Item 9, Developing the Use of the Computer in the Classroom, ranked first in the category with 40 strongly agreed and 26 agreed responses. Item 11 , Creating Useful Remedial Materials, ranked second in the category with 43 agreed and 28 strongly agreed responses. Item 11 also had the same number of undecided and disagreed responses (12). Item 16, Implementing and Supervising Individualized Instruction had the highest number of agreed responses (57). Category III consisted of 4 questionnaire items, 9, 11, 15, and 16 . The mean score of 374 , shown in table 30 , was 78 percent of the possible weighted score of 480 .

Category IX, Integration of Faith, Learning, and Practice, ranked third among the nine categories. Item 46 , Making Bible Instruction More Applicable to Everyday Life, ranked forst in the category with 45 strongly agreed and 37 agreed responses. Item 45 , 
Transforming Faith into Action--by Vicarious Experience--Developing Christian Values and Attitudes, ranked second in the category with the highest number of agreed responses (45). Both of the above items had only one teacher who strongly disagreed with each item. Item 44, Constructing and Implementing a Christian Witness Program for Students and Teachers Together, ranked third. Item 42, Developing a Better Understanding of the Theory of Integrating Faith, Learning and Practice and What Makes It 'Nork, ranked fourth, and item 43, Knowing How to Achieve Faith, Learning, and Practice from the Curriculum through Written Objectives and Evaluating Results, ranked fifth in the category with the highest number of undecided, disagreed, and strongly disagreed responses. Category IX consisted of 5 questionnaire items $-42,43,44,45$, and 46 . The mean score of 372 , shown in table 30, was 77 percent of the possible weighted score of 480 . Category V, Discipline, ranked fourth among the nine categories Item 26, Useful Methods of Classroom Discipline and When to Use Them, ranked first in the category with 27 strongly agreed and 38 agreed responses. Item 27, Maintaining Classroom Control without Appearing as an Ogre to the Students, ranked second in the category with the highest number of strongly agreed (28), undecided (14), and strongly disagreed responses (5). Category $y$ consisted of 2 questionnaire items--26 and 27. The mean score of 351, shown in table 30 , was 73 percent of the possible weighted score of 480 .

Category I, Interpersonal Communication and Administration, ranked fifth among the nine categories. Item 30 , Involving Others in the School Program, ranked first in the category with 11 strongly agreed and 55 agreed responses. Item 29 , Counseling and Con- 
ferring with Students, ranked second in the category. Both of the above items had 2 strongly disagreed responses each. Item 25, Knowing Where to Refer Student Problems beyond What Can Be Handled by the Teacher, had the highest number of strongly agreed responses (19) and disagreed responses (28). Category I consisted of 4 questionnaire items--25, 28, 29, and 30. The mean score of 339 , shown in table 30 , was 71 percent of the possible weighted score of 480 .

Category VIII, Non-Factor Related Items, ranked sixth among the nine categories. Item 1, Diagnosing Basic Learning Difficulties. ranked first in the category with 28 strongly agreed and 47 agreed responses. Item 3, Identifying Student Disabilities that Need Referral or Special Remedial Work, ranked second in the category with the lowest number of undecided responses (9). Both items 23, Constructively Using Evaluation in Helping Student Progress, and item 19, Gearing Instruction to Problem Solving, had 13 strongly agreed responses. Item 19 and item 4, Identifying Student Attitudes in Order to Better Relate to Problems, had 48 agreed responses. Three items, 41 , Identifying the Gifted and Talented Students, 17 , Jsing Questioning Procedures that Promote Discussion, and i3, Utilization of Audiovisual Equipment and Other Mechanical Aids, all had the same number of strongly agreed (9) and agreed (41) responses. Category VIII consisted of 12 questionnaire items--1,3, $4,8,10,14,17,18,19,23,24$, and 41 . The mean score of 338 , shown in table 30 , was 70 percent of the possible weighted score of 480 .

Category VI, Developing Personal Self, ranked seventh among 
the nine categories. Item 31, Developing a Personal Self-Evaluation Method, ranked first in the category with 15 strongly agreed and 43 agreed responses which was the highest for the category. Item 32 , Developing a Broad Acceptance of Self, ranked second in the category with the highest number of strongly agreed responses (17). Item 34, Developing a Capacity of Accepting Others' Feelings, ranked last with the highest number of strongly disagreed (7) and disagreed (22) responses. Category VI consisted of 3 questionnaire items--31, 32, and 34 . The mean score of 327 , shown in table 30 , was 68 percent of the possible weighted score of 480 .

Category IV, Assessment, ranked eighth among the nine categories. Item 40, Developing or Modifying Instructional Procedures to Suit Your Own Strengths, ranked first in the category with 13 strongly agreed and 43 agreed responses. Item 12, Evaluating Instruction/Instructional Design, ranked second in the category with the highest undecided responses (20) and 0 strongly disagreed responses. Item 5, Establishing Appropriate Performance Standards, ranked third in the category. Item 2, Constructing and Using Tests for Evaluating Academic Progress, ranked last in the category with the highest disagreed (28) and strongly disagreed (5) responses. Category IV consisted of 6 questionnaire items--2, 5, 6, 12, 33, and 40 . The mean score of 323, shown in table 30, was 67 percent of the possible weighted score of 480 .

Category VII, Classroom Management, ranked ninth among the nine categories. Item 21, Providing for Reinforcement, ranked first in the category with 9 strongly agreed and 29 agreed responses. Item 22, Deciding on Appropriate Pupil Grouping Procedures for 
Instruction, ranked second in the category with the highest number of strongly agreed (12) and agreed (42) responses. Both of the above items had 20 undecided and 3 strongly agreed responses. Both item 7, Teacher-Pupil Verbal Interaction, and item 20, General Presentation of Information and Directions, which ranked third and fourth in the category had 7 strongly disagreed responses. Category VII consisted of 4 questionnaire items--7,20, 21, and 22 . The mean score of 299, shown in table 30, was 62 percent of the possible weighted score of 480 .

Ranked Categories of Elementary Teachers Who Had Taught More than Three Grades

The description of the categories is presented in ranked order (table 31). Likewise, the description of the items within the categories is also presented in ranked order, according to the responses.

Category IX, Integration of Faith, Learning, and Practice, ranked first among the nine categories. Item 46, Making Bible Instruction More Applicable to Everyday Life, ranked first in the category with 29 strongly agreed and 17 agreed resporises. Item 44 , Constructing and Implementing a Christian Witness Program for Students and Teachers Together, ranked second in the category with the highest number of agreed resporises (27). Both item 45, Transforming Faith into Action--By Vicarious Experience--Developing Christian values and Attitudes, which ranked third, and item 43, Knowing How to Achieve Faith, Learning, and Practice from the Curriculum through Written Objectives and Evaluating Results, which 
TABLE 31

A SUMMARY OF RANKED CATEGORIES OF LAKE UNION CONFERENCE ELEMENTARY TEACHERS WHO TEACH MORE THAN THREE GRADES

\begin{tabular}{llcc}
\hline \multicolumn{1}{c}{ Categories } & $\begin{array}{c}\text { Mean of } \\
\text { Ranking } \\
\text { Order }\end{array}$ & $\begin{array}{c}\text { Percentage } \\
\text { of } \begin{array}{c}\text { Possible } \\
\text { Weighted } \\
\text { Score* }\end{array}\end{array}$ & $\begin{array}{c}\text { Score } \\
\text { IX Integration of Faith, Learning, and Practice }\end{array}$ \\
II Developing Pupil Self & 1 & 230 & 81 \\
V Discipline & 2 & 212 & 74 \\
III Individualized Instruction & 3 & 203 & 71 \\
I Interpersonal Communication and Administration & 5 & 202 & 71 \\
VIII Non-factor Related Items & 6 & 201 & 70 \\
VI Developing Personal Self & 6 & 197 & 69 \\
IV Assessment & 7 & 187 & 66 \\
VII Classroom Management & 8 & 185 & 65 \\
\hline
\end{tabular}
in the group]. 
ranked last in the category had 24 agreed responses. Both item 42 , Developing a Better Understanding of the Theory of Integrating Faith, Learning, and Practice and What Makes It Work, and item 43, Knowing How to Achieve Faith, Learning, and Practice from the Curriculum through Written Objectives and Evaluating Results, had the highest number of undecided responses (10) each. Category IX consisted of 5 questionnaire items-- $42,43,44,45$, and 46 . The mean score of 230 , shown in table 31 , was 81 percent of the possible weighted score of $285(57$ teachers $\times 5)$.

Category II, Developing Pupil Self, ranked second among the nine categories. Item 39, Instilling in the Student the will to Learn on His Own Initiative, ranked first in the category with 22 strongly agreed and 25 agreed responses. Item 13, Motiving Students to Learn on Their Own, ranked second in the category. Both of the above items had 25 agreed and 2 strongly disagreed responses. Item 35, Facilitating Pupil Self-Concept and worth, had the highest number of agreed responses (34) and ranked third in the category. Item 36, Facilitating Pupil Social Interaction, ranked last in the category with 30 agreed, and the highest number of undecided (io) and disagreed (10) responses. Category II consisted of 6 questionnaire items- $-13,35,36,37,38$, and 39 . The mean score of 212 , shown in table 31 , was 74 percent of the possible weighted score of 285 .

Category $V$, Discipline, ranked third among the nine categories. Item 26, Useful Methods of Classroom Discipline and When to Use Them, ranked first in the category with 13 strongly agreed and 25 agreed responses. Item 27, Maintaining Classroom Control without 
Appearing as an Ogre to the Students, ranked second in the category. Both items had two teachers who strongly disagreed with each item. Category $V$ consisted of 2 questionnaire items--26 and 27 . The mean score of 203, shown in table 31, was 71 percent of the possible weighted score of 285 .

Category III, Individualized Instruction, ranked fourth among the nine categories. Item 11, Creating Useful Remedial Materials, ranked first in the category with 25 strongly agreed and 13 agreed responses. Item 9, Developing the Use of the Computer in the Classroom, ranked second in the category with 16 agreed and 16 strongly agreed responses. Item 9 had the highest number of undecided responses (15) of the category. Both item 15 (Selecting and Developing Materials Activities Appropriate for Individualized Instruction, and item 16, Implementing and Supervising Individualized instruction, had 15 disagree responses. Category III consisted of 4 questionnaire items--9, 11, 15, and 16. The mean score of 202, shown in table 31 , was 71 percent of the possible weighted score of 285 .

Category I, Interpersonal Communication and Administration ranked fifth among the nine categories. Item 28, Communicating and Interacting with Parents, ranked first in the category with 12 strongly agreed and 27 agreed responses. Item 25, Knowing where to Refer Student Problems beyond What Can Be Handled by the Teacher, ranked second in the category with the highest number of strongly agreed responses (14). Item 29, Counseling and Conferring with Students, ranked last in the category with the highest number of agreed (28) 
and disagreed (12) responses. Category I consisted of 4 questionnaire items- $-25,28,29$, and 30 . The mean score of 201 , shown in table 31, was 70 percent of the possible weighted score of 285 . Category VIII, Non-Factor Related Items, ranked sixth amung the nine categories. Item 1, Diagnosing Basic Learning Difficulties, ranked first in the category with 14 strongly agreed and 26 agreed responses. Item 3, Identifying Student Disabilities That Need Referral or Special Remedial Work, ranked second in the category with the highest number of strongly agreed responses (15). I tem 14, Keeping abreast of Developments in Your Own Subject Matter Area, ranked third in the category with the highest number of agreed responses (30). Item 10, Planning Teaching Activities with Other Teachers or Administrators, had the same number of undecided as strongly agreed responses (10). Both item 19, Gearing Instruction to Problem Solving, and item 23, Constructively Using Evaluation in Helping Student Progress, had 26 agreed responses. Item 8, Deciding What Reaching Technique Is Best for a Particular Intended Outcome, ranked last in the category with the highest number of disagreed responses. Category VIII consisted of 12 questionnaire items-- $1,3,4,8,10,14,17,18,19,23,24$, and 41 . The mean score of 197, shown in table 31 , was 69 percent of the possible weighted score of 285 .

Category VI, Developing Personal Self, ranked seventh among the nine categories. Item 31, Developing a Personal Self-Evaluation Method, ranked first in the category with 8 strongly agreed and 25 agreed responses. Item 32, Developing a Broad Acceptance of Self, ranked second in the category. Item 34, Developing a Capacity of 
Accepting Others' Feelings, ranked last in the category with the highest number of disagreed responses (19) and strongly disagreed responses (3). Category VI consisted of three questionnaire items-31,32 , and 33 . The mean score of 187 , shown in table 31 , was 66 percent of the possible weighted score of 285 .

Category IV, Assessment, ranked eighth among the nine cate-

gories. Item 6, Involving Students in Self-Evaluation, ranked first in the category with 6 strongly agreed and 28 agreed responses. Item 40, Developing or Modifying Instructional Procedures to Suit Your Own Strengths, ranked second in the category with the same number of strongly agreed (6), agreed (28), and undecided (10) responses as item 6 which ranked first in the category. Item 5, Establishing Appropriate Performance Standards, ranked last in the category with the highest number of strongly disagreed responses (4). Category IV consisted of 6 questionnaire items--2, 5, 6, 12 , 33 , and 40 . The mean score of 185 , shown in table 31 , was 65 percent of the possible weighted score of 285 . Category VII, Classroom Management, ranked ninth among the nine categories. item 21, Providing for Reinforcement, ranked first in the category with 8 strongly agreed and 22 agreed responses. Item $\vec{i}$, Teacher-Pupil Verbal Interaction, ranked second in the category with the highest number of agreed responses (24). Both of the above items had 10 undecided and 14 disagreed responses. Both item 22, Deciding on Appropriate Pupil Grouping Procedures for Instruction, and item 20, General Presentation of Information and Directions, had 17 agreed and 9 undecided responses. Category VII consisted of 4 questionnaire items--7, 20, 21, and 22. The mean 
score of 173, shown in table 31 , was 61 percent of the possible weighted score of 285 .

Ranked Categories of Teachers Who Taught Both Elementary and Secondary

The description of the categories is presented in ranked order (table 32). Likewise, the description of the items within the categories is also presented in ranked order, according to the responses.

Category IX, Integration of Faith, Learning, and Practice, ranked first among the nine categories. Item 44 , Constructing and Implementing a Christian Witness Program for Students and Teachers Together, ranked first in the category. Item 46, Making Bible Instruction More Applicable to Everyday Life, ranked second in the category with 25 agreed and strongly agreed responses each. Item 45, Transforming Faith into Action--by Vicarious Experience-Developing Christian Values and Attitudes, ranked third in the category also with 25 agreed responses. Item 43, knowing How to Achieve Faith, Learning, and Practice from the Curriculum through Written Objectives and Evaluating Results, ranked last in the category but had the highest number of agreed responses (27) and undecided responses (11). Category IX consisted of 5 questionnaire items- $-42,43,44,45$, and 46 . The mean score of 226 , shown in table 32, was 87 percent of the possible weighted score of 280 . Category II, Developing Pupil Self, ranked second among the nine categories. Item 39, Instilling in the student the wili to Learn on His Own Initiative, ranked first in the category with 21 strongly agreed responses. Item 13, Motivating Students to Learn 
TABLE 32

A SUMMARY OF RANKED CATEGORIES OF LAKE UNION CONFERENCE TEACHERS WHO TEACH BOTH ELEMENTARY AND SECONDARY GRADES

\begin{tabular}{llll}
\hline \multicolumn{1}{c}{ Categories } & $\begin{array}{c}\text { Ranking } \\
\text { Order }\end{array}$ & $\begin{array}{c}\text { Mean of } \\
\text { Weighted } \\
\text { Score* }\end{array}$ & $\begin{array}{c}\text { Percentage } \\
\text { of Possible } \\
\text { Weighted } \\
\text { Score }\end{array}$ \\
\hline IX Integration of Faith, Learning, and Practice & 1 & 226 & 81 \\
II Developing Pupil Self & 2 & 216 & 77 \\
V Discipline & 3 & 208 & 74 \\
III Individualized Instruction & 4 & 207 & 74 \\
VIII Non-factor Related Items & 5 & 201 & 72 \\
IV Assessment & 6 & 201 & 72 \\
VI Developing Personal Self & 7 & 192 & 68 \\
VII Classroom Management & 8 & 191 & 68 \\
\hline
\end{tabular}

*Maximum weighted score for this table was 280 [five times the number of teachers in the group]. 
on Their Own, ranked second in the category. Item 35, Facilitating Pupil Self-Concept and Worth, had the highest agreed responses (31), whereas, item 36, Facilitating Pupil Social Interaction, had the highest disagreed (10) and undecided (12) responses. Category II consisted of 6 questionnaire items--13,35,36, 37, 38, and 39 . The mean score of 216 , shown in table 32, was 77 percent of the possible weighted score of 280 . (56 teachers $\times 5$ ).

Category $V$, Discipline, ranked third among the nine categories. Item 26, Useful Methods of Classroom Discipline and When to Use Them, ranked first in the category with the highest agreed (21) and strongly agreed (19) responses. Item 27, Maintaining Classroom Control without Appearing as an Ogre to the Students, ranked second. Category $V$ consisted of 2 questionnaire items--26 and 27 . The mean score of 208, shown in table 32 , was 74 percent of the possible weighted score of 280 .

Category III, Individualized Instruction, ranked fourth among the nine categories. Item 9, Developing the Use of the Computer in the Classroom, ranked first with the highest number of strongly agreed (18) and undecided responses (13). Item 15, Selectinc and Developing iaterials Activities Appropriate for Individualized Instruction, ranked second in the category. Item 16, Implementing and Supervising Individualized Instruction, ranked third with the highest number of agreed responses (26), while item 11 , Creating Useful Remedial Materials, ranked last with the highest number of disagreed (10) responses. Category III consisted of 4 questionnaire items--9, 11, 15, and 16. The mean score of 207, shown in table 32, was 74 percent of the possible weighted score of 280 . 
Category I, Interpersonal Communication and Administration, ranked fifth among the nine categories. Item 28 , Communicating and Interacting with Parents, ranked first in the category with 17 strongly agreed responses. Item 30, Involving Others in the School Program, and item 25, Knowing Where to Refer Student Problems beyond What Can Be Handled by the Teacher, had an equal number of totalled agreed and strongly agreed responses (38). Item 29, Counseling and Conferring with Students, ranked last in the category with 15 disagree responses. Category I consisted of 4 questionnaire items-$25,28,29$, and 30 . The mean score of 201 , shown in table 32 , was 72 percent of the possible weighted score of 280 .

Category VIII, Non-Factor Realted Items, ranked sixth among the nine categories. Item 1, Diagnosing Basic Learning Difficulties, ranked first in the category with 45 totalled agreed and strongly agreed responses Item 14, Keeping Abreast of Developments in Your Own Subject Matter Area, had the highest number of strongly agreed responses (17) in the category while item 19, Gearing Instruction to Problem Solving, had the highest number of agreed responses (35) for the category. Item 24, Managing Classroom Affairs in Order to Get Maximum Benefit from Supervising, Aids, Tutors, etc., had the same number of disagreed and undecided responses as did item 18 , Utilization of Audiovisual Equipment and Other Mechanical Aids. Item 10, Planning Teaching Activities with Other Teachers or Administrators, had the highest number of disagreed responses (12). Category VIII consisted of 12 questionnaire items--1, 3, 4, 8, 10, $14,17,18,19,23,24$, and 41 . The mean score of 201 , shown in table 32, was 72 percent of the possible weighted score of 280 . 
Category IV, Assessment, ranked seventh among the nine categories. Item 6, Involving Students in Self-Evaluation, ranked first in the category with 26 agreed and 8 strongly agreed responses. Item 5, Establishing Appropriate Performance Standards, ranked second in the category with 8 strongly agreed responses and 16 undecided responses. Item 2, Constructing and Using Tests for Evaluating Academic Progress, item 40, Developing or Modifying Instructional Procedures to Suit Your Own Strengths, and item 12, Evaluating Instruction/Instructional Design, all had an equal number of strongly agreed responses (6); whereas item 40 had equal number of disagree and undecided responses (12). Category IV consisted of 6 questiunnaire items- $-2,5,6,12,33$, and 40 . The mean score of 192, shown in table 32 , was 68 percent of the possible weighted score of 280 .

Category VI, Developing Personal Self, ranked eighth among the nine categories. Item 31, Developing a Personal Self Evaluation Method, ranked first in the category with a total of 30 agreed and strongly agreed resposes. Item 34, Developing a Capacity of Accepting Others' Feelings, ranked second in the category with 26 agreed responses. Item 32, Developing a Broad Acceptance of Self, ranked last in the category with the highest number of strongly agreed (12) and strongly disagreed responses (5). Category $y I$ consisted of 3 questionnaire items--31, 32, and 34 . The mean score of 191, shown in table 32, was 68 percent of the possible weighted score of 280 .

Category VII, Classroom Management, ranked last among the nine categories. Item 7, Teacher-Pupil Verbal Interaction 
ranked first in the category with the highest number of strongly agreed responses (7) and strongly disagreed responses (6). I tem 7 and item 22, Deciding on Appropriate Pupil Grouping Procedures for Instruction, both had equal number of agreed responses (22); whereas item 21, Providing for Reinforcement, ranked second in the category and had the highest number of agreed responses (24). Item 20, General Presentation of Information and Directions, ranked last in the category. Category VII consisted of 4 questionnaire items-$7,20,21$, and 22 . The mean score of 175 , shown in table 32 , was 62 percent of the possible weighted score of 280 .

Ranked Categories of Principals Who Also Served as Teachers

The description of the categories is presented in ranked order (table 33). Likewise, the description of the items within the categories is also presented in ranked order, according to the responses.

Category IX, Integration of Faith, Learning, and Practice, ranked first among the nine categories. Item 44 , Constructing and Implementing a Christian Witness Program for Students and Teachers Together, ranked first in the category with 10 strongly agreed responses. Item 45, Transforming Faith into Action--by Vicatious Experience--Developing Christian Values and Attitudes, ranked second in the category with the highest number of agreed responses (12). Item 46, Making Bible Instruction More Applicable to Everyday Life, item 43, Knowing How to Achieve Faith, Learning, and Practice from the Curriculum through Written Objectives and Evaluating Results, and item 42, Developing a Better Understanding of the 
TABLE 33

A SUMMARY OF RANKED CATEGORIES OF LAKE UNION CONFERENCE PRINCIPALS WHO ALSO SERVE AS TEACHERS

\begin{tabular}{llll}
\hline Categories & $\begin{array}{c}\text { Rean of } \\
\text { Ranking } \\
\text { Order }\end{array}$ & $\begin{array}{c}\text { Weighted } \\
\text { Score }\end{array}$ & $\begin{array}{c}\text { Percentage } \\
\text { of Possible } \\
\text { Weighted } \\
\text { Score }\end{array}$ \\
\hline IX Integration of Faith, Learning, and Practice & 1 & 70 & 83 \\
III Individualized Instruction & 2 & 66 & 77 \\
IV Assessment & 3 & 60 & 70 \\
VIII Non-factor Related Itemis & 4 & 59 & 69 \\
II Developing Pupil Self & 5 & 56 & 66 \\
I Interpersonal Communication and Administration & 6 & 53 & 62 \\
VI Developing Personal Self & 7 & 51 & 60 \\
V Discipline & 8 & 51 & 59 \\
VII Classroom Management & 9 & 47 & 55 \\
\hline
\end{tabular}

*Maxtmum weighted score for this table was 85 [five times the number of teachers in the group]. 
Theory of Integrating Faith, Learning, and Practice and What Makes It Work, all had the same number of agreed responses (7). No principal-teacher strongly disagreed with any of the items in this category. Likewise, there were only two teachers who were undecided with any item of the category. Category IX consisted of 5 questionnaire items- $-42,43,44,45$, and 46 . The mean score of 70, shown in table 33, was 83 percent of the possible weighted score of 85 ( 17 teachers $\times 5)$.

Category III, Individualized Instruction, ranked second among the nine categories. Item 9, Developing the Use of the Computer in the Classroom, ranked first in the category with 12 strongly agreed and 5 agreed responses. No principal teacher strongly disagreed, disagree, or was undecided with this item. Item 15, Selecting and Developing Materials Activities Appropriate for Individualized Instruction, had the highest agreed responses in the category (10). Item 11, Creating Useful Remedial Materials, was the only item in this category with which any principal teacher disagreed. Category III consisted of 4 questionnaire items--9, 11 , 15, and 16 . The mean score of 66 , shown in table 33 , was 77 percent of the possible weighted score of 85 .

Category IV, Assessment, ranked third among the nine categories. Item 2, Constructing and Using Tests for Evaluating Academic Progress, and item 40, Developing or Modifying Instructional Procedures to Suit Your Own Strengths, had the same number of totalled agreed and strongly agreed responses (11). Item 12, Evaluating Instruction/Instructional Design, ranked third in the category with the highest number of strongly agreed responses 
(5). Item 5, Establishing Appropriate Performance Standards, ranked last in the category with the highest number of agreed responses (10). Category IV consisted of 6 questionnaire items-$2,5,6,12,13$, and 40 . The mean score of 60 , shown in table 33 , was 70 percent of the possible weighted score of 85 .

Category VIII, Non-Factor Related Items, ranked fourth among the nine categories. Item 1, Diagnosing Basic Learning Difficulties, ranked first in the category with a total of 15 agreed and strongly agreed responses. Item 3, Identifying Student Disabilities That Need Referral or Special Remedial Work, ranked second in the category. Item 41, Identifying the Gifted and Talented Students, ranked last in the category with 8 disagreed responses. Category VIII consisted of 12 questionnaire items--1, 3, 4, 8, 10, $14,17,18,19,23,24$, and 41 . The mean score of 59 , shown in table 33, was 69 percent of the possible weighted score of 85 . Category II, Developing Pupil Self, ranked fifth among the nine categories. Item 39, Instilling in the Student the will to Learn on His Own Initiative, ranked first in the category with a total of 13 agreed and strongly agreed responses. Item 39, and item 13, Motivating Students to Learn on Their Own, had the same number of agreed responses, as did item 38. Stimulating Growth of Pupil Attitudes and Values, and item 37, Facilitating Development of Pupil Responsibility. Only four principal-teachers strongly disagree with any items of the category. Item 36, Facilitating Pupil Social Interaction, ranked last in the category with 8 disagreed responses. Category II consisted of 6 questionnaire items-$13,35,36,37,38$, and 39 . The mean score of 56 , shown in 
table 33 , was 66 percent of the possible weighted score of 85 .

Category I, Interpersonal Communication and Administration, ranked sixth among the nine categories. Item 30 , Invoiving Others in the School Program, ranked first in the category with a total of 8 agreed and strongly agreed responses. Item 30 , item 28 , Communicating and Interacting with Parents, had the same number of undecided responses (4) as did item 29, Counseling and Conferring with Students, which had the same number of disagreed responses (5). Item 25, Knowing Where to Refer Student Problems beyond What Can Be Handled by the Teacher, ranked last in the category with the highest number of disagreed responses (8) in the category. Category I consisted of 4 questionnaire items--25, 28, 29, and 30 . The mean score of 53, shown in table 33, was 62 percent of the possible weighted score of 85 .

Category VI, Developing Personal Self, ranked seventh among the nine categories. Item 31, Developing a Personal Self-Evaluation Method, ranked first in the category with a total of 9 agree and strongly agreed responses. Item 32, Developing a Broad Acceptance of Self, ranked second in the category. Item 34, Developing a Capacity of Accepting Others' Feelings, ranked last in the category with the highest number of strongly agreed and disagreed responses. Al1 3 items, 31,32 , and 34 , had the same number of strongly agreed responses (2). Category VI consisted of 3 questionnaire items--31, 32, and 34. The mean score of 51 , shown in table 33, was 60 percent of the possible weighted score of 85 . Category $V$, Discipline, ranked eighth among the nine categories. Item 26, Useful Methods of Classroom Discipline and When to Use Them, 
ranked first in the category with item 27, Maintaining Classroom Controi without Appearing as an Ogre to the Students, ranking second. Both items in the category had equal number of totaled agreed and strongly agreed responses (7). Likewise both items had the same number of undecided responses (1). Category $V$ consisted of 2 questionnaire items- -26 and 27 . The mean score of 51 , shown in table 33, was 59 percent of the possible weighted score of 85 .

Category VII, Classroom Management, ranked last among the nine categories. Item 21, Providing for Reinforcement, ranked first in the category with 3 undecided and a total of 6 agreed and strongly agreed responses. Item 22, Deciding on Appropriate Pupil Grouping Procedures for Instruction, ranked second with the same number of undecided, agreed, and strongly agreed responses as item 21. Item 20, General Presentation of Information and Directions, ranked last in the category with a total of 11 strongly disagreed and disagreed responses. Category VII consisted of 4 questionnaire items--7, 20,21, and 22. The mean score of 47, shown in table 33, was 55 percent of the possible weighted score of 85 .

Sumary--Perceived Needs of Teachers with a Combination of Teaching Assignments

Research questions 18 (What are the perceived inservice needs of Lake Union Conference elementary teachers who teach 3 or less grades?), ig (What are the perceived inservice needs of Lake Union Conference elementary teachers who teach more than 3 grades?), 20 (What are the perceived inservice needs of the Lake Union Conference 
teachers who teach elementary and secondary grades?), and 21 (What are the perceived inservice needs of Lake Union Conference principals who also function as teachers?), as posed in chapter III, are addressed in the presentation of the responses of the 4 groups: elementary teachers who had taught three or fewer grades, elementary teachers who had taught more than three grades, teachers who had taught both elementary and secondary, and principals who also assumed the responsibility of teaching. In addition, the above responses were compared to all K-12 teachers of the Lake Union Conference (fig. 7 and table 34 ).

Category IX, Integration of Faith, Learning, and Practice, was identified as the first perceived inservice need by all of the groups (table 34) except the elementary teachers who had taught three or fewer grades. They perceived category $I X$ as the third inservice need, identifying category II, Developing Pupil Self, as the first inservice need; however, the category was ranked first by all the $k-12$ teachers.

Category II, Developing Pupil Self, was identified as the second perceived inservice need by elementary teachers who had taught more than three grades and teachers who had taught both elementary and secondary. Category III, Individualized Instruction, was identified as the second perceived inservice need by the principals who also serve as teachers and elementary teachers who had taught three or fewer grades, whereas category II was ranked second by the $k-12$ teachers.

Category V, Discipline, was identified as the third perceived inservice need by the teachers who had taught both elementary 


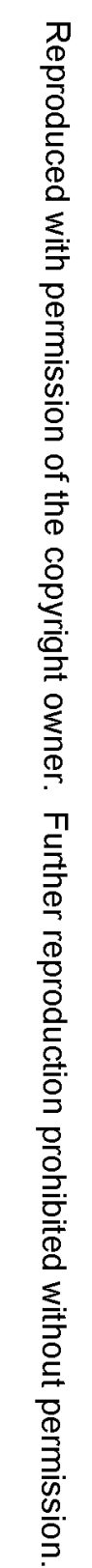

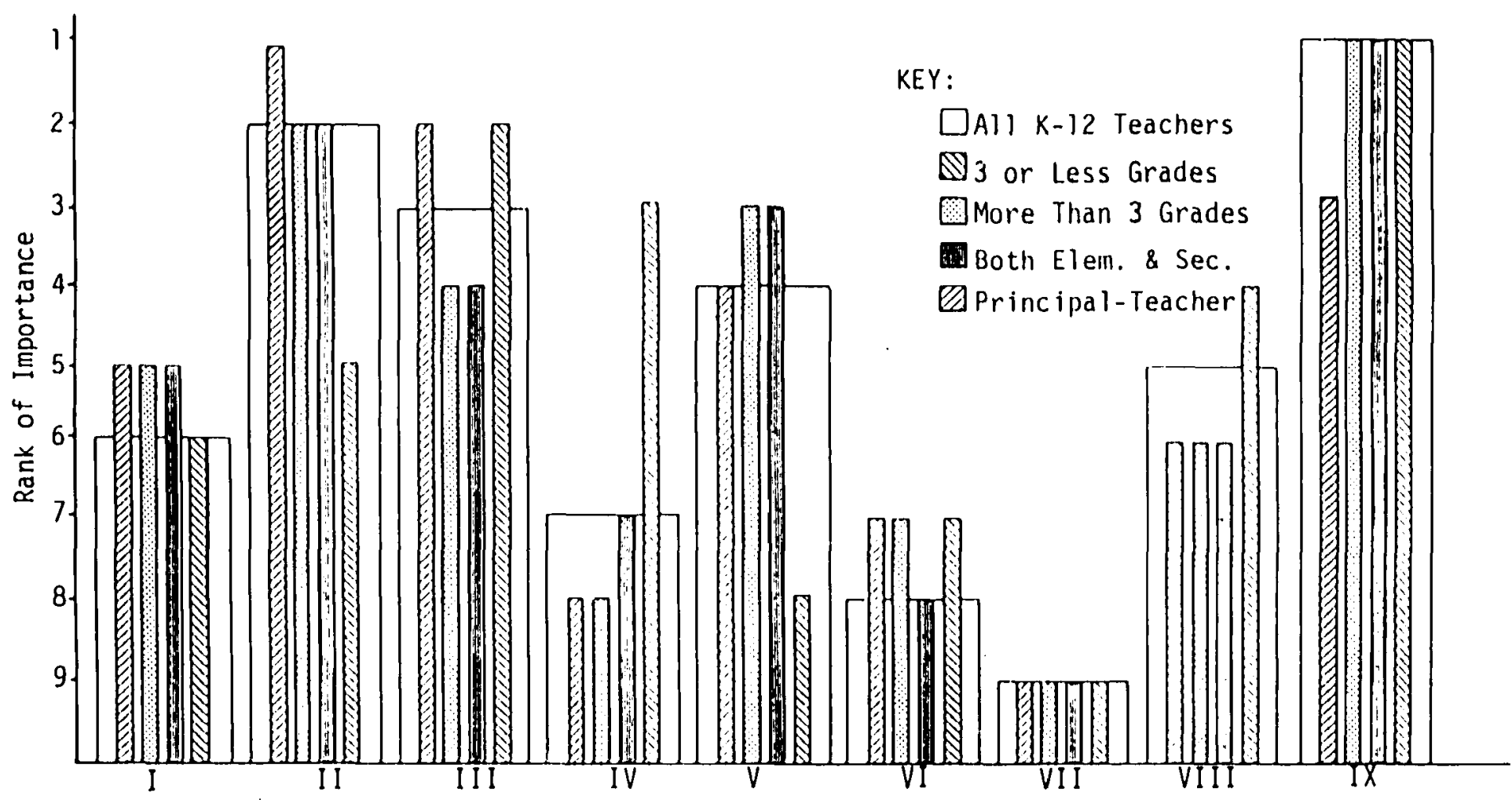

Fig. 7. Comparison of the ranked categories of teachers who had a combination of teaching assignments. 
and secondary and elementary teachers who had taught more than three grades, whereas the principal teachers identified category IV, Assessment, as the third perceived need.

The remaining categories varied in rankings except category VII which was ranked last by all four groups.

TABLE 34

A COMPARISON OF RANKED CATEGORIES OF ALL K-12 TEACHERS AND TEACHERS WITH A COMBINATION OF TEACHING ASSIGNMENTS

\begin{tabular}{lccccccccc}
\hline \multicolumn{1}{c}{$\begin{array}{c}\text { Combination of } \\
\text { Teaching Assignments }\end{array}$} & I & II & III & IV & V V VI & VII & VIII & IX \\
\hline AII K-12 & 6 & 2 & 3 & 7 & 4 & 8 & 9 & 5 & 1 \\
3 or less & 5 & 1 & 2 & 8 & 4 & 7 & 9 & 6 & 3 \\
4 or more & 5 & 2 & 4 & 8 & 3 & 7 & 9 & 6 & 1 \\
$\begin{array}{l}\text { Combined elementary } \\
\text { and secondary }\end{array}$ & 5 & 2 & 4 & 7 & 3 & 8 & 9 & 6 & 1 \\
Principal teacher & 6 & 5 & 2 & 3 & 8 & 7 & 9 & 4 & 1 \\
\hline
\end{tabular}

\section{Summary}

The purpose of the study was to identify the perceived inservice needs of the $K-12$ teachers of the Lake Union Conference. This purpose was achieved through an analysis of the survey instrument Lake Union Conference Inservice Assessment which contained 46 items which were divided unevenly into nine categories. The teachers were anaiyzed as a group, and by subgroups, looking at years of experience and teaching assignment. Their responses were analyzed and ranked by items and categories. Item 46, Making Bible Instruction More Applicable to Everyday Life, ranked first among 
the 46 items. Item 39, Instilling in the Student the Will to Learn on His Own Initiative, ranked second, while item 44 , Constructing and Implementing a Christian Witnessing Program for Students and Teachers Together, ranked third. Category IX, Integration of Faith, Learning, and Practice, ranked first among the nine categories. Category II, Developing Pupil Self, ranked second, while Category III, Individualizing Instruction, ranked third.

Chapter $V$ contains the summary, conclusions, and recommendations. 
CHAPTER $V$

SUMMARY, CONCLUSIONS, AND RECOMMENDATIONS

\section{Summary}

The purpose of this study was to identify the perceived inservice needs of the $k-12$ teachers in the Lake Union Conference of Seventh-day Adventists. The Lake Union Conference of Seventhday Adventists comprises the geographical area of the United States known as Illinois, Indiana, Michigan, and Wisconsin. The population of teachers studied numbered 490 of which 289 (59 percent) responded to the questionnaire. Sixty-three secondary, one hundred thirty-five elementary, fifty-six teachers who teach both elementary and secondary, and seventeen principals who also serve as teachers made up the responding population. The questionnaire used was a modified version of Ingersoll's Teacher Needs Assessment Survey and was appropriately named the "Lake Union Conference Inservice Assessment." The modification of the original Ingersoll instrument consisted of the incorporation of five questions to deal with the concept of Integration of Faith, Learning, and Practice which is seen as a unique component in Seventh-day Adventist schools.

In addition to administering the Ingersoll survey instrument, a thorough study was made of the related literature in order to establish a theoretical base for a critical analysis of the data 
and the recommendations that would result from the research. The findings were then evaluated against twenty-one research questions.

The review of literature covered the following topics:

1. Historical Overview

2. Purposes of Inservice Education

3. Characteristics of Successful and Unsuccessful Programs

4. Delivery Systems

5. Cooperative Programs

6. Planning Strategies

7. Varying Needs of Teachers

The review of the related literature consistently pointed out the team approach for planning effective inservice programs which is collaboration between administrators and teachers in planning inservice programs who will be directly affected by the programs. The basic purpose of inservice education appears to be the improvement of pupil achievement through the modified behavior of the teacher. The primary characteristics of effective inservice education were shown to consist of programs where: (1) teachers were partners in planning, (2) concepts presented were applicable to both teachers and administrators, (3) teachers actively participate in learning experiences, and (4) activities had immediate application to the classroom, combining subject matter with methodology, which often included teacher-made materials.

The kind of programs that worked best were those which modeled skill development in a classroom setting. Planning strategies should take into consideration the (1) site, (2) funds available, (3) time of year, and (4) the needs of the participants. The 
literature revealed that the needs of teachers varied, depending upon their actual teaching assignment and years of experience.

Delivery systems shown to be effective ranged from

(1) workshops, (2) institutes, (3) travel, (4) teacher visitation,

(5) teacher centers, and (6) extension courses.

The desired length of time for any of these programs depended upon the subject matter. The best time for conducting inservice programs appeared to be during school with released time rather than weekends or over vacations.

An analysis of the data gathered by way of the survey questionnaire administered revealed the following results in answer to the twenty-one research questions posed. (Refer to pp. 81 and 82 for the questions)

Question 1. What are the perceived inservice needs of the K-12 Lake Union Conference teachers?

The K-12 teachers chose Category IX, Integration of Faith, Learning, and Practice ( 80 percent of the possible weighted score), as their foremost perceived inservice need, followed by Category II, Pupil Development (77 percent), with Category III, Individualized Instruction ( 74 percent), as their third perceived inservice need. Category V, Discipline (72 percent), was perceived as the fourth need with Category VIII, Non-factor Related Items (71 percent), perceived as the fifth inservice need.

Question 2. What are the perceived inservice needs of the elementary teachers of the Lake Union Conference?

The elementary teachers perceived somewhat the same as the K-12 teachers with Category IX, Integration of Faith, Learning, and 
Practice ( 79 percent of the possible weighted score), as their foremost perceived inservice need followed by Category II, Pupil Development (77 percent), with Category III, Individualized Instruction (75 percent), as their third perceived inservice need. Category V, Discipline (72 percent), was perceived as the fourth need with Category $i$, Interpersonal Communication and Administration ( 71 percent), was perceived as the fifth inservice need. Question 3. What are the perceived inservice needs of the teachers who teach grades $K-2$ ?

The K-2 teachers perceived somewhat the same as the elementary teachers did as a group. Category IX, Integration of Faith, Learning, and Practice (79 percent of the possible weighted score), was perceived as their foremost inservice need followed by Category II, Developing Pupil Self (76 percent), with Category III, Individualized Instruction (73 percent), as their third perceived inservice need. Category V, Discipline (72 percent), was perceived as the fourth need with Category I, Interpersonal Commininication and Administration (72 percent), perceived as the fifth inservice need.

Question 4. What are the perceived inservice needs of the teachers who teach grades $3-5$ ?

The 3-5 teachers chose Category II, Developing Pupil Self (80 percent of the possible weighted score), as their foremost perceived inservice need followed by Category III, Individualized Instruction (78 percent), with Category IX, Integration of Faith, Learning, and Practice (75 percent), as their third perceived inservice need. Category V, Discipline (75 percent), was perceived 
as their fourth need, while Category I, Interpersonal Communication and Administration (72 percent), was perceived as the fifth inservice need.

Question 5. What are the perceived inservice needs of Lake Union Conference el ementary teachers who teach grades 6-8?

The elementary teachers who teach grades 6-8 chose Category IX, Integration of Faith, Learning, and Practice (79 percent of the possible weighted score), as their foremost perceived inservice need followed by Category III, Individualized Instruction (77 percent), with Category II, Developing Pupil Self (77 percent), as their third perceived need. Category $V$, Discipline (72 percent), was perceived as their fourth need while Category VIII, Non-factor Related Items ( 71 percent), was perceived as the fifth inservice need.

Question 6. What are the perceived inservice needs of Lake Union Conference secondary teachers who teach grades 9-12?

The secondary teachers who taught grades 9-12 chose Category IX, Integration of Faith, Learning, and Practice (81 percent of the possible weighted score), as their foremost perceived inservice need followed by Category II, Developing Pupil Self (78 percent), with Category V, Discipline (73 percent), as their third perceived need. Category III, Individualized Instruction (73 percent), was perceived as the fourth need, while Category VIII, Non-factor Related Items (72 percent), was perceived as the fifth inservice need.

Question 7. What are the perceived inservice needs of Lake Union Conference secondary teachers who teach the different disciplines (i.e.. math, Bible, history)? 
The secondary teachers in eleven of the sixteen disciplines chose item 13, Motivating Students to Learn on Their Own, as their first inservice need. Item 14, Keeping Abreast of Developments in Your Own Subject Matter Area, was chosen as the second perceived need by teachers in nine of the sixteen disciplines. Three items which were perceived by the same number of teachers in five of the sixteen disciplines were: item 9, Developing the Use of Computers in the Classroom, item 29, Counseling-Conferring with Students, and item 44, Constructing and Implementing a Christian Witnessing Program for Students and Teachers Alike.

Question 8. What are the perceived inservice needs of Lake Union Conference elementary teachers who have taught $0-5$ years? The elementary teachers with 0-5 years of experience chose Category II, Developing Pupil Self (81 percent of the possible weighted score), as their foremost perceived inservice need followed by Category IX, Integration of Faith, Learning, and Practice (79 percent), with Category V, Discipline (79 percent), as their third perceived inservice need. Category III, Individualized Instruction (77 percent), was perceived as the fourth need while Category I, interpersonal Communication and Administration (73 percent), was perceived as the fifth inservice need.

Question 9. What are the perceived inservice needs of Lake Union Conference elementary teachers who have taught 6-10 years?

The elementary teachers with 6-10 years of experience chose Category IX, Integration of Faith, Learning, and Practice (81 percent of the possible weighted score), as their foremost perceived inservice need followed by Category II, Developing Pupil Self 
(76 percent), with Category III, Individualized Instruction (73 percent), as their third perceived inservice need. Category I, Interpersonal Communication and Administration (73 percent), was perceived as the fourth need, while Category VIII, Non-factor Related Items ( 71 percent), was perceived as the fifth inservice need.

Question 10. What are the perceived inservice needs of Lake Union Conference elementary teachers who have taught 11-15 years?

The elementary teachers with 11-15 years of experience chose Category II, Developing Pupil Self (77 percent of the possible weighted score), as their foremost perceived inservice need followed by Category III, Individualizing Instruction (73 percent), with Category V. Discipline (72 percent), as their third perceived inservice need. Category IX, Integration of Faith, Learning, and Practice (72 percent), was perceived as the fourth need while VIII, Non-factor Related Items (70 percent), was perceived as the fifth inservice need.

Question 11. What are the perceived inservice needs of Lake Union Conference elementary teachers who have taught 16-20 years?

The elementary teachers with 16-20 years of experience chose category IX, Integration of Faith, Learning, and Practice (86 percent of the possible weighted score), as their foremost perceived inservice need followed by Category II, Developing Pupil Self (83 percent), with Category II, Individualized Instruction (78 percent), as their third perceived inservice need. Category $\mathrm{V}$, 
Discipline (76 percent), was perceived as the fourth need while Category I, Interpersonal Cormunication and Administration (73 percent), was perceived as the fifth inservice need.

Question 12. What are the perceived inservice needs of Lake Union Conference elementary teachers who have taught $21+$ years?

The elementary teachers with $21+$ years of experience chose Category IX, Integration of Faith, Learning, and Practice (78 percent of the possible weighted score), as their foremost perceived inservice need followed by Category II, Developing Pupil Self (76 percent), with Category III, Individualized Instruction (76 percent), as their third perceived inservice need. Category VIII, Non-factor Related Items (69 percent), was perceivec as the fourth, while Category VI, Developing Personal Self (68 percent), was perceived as the fifth inservice need.

Question 13. What are the perceived inservice needs of Lake Union Conference secondary teachers who have taught $0-5$ years?

The secondary teachers with $0-5$ years of experience chose Category IX, Integration of Faith, Learning, and Practice (85 percent of the possible weighted score), as their foremost perceived inservice need followed by Category II, Developing Pupil Self ( 84 percent), with Category VI, Developing Personal Self (78 percent), as their third perceived inservice need. Category V, Discipline (77 percent), was perceived as the fourth, while Category VIII, Non-factor Related Items (76 percent), was perceiyed as the fifth inservice need. 
Question 14. What are the perceived inservice needs of Lake Union Conference secondary teachers who have taught $6-10$ years?

The secondary teachers with 6-10 years of experience chose Category IX, Integration of Faith, Learning, and Practice (84 percent of the possible weighted score), as their foremost perceived inservice need followed by Category II, Developing Pupil Self ( 80 percent), with Category IV, Assessment (74 percent), as their third perceived inservice need. Category III, Individualizing Instruction (74 percent), was perceived as their fourth, while Category VIII, Non-factor Related Items (73 percent), was perceived as the fifth inservice need.

Question 15. What are the perceived inservice needs of Lake Union Conference secondary teachers who have taught $11-15$ years?

The secondary teachers with 11-15 years of experience chose Category II, Developing Pupil Self ( 80 percent of the possible weighted score), as their foremost perceived inservice need followed by Category III, Individualized Instruction (79 percent), with Category IX, Integration of Faith, Learning, and Practice (78 percent), as their third perceived inservice need. Category $V$, Discipline (73 percent), was perceived as the fourth, while Category VI, Developing Personal Self (72 percent), was perceived as the fifth inservice need.

Question 16. What are the perceived inservice needs of Lake Union Conference secondary teachers who have taught $16-20$ years?

The secondary teachers with 16-20 years of experience chose Category VIII, Non-factor Related Items (72 percent of the possible weighted score), as their foremost perceived inservice need followed 
by Category IX, Integration of Faith, Learning, and Practice (72 percent), with Category V, Discipline ( 71 percent), as their third perceived inservice need. Category II, Developing Pupil Self ( 71 percent), was perceived as their fourth need, while Category III, Individualizing Instruction (68 percent), was perceived as the fifth inservice need.

Question 17. What are the perceived inservice needs of Lake Union Conference secondary teachers who have taught $21+$ years?

The secondary teachers with $21+$ years of experience chose Category IX, Integration of Faith, Learning, and Practice (86 percent of the possible weighted score), as their foremost perceived inservice need followed by Category V, Discipline (79 percent), with Category II, Developing Pupil Self (78 percent), as their third perceived inservice need. Category VIII, Non-Factor Related Items (72 percent), was perceived as the fourth need, while Category III, Individualizing Instruction (71 percent), was perceived as the fifth inservice need.

Question 18. What are the perceived inservice needs of Lake Union Conference elementary teachers who teach 3 or less grades?

The elementary teachers who taught three or less grades chose Category II, Developing Pupil Self (79 percent of the possible weighted score), as their foremost perceived inservice need followed by Category III, Individualizing Instruction (77 percent), with Category IX, Integration of Faith, Learning, and Practice (77 percent), as their third perceived inservice need. Category $V$, Discipline (73 percent), was perceived as the fourth need while Category I, Interpersonal Communication and Administration ( 71 percent), 
was perceived as the fifth inservice need.

Question 19. What are the perceived inservice needs of Lake Union Conference elementary teachers who teach more than 3 grades?

The elementary teachers who taught more than three grades chose Category IX, Integration of Faith, Training, and Practice (81 percent of the possible weighted score), as their foremost perceived inservice need followed by Category II, Developing Pupil Self (74 percent), with Category V, Discipline (71 percent), as their third perceived inservice need. Category III, Individualized Instruction ( 71 percent), was perceived as the fourth need while Category I, Interpersonal Communication and Administration (70 percent), was perceived as the fifth inservice need.

Question 20. What are the perceived inservice needs of the Lake Union Conference teachers who teach elementary and secondary grades?

The teachers who taught both elementary and secondary grades perceived somewhat the same as the teachers who taught more than three grades, as they chose Category IX, Integration of Faith, Learning, and Practice ( 81 percent of the possible weighted score), as their foremost perceived inservice need followed by Category II, Developing Pupil Self ( 77 percent), with Category $V$, Discipline (74 percent), as their third perceived inservice need. Category III, Individualized Instruction ( 74 percent), was perceived as the fourth need while Category I, Interpersonal Communication and Administration (72 percent), was perceived as the fifth inservice need. 
Question 21. What are the perceived inservice needs of Lake Union Conference principals who also function as teachers?

The principals who also serve as teachers chose Category IX, Integration of Faith, Learning, and Practice (83 percent of the possible weighted score), as their foremost perceived inservice need followed by Category III, Individualized Instruction (77 percent), with Category IV, Assessment (70 percent), as their third perceived inservice need. Category VIII, Non-factor Related Items (69 percent), was perceived as the fourth need while Category II, Developing Pupil Self (66 percent), was perceived as the fifth inservice need.

\section{Conclusions}

A global analysis of the findings of the study revealed a two fold preponderance of evidence. On the one hand, the various categories of teachers show differing needs, dependent on

1. teaching assignment, as well as

2. the number of years of teaching experience. On the other hand again, there seems to be a golden thread running clear through the findings namely, that the majority of teachers have an awareness of needing to know more on how to better integrate the student's faith and learning, how to academically develop their students, and how to individualize instruction.

Starting with the latter conclusion it is not clear whether teachers selected the category of Integration of Faith, Learning, and Practice, as a priority need for reasons of their perception of their role expectation or because they had had so much theory and 
ideology with respect to Integration of Faith, Learning, and Practice at the expense of being exposed to workable models and modes for the Integration of Faith, Learning, and Practice. Since the current Integration of Faith, Learning, and Practice as an identifiable priority emphasized in Adventist Schools is of comparatively recent vintage, it is not clear whether the need to know more about it is not also an indication of the state of the art in that area, namely that it has strangely penetrated the teacher corps in the Lake Union Conference area as an ideology but that it has not come to creative fruition in terms of finding suitable modes of implementation. This kind of problem is not new in the areas of implementing new ideas and findings.

It is also not clear whether the findings of the present study will hold true for other parts of the United States of America. It may be that the very proximity of Andrews University with its strong emphasis on Integration of Faith, Learning, and Practice to the territories of the Lake Union Conference, give the findings a local bias that may not be readily seen in groups of Seventh-day Adventist teachers in other geographical areas of the United States. Further study needs to be undertaken to determine the holding validity of the preeminent hierarchy of teacher inservice needs as found in the Lake Union Conference of Seventh-day Adventists and the implication that might result from such a study.

Very closely related to the apparent strength and hierarchy of need perception of the teachers in the Lake Union Conference of Seventh-day Adventists is the finding that teachers' needs vary 
according to years of experience and the level where teaching takes place in the school system.

The majority of the total respondents indicated their greatest need was integrating religious concepts into the curriculum, making it applicable to everyday situations. In addition, data showed as an important perceived need of the $k-12$ teachers was pupil development. In other words, motivating the student, while at the same time instilling in the student the will to learn on his own initiative. The respondents indicated still another important perceived need was to individualize instruction, using a variety of methods such as computers, remedial materials and methods of implementing instruction.

Elementary teachers who taught grades $K-2$ perceived a greater need for evaluating, assessing and setting performance standards, whereas, the elementary teachers who taught grades 3-5 had a greater perceived need for pupil development, motivating students and facilitating the pupil's self worth, while the teachers who taught grades $6-8$ had a greater perceived need in the areas of personal development and student development. Elementary teachers who had more years of experience (16-20 and 21+) perceived a greater need for personal development than did the elementary teachers with fewer years of experience.

Secondary teachers, on the other hand, with $0-5$ years of experience had a greater perceived inservice need for personal development while the secondary teachers with 6-10 years of experience perceived a greater need for evaluation and assessment techniques. The secondary teacher with 11-15 years of experience 
perceived a greater need for pupil development and individualizing instruction, than integration of religious concepts, whereas, the secondary teacher with $16-20$ years of experience perceived a greater need for effective teaching techniques, dealing with poor attitudes of students, problem solving, and improving instruction, than integrating the religious concepts into the curriculum. Secondary teachers as a group had a greater perceived inservice need for discipline and personal development than elementary teachers, whereas, the elementary teachers had a greater perceived inservice need for individualizing instruction and developing better communication with parents and students.

For the teachers who had a combination of teaching assignments, the principal-teacher had a greater perceived need for assessment and evaluation techniques. Furthermore, they perceived the least need in the area of managing the classroom.

While secondary and elementary teachers showed differences of perceived inservice needs, the teachers who taught more than three grades and other teachers who taught in both elementary and secondary grades had exactly the same perceived inservice needs.

Principals who also taught in the secondary school did not conform to the general pattern of perceived needs other than placing Integration of Faith, Learning, and Practice first. The principals had a strong emphases on assessment and non-factor related items. The non-factor related items were given a higher priority than secondary teachers as a group evidenced.

The fact that teachers do have different priorities in perceived inservice needs do have some strong implications for planning 
inservice programs. In order to plan adequately for effective inservice programs one has to try and assess the reasons for the different priority needs within a group of teachers. If one tried to develop a specific program to meet the specific needs of each teacher one would either have to have too many programs or would run the risk again of just catering to a few teachers. It would seem therefore that a workable approach to planning inservice programs based on a specific needs assessment might reasonably be to; first, determine the pattern of needs priorities among the teachers; second, to evaluate these into categories; third, to plan different inservice programs for different target teacher groups within the greater teacher corps; and finally, to develop a multi-faceted inservice program to cater for the various nuances of perceived needs.

In analyzing the apparent patterns of need priorities as evidenced by the various groups that emerged in this study, it would appear that while all K-12 teachers as a group evidenced a compatible inage of perceived needs, the dissimilarities are highlighted when elementary and secondary teachers are treated as separate groups. In addition, principals or administrators as a group appear to find greater congruence with secondary teachers. The only time that elementary and secondary teachers as two separate groups appear to be very compatible as one group is when elementary teachers who teach more than three grades are placed with secondary teachers who also teach in the elementary school.

The question remains on how to handle the perceived inservice needs of teachers whose needs vary according to the number of years 
of teaching experience. Should teachers who have 10-20 years of teaching experience be placed in a group because of their priority listing of their needs which appear to be somewhat different from the other groupings of teachers under study? Why is it that the teachers with $10-20$ years of teaching experience as a group do not rate the Integration of Faith, Learning, and Practice category as of prime importance? Is this an evidence of teacher burn-out or second-generational institutionalism? Were these teachers trained in non-Adventist institutions where the Integration of Faith, Learning, and Practice did not receive high priority. Could it perhaps be that teachers in that category passed through Seventhday Adventist schools at a time when the emphasis on Integration of Faith, Learning, and Practice was still comparatively dormant? Even the apparent emphasis on student self-development instead of teacher self-development may not point to a selfiessness but simply a perception on the part of the teachers that they are tired of inservice programs and are qualified enough. It could also evidence a perception on the part of the teachers that to help students in this self-development is indeed a part of Integration of Faith, Learning, and Practice at another Christian activity level. Another aspect of this problem is the teachers in the secondary school who feel a desire for self development when they become aware of the greater demands on knowledge and background when dealing with the more mature students or the elementary teachers with more than six years of experience who become aware of the need to be updated. This same phenomena is evidenced among the elementary teachers of grades 6-8. 
None of the above questions were persued in this study but they are referred to here in an attempt to indicate that firm conclusions on the basis of the facts presented would be nothing but simplistic reasoning. To draw conclusions for other Seventh-day Adventist teachers groups in the United States of America on the basis of the findings of this study when definitive answers to the questions raised have not been obtained, would be concluding too much. It can be safely concluded from the research that currently these findings do constitute a reliable basis for planning inservice programs. However, these programs must be flexibie and have provisions for meeting the muiti-faceted perceived needs of the teachers of the Lake Union Conference. Because the findings of this study have given evidence that principal-teachers have different perceived needs, the study gives validity to the research from the literature that inservice programs should not be planned unilaterally by the administrators, but should be a joint and cooperative effort between teachers and administrators.

Because a large percentage of teachers perceive a need for inservice programs that will assist with the implementation of integration of faith, learning, and practice, the universities should examine their curriculum and be sure that the teacher education courses provide adequate experiences that can be used in classroom for the implementation of faith, learning, and practice. This study did not attempt to discover to what extent the current inservice programs of the Lake Union Conference of Seventhday Adventists actually met the perceived inservice needs of its teachers. 
It appears that the instrument designed by Ingersoll contains items in the Non-factor Related category that could be placed in other categories. This may have masked the real category that a teacher might have selected as representing their particular need priority. While this may not change the findings of the study, it might become critical when teachers assist in pinpointing the areas needed for inservice. Perhaps, this highlights the importance of an objective instrument for assessing teachers' perceived needs.

Because a teacher's perceived needs assessment are but one aspect of the whole matter of inservice education, the findings of this study should not be used exclusively for planning inservice programs for the Lake Union Conference of Seventh-day Adventists.

\section{Recommendations}

Based on the findings of the study, the following recommendations are proposed:

1. That the Lake Union Conference use the findings of this study as a basis for planning their future inservice educational programs on the following basis:

(a) Use the findings of this study as one component in their total inservice program planning keeping in mind the need for determining the perceived needs of administration, the constituency, the parents, the students, and the educational fraternity among Adventists and elsewhere, particularly in the region of the Lake Union Conference.

(b) Make their own determination and evaluation of the patterns of need priorities as evidenced among the teachers 
of the Lake Union Conference.

(c) Establish practical inservice educational programs for specific and identified target teacher groups that have been jointly planned by administrators and recognized expert classroom teachers.

(d) Build into the inservice education programs a flexibility that will allow for a broad, multi-faceted program to address the various nuances of the perceived inservice needs of the teachers in the Lake Union Conference.

(e) Construct, upon recommendation of the joint committee, inservice education programs having the elements of the Integration of Faith, Learning, and Practice which would place greater emphasis on awareness, understanding, self-renewal, and personal committment while stressing practical methods of implementation of the integration of faith and learning programs.

2. That similar studies should be conducted in each of the other Union Conferences of North America to discover the specific perceived inservice needs of each Union Conference's teachers and to determine if a general pattern exists among the teachers employed by the Seventh-day Adventist Church of North America.

3. That specific studies should be conducted and instruments developed to discover the exact reason for the Lake Union Conference teachers' perceived need in the area of Integration of Faith, Learning, and Practice.

4. That specific studies should be undertaken and instruments developed to determine why teachers with $11-20$ years of 
teaching experience do not put such a high priority on Integration of Faith, Learning, and Practice.

5. That a specific study be undertaken to determine the nature of the inservice program of the Lake Union Conference over the past five years and to what extent they had been successful in catering to the present perceive inservice needs of teachers in the Lake Union Conference.

6. That Andrews University give study to the matter of Integration of Faith, Learning, and Practice to determine to what extent prospective teachers are exposed to its concepts as well as the modes for successfully implementing an integration of faith and learning programs. Furthermore, that the university try to determine the extent to which it has had success in orienting a prospective teacher to the task that lies ahead in the area of Integration of Faith, Learning, and Practice.

7. That studies be initiated that will assist in further refining Ingersoll's instrument for assessing the perceived inservice needs for teachers in the Seventh-day Adventist schools.

8. That the findings of this study be treated statistically to discover more accurately its verdicts and reliability.

9. That further inservice assessments be conducted which would include the non-teaching principals, assistant superintendents, and administration in an effort to also ascertain the types of inservice programs that may compliment the perceived needs of the teachers. 
A P PENDICES

Reproduced with permission of the copyright owner. Further reproduction prohibited without permission. 
APPENDIX A

LAKE UNION CONFERENCE INSERVICE

ASSESSMENT INSTRUMENT

Reproduced with permission of the copyright owner. Further reproduction prohibited without permission. 


\section{DIRECTIONS:}

Please read each item and decide whether or not it constitutes an area of need for yourself. Each statement defines an area of need. Mark with pencil the degree to which you agree or disagrce with each as an area in which you feel you could use some irairing. If you strongly disagree (SD) that you have a need for skill training in that area mark SD (or column $C$ ): if you disagree with the statement as an area of need, mark (D): if you are uncertain mark (U); if you agree that the item reflects an area in which you need training, mark (A): and if you strongly agree mark (SA).

\section{THERE IS A NEED FOR SKILL TRAINING IN}

1. Diagnosing basic learning difficulties

2. Constructing and using tests for evaluating academic progress

3. Identifying student disabilities that need referral or special remedial work

4. Identifying student attitudes in order to better reiate to problems

5. Establishing appropriate performance standards

6. Involving students in self-evaluation

7. Teacher-pupil verbal interaction

8. Deciding what teaching technique is best for a particular intended outcome

9. Developing the use of the computer in the classroom

10. Planning teaching activities with other teachers or administrators

11. Creating useful remedial materials

12. Evaluating instruction/instructional design

13. Motivating students to learn on their own

14. Keeping abreast of developments in your own subject matter area

15. Selecting and developing materials activities appropriate for individualized instruction

16. Implementing and supervising individualized instruction

17. Using questioning procedures that promote discussion

18. Utilization of audio-visual equipment and other mechanical aids

19. Gearing instruction to problem solving

20. General presentation of information and directions

21. Providing for reinforcement

22. Deciding on appropriate pupil grouping procedures for instruction 
23. Constructively using evaluation in helping student progress

24. Managing classroom affairs in order to get maximum benefit from supervising. aids, tutors, etc.

25. Knowing where to refer student problems beyond what can be handled by the teacher

26. Useful methods of classroom discipline and when to use them

27. Maintaining classroom control without appearing as an ogre to the students

28. Communicating and interacting with parents

29. Counselling and conferring with students

30. Involving others in the school program

31. Developing a personal self evaluation method

32. Developing a broad acceptance of self

33. Selecting and specifying performance goals and objectives

34. Developing a capacity of accepting others' feelings

35. Facilitating pupil self-concept and worth

36. Faciltating pupil social interaction

37. Facilitating development of pupil responsibility

38. Stimulating growth of pupil attitudes and values

39. Instilling in the student the will to learn on his own initiative

40. Developing or modifying instructional procedures to suit your own strengths

41. Identifying the gifted and talented students

42. Developing a better understanding of the theory of integrating faith, learning and practice and what makes it work.

43. Knowing how to achieve faith, learning and practice from the curriculum through written objectives and evaluating results

44. Constructing and implementing a Christian witness program for students and teachers together

45. Transforming faith into action - by vicarious experience - developing Christian values and attitudes

46. Making Bible instruction more applicable to everyday life

If you would like to add additional inservice ideas. please use the back of this page.

23|:

24|ä

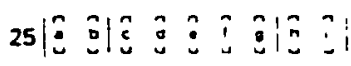

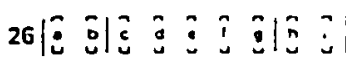

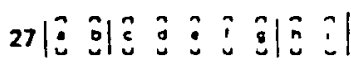

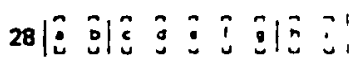

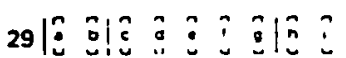

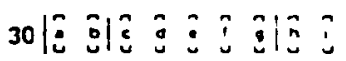

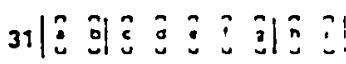

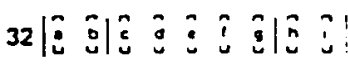

з3|引

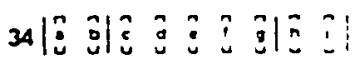

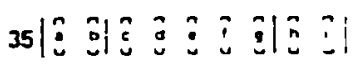

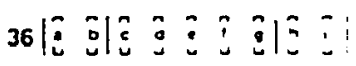

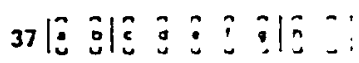

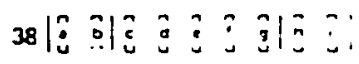

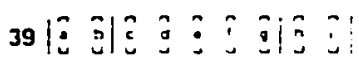

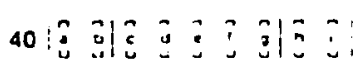

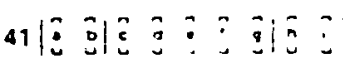

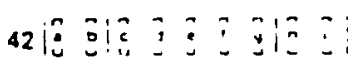

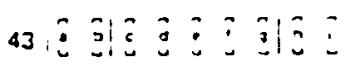

ه4

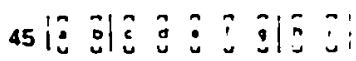

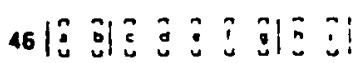




\section{Additional Inservice Ideas}

... Developed at the National Center for the Development of Training Materials in Teacher Education

Permission for modification granted by test designer

INDIANA UNIVERSITY BUREAU OF EDUCATIONAL STUDIES AND TESTING 
APPENDIX B

PERMISSION LETTER FROM LAKE UNION CONFERENCE EDUCATION DEPARTMENT

Reproduced with permission of the copyright owner. Further reproduction prohibited without permission. 
Mrs. Hazel Wright

129 South Maplewood

Berrien Springs, MI 49703

Dear Mrs. Wright:

This is to put in writing the action of the Lake Union educational administrators concerning your research request.

In their meeting on August 16 the available principals and superintendents voted to approve your request. Enclosed is a copy of the signed approval form.

We wish you much success and satisfaction in your research and also in your doctoral dissertation.

Most sincerely,

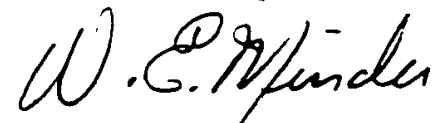

W. E. Minder

Director

OFFICE OF EDUCATIOH

aa

Encl. 
APPENDIX C

INTRODUCTORY LETTER FOR ALL ELEMENTARY

TEACHERS

Reproduced with permission of the copyright owner. Further reproduction prohibited without permission. 
i29 S. Maplewood Drive Berrien Springs, Michigan 49103 August 18,1982

Dear Fellow Teachers,

On: Agust 16, 1982, the Lake Union Conference educational administrators approved my request to conduct research in the Lake Union for my dissertation. The research will be addressing the teachers's perceived inservice needs. Research shows that inservice becomes more effective when the participants and administrators plan the activities together. Thus the enclosed assessment has evolved.

Please take a few minutes to fill out the enclosed instrument as accurately as possible.

May the Lord bless you as you continue to serve Him. Sincerely,

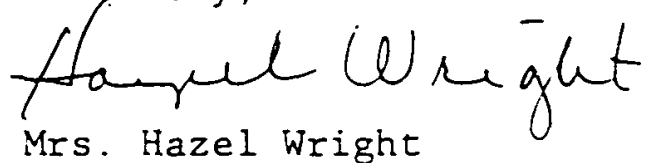

Mrs. Hazel Wright 
APPENDIX D

INTRODUCTORY LETTER TO LAKE REGION

CONFERENCE TEACHERS

Reproduced with permission of the copyright owner. Further reproduction prohibited without permission. 
129 S. Maplewood Drive

Berrien Springs, Michigan 49103

November 8,1982

Dear Fellow Teachers,

On August 16, 1982, the Lake Union Conference educational administrators approved my request to conduct research in the Lake Union for my dissertation. The request is assessing the teacher's perceived inservice needs. Research shows that inservice becomes more effective when the participants and administrators plan the activities together. Thus the enclosed assessment has evolved.

Please take a few minutes to fill out the enclosed instrument and return it in the self-addressed stamped envelope.

May the Lord bless you as you continue to serve Him.

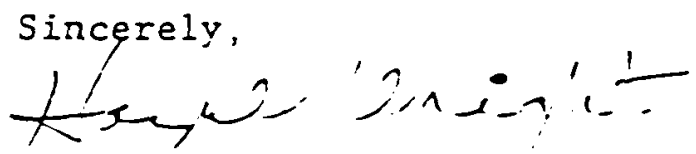

Mrs. Hazel Nright 
APPENDIX E

LETTER TO EDUCATIONAL SUPERINTENDENT OF

THE LAKE REGION CONFERENCE

Reproduced with permission of the copyright owner. Further reproduction prohibited without permission. 
129 South Maplewood Drive

Berrien Springs, Michigan

49103

November 28, 1982

Elder Reginald D. Barnes

Lake Region Conference of Seventh-day Adventist

8517 South State Street

Chicago, Illinois 60619

Dear Elder Barnes:

In accordance with our phone conversation, enclosed please find a copy of the Inservice Assessment instrument, the acceptance of the research request by the Lake Union Educational Committee and the appropriate signed Research Approval form from Andrews University.

To enhance the research being conducted, each educational superintendent has had an active part in distributing and collecting the instrument at their teacher's convention. Since it was not possible for you to distribute the instrument to your teachers at the Lake Region Teacher's Convention, Elder Minder suggested that it would be nice for you to write a letter of support and a letter of encouragement to the teachers to return the completed instrument as soon as possible.

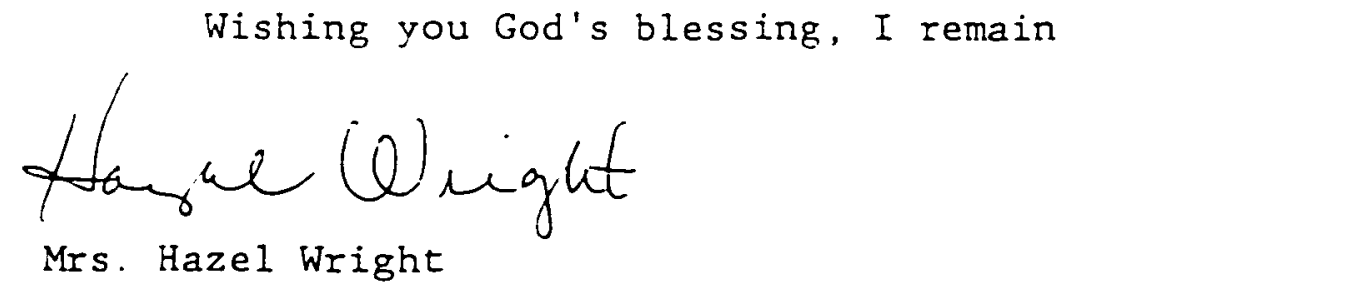




\section{APPENDIX F \\ REMINDER LETTER TO LAKE REGION CONFERENCE TEACHERS}


129 S. Maplewood Drive

Berrien Springs, Michigan 49103

December 5, 1982

Dear Fellow Teachers,

On November 8,1982 , I sent you a research instrument which would assess your perceived inservice needs. Research shows that inservce programs become more effective when the participants and administrators plan the activities together.

Todate, very few of the marked instruments have been returned. Some of you were very prompt, and this is greatly appreciated. If you have not answered the questionnaire, please take a few minutes and put down your responses, and using the self-addressed stamped envelope, send it back to me.

I appreciate your cooperation.

Sincerely,

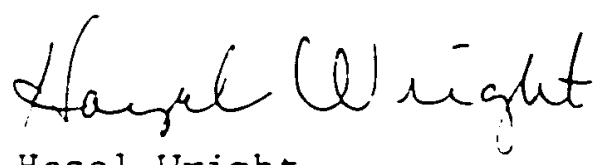

Hazel Wright 


\section{APPENDIX G}

RAW DATA RESPONSES FROM $K-12$ TEACHERS 
RAW DATA RESPONSES FROM K-12 TEACHERS

\begin{tabular}{|c|c|c|c|c|c|c|c|c|}
\hline & & SD & D & U & A & SA & $\begin{array}{l}\text { Rank } \\
\text { Order }\end{array}$ & $\begin{array}{l}\text { Weighted } \\
\text { Score }\end{array}$ \\
\hline 1. & Diagnosing basic learning difficulties & 8 & 27 & 30 & 151 & 73 & 9 & 1121 \\
\hline 2. & $\begin{array}{l}\text { Constructing and using tests for evaluating } \\
\text { academic progress }\end{array}$ & 14 & 74 & 39 & 129 & 32 & 37 & 956 \\
\hline & $\begin{array}{l}\text { Identifying student disabilities that need } \\
\text { referral or special remedial work }\end{array}$ & 7 & 44 & 41 & 130 & 67 & 13 & 1073 \\
\hline & $\begin{array}{l}\text { Identifying student attitudes in order to } \\
\text { better relate to problems }\end{array}$ & 12 & 55 & 46 & 130 & 46 & 28 & 1010 \\
\hline 5. & Establishing appropriate performance standards & 10 & 67 & 65 & 120 & 27 & 38 & 954 \\
\hline 6. & Involving students in self-evaluation & 12 & 49 & 51 & 144 & 33 & 29 & 1004 \\
\hline 7. & Teacher-pupil verbal interaction & 24 & 77 & 52 & 111 & 25 & 44 & 903 \\
\hline & $\begin{array}{l}\text { Deciding what teaching technique is best for } \\
\text { a particular intended outcoine }\end{array}$ & 11 & 58 & 58 & 135 & 27 & 35 & 976 \\
\hline & $\begin{array}{l}\text { Developing the use of the computer in } \\
\text { the classroom }\end{array}$ & 11 & 23 & 58 & 88 & 109 & 8 & 1128 \\
\hline & $\begin{array}{l}\text { Planning teaching activities with other } \\
\text { teachers or administrators }\end{array}$ & 11 & 63 & 52 & 117 & 46 & 31 & 991 \\
\hline 11. & Creating useful remedial materials & 9 & 48 & 42 & 125 & 65 & 17 & 1056 \\
\hline & Evaluating instruction/instructional design & 6 & 55 & 77 & 124 & 27 & 34 & 978 \\
\hline & Motivating students to learn on their own & 6 & 25 & 21 & 131 & 106 & 5 & 1173 \\
\hline & $\begin{array}{l}\text { Keeping abreast of developments in your own } \\
\text { subject matter area }\end{array}$ & 6 & 44 & 33 & 118 & 88 & 10 & 1105 \\
\hline 15. & $\begin{array}{l}\text { Selecting and developing materials activities } \\
\text { appropriate for individualized instruction }\end{array}$ & 8 & 38 & 45 & 142 & 56 & 14 & 1067 \\
\hline
\end{tabular}




DD A Order Score

16. Implementing and supervising individualized instruction

$\begin{array}{rrrrrrr}10 & 39 & 49 & 141 & 50 & 19 & 1049 \\ 14 & 57 & 38 & 127 & 53 & 26 & 1015 \\ 22 & 71 & 45 & 113 & 38 & 42 & 941 \\ 6 & 45 & 45 & 156 & 37 & 20 & 1040 \\ 34 & 106 & 59 & 76 & 14 & 46 & 797 \\ 14 & 69 & 61 & 112 & 33 & 40 & 948 \\ 19 & 85 & 62 & 96 & 27 & 45 & 894 \\ 6 & 39 & 54 & 147 & 43 & 18 & 1049 \\ 11 & 63 & 50 & 119 & 46 & 30 & 993 \\ 18 & 61 & 45 & 111 & 54 & 32 & 989 \\ 15 & 50 & 26 & 122 & 76 & 16 & 1061 \\ 17 & 61 & 31 & 106 & 74 & 21 & 1019\end{array}$




\begin{tabular}{|c|c|c|c|c|c|c|c|c|}
\hline & & SD & D & U & A & SA & $\begin{array}{l}\text { Rank } \\
\text { Order }\end{array}$ & $\begin{array}{l}\text { Weighted } \\
\text { Score }\end{array}$ \\
\hline 28. & Communicating and interacting with parents & 16 & 63 & 29 & 118 & 63 & 25 & 1016 \\
\hline 29 . & Counselling and conferring with students & 13 & 63 & 29 & 130 & 54 & 24 & 1016 \\
\hline 30 . & Involving others in the school program & 10 & 40 & 63 & 143 & 33 & 23 & 1016 \\
\hline 31. & Developing a personal self-evaluation method & 9 & 51 & 56 & 125 & 48 & 22 & 1019 \\
\hline 32. & Developing a broad acceptance of self & 19 & 50 & 63 & 98 & 50 & 36 & 968 \\
\hline 33. & $\begin{array}{l}\text { Selecting and specifying performance goals } \\
\text { and objectives }\end{array}$ & 16 & 61 & 65 & 119 & 28 & 39 & 949 \\
\hline 34. & Developing a capacity of accepting others' fetlings & 19 & 73 & 50 & 109 & 38 & 41 & 941 \\
\hline 35 . & Facilitating pupil self-concept and worth & 9 & 39 & 22 & 150 & 69 & 11 & 1098 \\
\hline 36. & Facilitating pupil social interaction & 10 & 60 & 59 & 127 & 33 & 33 & 980 \\
\hline 37. & Facilitating development of pupil responsibility & 11 & 38 & 37 & 133 & 70 & 12 & 1080 \\
\hline 38. & Stimulating growth of pupil attitudes and values & 8 & 29 & 23 & 146 & 83 & 6 & 1134 \\
\hline 39. & $\begin{array}{l}\text { Instilling in the student the will to learn on } \\
\text { his own initiative }\end{array}$ & 8 & 22 & 20 & 124 & 115 & 2 & 1183 \\
\hline & $\begin{array}{l}\text { Developing or modifying instructional procedures } \\
\text { to suit your own strengths }\end{array}$ & 8 & 53 & 56 & 130 & 42 & 27 & 1012 \\
\hline 41. & Identifying the gifted and talented students & 18 & 68 & 62 & 112 & 29 & 43 & 933 \\
\hline & $\begin{array}{l}\text { Developing a better understanding of the theory } \\
\text { of integrating faith, learning, and practice } \\
\text { and what makes it work }\end{array}$ & 6 & 30 & 39 & 120 & 94 & 7 & 1133 \\
\hline
\end{tabular}


A

$S A$

43. Knowing how to achieve faith, learning and practice from the curriculum through written objectives and evaluating results

44

$44 \quad 127$

67

15

1064

44. Constructing and implementing a Christian witness prograin for students and teachers together

30

125

45. Transforming faith into action--by vicarious experience--developing Christian values and attitudes

46. Making Bible instruction more applicable to everyday 1 ife 
B I B L I OGRAPHY

Reproduced with permission of the copyright owner. Further reproduction prohibited without permission. 


\section{BIBLIOGRAPHY}

Aaron, Ira E. Conducting In-Service Programs in Reading. Newark, DE: International Reading Assn., 1965.

Adams, Myron J. Inservice Teacher Training in Reading. Neward, DE: International Reading Assn., 1964

Akers, George H., and Moon, Robert D. "Integration of Faith, Learning, and Practice." Journal of Adventist Education 42/4,5 (Apri1, May, and Summer 1980):17.

Alexander, William M. Leadership for Improving Instruction. Washington, D.C.: Association for Supervision and Curriculum Development, National Education Association, 1960.

Allen, Owight W. "In-service Training: A Modest Proposal." In Improving In-Service Education: Proposals and Procedures for Change. Edited by Lou is J. Rubin, Boston: Allyn and Bacon, Inc., 1971.

Anderson, William A. "Using Needs Assessment Strategies for Effective Workshops." Journal of Instructional Development 14 (Fall 1980):19.

Arena, J. E. "How to Individualize Inservice Training." Educational Technoiogy, 1974, p. 43.

Austin, W. E., and Morrison, J. A. Conducting. Inservice Programs in Reading. Newark, $D E$ : International Reading Association, 1963.

Berman, A., and Friederwitzer, L. "A Pragmatic Approach to Inservice Education." Action in Teacher Education 3/7 (Winter-Spring, 198i): 51 .

Betz, Loren; Jensen, Darrell; and Zigarmi, Patricia. "South Dakota Teachers View Inservice Education." Phi Delta Kappan 59/7 (1978): 491 .

Bigelow, E. 8. "A Survey, Analys is, and Proposed Program of Inservice Education in Selected School Districts in Six Midwestern States." Unpublished dissertation, University of South Dakota, n.d. 
Bigge, Morris L. Learning Theories for Teachers. New York: Harper and Row, 1964.

Borgealt, Alan J. "Teacher Perceptions of Inservice Education Activities: An Exploratory Study." Ph.D. dissertation, The University of Iowa.

Brictson, Paula. "An Analysis of State Supported Teachers" Centers." Paper presented at American Educational Research Association annual meeting, San Francisco, California, April 1979.

Brimm, Jack L., and Tollett, Daniel. "How Do Teachers Feel about Inservice Educition." Educational Leadership 31 (March 1974):521.

Bronson, George A. "The Appropriateness of Selected Inservice Education Programs as Perceived by Seventh-day Adventist Educators." Ed.D. dissertation, University of Pacific. 1981.

Broudy, H. S. "In-Service Teacher Education--Paradoxes and Potentials." In The In-Service Education of Teachers. Edited by Louis Ruben. Boston: Allyn and Bacon, Ince., 1978.

Bugelski, B. R. The Psychology of Learning. New York: Holt, Rinehart, and Winston, 1956.

Burlingman, Martin. "Their Hearts Were Kung and Gay: The InService Needs of an Inexperienced Teaching Force." In The In-Service Education if Teachers. Edited by Lou is Ruben. Boston: Allyn and Bacon, Inc. 1978.

Burnett, Bernard J. Adoption Guide for Public School Administrators. Washington, D.C.: Office of Education, 1979.

Bush, Robert N. "Curriculum-Proof Teachers: Who Does What to Whom." In Improving In-Service Education: Proposals and Procedures for Change. Edited by Louis J. Rubin. Boston: Allyn and Bacon, Inc., 1971.

Chamberlain, Leo M.; Kindred, Lesl ie W.; and Mickelson, John M. The Teacher and School Organization. Englewood Cliffs, NJ: Prentice-Hall, Inc., 1966.

Ching, Doris M. The Honolulu District Inservice/Pre-Service Teacher. Education Center. Honolulu: University of Hawai 1977.

Cole, Robert $w$. "Inservice Is Not a Verb." Phi Delta Kappan 63/6 (February 1982): 370 . 
Combs, Arthur W.; Avila, Donald L.; and Purkey, William W. Helping Relationships. Boston: Allyn and Bacon, Inc., 1971.

Corno, Lyn, and Clark, Christopher M. "An Aptitude-TreatmentInteraction Approach to In-Service Teacher Traning." In The In-Service Education of Teachers. Edited by Louis Ruben. Boston: Allyn and Bacon, 1978.

Corrigan, Dean. "The Present State of Teacher Education and Needed Reforms." In Futures of Education for Exception.

Published by the National Support Systems Project under a grant from the Division of Personnel Preparation, Bureau of Education for the Handicapped, U.S. Office of Education, Department of Health, Education, and Welfare, 1978.

Cruichshank, D. R.; Kennedy, J. J.; and Myers, B. "Perceived Problems of Secondary School Teachers." Journal of Educational Research 68 (1974):154.

Cruichshank, Donald R.; Lorish, Christopher; and Thompson, Linda. "What We Think We Know about Inservice Education." Journal of Teacher Education 30/1 (January-February 1979): 27 .

Drummond, William H. "Don't Give Up on Inservice, Harry." Journal of Teacher Education 30/1 (January-February 1979): 39 .

Du11, Lloyd $w$. Supervision: School Leadership Handbook. Columbus, $\mathrm{OH}$ : Charles E. Merrill Publishing Company, 1981.

Edelfelt, Roy A. "Inservice Education of Teachers: Priority for Next Decade." Journal of Teacher Education 3 (Fal1 1974):117.

Edmonds, Fred, et. al. "Inservice Teacher Education: A Conceptual Framework." Bulletin of Bureau of Service. Lexington: University of Kentucky, 1966, p. 98.

Edwards, Patsy K. "Teachers' Perceptions of Present Practices . . and Priority of Inservices Education." Unpublished dissertation, The University of Michigan, 1975.

Engel, Martin. "The Continuing Education of Teachers of the Arts." in The In-Service Education of Teachers. Edited by Lou is Ruben. Boston: Allyn and Bacon, Inc. 1978.

English, Fenwick W., and Kauphman, Poger A. Needs Assessment: A Focus for Curriculum Development. Association for Supervision and Curriculum Development, 1975.

Fischier, Abraham S. "Confrontation: Changing Teacher Behavior through Clinical Supervision." In Improving In-Service Education: Proposals and Procedures for Change. Edited by Louis J. Rubin. Boston: ATlyn and Bacon, Inc., 1971. 
Frandson, Phillip E. "Continuing Education for the Professions." In Serving Personal and Community Needs through Adult Education. Edited by Edgar J. Boone, Ronald W. Shearon, Estelle E. White, and Associates. San Francisco: JosseyBass Publishers, 1980.

Furey, Ambrose, J., Jr. "Participation and Personal Growth Keys to Staff Development." In The In-Service Education of Teachers. Edited by Louis Ruben. Boston: AlTyn and Bacon, Inc., 1978.

Goodlad, James, and Klein, M. Francis. Behind the Classroom Door. Worthington, $\mathrm{OH}$ : Charles $A$. jones, 1970.

Goldhammer, Robert; Anderson, Robert H.; Krajewski, Robert J. Clinical Supervision: Special Methods for the Supervision of Teachers. New York: Holt, Rinehart and Winston, 1980.

Grady, Michael P. "A Personalized Competency Reference Model of Teacher Education." St. Louis: Saint Louis University, Saint Louis Public Schools Teachers Corps Program, 1977.

Harris, Ben M. "Inservice Growth--The Essential Requirement." Educational Leadership 24/3 (December 1966):257.

Harris, Ben M., and Bessent, Wailand. In-Service Education: A Guide to Better Practice. Englewood Cliffs, NJ: Prentice Hall Book Co., 1969.

Harris, Ben M.; Bessent, Wailand; and McIntyre, Kenneth E. In-Service Education: A Guide to Better Practice. Englewood Cliffs, WJ: Prentice-Hall, Inc., 1969.

Harrison, Raymond H., and Gowin, Lawrence E. The Elementary in Action. San Francisco: Wadsworth Publishing, Inc., 1958.

Hass, C. Glen. "In-Service Today." In-Service Education for Teachers, supervisors, and Administrators. In Fifty-Sixth Yearbook of the National Society for the Study of Education. Chicago: The University of Chicago Press, 1957.

Hencley, Stephen P.; McCleary, Lloyd E.; and McGrath, J. H. The Elemeritary School Principalsnip. New York: Dodd, Mead \& Company, 1970.

Hentschel, Cloe. "Inservice Education: Does It Make a Difference?" New Direction for Continuing Education 8/3 (1979):89.

Hill, George E., and Potthoff, E. F. Improving Teacher Education through Inter-College Cooperation. Dubuque, IA: Wm. C. Brown Company, 1957. 
Holly, Mary, and Blackman, Charles. "Building a Conceptual Framework for Professional Development." Action in Teacher Education 3/1 (Winter-Spring, 1981):1.

Houston, H. Robert, and Freiberg, $H$. Jerome. "Perpetual Motion, Blindman's Buff, and Inservice Education." Journal of Teacher Education 30/1 (January-February 1979):7.

Howard, William L.; Test, David W.; and Cooke, Nancy L. "Training Inservice Teachers to Use Technology." Tease 4/3 (1981):15.

Hutson, Harry. "Inservice Best Practice: The Learning of General Education." Bloomington: Indiana University, 1980.

Hutson, Harry, and Silvernail, David L. "Inservice Education; A Perception Check." Education Unlimited, February 1980, p. 9.

Ingersol, Gary M. "Assessing Inservice Training Needs through Teacher Responses." Journal of Teacher Education 27/2 (Summer 1976):169.
"Perceived Inservice Needs among Elementary Teachers." School of Education, Indiana University 54/4 (October 1978):3.
James, Barry N. "Client-Centered Approach to Inservice Needs Assessment." Paper presented to the annual meeting of the American Association of Colleges for Teacher Education, Chicago, Illinois, February 27-March 2, 1979.

Johnson, L., and Johnson, M. "The Key to Effective Inservice: Building Teachers Collatoration." The Developer, June 1980 , p. 1 .

Joyce, Bruce, and Showers, Beverly. "Improving Inservice Training: The Message of Research." Educational Leadership 37 (February 1980):379.

Joyce, 3ruce, and Showers, Beverly. "Improving Inservice Training." In Flexibility in Teaching. Edited by Bruce R. Joyce, Clark C. Brown, and Lucy Peck. New York: Longman, Inc., 1981.

Kallenbach, Warren, and Carmichael, Dennis. "The California Teachers Development Project for Systems of individualized Institutions: Individualizing Inservice Education." Speech given before the annual meeting of the American Educational Research Association, Chicago, Illinois, April 1979.

Kaufman, Roger A., and English, Fenwick W. Needs Assessments: A Focus for Curriculum Development. Washington, D.C.: Association for Supervision and Curriculum Development, 1979. 
Kaufman, Roger, and Stakenas, Robert $C$. "Needs Assessment and Holistic Planning." Educational Leadership, May 1981, p. 612.

Kaufman, Robert; Stakenas, Robert G.; Wagner, Jane; and Moyer, Hanna. "Relating Needs Assessment, Program Development, Implementation and Evaluation." Journal of Instructional Development 4/4 (Summer 1981):17.

Kent, James. "The Management of Educational Change Efforts in School Systems." In The Dynamics of Planned Educatinal Change. Edited by Robert E. Herriott and Neal Gross. Berkeley, California, 1979.

Kersh, Bert Y. "Needed: New Ways of Thinking and Acting in Staff Development." Journal of Teacher Education 30/1 (JanuaryFebruary 1979): 44 .

Kimpston, Richard, and Stockton, William S. "Needs Assessment: A Probiem of Priorities." Educational Technology, June 1979 , p. 16.

Knowles, Maicom S. The Modern Practice of Adult Education. New York: Association Press, 1970.

Kuh, George D.; Hutson, Harry; Orbough, Tim; and Byers, Kathy. "Needs Assessment in Regular Inservice." Tease 3/1 $(1980): 16$.

Lance, Jeanne, and Piper, Barbara. "Teachers' Centers Exchanges Directory." National Institute of Education, Washington, D.C., 1980.

Lhota, Robert C. "Multidimensional Model: Adjustment Staff Development." Council of North Central Community and Junior Colleges, 1976.

Lippitt, Ronald, and Fox, Robert. "Development and Maintenance of Effective Classroom Learning." In Improving In-Service Education: Proposals and Procedures for Change. Edited by Louis J. Rubin. Boston: Allyn and Bacon, Inc., 1971.

Lortie, Dan C. School-Teacher A Sociological Study. Chicago: The University of Chicago Press, 1975.

Lueke, William. "Let's Individualize Staff Development." Thrust for Educational Leadership 8/3 (January 1979):17.

Luke, Robert A., et al. "Teachers-Centered Inservice Education Planning and Products." National Institute of Education, Washington, D.C., 1980. 
Mackie, William L., and Gervais, Robert L. "The In-Service Workshop." The Journal of Adventist Education 41/4 (AprilMay 1979 $\longdiv { : 8 - 9 , 4 5 }$

Maloy, Robert $w$, et al. Teacher Centering: A Resource Book for Planning, Developing and Implementing a Teachers ' Center. Massachusetts State Department of Education, Boston, 1980.

Mauth, Leslie J. "Psychology and the In-Service Education Program." National Elementary Principal 41 (February 1962): 15.

McManama, John. An Effective Program for Teacher-Aide Training. West Nyack, NY: Parker Publishing Company, Inc., 1972.

Mill, Alice. "Inservice Education Re-examined." National Elementary Principal 41 (February 1962):52.

Moburg, Lawrence G. In-Service Teacher Training in Reading. Neward, DE: International Reading Association, 1972, p. 42.

Moffit, John C. Inservice Education for Teachers. New York: The Center for Applied Research in Education, Inc., 1963. - In-Service Education for Teachers. Washington, D.C.: Center for Applied Research in Education, Inc., 1965.

Neagley, Ross L., and Evans, N. Dean. Handbook for Effective Supervision of Instruction. Englewood Cliffs, NJ: Prentice-Hall, Inc., 1980.

Ngaiyaye, Morven S. W., and Hanley, Judith Loftus. "What Teachers Want from Inservice Education." North Central Association Quarterly 53/2 (Fall 1978):306.

Oliva, Peter F. Supervision for Today's Schools. New York: Harper and Row, Publishers, 1976.

Olivero, James L. "Helping Teachers Grow Professionally." Educational Leadership $34(1976): 194$.

Otto, Wayne, et al. Inservice Education to Improve Reading Instruction. Newark, DE: International Reading Association, 1973.

Palmer, Teresa M. "In-Service Education: Intrinsic versus Extrinsic Motivation." In The In-Service Education of Teachers. Edited by Louis Ruben. Boston: Allyn and Bacon, Inc., 1978.

Pankratz, Roger S. "Surviving the Inservice Revolution: A Proactive Stance." Journal of Teacher Education 30/1 (January-February 1979):20.

Parkes, Franklin. "Ideas That Shaped American Schools." Phi Delta Kappan 62/5 (January 1981):25. 
Patterson, Jerry L., and Czajkowski, Theodore J. "District Needs Assessment: One Answer to Program Improvement." Phi Delta Kappan 58 (1976):327.

Post, L. M. "A Survey of the Perceptions of Teachers and Supervisory Staff of Inservice Education and Teacher Skill Needs with Implications for a Model of Inservice Education." Doctoral dissertation, Syracuse University, 1975.

Postman, Neil, and Weingartner, Charles. Teaching As a Subversive Activity. New York: Dell Publishing Co., 1969.

Prall, Charles E., and Cushman, C. Leslie. Teacher Education InService. American Council on Education, 1944.

Pitts, R. L. "A Study to Determine Teacher Perceived Needs for Inservice Education in a Selected Urban School District with 1800 Teachers." Doctoral dissertation, Indiana University, 1975.

Roberts, Jack D. "A Hard Look at Quality in In-Service Education." National Elementary Principal 44 (September 1964):17.

Rude, Carolyn R. "Trends and Priorities in Inservice Training." Exceptional Children 45/3 (November 1978): 172 .

Ruben, Louis. Improving Inservice Education: Proposal and Procedures for Change. Boston: Allyn and Bacon, 1971.

Rubin, Louis. "Continuing Professional Education in Perspective." In The In-Service Education of Teachers. Edited by Louis Rubin. Boston: Allyn and Bacon, Inc., 1978.

Sandberg, J. H. "A Moral Dilemma for Teacher Educators." The Educational Forum 42 (1978): 483 .

Schaller, Warren F. "Professional Preparation in Health Education." In School Health Problems. Edited by Glenn B. Knotts and John P. McGovern. Springfield, IL: Charles C. Thomas, 1975.

Schneider, Allen, and Lovett, Charles. "Teacher Centering for Ongoing Inservice Education." Action in Education 2/2 (Spring 1980): 1 .

Schram, C. F. "Improving Inservice for Teachers." Phi Delta Kappan 58 (December 1976):299.

Seldin, Clement A. "Taking Inservice Education off the Back Burner." Phi Delta Kappan 61/4 (December 1979):266.

Sergiovanni, Thomas J., and Elliot, David L. Educational and Organizational Leadership in Elementary Schools. Englewood Cliffs, NJ: Prentice-Hall, Inc., 1975. 
Shuman, R. Baird. "The Training of English Teachers in the $80 \mathrm{s."}$ In Education in the 80s: English. Edited by R. Baird Shuman. Washington, D.C.: National Education Association, 1981 , p. 87.

Smith, 0. S.; Cohen, S. B.; Pearl, A. Teachers for the Real World. Washington, D.C.: American Association of Colleges for Teacher Educators, 1961.

Smith, 0. S.; Otto, Wayne; and Harty, Harold. Inservice Education to Improve Leading Instruction. Newark, $\mathrm{NJ}$ : International Reading Association, 1970.

Sportsman, Michael A. "What's Wrong with Inservice?" Curriculum Review 28 (September 1981):307.

Stephens, Richard, and Thompson, Scott. "Individualizing Inservice Education: The Practitioner." Washington, D.C.: National Association of Secondary Principals, October 1977.

Stone, James C. Teachers for the Disadvantaged. San Francisco: Jossey-Bass, Inc., 1969.

Stoops, Emery; Rafferty, Max; and Johnson, Russell E. Handbook of Educational Adrinistration. Boston: Allyn and Bacon, Inc., 1981 .

Tracey, William R. Designing Training and Development Systems. New York: American Management Association, Inc., 1971.

Trohans, C., and Jackson, R. "The Technical Assistunce Approach to Inservice." Educational Leadership 37 (February 1980):386.

Tyler, Ralph W. Inservice Education of Teachers: A Look at the Past and Future. Edited by Lewis J. Rubin. Boston: Allyn and Bacon, Inc., 1971.

"Accountability and Teacher Performance: Selfdirected and External-directed Professional Improvement." In The In-Service Education of Teachers. Edited by Louis Ruben. Boston: Allyn and Bacon, Inc., 1978.

Wiles, Kimball, and Lovell, John T. Supervision for Better Schools. Englewood Cliffs, $\mathrm{NJ}$ : Prentice-Hall, Inc., 1975.

Wood, Fred H., and Thompson, Steven R. "Guidelines for Better Staff Development." Educational Leadership, February 1980, p. 374.

Yeager, William A. Administration of the Noninstructional Personnel and Services. New York: Harper \& Brothers, 1959.

Zeran, Franklin R. The High School Teacher and His Job. New York: Chartwell House, Inc., 1953. 
VITA

NAME: Hazel R. Garner Wright

DATE AND PLACE OF BIRTH: July 7, 1939, Hinckley, Minnesota

UNDERGRADUATE AND GRADUATE SCHOOLS ATTENDED:

Emmanuel Missionary College, Berrien Springs, Michigan

Andrews University, Berrien Springs, Michigan

Lake Michigan College, Benton Harbor, Michigan

Western Michigan University, Kalamazoo, Michigan

Michigan State University, East Lansing, Michigan

DEGREES AWARDED:

1971 Bachelor of Science

Andrews University

1974 Master of Arts

Andrews University

1983 Doctor of Education

Andrews University

EXPERIENCE:

1959-1962 Secretary, Laboratory Equipment Corporation St. Joseph, Michigan

1965-1968 Secretary, Laboratory Equipment Corporation St. Joseph, Michigan

1971-1973 Physical Education Teacher, Sylvester Elementary School, Berrien Springs, Michigan

1973-1975 Sixth Grade Teacher, Sylvester Elementary School Berrien Springs, Michigan

1975-1983 Reading Speciąlist, Berrien Springs Middle School Berrien Springs, Michigan

1978-1982 Adjunct Instructor, Andrews University Berrien Springs, Michigan

1983

Director, Berrien Springs Middle School Summer School, Berrien Springs, Michigan 